\author{
UNIVERSIDADE DE SÃO PAULO \\ INSTITUTO DE GEOCIÊNCIAS
}

\title{
BASES TÉCNICAS PARA A GESTÃO DE ÁREAS CONTAMINADAS POR SOLVENTES ORGANOCLORADOS EM AQUÍFEROS FRATURADOS
}

\author{
Reginaldo Antonio Bertolo
}

Tese apresentada para obtenção de Título de Livre-Docente junto ao Departamento de Geologia Sedimentar e Ambiental do Instituto de Geociências da Universidade de São Paulo, na área de conhecimento de Hidrogeologia e Gestão de Áreas Contaminadas.

São Paulo

2017 

À CETESB, DAEE, CVS e ao Ministério Público do Estado de São Paulo; Aos amigos Hidrogeólogos de coração:

por consagrar suas missões de proteger e defender a água e a saúde. 


\section{SUMÁRIO}

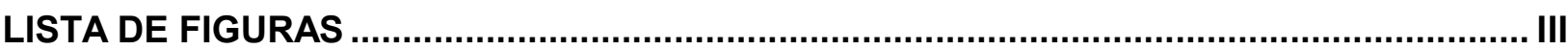

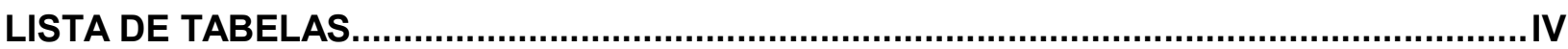

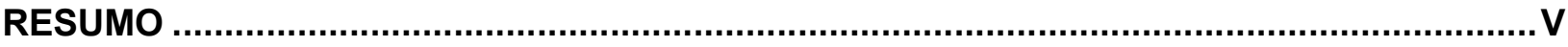

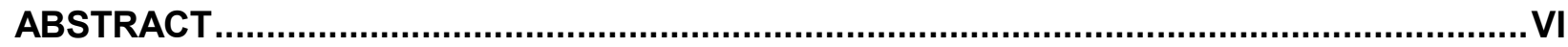

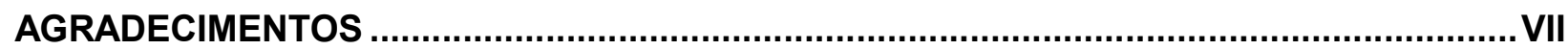

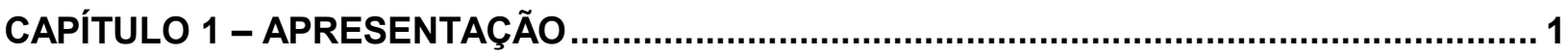

1.1 - Aquíferos Fraturados Contaminados por Solventes Organoclorados ................................................ 1

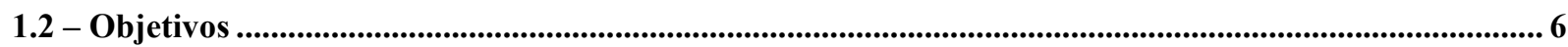

1.3 - Estrutura da Tese ............................................................................................................................................ 7

CAPÍTULO 2 - FUNDAMENTAÇÃO TEÓRICA ......................................................... 8

2.1 - Comportamento Geoquímico dos Hidrocarbonetos Alifáticos Clorados................................................... 8

2.2 - Fluxo de Água e Transporte de Contaminantes em Aquíferos Fraturados............................................ 12

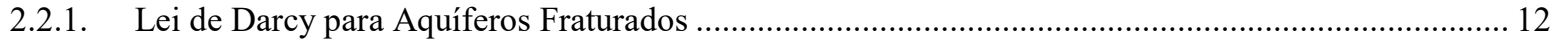

2.2.2. Transporte de Contaminantes em Aquíferos Fraturados......................................................... 15

2.3 - Técnicas de Investigação de Aquíferos Fraturados - Escalas Regional a Local................................... 19

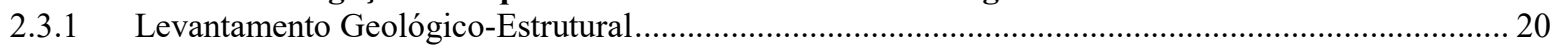

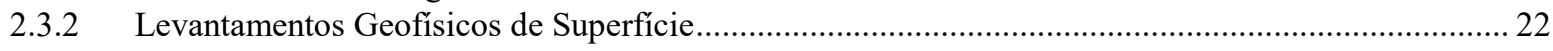

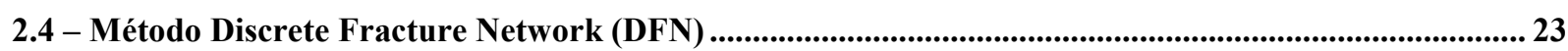

2.4.1 Perfuração e Ensaios em Testemunhos de Sondagem ............................................................ 24

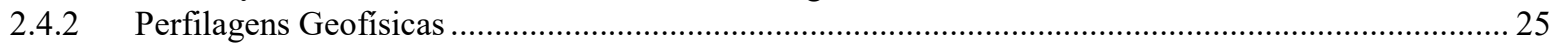

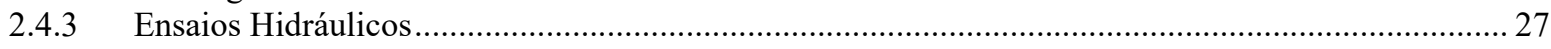

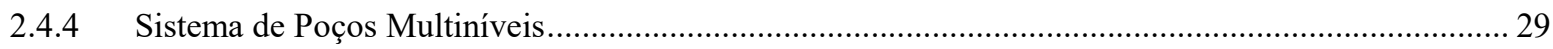

CAPÍTULO 3 - INVESTIGAÇÕES REALIZADAS EM JURUBATUBA, SÃO PAULO.............. 30

3.1 - Modelos Conceituais de Geologia e Hidrogeologia - Escalas Regional a Local.................................... 32

3.2 - Modelos Conceituais de Geologia, Hidrogeologia e de Contaminação - Escala de Superdetalhe........ 35

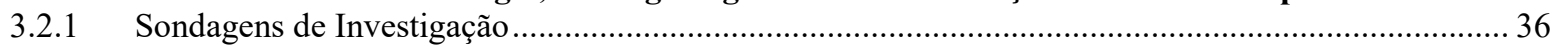

3.2.2. Descrição de testemunhos e coleta de amostras de solo e rocha ................................................... 41

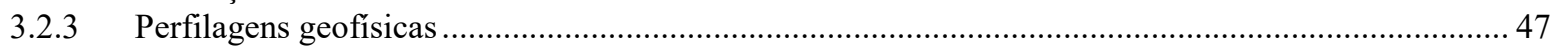

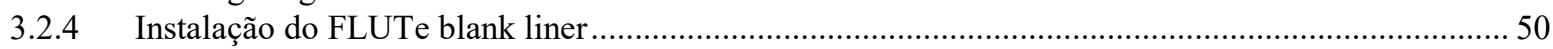

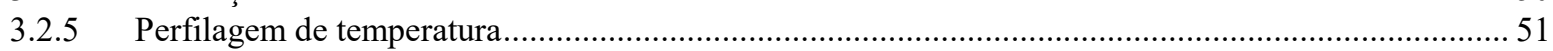

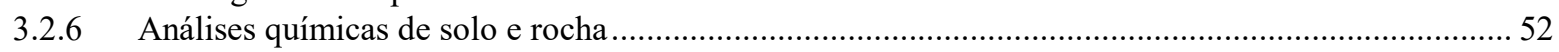

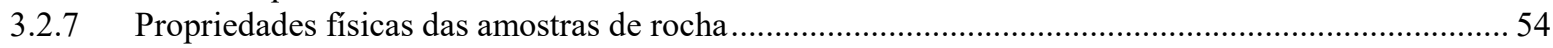

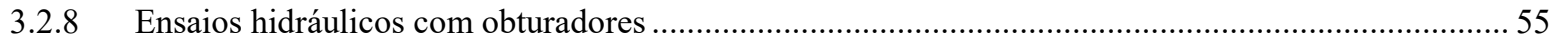

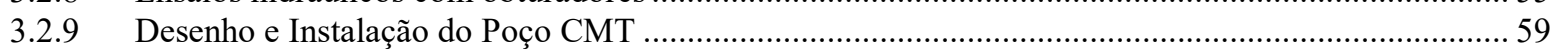

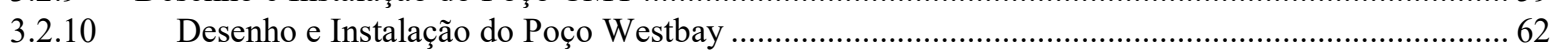


3.2.11 Monitoramento de cargas hidráulicas dos sistemas multiníveis ..............................................67

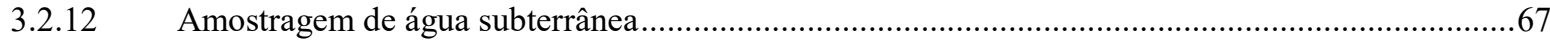

3.2.13 Resultados analíticos de água subterrânea...........................................................................69

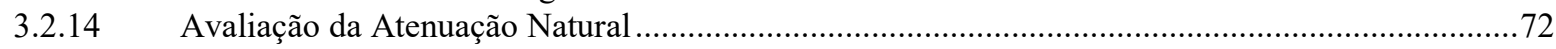

4.1 - Desenvolvimento do Modelo Conceitual Geológico-Estrutural ......................................................................74

4.2 - Desenvolvimento do Modelo Conceitual Hidrogeológico ………........................................................................80

4.3 - Desenvolvimento do Modelo Conceitual da Contaminação ……………………………....................................86

\section{CAPÍTULO 5 - REFLEXÕES SOBRE A GESTÃO DE ÁREAS CONTAMINADAS EM} AQUÍFEROS FRATURADOS ................................................................................... 89

5.1 - Gestão de Áreas Contaminadas por Fontes Individuais...................................................................................90

5.1.1 - Escopo de Investigação e Ações de Intervenção ..........................................................................90

5.1.2 - Exemplo de investigação em aquífero fraturado ..............................................................................98

5.2 - Gestão de Áreas Contaminadas por Fontes Multipontuais ..................................................................99

5.2.1 Fontes Multipontuais de Compostos Organoclorados na RMSP ......................................................99

5.2.2 Gestão Integrada e a Gestão da Informação......................................................................................101

5.2.3 Proposta de Ação de Gestão para a Área do Jurubatuba....................................................................104

CAPÍTULO 6 - CONSIDERAÇÕES FINAIS ................................................................109

REFERÊNCIAS BIBLIOGRÁFICAS .......................................................................111

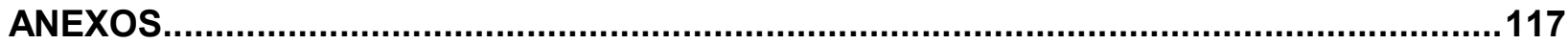




\section{Lista de Figuras}

Figura 1 - Localização de áreas industriais e de poços outorgados na RMSP............................. 3

Figura 2 - Mapa de aquíferos de parte da Região Metropolitana de São Paulo.............................. 3

Figura 3 - Localização de áreas contaminadas por solventes organoclorados na RMSP ..............5

Figura 4 - Modelo conceitual de contaminação de aquífero oriunda de vazamento de DNAPL . 10

Figura 5 - Sequência de degradação dos compostos hidrocarbonetos alifáticos clorados............ 12

Figura 6 - Fratura de comprimento $\mathrm{W}$ e abertura hidráulica e ............................................. 13

Figura 7 - Relação entre abertura hidráulica de uma fratura simples e sua vazão ........................ 14

Figura 8 - Relação entre abertura hidráulica de uma fratura e a velocidade real da água ............ 15

Figura 9 - Modelo conceitual de contaminação em aquífero fraturado com porosidade primária16

Figura 10 - Difusão do contaminante e a posterior ocorrência de difusão reversa ....................... 17

Figura 11 - Acúmulo vertical de DNAPL numa rede de fraturas .............................................. 18

Figura 12 - Relação entre altura mínima de DNAPL e abertura de fratura ................................. 19

Figura 13 - Exemplo de mapa de lineamentos obtido sobre um modelo digital de terreno .........20

Figura 14 - Esquema da amostragem através do método de scanline.....................................21

Figura 15 - Exemplo de resultado de caminhamento elétrico ...................................................22

Figura 16 - Exemplo de respostas sísmicas e suas interpretações geológicas ............................ 23

Figura 17 - Síntese do método Discrete Fracture Network ...................................................24

Figura 18 - Tipos de ensaios hidráulicos realizados com obturadores .....................................28

Figura 19 - Ensaios hidráulicos com FLUTe blank liner..................................................28

Figura 20 - Localização de áreas contaminadas por organoclorados em Jurubatuba, ,................. 31

Figura 21 - Modelo geométrico de fraturas da área do Jurubatuba. ............................................. 34

Figura 22 - Mapa de espessura de sedimentos terciários na área de Jurubatuba .......................... 34

Figura 23 - Mapa de topo do embasamento cristalino na área de Jurubatuba ............................. 35

Figura 24 - Perfil esquemático do furo de sondagem MP-01 ............................................... 37

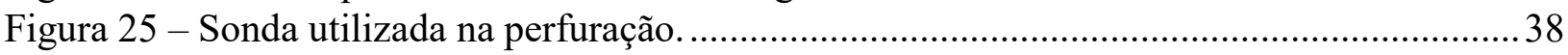

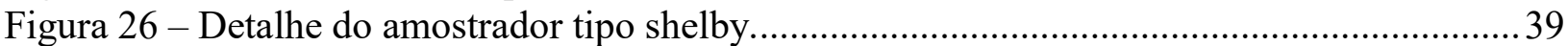

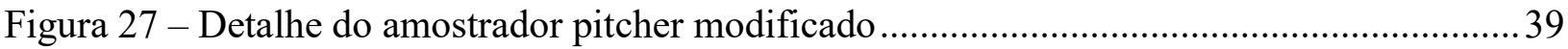

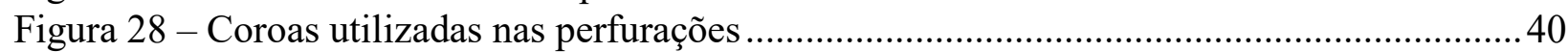

Figura 29 - Perfil de recuperação e RQD da segunda perfuração................................................ 40

Figura 30 - Visão geral das estações de tratamento dos testemunhos ........................................ 41

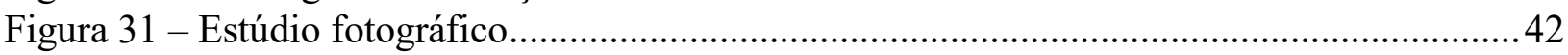

Figura 32 - Estação de descrição litológico-estrutural de testemunhos e coleta de amostras.......42

Figura 33 - Coleta de amostras de solo de alteração e de rocha ................................................ 43

Figura 34 - Triturador (crusher) da terceira estação .................................................................. 43

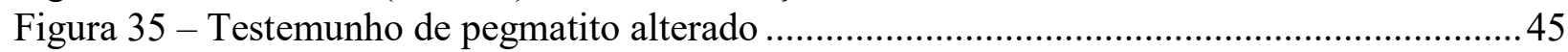

Figura 36 - Testemunho de gnaisse bandado alterado ........................................................... 45

Figura 37 - Testemunho de granada-biotita-feldspato-quartzo-gnaisse fino ............................... 46

Figura 38 - Testemunho de granada-biotita-feldspato-quartzo-gnaisse, bandado ....................... 46

Figura 39 - Testemunho de granada -turmalina-feldspato-quartzo-pegmatito ............................46

Figura 40 - Sondas de perfilagem geofísicas utilizadas: cáliper; imageador OTV eATV ............47

Figura 41 - Resultados das perfilagens ótica, acústica, gama e calibre. ..................................... 49

Figura 42 - Projeção dos polos das fraturas identificadas da sondagem MP-01 ........................ 49

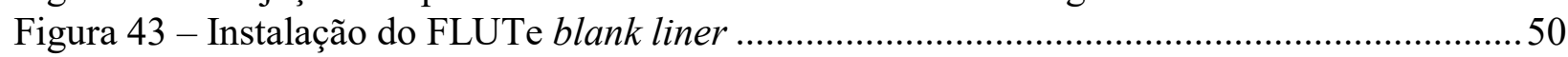

Figura 44 - Dados brutos do perfil ALS ................................................................................ 51

Figura 45 - Resultados das Análises Químicas de solo e rocha (MP-01).................................53

Figura 46 - Resultados das Análises Químicas de solo e rocha - 2 Campanha (MP-01A)........54

Figura 47 - Valores de porosidade total em relação a concentrações de PCE .............................55 
Figura 49 - Sequência dos ensaios nos testes com obturadores. ............................................ 56

Figura 48 - Equipamentos do laboratório móvel de campo ...................................................56

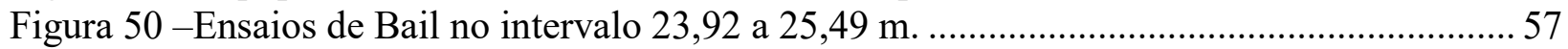

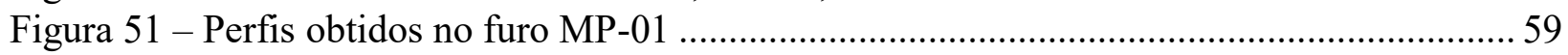

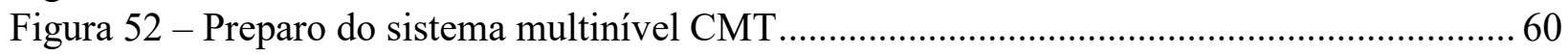

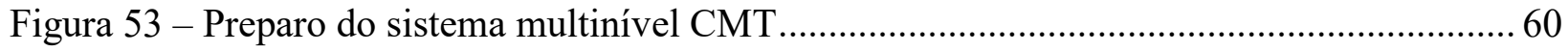

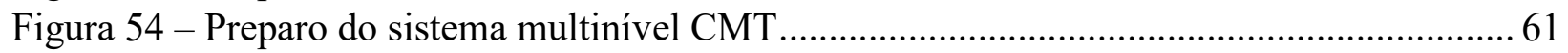

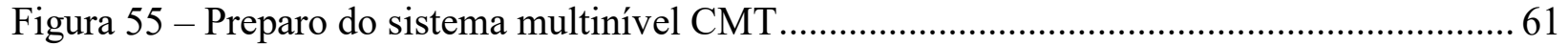

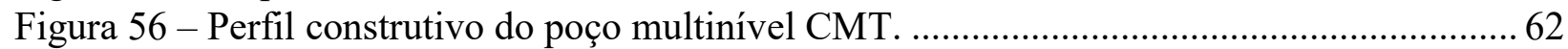

Figura 57 - Remoção do FLUTe blank liner com a green machine .........................................6 63

Figura 58 - Checagem de comprimento e sequência de códigos do sistema Westbay.................63

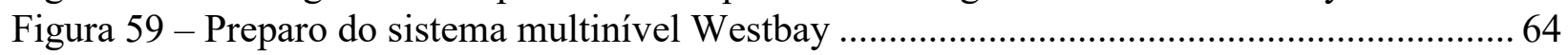

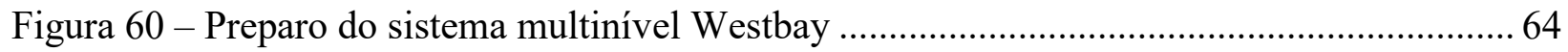

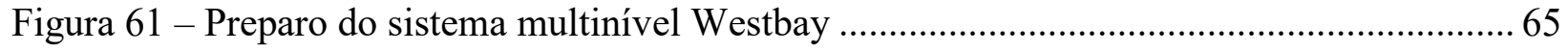

Figura 62 - Perfil construtivo do poço multinível Westbay MP-01......................................... 66

Figura 63 - Monitoramento de cargas hidráulicas dos poços multiníveis CMT e Westbay......... 67

Figura 64 - Monitoramento de cargas hidráulicas dos poços multiníveis CMT e Westbay......... 68

Figura 65 - Fração Molar e VOCs totais: Solo Residual (CMT e poços multiníveis). ................. 70

Figura 66 - Fração Molar e VOCs totais: Embasamento Cristalino (Westbay)........................... 72

Figura 67 - Veio de quartzo imerso em manto de intemperismo ............................................. 77

Figura 68 - Obturadores sendo colocados no interior da perfuração MP-01 ............................... 82

Figura 69 - Classificação de perfis de intemperismo para regiões tropicais $(V a z, 1996)$............ 87

Figura 70 - Possível modelo conceitual em manto de intemperismo e aquífero fraturado ..........87 87

Figura 71 - Etapa 1 de investigação de área contaminada em aquífero fraturado...................... 92

Figura 72 - Ilustração das possíveis locações de sondagens na rocha ....................................... 94

Figura 73 - Etapa 4: instalação de sistemas multiníveis nas sondagens de investigação............. 95

Figura 74 - Possível configuração da contaminação após ações de remediação .......................... 97

Figura 75 - Síntese do modelo conceitual de contaminação da área de Fanti et al (2017).......... 99

Figura 76 - Mapa de clusters de áreas contaminadas por solventes organoclorados na RMSP . 101

Figura 77 - Áreas privadas numa subregião do Jurubatuba................................................... 103

Figura 78 - Estrutura da estratégia de gerenciamento integrado do projeto WELCOME-UE ... 104

Figura 79 - Áreas de controle de poços de captação de água subterrânea em Jurubatuba SP .... 105

\section{Lista de Tabelas}

Tabela 1 - Propriedades físico-químicas de compostos hidrocarbonetos alifáticos clorados......... 9

Tabela 2 - Tipos de reações de biodegradação de compostos organoclorados............................. 11

Tabela 3 - Ensaios realizados com obturadores em cada intervalo. .......................................... 58

Tabela 4 - Características construtivas do poço de monitoramento CMT .................................. 62

Tabela 5 - Parâmetros REDOX e dados de campo (sistema CMT, PM11-A e PM-11B)............ 69

Tabela 6 - Parâmetros REDOX e dados de campo - Poço Westbay ........................................ 71

Tabela 7 - Resultados das análises de etenos clorados de água subterrânea ............................... 71 


\section{Resumo}

As áreas contaminadas por solventes organoclorados em aquíferos fraturados representam um grande desafio para a sua gestão, pois combinam a ocorrência de uma classe de contaminantes de elevado potencial de espalhamento, toxicidade e de complexo mecanismo de degradação, com um meio hidrogeológico também complexo, heterogêneo e anisotrópico, de difícil caracterização. Esta combinação é de ocorrência comum em áreas industriais da Região Metropolitana de São Paulo (RMSP) e arredores, onde outros fatores podem agravar as condições ambientais, como a existência de múltiplas fontes de contaminação e de receptores humanos, representados por usuários de poços profundos.

Dado que são raras as investigações de áreas contaminadas em aquíferos fraturados, este trabalho objetivou contribuir com elementos para propor as bases técnicas para a gestão de áreas contaminadas por compostos organoclorados neste contexto. Assim, técnicas e equipamentos de investigação foram testados e avaliados nos últimos anos, e reflexões sobre a forma de se abordar o gerenciamento de áreas contaminadas por fontes individuais e multipontuais foram efetuadas, tendo o caso da região de Jurubatuba como laboratório.

As técnicas testadas consideradas mais relevantes de serem aplicadas em investigações regulares de áreas contaminadas são: (i) mapeamento geológico-estrutural em afloramentos, (ii) perfurações no manto de intemperismo e na rocha com recuperação contínua de testemunhos, (iii) perfilagens geofísicas em perfurações e poços profundos, (iv) perfilagens com medidores de fluxo, $(v)$ impermeabilização temporária de perfurações, com lonas impermeáveis ou com obturadores, ( $v i$ ) ensaios hidráulicos e coleta de amostras de água com obturadores, (vii) instalação de sistemas multiníveis no manto de intemperismo e na rocha fraturada, (viii) análises físicas e químicas em testemunhos, e (ix) o monitoramento da qualidade química, isotópica e bacteriológica da água subterrânea dos sistemas multiníveis instalados.

Para o gerenciamento de áreas contaminadas complexas por fontes multipontuais, que apresenta potencial de existência em várias localidades da RMSP, destaca-se a necessidade ( $i$ ) de se proceder a realização de projetos liderados pelo Poder Público que visem a gestão ambiental integrada destas áreas; (ii) de se desenvolver uma base de dados em sistema geográfico de informações para guiar e planejar as ações de gestão baseadas em riscos ambientais; (iii) de se proceder investigações e ações de intervenção coordenadas nos aquíferos raso e profundo; e (iv) proceder o desenvolvimento de novas tecnologias nacionais para a investigação e monitoramento de áreas contaminadas. 


\begin{abstract}
The contaminated areas by chlorinated solvents in fractured aquifers represent a great challenge for their environmental management, since they combine the occurrence of a class of contaminants with high potential for spreading, high toxicity and a complex mechanism of degradation, with a complex, heterogeneous and anisotropic hydrogeological environment. This combination is common in industrial areas of the Metropolitan Region of São Paulo and surroundings, where other factors can worsen environmental conditions, such as the existence of multiple sources of contamination and many human receptors, represented by users of deep supply wells.
\end{abstract}

Since investigations of contaminated areas in fractured aquifers are rare, this work aimed to contribute with elements to propose the technical bases for the management of contaminated areas by chlorinated solvents in this context. Thus, techniques and equipment of site investigations have been tested and evaluated in recent years, and reflections on how to deal with the management of contaminated areas by individual and multipoint sources were carried out, being the Jurubatuba region in São Paulo city the laboratory for that.

The techniques that are considered most relevant to be applied in regular investigations of contaminated areas are: (i) geological-structural mapping of outcrops, (ii) drilling boreholes along the bedrock with the recovery of continuous coreholes, (iii) geophysical logging in the boreholes and existing deep supply wells, (iv) flowmeter logging in the boreholes, (v) instalation of liners or temporary straddle packers in the boreholes, (vi) discrete hydraulic tests and groundwater sampling with straddle packers, (vii) installation of multilevel systems in the shallow weathered aquifer and in the fractured bedrock aquifer, (viii) physical and chemical analyzes of the corehole samples, and (ix) the monitoring of the chemical, isotopic and bacteriological quality of the groundwater from the installed multilevel systems.

Regarding the complex contaminated areas by multipoint sources, which presents potential of existence in several locations in the RMSP, the following management activities are important: (i) accomplishment of projects that aim at the integrated environmental management of these areas; (ii) development of a geographic information system database to guide and plan management actions based on environmental risk assessments; (iii) investigations and coordinated remediation actions of shallow weathered and deep fractured aquifers; and (iv) development of national technologies for the investigation and monitoring of contaminated areas, replacing those that are difficult to obtain from abroad. 


\section{Agradecimentos}

Sem estas instituições, não haveria projeto. Agradeço, portanto, pela valorosa contribuição e confiança:

- Ao Instituto de Geociências da USP, ao Departamento de Geologia Sedimentar e Ambiental e ao Centro de Pesquisas de Águas Subterrâneas (CEPAS), minhas casas;

- À FINEP (convênio 01.10.0808.00), FAPESP (processos 2013/21795-1) e Ministério Público do Estado de São Paulo (através do ex-Promotor, Dr. José Eduardo Lutti e do Promotor Dr. Marcos Stefani), pelos preciosos apoios financeiros para as investigações e para a aquisição de equipamentos. À FUSP, na parceria da administração dos recursos de projetos. À FAPESP (processo 2013/21795-1) e ao CNPq, respectivamente, pelas concessões de bolsas de estágio à pesquisa no exterior e de produtividade à pesquisa;

- Ao grupo de pesquisa G360 da Universidade de Guelph (Canadá), na pessoa da pesquisadora Beth Parker, pela contribuição, colaboração e por receber os membros brasileiros do projeto em seu centro de pesquisa.

- À CETESB, pela confiança em ceder informações para a montagem do piloto da base de dados do sistema geográfico de informações;

- Às empresas da região do Jurubatuba: Ergomat, Shopping SP Market, Viena, MWM e SENAC, por ceder acesso às suas áreas para obtenção de dados valiosos para o projeto; às empresas Engesolos, Analytical Technology, Westbay pela parceria no fornecimento de serviços e equipamentos; às empresas de consultoria ambiental Servmar, Tetratech e Essencis, por ceder o tempo de colaboradores para a execução do projeto;

\section{Sem estas pessoas, também não haveria projeto. Nem graça:}

- Aos funcionários do CEPAS: Fernando e Paulinho, pelos apoios de campo; Eli e Lúcia Helena, pelas análises de água e, especialmente, Sônia Candeo, pela dedicação no suporte administrativo dos projetos;

- Às funcionárias da FUSP, Isabelle e Janis, pela parceria na administração dos projetos;

- Às professoras Veridiana Martins, Christine Bourotte e Alexandra Suhogusoff pela companhia e suporte para tornar possível a realização do projeto e desta tese; ao Prof. Caetano Juliani, pelas demandas de chefia de departamento.

- Aos pesquisadores da Universidade de Guelph, Beth Parker, Pete Pehme, Patrick Quinn, Ryan Kroeker pelas participações na produção e interpretação de dados do projeto;

- Ao Carlos Birelli do IPT, pela parceria na produção de dados de perfilagens geofísicas; 
- Ao professor René Schneider (POLI-USP), pela coorientação da mestranda Sílvia;

- Aos alunos de graduação e iniciação científica: César Miyata, Fabio Sartório, Milton Andrade Neto, Denis Kamio, Raphael Salaroli, Vitor Cavenaghi, Ricardo Saito, Marcos Akira Ueda, Bruno Consentino, pelos trabalhos de campo e produção de dados de qualidade inestimável para o projeto.

\section{A estas pessoas, amigos Hidrogeólogos de coração, seres aquáticos, dedico este} trabalho:

- Paulo Lojkasek Lima: intuição e precisão; o fogo Vermelho que incitou o nascimento do projeto; Marcos Bolognini Barbosa: iniciativa, habilidade, concretização; Daphne Pino: concentração e excelência; Sílvia Ferreira: dedicação, suavidade e realização; Bruna Fiúme: graça e perspicácia; José Ângelo Silva: confiança e foco; Lucas Ribeiro: visão e liderança; Aline Fanti: compromisso e liberdade, Carlos Maldaner: assertividade e generosidade; Juliana Camillo e Paulo Casado: bem-querer, segurança, competência. Vocês me ensinam mais do que eu a vocês. Sinto-me honrado de me servir de base para fazer a Água viver em vocês. Obrigado!

- Sérgio Barbosa, pela sua sabedoria e entusiasmo de menino.

- Ingo Wahnfried, por começar o assunto de fraturados e continuar conosco, mesmo longe, sobre uma "pequena" bacia sedimentar.

- Ramon Aravena, padrinho do projeto e de praticamente todo mundo daqui.

- Rodrigo Araújo Cunha, pela liderança no desenvolvimento das instituições de gerenciamento de áreas contaminadas, pela visão e dedicação de trabalhar pela educação e pelo bem comum. Que força admirável!

- Amélia Fernandes, um ser pra quem meu sorriso brota espontaneamente. Tão sensível, que fala com as Rochas Fraturadas! Fala, portanto, com a Água também. Madrinha!

- Ricardo Hirata, sempre referência, grande inspirador, apoiador, compartilhador, a excelência na arte de mostrar o bem comum. Uma fonte de Água generosa.

A estas pessoas, eternamente grato, meu amor:

- Pedro, Helena e Celina, pela vida;

- Rhauna, continuando a luz presente em todos os momentos e caminhos;

- Nilo e Lia, meus filhos. 


\section{Capítulo 1 - Apresentação}

\section{1 - Aquíferos Fraturados Contaminados por Solventes Organoclorados}

Todas as áreas contaminadas apresentam características que tornam complexas as tarefas de determinação, em subsuperfície, de suas dimensões e intensidades e, em especial, de seu saneamento. Em geral, a existência associada de contaminantes de elevada toxicidade com a heterogeneidade geológica e hidrogeológica, que é regra prática em todos os locais, faz obrigatória a aplicação de grande quantidade de recursos para se determinar a localização da contaminação em subsuperfície, sua massa, suas características de deslocamento e transformações, situações essas que são fundamentais de se determinar para a definição da necessidade de se remediar, quais técnicas utilizar e até quando e quanto remediar.

Mesmo passados mais de três décadas de desenvolvimento contínuo de técnicas cada vez mais sofisticadas de engenharia de remediação, o que ainda se vê e o que se confirma é que é praticamente impossível restabelecer as condições originais de qualidade do solo e da água subterrânea numa área contaminada por substâncias de elevada toxicidade dentro de um prazo razoável, por mais simples que seja o modelo conceitual geológico do local. O mais notável ao longo deste tempo, entretanto, foi o desenvolvimento da abordagem de avaliação de risco para a gestão da área contaminada, que viabiliza o uso seguro de um local previamente contaminado através da aplicação combinada de ações de remediação, de contenção física, de obras de engenharia e de controle institucional. Tal abordagem vem sendo aplicada com sucesso em vários locais do mundo e também no Estado de São Paulo.

Cerca de $80 \%$ dos mais de cinco mil casos registrados de áreas contaminadas no Estado de São Paulo estão associados com a ocorrência de hidrocarbonetos de petróleo como contaminante (CETESB, 2015). Em geral, as misturas de derivados de petróleo (como a gasolina e diesel) são menos densas que a água e apresentam mecanismos de biodegradabilidade mais simples e rápidos que outras substâncias orgânicas sintéticas. Assim sendo, os casos de contaminação envolvendo hidrocarbonetos de petróleo, também em geral, tendem a ocorrer em porções mais rasas e de porosidade primária dos aquíferos, formando plumas de contaminação relativamente menores, inclusive por conta da maior velocidade relativa de atenuação dos contaminantes.

As substâncias que compreendem os solventes organoclorados, em especial os etenos, etanos e metano clorados, correspondem a contaminantes bastante comuns em ambientes 
industriais em todo o mundo (Pankow \& Cherry, 1996). O potencial de contaminação desta família de substâncias reside nas suas características de elevada toxicidade, baixa solubilidade, densidade mais elevada que a da água e mecanismos de degradação complexos, que fazem gerar compostos filhos muitas vezes mais tóxicos que o composto original. Portanto, normalmente, os casos de contaminação envolvendo solventes organoclorados tendem a comprometer a qualidade de um maior volume relativo de aquífero, especialmente pela possibilidade da contaminação penetrar mais profundamente no seu interior.

Os casos conhecidos de áreas contaminadas em ambiente industrial representam apenas 17\% do total e aqueles envolvendo solventes organoclorados, apenas cerca de 7,5\% (CETESB, 2015). Entretanto, em paralelo ao maior potencial de contaminação proporcionado por estas substâncias, sabe-se que estes números encontram-se subdimensionados, pois a quantidade de empreendimentos industriais existentes no Estado de São Paulo (cerca de 137000) é muito maior que o número de postos de combustíveis (8750) (Cunha, 2017). Há, portanto, um potencial expressivo de existência de casos ainda desconhecidos de áreas contaminadas em ambientes industriais envolvendo compostos organoclorados. O processo de gerenciamento de áreas contaminadas privilegiou, até o momento, a descoberta e a gestão de casos em postos de combustíveis, porém, com a nova orientação do órgão ambiental paulista, dada pela Decisão de Diretoria 38/2017 (CETESB, 2017), há uma clara tendência de descoberta de novos casos de áreas contaminadas em áreas industriais no futuro próximo, incluindo aqueles relacionados com solventes organoclorados.

Considerando que os casos de contaminação envolvendo solventes organoclorados são potencialmente mais danosos e perigosos ao ambiente, eles ganham ainda maior complexidade quando ocorrem em aquíferos fraturados, dada a mais elevada heterogeneidade e anisotropia destes aquíferos, o que torna mais difícil a determinação e previsão dos caminhos que os contaminantes farão em subsuperfície através das fraturas. Ocorre, entretanto, que grande parte dos distritos industriais instalados no Estado de São Paulo e na região centro-sul do Brasil situase em contexto geológico de rochas fraturadas do embasamento cristalino pré-cambriano, ou mesmo sobre bacias sedimentares cenozóicas pouco espessas. O caso da Região Metropolitana de São Paulo (RMSP) indica que boa parte das áreas industriais (Figura 1) situa-se em contexto de aquífero cristalino ou junto às planícies aluvionares dos principais rios, que geralmente apresentam camadas sedimentares pouco espessas sobre o embasamento cristalino (Figura 2). 


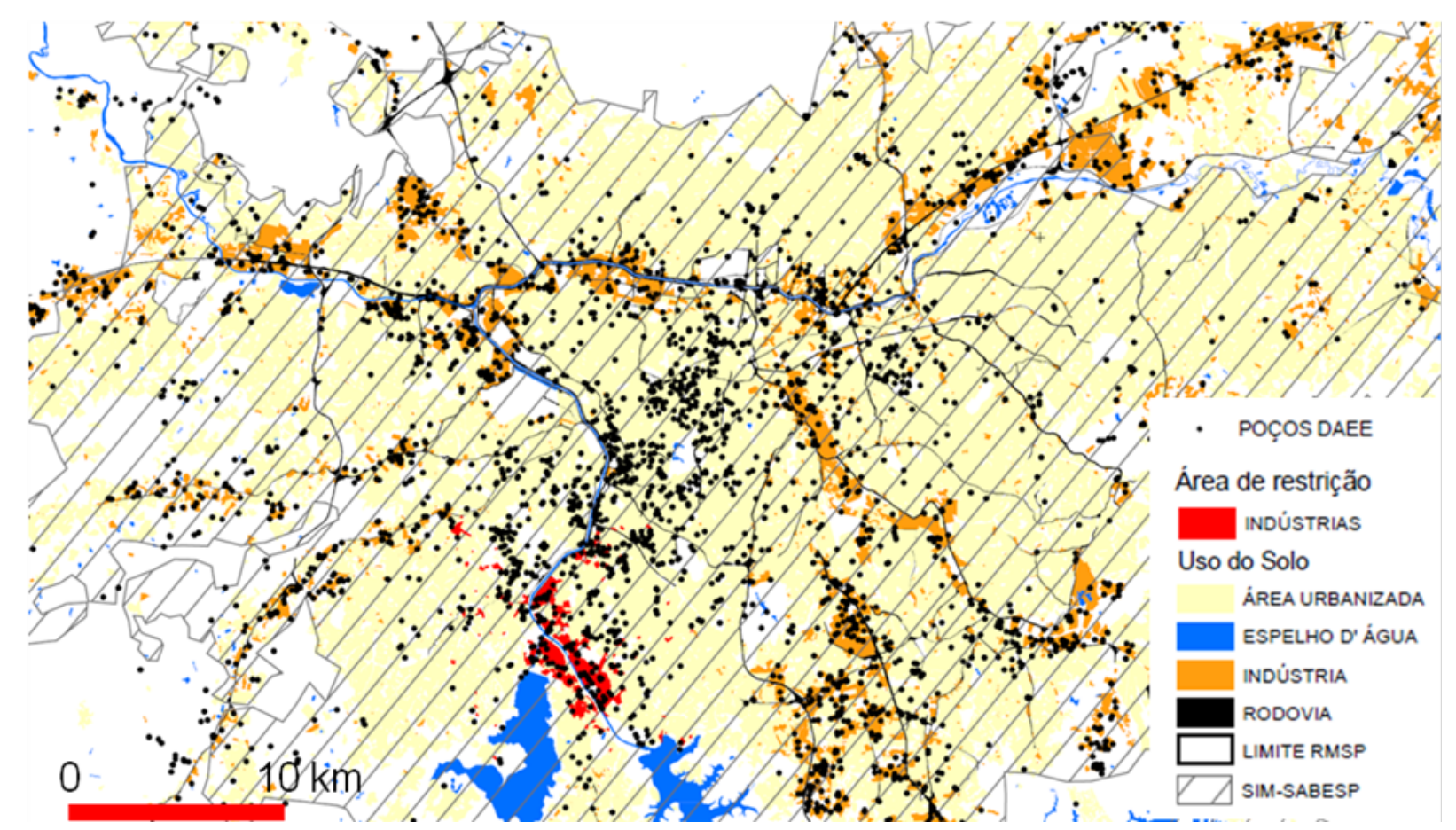

Figura 1 - Localização de áreas industriais e de poços outorgados na Região Metropolitana de São Paulo. Modificado de CEPAS-USP (2016).

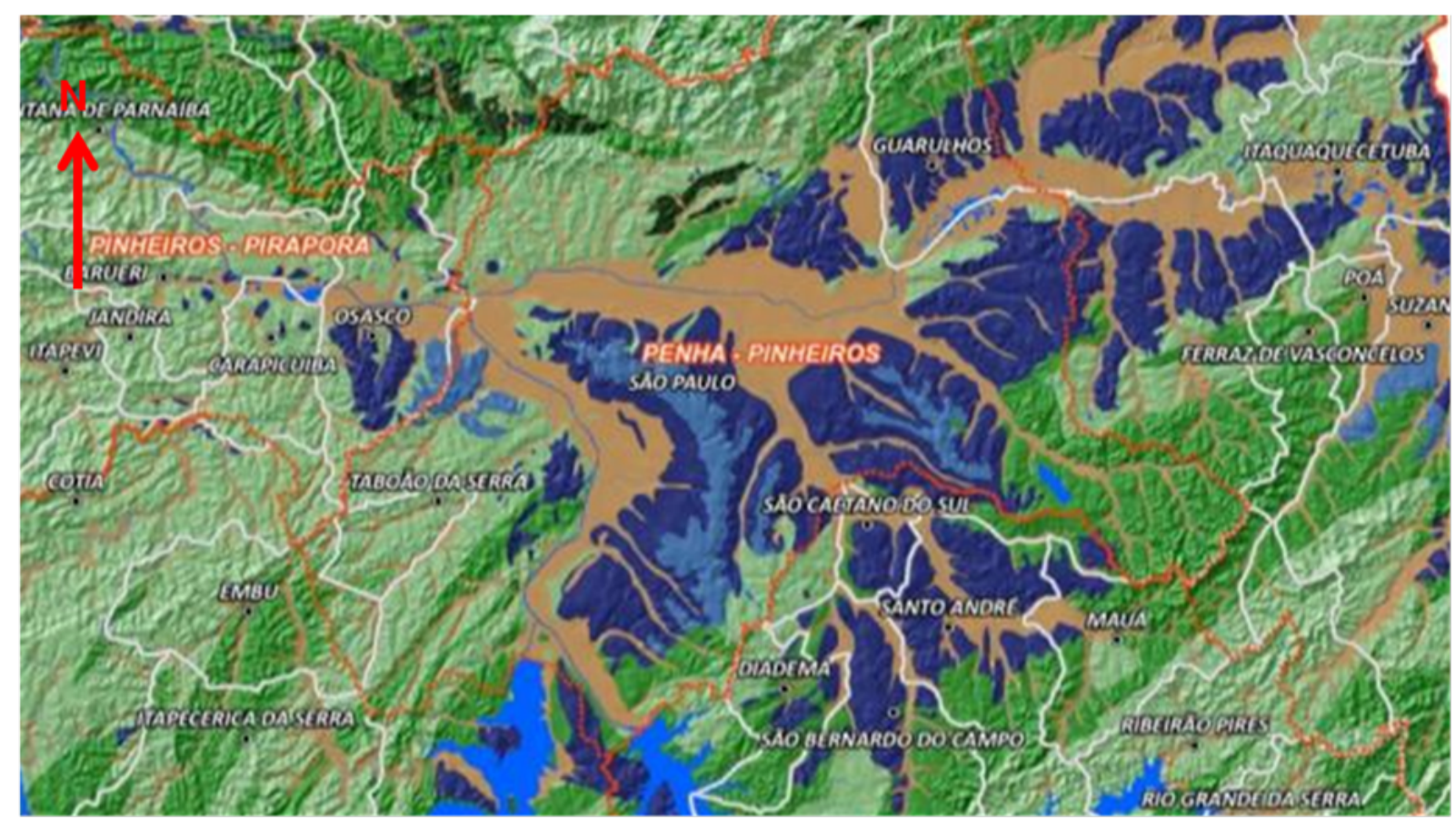

Verde claro: Aquífero fraturado - granitóides, gnaisses, xistos

Verde escuro: Aquífero fraturado - metassedimentos

Azul claro: Aquífero São Paulo

Azul escuro: Aquífero Resende

Marrom: sedimentos quaternários

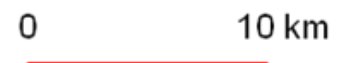

Figura 2 - Mapa de aquíferos de parte da Região Metropolitana de São Paulo. Modificado de FABHAT-SERVMAR (2012). 
A Figura 1 apresenta ainda a localização de poços profundos outorgados na RMSP. Notase que uma grande quantidade de poços situa-se junto às áreas industriais. Via de regra, os poços profundos da RMSP extraem água do aquífero fraturado, na ordem de vários milhares, sendo a porção aquífera sedimentar rasa e de porosidade intergranular normalmente isolada do poço. Não raro, poços profundos situados próximos de áreas contaminadas por solventes organoclorados apresentam-se contaminados por estes compostos, caso por exemplo dos poços da região do Jurubatuba, destacada em vermelho na Figura 1. O surgimento de casos de contaminação de poços de abastecimento representa um considerável transtorno para o Poder Público, dada as condições claras de riscos à saúde a que os consumidores da água subterrânea estão expostos, além do prejuízo econômico que ocorre com a perda dos poços e do próprio recurso hídrico.

A localização dos casos conhecidos de áreas contaminadas por solventes organoclorados na RMSP é apresentada na Figura 3. Sabe-se que em praticamente todos os casos, as investigações realizadas para caracterização da qualidade do solo e água subterrânea se restringem dos primeiros metros de profundidade até, no máximo, o topo da rocha alterada dura e impenetrável à ferramenta de perfuração. São muito raros os casos em que as investigações adentraram a rocha dura. Há várias razões que são declaradas pelos responsáveis técnicos e legais por áreas contaminadas para não investigar os aquíferos fraturados. Dentre os argumentos, enumeram-se:

- “o meio fraturado é muito heterogêneo e anisotrópico, sendo difícil prever onde realizar as perfurações de investigação, suas quantidades e profundidades";

- “os custos das investigações no fraturado são proibitivos, especialmente na condição das incertezas do argumento anterior";

- “a água subterrânea do aquífero fraturado faz parte de sistemas de fluxo mais profundos. Se a água está contaminada, então a contaminação pode ter sido originada pelo 'meu vizinho', então a responsabilidade não é 'só minha'”;

- "o aquífero fraturado tem porosidade muito menor que os aquíferos de porosidade intergranular, resultando que há muito pouca massa de contaminação nele. $\mathrm{O}$ foco da investigação e remediação deve acontecer no aquífero raso, e não num meio de pouca massa e cheio de tantas incertezas." 


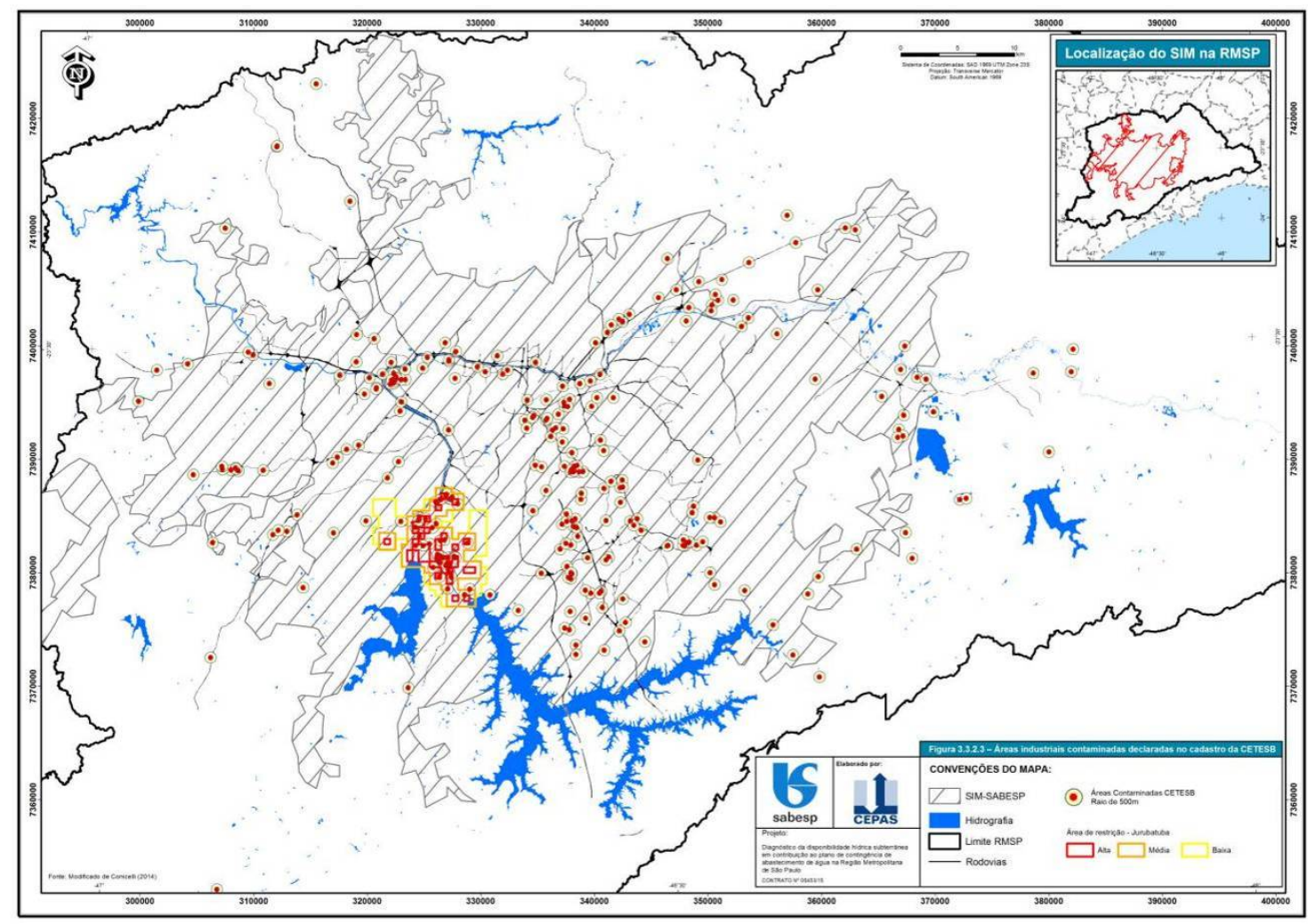

Figura 3 - Localização de áreas contaminadas por solventes organoclorados na RMSP e área de restrição de bombeamento do Jurubatuba (CEPAS-USP, 2016)

Há porém outros contra-argumentos que justificam a necessidade de se empreender esforços para a investigação dos aquíferos fraturados contaminados. A primeira é a de que, embora a matriz de um aquífero granítico-gnáissico fresco e fraturado retenha pouca massa de contaminante, é necessário saber para onde a contaminação está indo, de forma a possibilitar a proteção de possíveis receptores humanos e ecológicos. Além disso, as velocidades da água subterrânea em aquíferos fraturados são bem mais elevadas que nos aquíferos de porosidade primária, sendo comuns aquelas da ordem de vários metros por dia. Se o aquífero fraturado se encontrar sob efeito de bombeamento de poços de abastecimento, o potencial é inclusive de um ainda mais rápido deslocamento de plumas, que podem alcançar dimensões quilométricas em prazos curtos. Estes aspectos precisam ser conhecidos em casos de contaminação de aquíferos fraturados.

Outro aspecto relevante e que justifica a necessidade de investigação de aquíferos fraturados se refere ao desconhecimento existente sobre o real potencial das rochas graníticasgnáissicas, comuns no embasamento cristalino da região centro-sul do Brasil, de também apresentarem porosidade primária originada pelo intemperismo químico. Até que profundidades 
isso pode ocorrer? Sabe-se que as técnicas de perfuração utilizadas em projetos ambientais, como a sondagem rotativa por trado oco, tem as profundidades de investigação limitadas pela dureza da rocha. Quanto de porosidade intergranular existe na rocha alterada dura abaixo da profundidade possível de se atingir com uma sonda de trado oco? Quanto de massa de contaminante próximo da área fonte pode ser estocado nesta rocha alterada dura? Se estas profundidades não são investigadas, então uma possível remediação poderá não ser eficiente.

$\mathrm{O}$ argumento de que é custoso e difícil prever onde, quanto e como realizar as investigações deve ser revisto à luz destes contra-argumentos. Ademais, e se houver suspeitas de ocorrência de fase livre densa não-aquosa (DNAPL) na área fonte? Como não realizar investigações mais robustas para a delimitação do problema ambiental nestas ocasiões? Necessário será, desta forma, encontrar meios de se desenvolver tecnologias de investigação acessíveis, inspiradas no que existe de mais avançado nos dias de hoje, para tornar viável as tarefas de investigação nos aquíferos fraturados. Ainda, nota-se que poucas empresas de consultoria possuem acesso a profissionais treinados e em condições de coordenar projetos de investigação de contaminação em aquíferos fraturados, que sabem quais técnicas podem ser utilizadas, como priorizá-las e como interpretá-las. Esforços necessitam ser realizados para ampliar o número de técnicos aptos a trabalhar neste tema.

\section{2 - Objetivos}

Considerando os problemas lançados no item anterior, esta tese tem como objetivo contribuir com elementos para propor as bases técnicas para a gestão de áreas contaminadas por compostos organoclorados em aquíferos fraturados, considerando as peculiaridades destes aquíferos em ambiente de clima tropical úmido e localizados no contexto da região centro-sul do Brasil, onde frequentemente ocorrem rochas graníticas-gnáissicas com espesso manto de intemperismo, situação esta que se parece conjugar apenas nesta região do mundo.

Faz parte da abordagem deste trabalho, realizar uma avaliação das técnicas e tecnologias disponíveis para investigação de aquíferos fraturados e que foram testadas pelo grupo de pesquisa do CEPAS-USP nos últimos anos, e também indicar/sugerir quais seriam as atividades necessárias e a sequência de atividades a serem realizadas nestes casos. Reflexões sobre a forma de se abordar o gerenciamento de casos ainda mais complexos, como a da existência de fontes multipontuais de contaminação de compostos organoclorados em aquífero cristalino, também são apresentados, tendo o caso da região de Jurubatuba como laboratório. 
Este trabalho não tem a pretensão de esgotar os assuntos tratados, ou mesmo de propor ações pretensamente definitivas para a gestão dos problemas ambientais ocasionados por estas áreas contaminadas. Isto porque este autor reconhece que a gestão deste tipo de problema ambiental é uma arte complexa, multidisciplinar e que demanda a experiência de vários profissionais e de várias instituições. Além disso, no que se refere às pesquisas realizadas pela equipe do CEPAS-USP, há várias atividades de obtenção e interpretação de dados que estão em andamento ainda durante a redação deste texto, e novas contribuições serão oferecidas nas futuras dissertações e teses da equipe.

\section{3 - Estrutura da Tese}

Esta tese se organiza apresentando inicialmente um capítulo de fundamentação teórica, indicando quais são os conceitos de base sobre o comportamento geoquímico dos solventes clorados em subsuperfície e sobre como se dá o fluxo da água subterrânea e o transporte e destino destes contaminantes em aquíferos fraturados. Neste capítulo, também são apresentadas as principais técnicas de investigação de aquíferos fraturados.

O capítulo seguinte apresenta uma descrição das principais investigações que foram realizadas na região do Jurubatuba, onde as técnicas e equipamentos de investigação de aquíferos fraturados foram testados. Muitas das investigações no Jurubatuba ainda encontram-se em andamento e referem-se aos respectivos projetos de pós-graduação da equipe do CEPAS-USP, razão pela qual os resultados apresentados são limitados, mas suficientes para identificar as principais perguntas científicas que foram se revelando com o tempo do projeto e também proporcionar uma avaliação das técnicas e equipamentos que podem ser utilizados em outros projetos similares de gerenciamento de áreas contaminadas em aquíferos fraturados, tema este do capítulo 4 deste trabalho.

Finalmente, o capítulo 5 apresenta reflexões pessoais sobre a gestão de áreas contaminadas em aquíferos fraturados, indicando atividades que são mais ou menos prioritárias de se realizar em situações de investigação de fontes de contaminação únicas e múltiplas.

Os anexos apresentam três artigos científicos que oferecem base para discussões. O primeiro (Fernandes et al, 2016), descreve os resultados da investigação que resultou na definição de um modelo conceitual geológico-estrutural da área do Jurubatuba, discutido especialmente no capítulo 3. O segundo (Fanti et al, 2017) apresenta os resultados de uma investigação de contaminação em aquífero fraturado e uma avaliação é realizada no capítulo 5, 
sobre as técnicas e ferramentas utilizadas. O terceiro artigo (Barbosa et al, 2017) apresenta um método para gerenciamento de informações ambientais aplicado a áreas contaminadas por fontes multipontuais e que dão base para as discussões apresentadas também no capítulo 5 deste trabalho.

\section{Capítulo 2 - Fundamentação Teórica}

\section{1 - Comportamento Geoquímico dos Hidrocarbonetos Alifáticos Clorados}

Os compostos hidrocarbonetos alifáticos clorados considerados neste trabalho correspondem aos etanos, etenos e metanos clorados (Tabela 1). No geral, estes compostos são relativamente leves (massa molar variando de 51 a 168), de solubilidade variável, mas geralmente de baixa a moderada (206 a 13000 mg/L) e são mais densos que a água (com exceção do clorometano, cloroetano e cloreto de vinila). Apresentam-se, também geralmente, com viscosidade menor que a da água e com elevados valores de pressão de vapor, o que lhes conferem, respectivamente, grande mobilidade em espaços intergranulares e a propriedade de serem voláteis (Pankow \& Cherry, 1996). Quando dissolvidos em água, podem também sofrer volatilização para a atmosfera da zona não saturada, em especial os compostos cloreto de vinila, tetracloreto de carbono, tetracloroeteno e 1,1,1 tricloroetano, dado os elevados valores de constante de Lei de Henry.

Os valores de coeficiente de partição entre o carbono orgânico e a água $\left(\mathrm{K}_{\mathrm{oc}}\right)$ indicam a afinidade dos compostos em serem adsorvidos pelo carbono orgânico sólido do material geológico em subsuperfície (Tabela 1). Os compostos alifáticos clorados exibem valores de $\mathrm{K}_{\mathrm{oc}}$ relativamente baixos (com exceção do tetracloroeteno), o que indica que a mobilidade destes compostos em aquíferos é relativamente maior em comparação com outros compostos organoclorados mais pesados.

Já os valores muito baixos de concentrações máximas toleráveis na água (MCL - Tabela 1), baseadas em risco à saúde humana por ingestão, dão a medida da elevada toxicidade destes compostos, muitos dos quais comprovadamente carcinogênicos: bastam poucas partes por bilhão do soluto para inviabilizar a potabilidade de grande volume de água. A ocorrência de fase líquida não-aquosa destas substâncias no aquífero significa, na prática, uma fonte praticamente infinita de contaminação para a água subterrânea, o que representa um grande desafio para o saneamento das áreas contaminadas. 
Os compostos que geralmente possuem aplicação como solventes e desengraxantes em ambiente industrial são o tetracloreto de carbono (TCC), clorofórmio (TCM), tetracloroeteno (PCE), tricloroeteno (TCE) e os isômeros de tricloroetano (TCA). Estes são considerados compostos-pais e são todos mais densos que a água, de baixa viscosidade e de baixa a média solubilidade, situação esta que leva comumente à formação de fase líquida não-aquosa em aquíferos, que se desloca verticalmente para baixo até que uma barreira geológica impermeável seja atingida, mesmo em situações de vazamentos relativamente pequenos (Figura 4).

Tabela 1 - Propriedades físico-químicas de compostos hidrocarbonetos alifáticos clorados.

\begin{tabular}{|c|c|c|c|c|c|c|c|c|c|}
\hline & Fórmula & $\begin{array}{c}\text { Massa } \\
\text { molar } \\
(\mathrm{g} / \mathrm{mol})\end{array}$ & $\begin{array}{c}\text { Solubi } \\
\text {-lidade } \\
(\mathrm{mg} / \mathrm{L})\end{array}$ & $\begin{array}{l}\text { Dens. } \\
\left(\mathrm{g} / \mathrm{cm}^{3}\right)\end{array}$ & $\begin{array}{l}\text { Visco- } \\
\text { sidade } \\
(\mathrm{cp}) \\
\end{array}$ & $\begin{array}{l}\text { Pressão } \\
\text { Vapor } \\
(\mathrm{mm} \mathrm{Hg})\end{array}$ & $\begin{array}{c}\text { Cte. } \\
\text { Henry } \\
(-) \\
\end{array}$ & $\begin{array}{c}\mathrm{K}_{\mathrm{oc}} \\
(\mathrm{L} / \mathrm{kg})\end{array}$ & $\begin{array}{l}\text { MCL* } \\
(\mu \mathrm{g} / \mathrm{L})\end{array}$ \\
\hline TCC & $\mathrm{CCl}_{4}$ & 153,8 & 793 & 1,59 & 0,97 & 115 & 1,13 & 43,9 & 5 \\
\hline $\mathrm{TCM}$ & $\mathrm{CHCl}_{3}$ & 119,4 & 7950 & & 0,56 & 197 & 0,15 & 31,8 & 80 \\
\hline DCM & $\mathrm{CH}_{2} \mathrm{Cl}_{2}$ & 84,9 & 13000 & 1,33 & 0,44 & 435 & 0,13 & 21,7 & 5 \\
\hline $\mathrm{CM}$ & $\mathrm{CH}_{3} \mathrm{Cl}$ & 50,5 & 5320 & 0,91 & - & 4300 & 0,36 & 13,2 & - \\
\hline PCE & $\mathrm{C}_{2} \mathrm{Cl}_{4}$ & 165,8 & 206 & & 0,90 & 18,5 & 0,72 & 364 & 5 \\
\hline TCE & $\mathrm{C}_{2} \mathrm{HCl}_{3}$ & 131,4 & 1280 & 1 & 0,57 & 9 & 0,40 & 60,7 & 5 \\
\hline 1,1DCE & $\mathrm{C}_{2} \mathrm{H}_{2} \mathrm{Cl}_{2}$ & 96,9 & 2420 & 1,21 & 0,36 & 600 & 1,07 & 31,8 & 7 \\
\hline $\mathrm{c} 1,2 \mathrm{DCE}$ & $\mathrm{C}_{2} \mathrm{H}_{2} \mathrm{Cl}_{2}$ & 96,9 & 6410 & & 0,48 & 200 & 0,17 & 39,6 & 70 \\
\hline $\mathrm{t} 1,2 \mathrm{DCE}$ & $\mathrm{C}_{2} \mathrm{H}_{2} \mathrm{Cl}_{2}$ & 96,9 & 4520 & 1,26 & 0,40 & 331 & 0,38 & 39,6 & 100 \\
\hline $\mathrm{CV}$ & $\mathrm{C}_{2} \mathrm{H}_{3} \mathrm{Cl}$ & 62,5 & 8800 & 0,91 & - & 2980 & 1,14 & 21,7 & 2 \\
\hline $1 \mathrm{PCA}$ & $\mathrm{C}_{2} \mathrm{H}_{2} \mathrm{Cl}_{4}$ & 167,9 & 1070 & 1,54 & - & 12,0 & 0,10 & 86,0 & - \\
\hline $2 \mathrm{PCA}$ & $\mathrm{C}_{2} \mathrm{H}_{2} \mathrm{Cl}_{4}$ & 167,9 & 2830 & 1,6 & 1,76 & 4,62 & 0,02 & 94,9 & - \\
\hline 1TCA & $\mathrm{C}_{2} \mathrm{H}_{3} \mathrm{Cl}_{3}$ & 133,4 & 720 & 1,34 & 0,84 & 124 & 0,70 & 43,9 & 200 \\
\hline 2TCA & $\mathrm{C}_{2} \mathrm{H}_{3} \mathrm{Cl}_{3}$ & 133,4 & 4500 & 1,44 & - & 23 & 0,03 & 60,7 & 5 \\
\hline $1,1 \mathrm{DCA}$ & $\mathrm{C}_{2} \mathrm{H}_{4} \mathrm{Cl}_{2}$ & 99,0 & 5040 & 1,18 & 0,50 & 227 & 0,23 & 31,8 & - \\
\hline $1,2 \mathrm{DCA}$ & $\mathrm{C}_{2} \mathrm{H}_{4} \mathrm{Cl}_{2}$ & 99,0 & 8600 & 1,25 & 0,84 & 78,9 & 0,05 & 39,6 & 5 \\
\hline $\mathrm{CA}$ & $\mathrm{C}_{2} \mathrm{H}_{5} \mathrm{Cl}$ & 64,5 & 6710 & 0,89 & - & 1008 & 0,45 & 21,7 & - \\
\hline \multicolumn{10}{|c|}{$\begin{array}{l}T C C=\text { tetracloreto de carbono; } T C M=\text { clorofórmio; } D C M=\text { diclorometano; } C M= \\
\text { clorometano; PCE= tetracloroeteno; TCE = tricloroeteno; } 1,1 D C E, c 1,2 D C E \text { e t1,2DCE }= \\
\text { isômetros do dicloroeteno; } C V=\text { cloreto de vinila; } 1 P C A=1,1,1,2 \text {-tetracloroetano; } 2 P C A= \\
\text { 1,1,2,2-tetracloroetano; } 1 T C A=1,1,1 \text {-tricloroetano; } 2 T C A=1,1,2 \text {-tricloroetano; } 1,1 D C A= \\
\text { 1,1-dicloroetano; } 1,2 D C A=1,2 \text {-dicloroetano; } C A=C l o r o e t a n o . ~ * M C L=\text { concentração } \\
\text { máxima em água com base em metas de risco carcinogênico, de } 10^{-6} \text {, e não-carcinogênico, de } 1 . \\
\text { Fontes: várias, compiladas em USEPA (2016). }\end{array}$} \\
\hline
\end{tabular}

Quando dissolvidos em água, os compostos-pais podem encontrar situações biogeoquímicas propícias em subsuperfície para serem naturalmente degradados para os compostos-filhos, menos clorados. Os processos destrutivos dos compostos organoclorados 
podem ser químicos (abióticos) ou intermediados por microorganismos (bióticos). Exemplo de decaimento abiótico são as transformações de 1,1,1 TCA, 1,1DCA e de CA para acetato, em taxas que variam em função do $\mathrm{pH}$ e da temperatura do meio. Outro exemplo é a redução de um etenoclorado (p.ex. tricloroeteno) por ferro bivalente em solução (Wiedemeier et al, 1999).

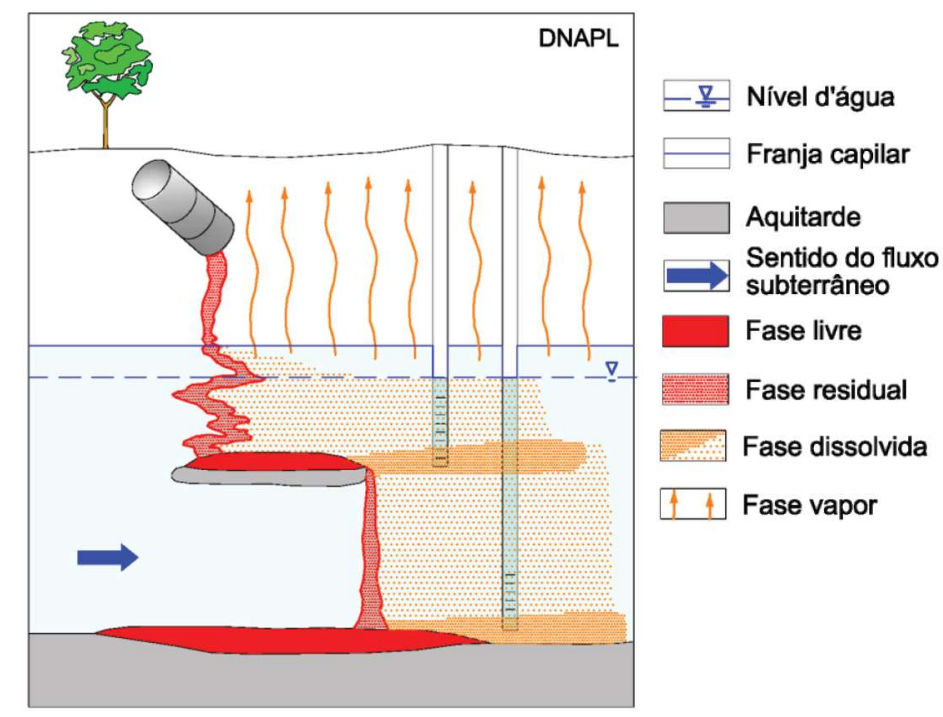

Figura 4 - Modelo conceitual de contaminação de aquífero raso oriunda de um vazamento de DNAPL (Bertolo et al., 2017)

Entretanto, as reações mais comuns de degradação de compostos organoclorados são aquelas de óxi-redução catalisadas por microorganismos (em geral bactérias e fungos). Neste processo, alguns compostos organoclorados podem ser oxidados e funcionam como doadores de elétrons, enquanto outros podem ser reduzidos, funcionando como receptores de elétrons. Os compostos podem ser também degradados via cometabolismo, que é um processo em que o composto é casualmente degradado por uma enzima produzida durante o metabolismo microbiano de um outro composto. A Tabela 2 apresenta os principais tipos de reações de biodegradação que ocorrem com os hidrocarbonetos alifáticos clorados. Dentre todas as classes de reações, a decloração redutiva anaeróbica é a mais importante, por propiciar a degradação da maior parte dos organoclorados leves, e por ser a que mais extensivamente ocorre na natureza (Wiedemeier et al, 1999). Da Tabela 2, chama a atenção o fato de que os principais compostospais (TCC, TCM, PCE, TCE, 1TCA) não degradam naturalmente por oxidação aeróbica ou anaeróbica, reações estas das mais comuns para a biodegradação de hidrocarbonetos de petróleo. 
Tabela 2 - Tipos de reações de biodegradação de compostos organoclorados (Wiedemeier et al, 1999)

\begin{tabular}{|c|c|c|c|c|c|}
\hline Composto & $\begin{array}{c}\text { Decloração } \\
\text { Redutiva }\end{array}$ & $\begin{array}{l}\text { Oxidação } \\
\text { Aeróbica }\end{array}$ & $\begin{array}{c}\text { Oxidação } \\
\text { Anaeróbica }\end{array}$ & $\begin{array}{c}\text { Cometabolismo } \\
\text { aeróbico }\end{array}$ & $\begin{array}{c}\text { Cometabolismo } \\
\text { anaeróbico }\end{array}$ \\
\hline TCC & $\mathrm{X}$ & & & & $X$ \\
\hline TCM & $\mathrm{X}$ & & & $X$ & $X$ \\
\hline DCM & & $X$ & $X$ & $\mathrm{X}$ & \\
\hline PCE & $\bar{X}$ & & & & $X$ \\
\hline TCE & $X$ & & & $X$ & $X$ \\
\hline DCE & $\mathrm{X}$ & $X$ & $\mathrm{X}$ & $X$ & $X$ \\
\hline $\mathrm{CV}$ & $X$ & $X$ & $X$ & $X$ & $X$ \\
\hline $1,1,1 \mathrm{TCA}$ & $\bar{X}$ & & & $\mathrm{X}$ & $\bar{X}$ \\
\hline $1,2 \mathrm{DCA}$ & $\mathrm{X}$ & X & & $X$ & $X$ \\
\hline $\mathrm{CA}$ & & $X$ & & $X$ & \\
\hline
\end{tabular}

$\mathrm{Na}$ decloração redutiva anaeróbica, os contaminantes organoclorados sofrem redução química, ou seja, são receptores de elétrons e oxidam outra substância. Esta classe de reações é intermediada especialmente por bactérias do gênero Dehalococcoides, dentre outras, que obtém energia e cria biomassa a partir das reações (Wiedemeier et al, 1999). Neste processo, um átomo de cloro do composto organoclorado é substituído por um átomo de hidrogênio. No exemplo da degradação do PCE em TCE, a seguinte reação bioquímica ocorre:

$$
\mathrm{C}_{2} \mathrm{Cl}_{4}+\mathrm{H}_{2} \rightarrow \mathrm{C}_{2} \mathrm{HCl}_{3}+\mathrm{Cl}^{-}+\mathrm{H}^{+}+\text {energia }
$$

Os pré-requisitos para a ocorrência destas reações químicas são que o ambiente deve ser fortemente anaeróbico (baixo potencial redox), com ausência de oxigênio livre e íons nitrato dissolvidos e com adequado suprimento de matéria orgânica em fermentação para a produção do gás hidrogênio. Desta forma, a degradação dos compostos etenos, etanos e metanos clorados por decloração redutiva anaeróbica segue uma sequência tal como indicada na Figura 5.

As velocidades das reações de decloração redutiva anaeróbica são diferentes de composto para composto. Os compostos alifáticos mais clorados e mais oxidados, como o PCE, TCE, TCA e TCC sofrem mais rapidamente a decloração redutiva em ambientes anaeróbicos. Já os compostos menos clorados (mais reduzidos, como os isômeros do DCE, CV, isômeros do DCA, CA, DCM e CM) apresentam maiores dificuldades em se degradarem via decloração redutiva anaeróbica em condições naturais e tendem a se acumular no aquífero (Wiedemeier et al, 1999). 


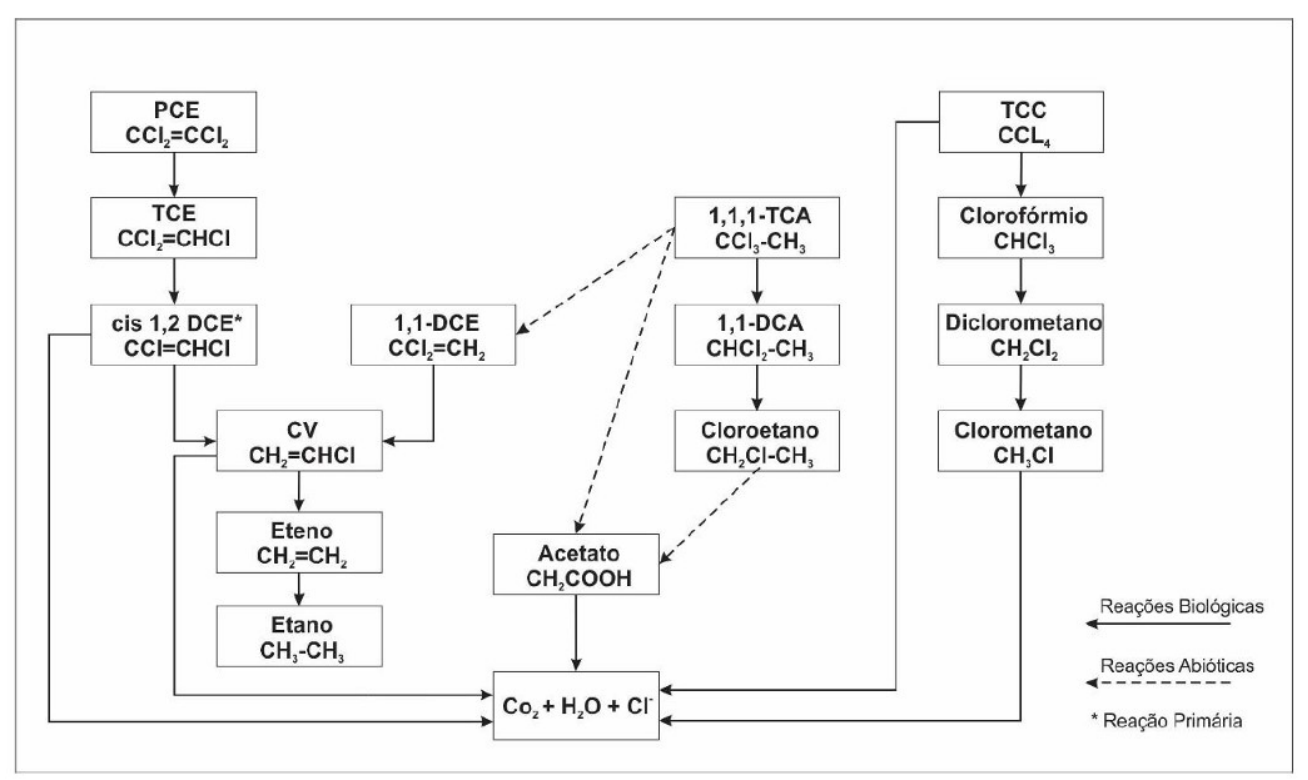

Figura 5 - Sequência de degradação dos compostos hidrocarbonetos alifáticos clorados por decloração redutiva anaeróbica e por processos abióticos (Wiedemeier et al, 1999).

\section{2 - Fluxo de Água e Transporte de Contaminantes em Aquíferos Fraturados}

\subsubsection{Lei de Darcy para Aquíferos Fraturados}

Em rochas cristalinas, os caminhos para o fluxo da água subterrânea se dão fundamentalmente através das fraturas interconectadas, sendo o maciço rochoso em geral considerado impermeável e de porosidade desprezível. Nos aquíferos fraturados, os parâmetros abertura, densidade e conectividade de fraturas são os responsáveis pela ocorrência de fluxo (Domenico \& Schwartz, 1997) e são as principais variáveis que se buscam conhecer para a caracterização hidrogeológica. Na escala de campo, duas abordagens podem ser utilizadas quando se investiga o fluxo da água subterrânea em rochas fraturadas: a do meio contínuo ou do meio descontínuo (ou discreto).

A abordagem do meio contínuo assume que a massa de rocha fraturada é hidraulicamente equivalente a um meio contínuo de porosidade intergranular, situação em que o conceito de Volume Elementar Representativo pode ser aplicado (Domenico e Schwartz, 1997). Desta forma, a aplicação da Lei de Darcy é facilitada para a determinação dos sentidos de fluxo, das vazões e velocidades da água, sendo as técnicas utilizadas em campo para determinação das propriedades de fluxo e estocagem do aquífero frequentemente aquelas tradicionais. 
Porém, se as condições de meio contínuo não existem no aquífero fraturado, o fluxo necessita ser caracterizado através de fraturas individuais ou conjuntos de fraturas, numa abordagem denominada de Rede de Fraturas Discretas (Discrete Fracture Network Approach, DFN, em inglês) (Domenico e Schwartz, 1997). As situações de descontinuidade, em que as propriedades físicas do aquífero variam enormemente no espaço, são as mais comuns em meios fraturados, em especial quando a escala de investigação é regional. Disto decorre a necessidade de se utilizar de técnicas de investigação mais sofisticadas, como as indicadas no capítulo 2.3, para a obtenção de propriedades hidráulicas de fraturas específicas.

A Lei de Darcy é também aplicável para fraturas quando o fluxo encontra-se em regime laminar (não turbulento). A equação que rege o fluxo em fraturas é similar à da Lei de Darcy (Q=A.K.i) e é denominada Lei Cúbica (Snow, 1968 apud Freeze e Cherry, 1979), que indica que a vazão que atravessa determinada fratura, para um dado gradiente hidráulico, é proporcional ao cubo de sua abertura. Para uma fratura de comprimento $w$ e abertura $e$ (Figura 6), a Lei cúbica se escreve:

$$
\begin{aligned}
& Q=-e w \cdot \frac{e^{2} \rho g}{12 \mu} . i \\
& Q=-w \cdot \frac{e^{3} \rho g}{12 \mu} . i
\end{aligned}
$$

\section{Equação 1}

Onde:

$Q=$ vazão $\left(\mathrm{L}^{3} \cdot \mathrm{T}^{-1}\right)$

$e w=$ área perpendicular à fratura, disponível ao fluxo (Figura 6) $\left(\mathrm{L}^{2}\right)$

$i=$ gradiente hidráulico $\left({\mathrm{L} . \mathrm{L}^{-1}}^{-1}\right)$

$\rho=$ densidade da água (M.L ${ }^{-3}$ )

$\mathrm{g}=$ aceleração da gravidade $\left(\mathrm{L}^{\mathrm{T}} \mathrm{T}^{-2}\right)$

$\mu=$ viscosidade dinâmica $\left(M \cdot T^{-1} \cdot L^{-1}\right)$

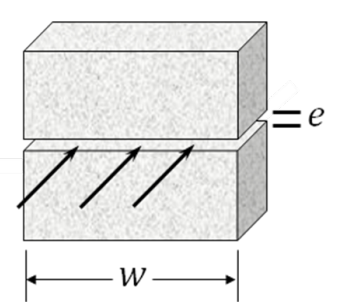

Figura 6 - Fratura de comprimento W e abertura hidráulica $e$. 
Pela equação, o resultado prático indica que para cada ordem de magnitude de aumento do valor da abertura hidráulica de uma fratura, a sua vazão se eleva ao cubo, para um mesmo gradiente hidráulico, conforme se observa na Figura 7.

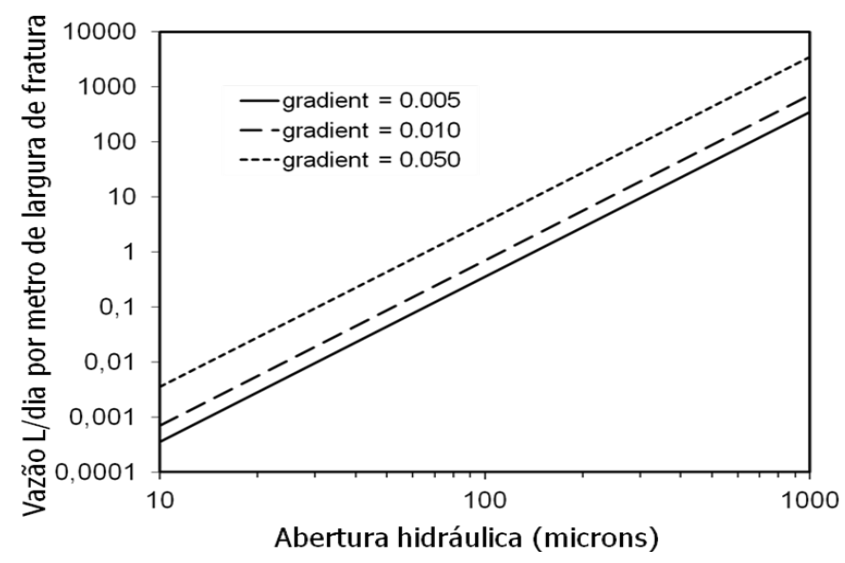

\section{Figura 7 - Relação entre abertura hidráulica de uma fratura simples e sua vazão, para determinado valor de gradiente hidráulico (Kuepper, 2003)}

O termo central da equação da Lei Cúbica refere-se à condutividade hidráulica da fratura simples (Equação 2). Na prática, a condutividade hidráulica da fratura e a abertura hidráulica são obtidos a partir de valores de transmissividade (T) medidos em ensaios em campo, sabendo-se o número de fraturas condutivas num determinado trecho ensaiado no poço (Equação 3).

$$
\begin{array}{cc}
K_{f}=\frac{e^{2} \rho g}{12 \mu} & \text { Equação 2 } \\
e=\left(\frac{T 12 \mu}{n \rho g}\right)^{1 / 3} & \text { Equação 3 }
\end{array}
$$

Onde:

$n$ = número de fraturas num intervalo testado no poço;

$e=$ abertura hidráulica;

$T=$ transmissividade $\left(\mathrm{L}^{2} \cdot \mathrm{T}^{-1}\right)$ (medida a partir de ensaios hidráulicos de campo).

Para uma fratura simples, a obtenção da velocidade real da água subterrânea (fluxo advectivo) também se dá aplicando a Lei de Darcy, considerando o regime de fluxo laminar (Equação 4). Em fraturas, o valor da velocidade se iguala ao fluxo, pois a porosidade efetiva equivale a $100 \%$. Interessante notar que para um gradiente hidráulico de $1 \%$, uma fratura de apenas $0,1 \mathrm{~mm}$ de abertura (100 microns) pode conduzir a água a uma velocidade de cerca de 10 $\mathrm{m} /$ dia (Figura 8). 


$$
v=\frac{e^{2} \rho g}{12 \mu} i \quad \text { Equação } 4
$$

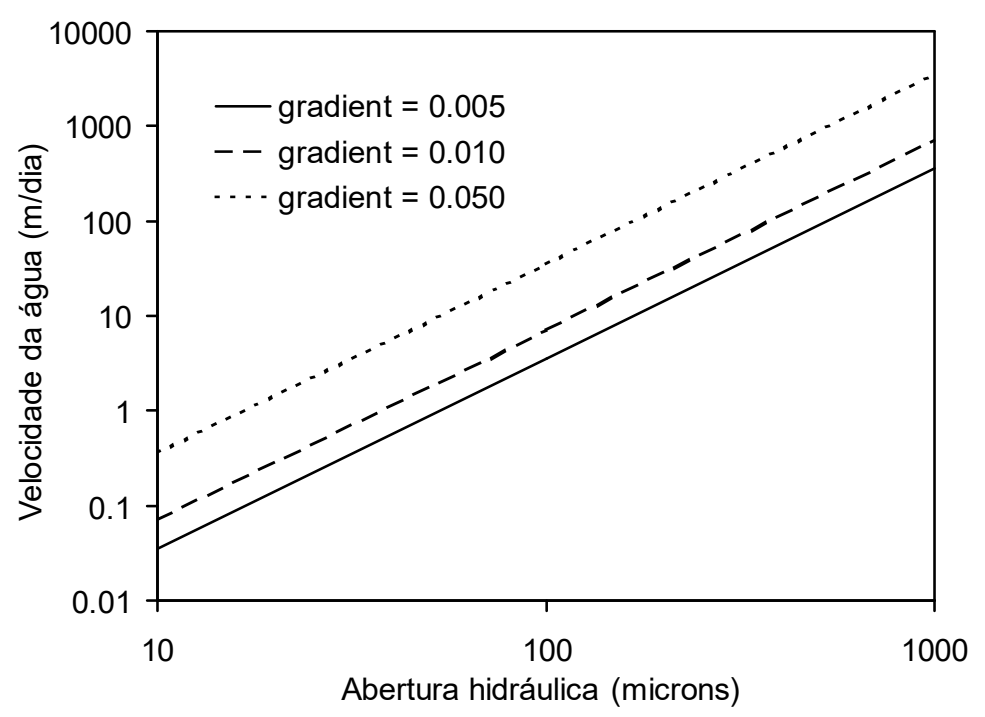

Figura 8 - Relação entre abertura hidráulica de uma fratura simples e a velocidade real da água subterrânea, para determinado valor de gradiente hidráulico (Kuepper, 2003)

\subsubsection{Transporte de Contaminantes em Aquíferos Fraturados}

A Figura 9 exemplifica um modelo conceitual de contaminação de um composto organoclorado mais denso que a água num aquífero fraturado, em que, a partir das fontes de contaminação, o composto derramado infiltra-se por entre as fraturas da formação geológica e passa a se dissolver, formando a pluma de fase dissolvida. Tal como em aquíferos de porosidade intergranular, os processos de advecção, dispersão, retardação e atenuação ocorrem em plumas de contaminação dissolvidas em aquíferos fraturados. Na advecção, a Lei da Darcy é aplicada para os cálculos de vazões e velocidades de fluxo (equações 1 a 4).

A dispersão é um fenômeno dos mais importantes no transporte de contaminantes em aquíferos fraturados, correspondendo à somatória dos fenômenos de dispersão mecânica e molecular. A dispersão mecânica é gerada especialmente pelas variações de rugosidade e abertura das fraturas. Os valores mais elevados de dispersividade ocorrem nas formações mais fraturadas, resultando em menores concentrações de contaminantes, atenuação natural mais rápida e migração mais rápida da borda dianteira da pluma. 


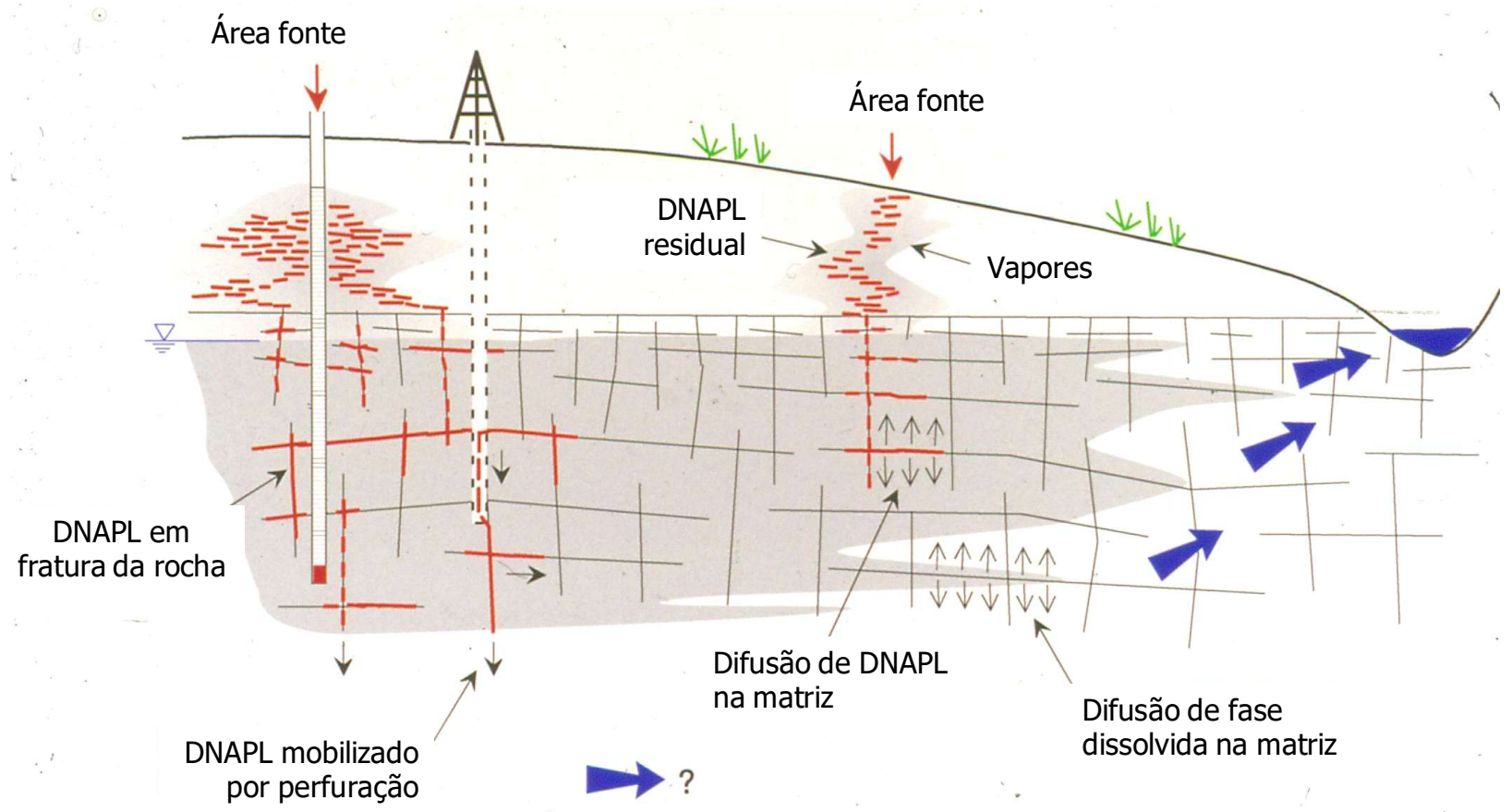

Figura 9 - Modelo conceitual de contaminação de composto organoclorado em aquífero fraturado com porosidade primária (modificado de Reynolds \& Kuepper, 2002).

Uma particularidade importante nos aquíferos fraturados, entretanto, refere-se à possível ocorrência de difusão dos contaminantes através da matriz rochosa a partir das paredes das fraturas (Reynolds \& Kuepper, 2002). Nesta situação, a fase livre do contaminante entra na fratura da rocha que possui alguma porosidade intergranular (Figura 10, $\mathrm{t}=0$ ). O contaminante se dissolve na água e migra por difusão nos poros da matriz. Supondo que num tempo posterior a fratura volte a ter água sem contaminantes $(\mathrm{t}=2)$, o contaminante dissolvido nos poros da matriz passam a sofrer difusão reversa. Este fenômeno ocorre exclusivamente por gradiente de concentração e é um dos principais causadores de dificuldades na aplicação de técnicas de remediação, pois a difusão reversa devolve a contaminação para a água da fratura num processo lento e contínuo. Rochas cristalinas frescas (granitos e gnaisses) geralmente não apresentam porosidade intergranular relevante e não se espera a ocorrência do fenômeno de forma intensa. Entretanto, a rocha cristalina intemperizada, de espessura muito desenvolvida no sudeste do Brasil, representa um importante meio de dupla porosidade onde se espera a ocorrência do fenômeno. 

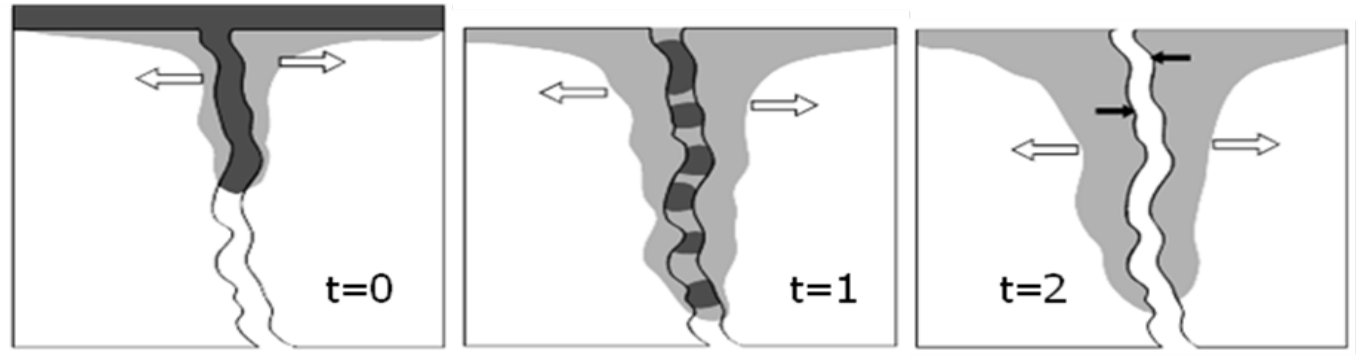

Figura 10 - Ocorrência do fenômeno de difusão do contaminante na matriz a partir da parede do poço e a posterior ocorrência de difusão reversa (Reynolds \& Kuepper, 2002)

A retardação é um outro fenômeno que atua no transporte de contaminantes orgânicos em meios fraturados, sendo mais importante em formações geológicas fraturadas que apresentam matriz com matéria orgânica sólida, como vários tipos de rochas sedimentares. A retardação de contaminantes é função, portanto, do conteúdo de matéria orgânica da rocha e da abertura das fraturas. Quanto maior o conteúdo de matéria orgânica e menor a abertura das fraturas, maior a retardação da pluma de fase dissolvida do contaminante orgânico.

A atenuação natural ou decaimento envolve a diminuição das concentrações dos contaminantes por processos físicos, químicos e bioquímicos, sendo a biodegradação o processo mais importante de destruição de contaminantes orgânicos no aquífero. A biodegradação é um processo em que reações redox de compostos orgânicos são catalisadas por microorganismos, ocorrendo em meios fraturados tal como em meios de porosidade primária. Sua intensidade é função da existência de microorganismos adequados e condições adequadas de $\mathrm{pH}$, potencial redox, tipo e quantidade do contaminante, existência de receptores de elétrons, temperatura, nutrientes e ausência de toxinas (Wiedemeier et al, 1999).

A entrada de fase líquida densa não aquosa (DNAPL) em fraturas é um outro aspecto importante da migração de contaminantes em aquíferos fraturados, especialmente pelo potencial de espalhamento destas substâncias em grandes profundidades. Além do ângulo da fratura e de sua abertura, que vão influenciar na medida da pressão capilar da fratura, a pressão exercida pela altura da coluna de DNAPL é a outra variável que irá definir se o DNAPL irá entrar ou não na fratura (Figura 10, $\mathrm{t}=0$ ). $\mathrm{O}$ esgotamento da fonte de DNAPL faz com que num segundo momento $(\mathrm{t}=1)$ o corpo contínuo de DNAPL se separe, formando a fase residual de DNAPL na fratura (Kuepper, 2003).

O modelo da Figura 11 apresenta o acúmulo vertical de DNAPL numa rede de fraturas, em que se assume que o DNAPL parou de se aprofundar no ponto A por conta do estreitamento da 
abertura da fratura no local, exercendo uma resistência capilar que segura a coluna de DNAPL acima. O gráfico da Figura 11 mostra que a pressão das colunas de água e do DNAPL aumentam linearmente com a profundidade. A relação entre a altura da coluna de DNAPL e a abertura da fratura no ponto A necessária para suportar o acúmulo de DNAPL é dada pela Equação 5 (Kuepper \& McWhorter, 1991). Com base nesta equação, a Figura 12 relaciona a altura mínima de diferentes DNAPLs e a abertura da fratura. Nota-se que uma coluna de pouco mais de $10 \mathrm{~cm}$ de altura de DNAPL é suficiente para entrar em uma fratura de abertura de 100 microns $(0,1$ $\mathrm{mm})$.

$$
H_{D}=\frac{2 \sigma \cos \theta}{\left(\rho_{N}-\rho_{W}\right) g e} \quad \text { Equação } 5
$$

Onde,

$\mathrm{H}_{\mathrm{D}}=$ altura vertical do DNAPL acumulado (L)

$\sigma=$ tensão interfacial do DNAPL-água (N.L²)

$\rho_{\mathrm{N}}=$ densidade do DNAPL $\left({\left.\mathrm{M} . \mathrm{L}^{-3}\right)}^{-3}\right.$

$\rho_{\mathrm{W}}=$ densidade da água $\left(\mathrm{M} \cdot \mathrm{L}^{-3}\right)$

$\theta=$ ângulo de contato dos fluidos (admensional)

$\mathrm{g}=$ aceleração da gravidade $\left(\mathrm{L} . \mathrm{T}^{-2}\right)$

e $=$ abertura hidráulica da fratura $(\mathrm{L})$

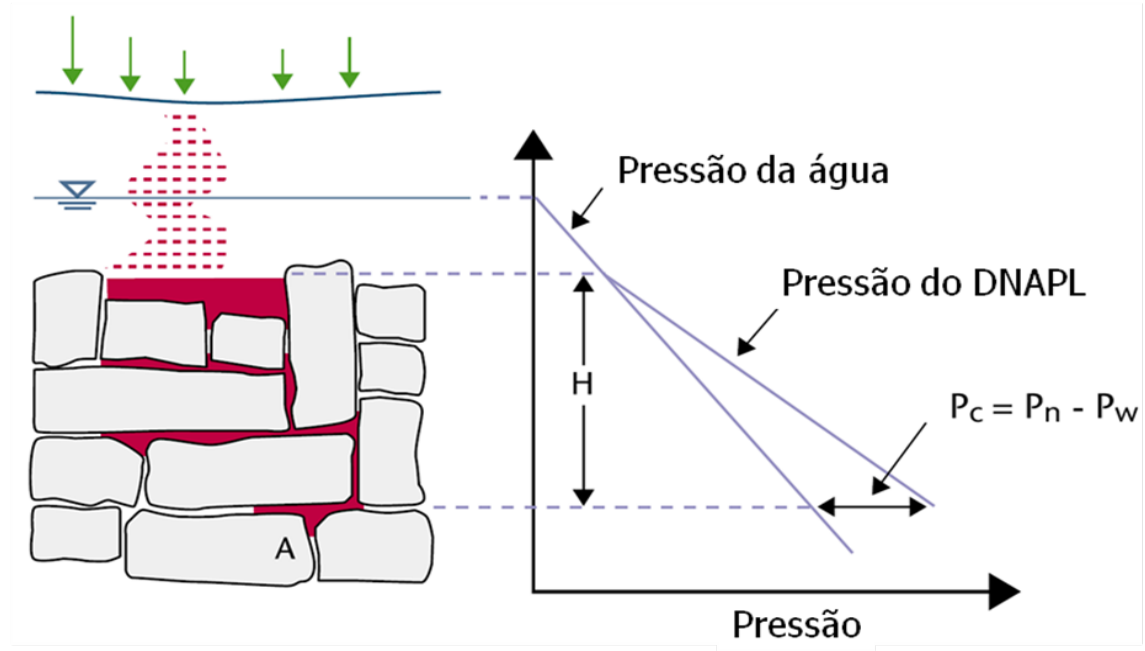

Figura 11 - Acúmulo vertical de DNAPL numa rede de fraturas (Reynolds \& Kuepper, 2002) 


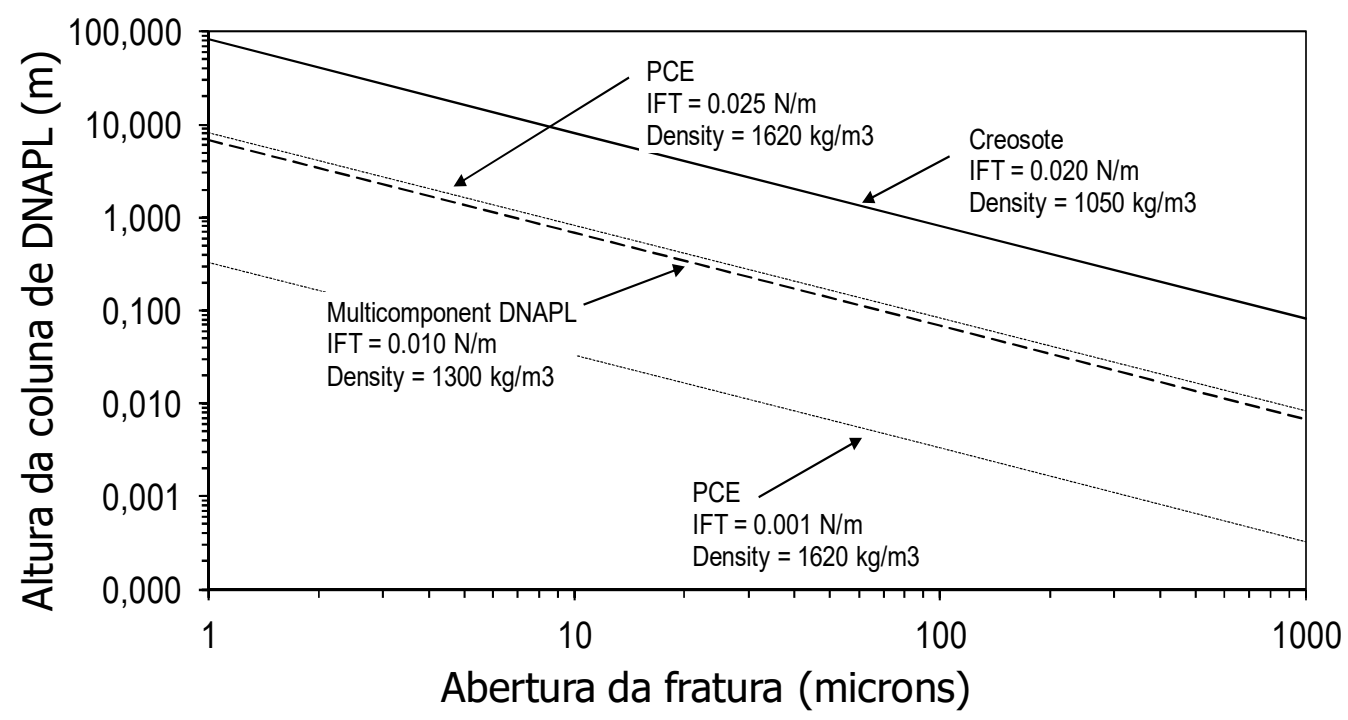

Figura 12 - Relação entre altura mínima de DNAPL e abertura de fratura (Kuepper, 2003)

\section{3 - Técnicas de Investigação de Aquíferos Fraturados - Escalas Regional a}

\section{Local}

O processo de gestão de áreas contaminadas envolve identificar a existência de uma fonte de contaminação, de receptores humanos ou ecológicos à contaminação e um caminho que proporciona o transporte do contaminante, ligando-o aos receptores. Em qualquer projeto de investigação de contaminação de aquíferos, portanto, as seguintes questões precisam ser respondidas: para onde a água subterrânea está se movendo, quais são suas velocidades e vazões e como os contaminantes estão sendo transportados.

No caso de aquíferos fraturados, a resposta a estas questões implica na necessidade de se conhecer: (i) a geologia e a geometria da rede de fraturas (direções, espaçamentos, comprimento, abertura e conectividade), (ii) a interação dos contaminantes com as fraturas e a matriz rochosa e (iii) a possível ocorrência de fluxo multifásico. Uma investigação bem sucedida de aquíferos fraturados é composta de uma série de técnicas aplicadas em escalas regional, local e de detalhe. Requer normalmente a realização de atividades como:

- Definição de famílias de fraturas importantes que controlam a migração de água e de contaminantes;

- Definição da geometria e propriedades hidráulicas destas famílias;

- Medição de cargas hidráulicas de fraturas e definição de conectividade entre fraturas (através de ensaios hidráulicos); 
- Definir o papel da matriz na difusão de contaminantes; e

- Considerar a densidade do DNAPL e os efeitos capilares no movimento da fase livre.

\subsubsection{Levantamento Geológico-Estrutural}

O caminho metodológico para a caracterização da contaminação em aquíferos fraturados inicia-se com a obtenção de informações de geologia e hidrogeologia em escala regional. Mapas geológicos e imagens aéreas e de satélite são obtidos para a realização de análise de lineamentos, que objetiva a obtenção de uma avaliação preliminar das principais tendências estruturais da área de estudo. Lineamento é uma feição linear e mapeável, visível nas imagens aéreas e que possivelmente reflete um fenômeno de subsuperfície, como fraturamento (O’Leary et al. 1976). A avaliação é facilitada com a utilização de imagens de modelo digital de terreno, como exemplificado na Figura 13. O posicionamento de lineamentos próximos à área foco de investigação é de especial interesse, pois isto irá contribuir para orientar as atividades de investigação em escala local.

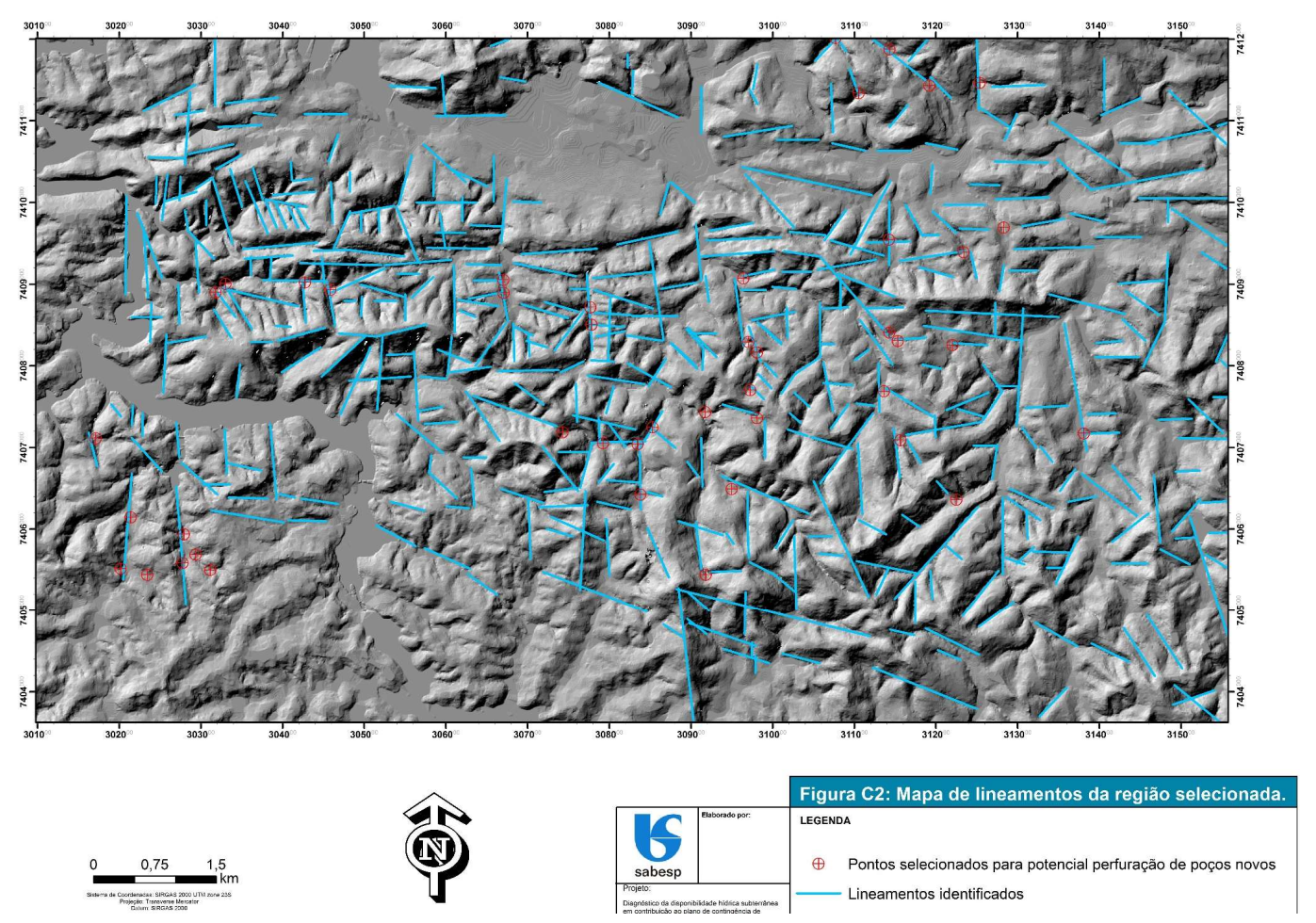

Figura 13 - Exemplo de mapa de lineamentos obtido sobre um modelo digital de terreno (CEPAS-USP, 2016) 
Um levantamento de informações geológico-construtivas de poços profundos localizados no entorno da área foco de interesse também deve ser realizado nas investigações regionais. O cadastro de poços, juntamente com a definição dos principais elementos de drenagem superficial, possibilitam estabelecer as condições de contorno da área a ser hidrogeologicamente investigada. Além disso, os poços cadastrados também podem ser utilizados para as atividades posteriores de perfilagens geofisicas.

O levantamento de estruturas em afloramentos é uma atividade a ser realizada em seguida em escala local, com a finalidade de se identificar os principais grupos de fraturas e os campos de esforços responsáveis pela sua geração, resultando na identificação de quais grupos são probabilisticamente mais favoráveis ao fluxo de água subterrânea. O levantamento de dados estruturais pode ser realizado ao longo de scanlines e observações pontuais em afloramentos próximos à área de interesse (Figura 14). O método consiste na amostragem de fraturas ao longo de uma linha definida em função das dimensões do afloramento observado e das fraturas presentes (Priest, 1993; Fernandes, 2008).
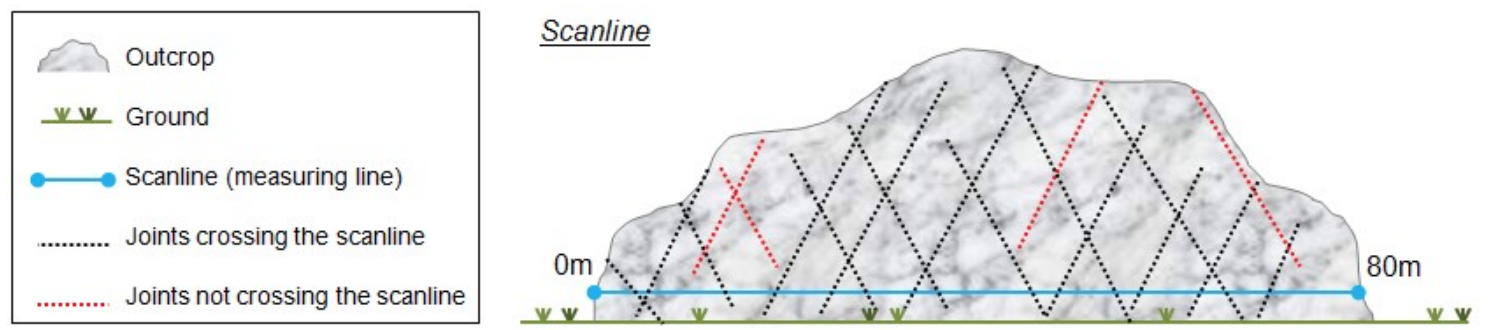

Figura 14 - Esquema da amostragem através do método de scanline (Pino, 2012).

Na aplicação do método, vários parâmetros são coletados: posição da fratura na scanline, se é fratura simples ou uma zona de fraturas, sua espessura e número de fraturas, atitude, direção e caimento de estrias de cisalhamento, cor e espessura de alteração, preenchimento, configuração (se plana ou ondulada), rugosidade, comprimento, terminação em outra fratura. Outras feições importantes de interesse são a presença de água e/ou vegetação ao longo da fratura, estrutura préexistente associada (veio, foliação) e padrões (echelon, flor, conjugado, anastomosado). A coleta de dados estruturais também engloba observações de feições que indicam a orientação de campos de esforços e a idade relativa dos grupos de fraturas (terminações de fraturas), de modo a identificar esforços tectônicos e sua superposição ao longo do tempo. Feições diagnósticas de fluxo (alteração, saídas de água, presença de vegetação) também são registradas, de modo a poder determinar quais grupos de fraturas devem ser as mais transmissivas. 


\subsubsection{Levantamentos Geofísicos de Superfície}

Levantamentos geofísicos de superfície podem ser realizados na escala da área de investigação e próximos de áreas fontes de contaminação para complementar as informações do meio físico necessárias para definir a locação de sondagens de investigação. Trata-se, portanto, de ferramentas utilizadas para se identificar a estratigrafia e estruturas numa escala de maior detalhe em relação aos métodos de levantamento geológico-estrutural.

Talvez o método geofísico mais tradicional utilizado para fins de investigação em rochas fraturadas seja o da eletrorresistividade, nela considerando a sondagem elétrica e o caminhamento elétrico. O caminhamento elétrico se utiliza quando o interesse é o estudo da variação lateral da resistividade das rochas, e mantendo-se uma profundidade constante (Elis \& Zuquette, 1998). Os métodos eletrorresistivos são utilizados na determinação da espessura do manto de intemperismo, da profundidade do topo rochoso, da profundidade da zona saturada, na detecção de caminhos preferenciais ao fluxo subterrâneo, no mapeamento de fraturas, e mesmo na detecção de plumas de contaminação. A eletrorresistividade é uma técnica na qual, por meio de um par de eletrodos cravados na superfície do terreno, se injeta corrente elétrica no subsolo, e por um segundo par de eletrodos posicionados em relação aos de corrente, mede-se a tensão resultante. Pelo valor de tensão, corrente e distância entre eletrodos, calcula-se a resistividade elétrica aparente dos materiais em subsuperfície. Um exemplo de resultado de aplicação do método resistivo é apresentado na Figura 15, em que as rochas do embasamento resistivo de gnaisses do Complexo Embu em Suzano (SP) estão representadas em cores avermelhadas, e as estruturas verticais condutoras de água em tons de azul.

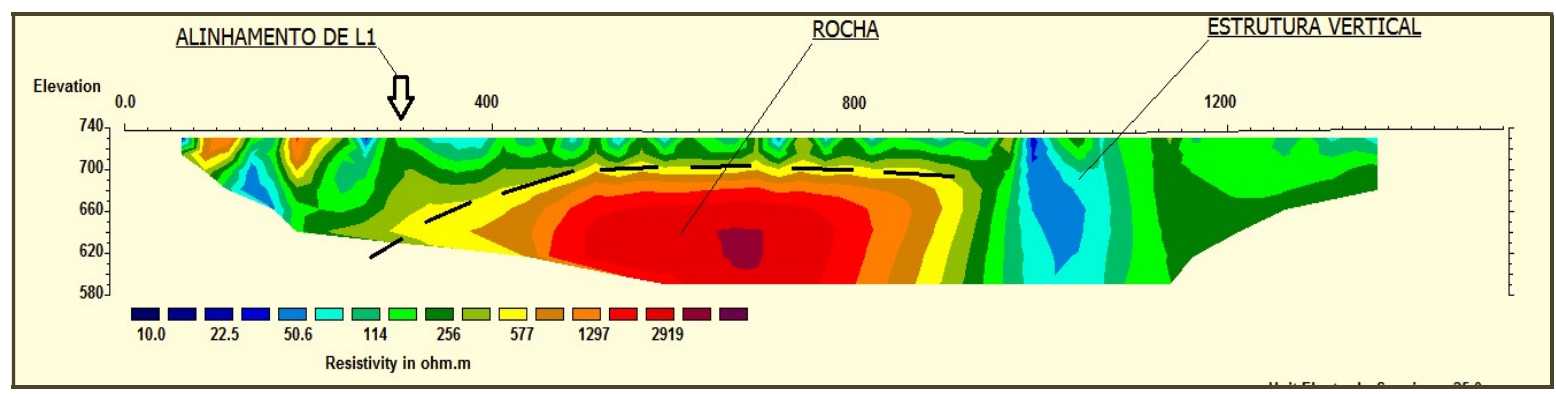

Figura 15 - Exemplo de resultado de caminhamento elétrico executado com arranjo dipolodipolo e Werner (CEPAS-USP, 2016).

Outro método útil é o da sísmica de reflexão, com aplicação para se diferenciar materiais em subsuperfície, individualizar a espessura de camadas de cobertura e obter informações sobre fraturamento e alteração do maciço rochoso. Neste método, uma fonte sísmica de energia 
controlada é utilizada (explosivo, vibração), sendo medido o tempo que uma onda refletida leva até atingir um geofone, de forma a estimar a profundidade da estrutura que gerou a reflexão. Um exemplo de resultado de aplicação do método de sísmica de reflexão é apresentado na Figura 16, em que o topo do maciço rochoso e o posicionamento de falha e fraturas foram mapeados em Guarulhos (SP) para fins de planejamento do traçado de túneis do metrô (Monteiro, 2016).

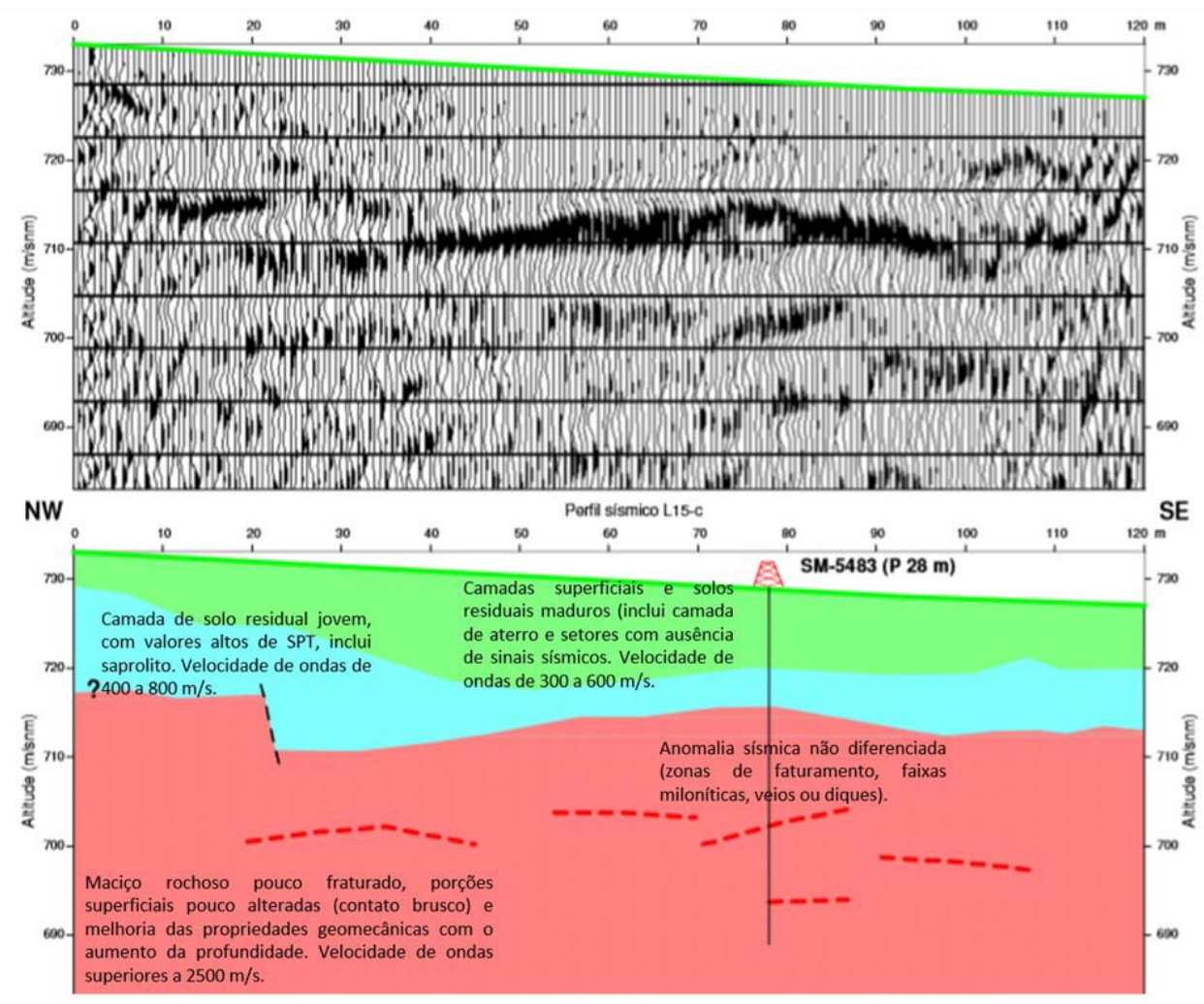

Figura 16 - Exemplo de respostas sísmicas e suas interpretações geológicas (Monteiro, 2016)

\section{4 - Método Discrete Fracture Network (DFN)}

O método Discrete Fracture Network (DFN) (Parker, 2007; Parker et al., 2012) consiste na execução de uma série de atividades que visam a determinar as características físicas e hidráulicas do aquífero fraturado, assim como o comportamento do contaminante tanto na rocha como na água numa escala de detalhe a superdetalhe (Figura 17). Trata-se de um detalhamento das investigações geológicas e hidrogeológicas descritas no item anterior. No método, obtém-se dados de campo para o aprimoramento do modelo conceitual da área contaminada e para utilização em modelagem numérica de transporte de contaminantes, cujos resultados auxiliam no entendimento da dinâmica de plumas e áreas fontes e nas avaliações de cenários de exposição e de alternativas de remediação. 


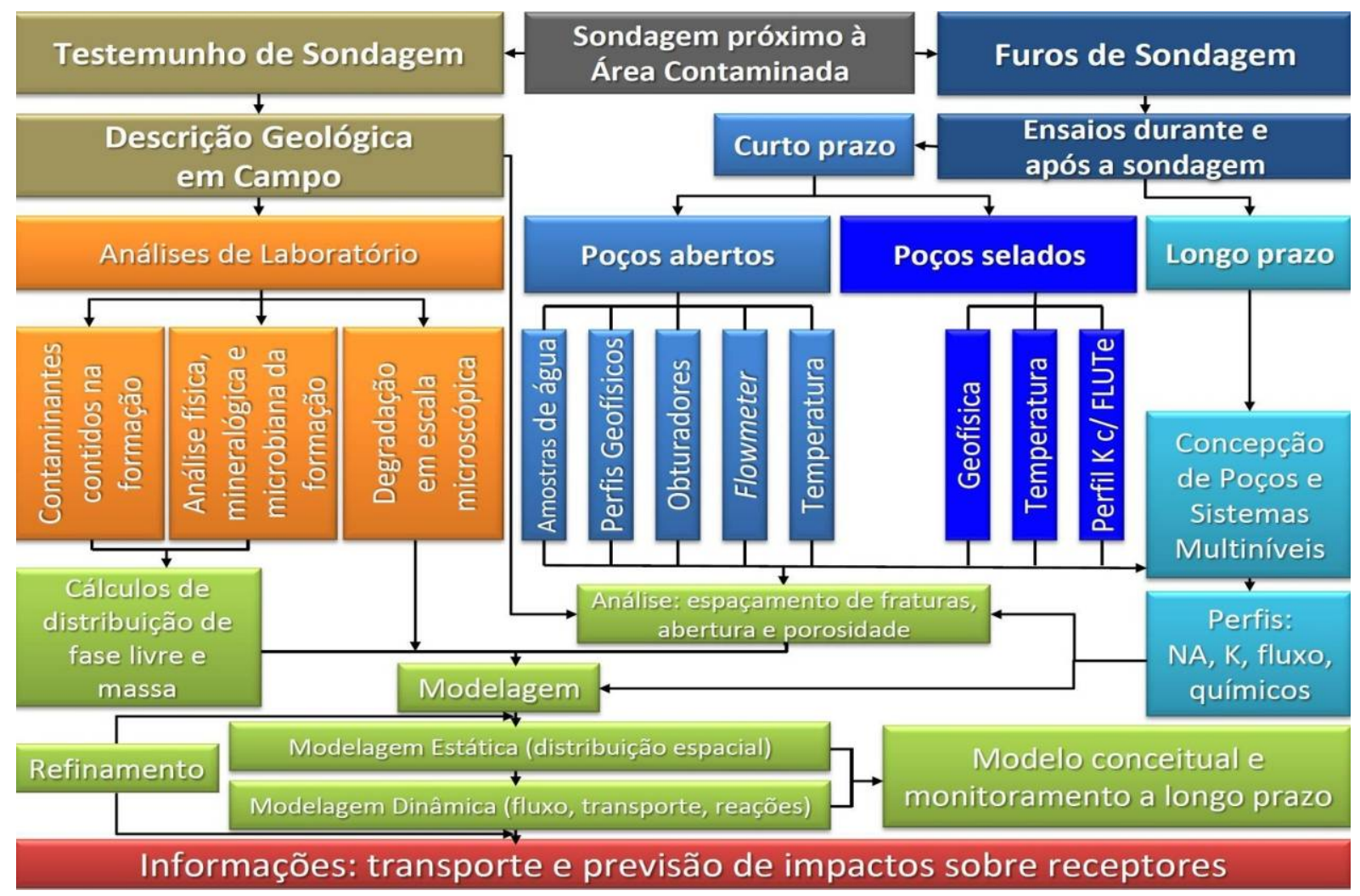

Figura 17 - Síntese do método Discrete Fracture Network (Parker, 2007).

As categorias de atividades de campo que constituem o método são $(i)$ perfuração e ensaios em testemunhos de sondagem; (ii) perfilagens geofísicas nos furos de sondagem; (iii) ensaios hidráulicos com obturadores nos furos de sondagem; e (iv) instalação de poços multiníveis, seguido de monitoramento de cargas, ensaios hidrálicos e monitoramento de qualidade da água. Elas são detalhadas a seguir.

\subsubsection{Perfuração e Ensaios em Testemunhos de Sondagem}

A locação da perfuração normalmente ocorre em áreas próximas à fonte de contaminação e em alguma posição que pode ser interessante do ponto de vista geológico, definido nos trabalhos anteriores de levantamento geológico-estrutural e de geofísica de superfície. A perfuração ocorre com recuperação de testemunhos de sondagem, que são fotografados e tem descritas as litologias e as estruturas. Diversas amostras são selecionadas do testemunho para análises químicas, a fim de se determinar a distribuição do contaminante na matriz da rocha e análises físicas para determinar suas propriedades hidráulicas, como porosidade, densidade, fração de carbono orgânico, difusividade a contaminantes e permeabilidade ao ar, determinações estas necessárias 
para obter informações sobre retardação e difusão de contaminantes na matriz. A amostragem é realizada com uma frequência média de três amostras por metro (Parker, 2012).

Esta etapa do método DFN para cálculos de distribuição massa de contaminantes orgânicos em diferentes rochas sedimentares foi aplicada por alguns autores (Meyer, 2005; Kennel, 2008). Identificou-se que grande parte da massa remanescente de contaminação encontra-se dentro da matriz dos aquíferos investigados, com concentrações indicativas da presença de NAPL. Nestes trabalhos, os autores definem os horizontes de coleta de amostras sempre próximas (acima e abaixo) de fraturas ou de contatos litológicos, que possam representar diferenças nos valores de condutividade hidráulica horizontal.

Como normalmente a perfuração é executada em área contaminada, a fim de se impedir a migração da água subterrânea contaminada de uma fratura para outra no aquífero, ocasionada pela realização da perfuração (Cherry et al. 2007), lonas impermeáveis do tipo FLUTe Liner (Keller, 2004) são utilizadas para selar temporariamente o furo de sondagem. Com o poço revestido pela lona, perfilagens de temperatura de alta resolução podem ser realizadas para detectar fraturas com circulação de água (Pehme et al. 2007a, 2010). Quando a lona é retirada, outras técnicas de perfilagens podem ser realizadas, como acústica, óptica, calibre e gama, além de testes hidráulicos com medidores de fluxo (flowmeter) e sistemas de obturadores de pressão.

\subsubsection{Perfilagens Geofísicas}

Perfilagens geofísicas da parede de sondagens e poços auxiliam na definição de suas condições construtivas e na identificação da litologia, estratigrafia e fraturas (Keys 1990; Lane 2002). As sondas mais comumente utilizadas para perfilagens geofísicas são as de temperatura e condutividade elétrica, calibre, imageamentos acústico e ótico, gama natural e flowmeter (Morin et al., 1997). Historicamente, observa-se que é a combinação de diversas ferramentas que permite avaliações mais precisas dos aspectos estruturais, litológicos e hidráulicos do meio, independentemente do contexto geológico. Estes dados podem também ser utilizados para validar ou complementar em profundidade as observações feitas em afloramentos (Morin et al., 2007). Em geral, há uma boa conformidade entre os dados de perfilagens geofísicas em poços e os dados de superfície, indicando que essa fusão de informações é efetiva para a definição de modelos geológicos.

- Imageamentos ótico e acústico

Dentre os métodos de perfilagem em escalas de investigação de maior detalhe, destacam-se 
os imageamentos ótico e acústico. São amplamente utilizados na obtenção das atitudes das principais fraturas que interceptam o poço. $\mathrm{O}$ imageamento ótico apresenta como principais aplicações o levantamento de imagens de alta resolução e complementam as informações de perfis de sondagem e descrição de testemunhos. Sua principal limitação é o encobrimento de fraturas, que apesar de pouco abertas podem apresentar alta condutividade hidráulica (Lane et al., 2002). Por outro lado, o imageamento acústico pode suprir essa necessidade, uma vez que auxilia na caracterização do preenchimento das fraturas.

\section{- Flowmeter}

Para a aquisição de dados de fluxo de água subterrânea na perfuração, utiliza-se um perfilador denominado flowmeter para a medição do sentido e velocidade do fluxo vertical de água. O perfilador do tipo heatpulse flowmeter permite uma leitura com precisão, uma vez que identifica, através de pulsos de calor, as entradas e saídas de água no poço. Alguns parâmetros hidráulicos como transmissividade e condutividade hidráulica podem também ser avaliados com as perfilagens geofísicas de fluxo (Paillet 1998, 2000; Day-Lewis et al. 2011; Johnson et al., 2011).

A identificação das zonas hidraulicamente ativas são de grande interesse pois determinam as profundidades discretas nas quais serão realizados os ensaios com obturadores e demais ensaios hidráulicos. Como o diâmetro do poço pode influenciar no cálculo do fluxo vertical obtido pelo flowmeter, Wahnfried (2010) e Pehme et al. (2010) destacam a importância de realizar conjuntamente as perfilagens de diâmetro de poço (caliper) e/ou imageamentos das paredes do poço (BHTV) para interpretar os dados do flowmeter.

- Perfilagem de temperatura

A sonda ALS foi desenvolvida na Universidade de Guelph (Canadá) e realiza perfilagem de temperatura em alta resolução $\left( \pm 0.001^{\circ} \mathrm{C}\right)$ em furos selados pelas lonas impermeáveis FLUTe. Possui, portanto, maior sensibilidade na identificação de fraturas do que os métodos convencionais, além de representar as condições ambientes da formação (Pehme et al. 2007).

O método de perfilagem ALS tem sido empregado em aquíferos de rochas sedimentares para a identificação de fraturas transmissivas e fornecendo resultados promissores, permitindo identificar o dobro de fraturas hidraulicamente ativas em comparação aos ensaios em furos abertos (Pehme 2012; Pehme et al. 2007, 2013). Outra vantagem do método é que ele pode ser empregado em áreas contaminadas, uma vez que a perfilagem é feita com o furo selado por membrana flexível (Pehme et al. 2007). 


\subsubsection{Ensaios Hidráulicos}

- Ensaios hidráulicos com obturadores

Uma vez definida a presença de fraturas hidraulicamente ativas, mapeadas nas perfilagens geofísicas, ensaios hidráulicos com uso de obturadores de pressão são realizados ao longo do furo de sondagem, objetivando a obtenção de parâmetros hidráulicos (condutividade hidráulica, transmissividade, abertura hidráulica da fratura e porosidade de fraturas) de diferentes trechos da rocha fraturada. O emprego da técnica para estes fins é apresentado por uma série de autores (Lapcevic 1988; Novakowski 2000; Wahnfried 2010; Quinn et al. 2011a, 2011b, 2012, dentre outros).

O procedimento geral é o de isolamento com obturadores de um intervalo de teste o mais discreto possível na perfuração. A água é entao injetada ou bombeada e o fluxo e as pressões são mensuradas acima, entre e abaixo dos obturadores. Quatro tipos de ensaios são normalmente realizados: carga constante (escalonado), slug test, bombeamento e recuperação. O objetivo principal é a determinação dos melhores valores possíveis de transmissividade, que serão utilizados para o cálculo da abertura hidráulica equivalente das fraturas e estimar velocidades de fluxo da água subterrânea. O método de análise dos dados obtidos em campo estão sumarizados na Figura 18 (Quinn et al., 2012).

\section{- Ensaios hidráulicos com FLUTe Liner}

Em paralelo à utilização de obturadores e mesmo de flowmeters para a aquisição de informações hidráulicas de fraturas em poços, a lona FLUTe blank liner pode também ser utilizada para a obtenção de dados de transmissividade de fraturas (Keller, 2004; Cherry et al. 2007; Quinn et al. 2012). O procedimento requer a introdução de água no liner, que desenrola-se dentro da perfuração, empurrando a água do furo de volta para as fraturas da rocha (Figura 19). A velocidade de descida da lona é medida, aumentando em zonas mais permeáveis. Os dados são interpretados em seguida, procurando-se correlacionar a velocidade de deslocamento com medidas de transmissividade. 


\begin{tabular}{|c|c|c|c|c|c|c|}
\hline Ensaio & $\begin{array}{l}\text { Resultado } \\
\text { do ensaio }\end{array}$ & $\begin{array}{l}\text { Método de } \\
\text { Interpretação }\end{array}$ & $\begin{array}{l}\text { Análise dos } \\
\text { resultados }\end{array}$ & $\begin{array}{l}\text { Pressão } \\
\text { e vazão }\end{array}$ & Vantagem & Diferencial \\
\hline $\begin{array}{l}\text { Carga } \\
\text { Constante }\end{array}$ & $\mathrm{T}$ & $\begin{array}{l}\text { Thiem } \\
T=\frac{Q}{2 \pi \Delta H} \ln \left(\frac{r_{o}}{r_{w}}\right)\end{array}$ & 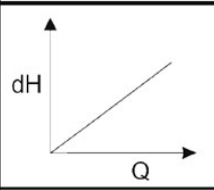 & $\begin{array}{l}\text { Carga e vazão } \\
\text { Constantes }\end{array}$ & $\begin{array}{l}\text { Validação } \\
\text { do fluxo } \\
\text { de Darcy }\end{array}$ & $\begin{array}{l}\text { Identifica } \\
\text { o limite do } \\
\text { fluxo de } \\
\text { Darcy }\end{array}$ \\
\hline Slug Bail & $\stackrel{V \text { Ball }}{\longrightarrow}$ & $\begin{array}{l}\text { Hvorslev (Radial flow) } \\
T=\frac{m\left(A_{x s}\right)}{2 \pi} \ln \left(\frac{r_{o}}{r_{w}}\right)\end{array}$ & $\ln (-$ & $\begin{array}{l}\text { Carga e } \\
\text { vazão } \\
\text { variam }\end{array}$ & $\begin{array}{l}\text { Ensaio } \\
\text { rápido }\end{array}$ & $\begin{array}{l}\text { Identifica falha } \\
\text { no selo e } \\
\text { desenvolve o } \\
\text { poço }\end{array}$ \\
\hline $\begin{array}{l}\text { Bombea- } \\
\text { mento }\end{array}$ & $\mathrm{H}$ & $\begin{array}{l}\text { Cooper-Jacob } \\
\text { Straight Line } \\
\text { Method } \\
\qquad T=\frac{2.3 Q}{4 \pi \Delta s}\end{array}$ & 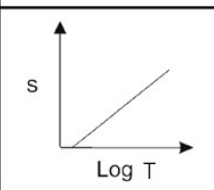 & $\begin{array}{l}\text { Vazão } \\
\text { constante e } \\
\text { carga variável }\end{array}$ & $\begin{array}{l}\text { Ensaio com } \\
\text { grande raio } \\
\text { de influencia }\end{array}$ & $\begin{array}{l}\text { Identifica } \\
\text { efeitos de } \\
\text { porosidade } \\
\text { dupla }\end{array}$ \\
\hline $\begin{array}{l}\text { Recuperação } \\
\text { após o } \\
\text { Bombea- } \\
\text { mento }\end{array}$ & $\mathrm{H}$ & $\begin{array}{l}\text { Theis Recovery } \\
\text { Method } \\
\qquad T=\frac{2.3 Q}{4 \pi \Delta s^{\prime}}\end{array}$ & $\log t / t^{\prime}$ & $\begin{array}{l}\text { Carga e } \\
\text { vazão } \\
\text { variam }\end{array}$ & $\begin{array}{l}\text { Ensaio com } \\
\text { grande raio } \\
\text { de influencia }\end{array}$ & $\begin{array}{l}\text { Identifica } \\
\text { efeitos de } \\
\text { porosidade } \\
\text { dupla }\end{array}$ \\
\hline \multicolumn{2}{|c|}{$\begin{array}{l}T=\text { Transmissividade } \\
\mathrm{Q}=\text { Vazão } \\
\mathrm{r}_{\mathrm{w}}=\text { Raio do poço } \\
\mathrm{r}_{\mathrm{o}}=\text { Raio de influência }\end{array}$} & $\begin{array}{l}\text { Rebaixamento } \\
\text { Rebaixamento residual } \\
\text { Área da seção do tubo } \\
\text { central }\end{array}$ & $\begin{array}{l}\mathrm{dH}=\text { Carg } \\
\Delta \mathrm{H}_{\circ}: \text { Carg } \\
\Delta \mathrm{H}=\text { Carg } \\
\mathrm{m}=\text { Âng }\end{array}$ & $\begin{array}{l}\text { aplicada } \\
\text { aplicada inicial } \\
\text { aplicada no temr } \\
\text { o da reta }\end{array}$ & & \\
\hline
\end{tabular}

Figura 18 - Tipos de ensaios hidráulicos realizados com obturadores e métodos de obtenção de valores de transmissividade (modificado de Quinn, 2012)

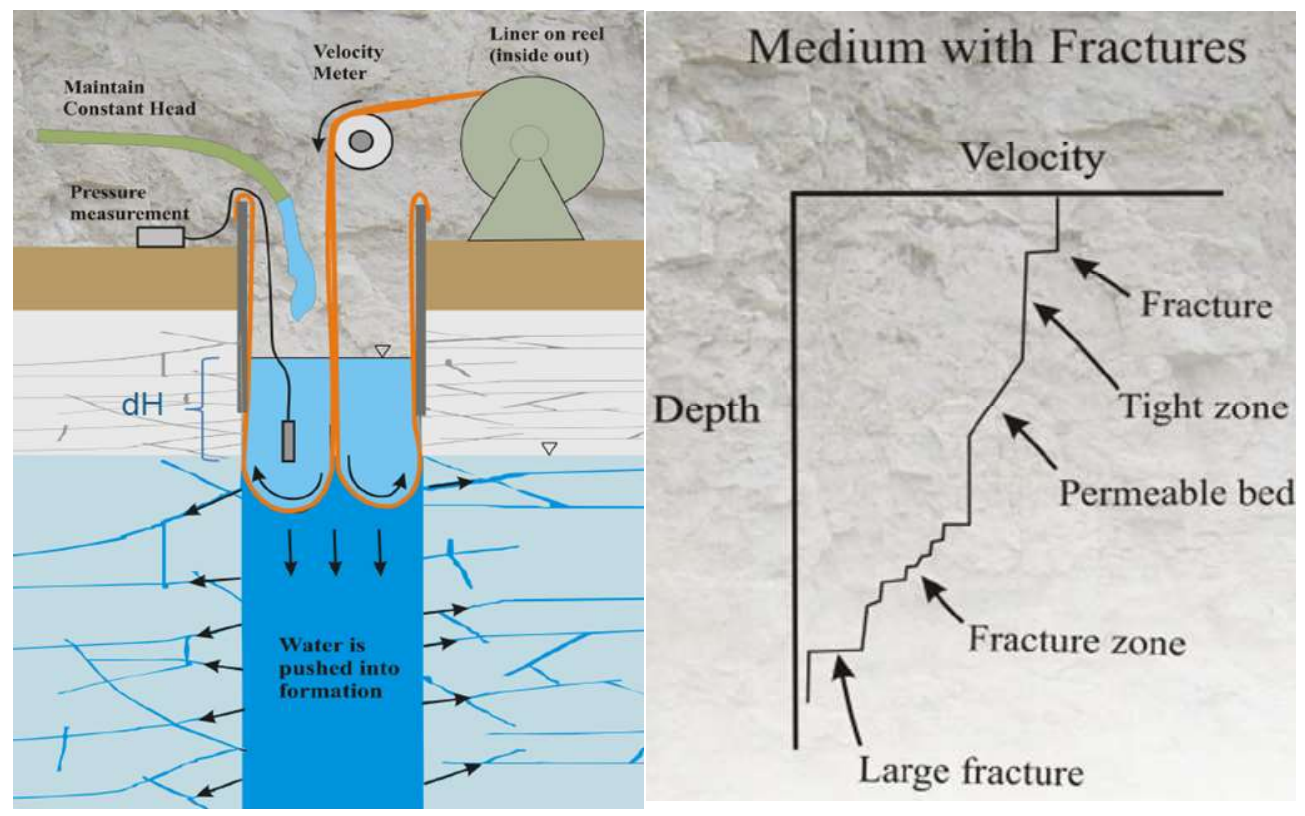

Figura 19 - Ensaios hidráulicos com FLUTe blank liner (Keller, 2004) 
- Ensaios hidráulicos cross-borehole

Ensaios do tipo cross-borehole são um método para fornecer informações sobre as conexões hidráulicas entre fraturas em aquíferos fraturados (Novakowski et al. 2006; Williams et al. 2007; Levison \& Novakowski 2012; Paillet et al. 2012). Esses testes consistem na aplicação de uma condição de estresse em um poço e no monitoramento dos efeitos em poços adjacentes, denominados poços de observação. Obturadores podem ser utilizados em poços de observação ou no poço que proporciona o estresse de carga, assim como o sistema de poços multiníveis também pode ser utilizado para tal. Estes ensaios incluem diversas técnicas, entre as quais se destacam: (i) injeção de traçador em poços com fratura única ou em zonas de fraturas e análise da concentração do traçador que atinge os poços de observação (Novakowski et al. 2006; Levison \& Novakowski 2012); (ii) bombeamento de poços interceptando fraturas e monitoramento de cargas hidráulicas e fluxo no poço de observação (Paillet 1998; Williams \& Paillet 2002; Le Borgne et al. 2006; Williams et al. 2007).

\subsubsection{Sistema de Poços Multiníveis}

Após as perfilagens geofísicas e testes hidráulicos, os trechos de maior interesse nas perfurações são definidos para a instalação do sistema de monitoramento multinível, utilizados para a obtenção de informações de carga hidráulica, realização de ensaios hidráulicos e obtenção de amostras de água de fraturas discretas para análises. De acordo com a metodologia DFN, os sistemas de monitoramento multinível devem ser do tipo alta resolução, significando um considerável número de portas de monitoramento instalados numa única perfuração, permitindo monitorar as cargas hidráulicas e realizar coleta de amostras de água subterrânea em escala de superdetalhe.

Existem ao menos dois principais sistemas modernos de poços multiníveis disponíveis: FLUTe Multilevel System, que comporta em média 12 portas de monitoramento de carga hidráulica e amostragem de água, e o Westbay System, que não tem limite para o número de portas de monitoramento. Diversos estudos de caso de medições de carga hidráulica e concentração de contaminantes em zonas de monitoramento discretas são apresentados por Einarson \& Cherry (2002). Os estudos demonstram a vantagem do uso de dados hidráulicos e de qualidade de água obtidos a partir de sistemas multiníveis de alta resolução em relação aos sistemas multiníveis convencionais.

Meyer et al. (2008) apresentam a aplicação de medições de carga hidráulica em poços de 
monitoramento tipo Westbay para o reconhecimento de unidades hidroestratigráficas em um aquífero de rocha sedimentar fraturada. Os autores utilizam diversas zonas de monitoramento de carga hidráulica ao longo da seção vertical do aquífero monitorado e correlacionam as variações verticais de carga hidráulica com as informações provenientes de ensaios geofísicos e de ensaios com obturadores de pressão para elaboração de um modelo conceitual de fluxo da área de estudo.

\section{Capítulo 3 - Investigações Realizadas em Jurubatuba, São Paulo}

A região do Canal do Jurubatuba apresenta uma situação bastante complexa em termos ambientais. Trata-se de uma região de uso predominantemente industrial desde a década de 1950, com intensa exploração de água subterrânea através de poços profundos e que hoje passa por uma forte transformação do uso do solo, para comercial e residencial. Várias das indústrias instaladas fizeram uso de solventes organoclorados em seus processos industriais e contaminações do solo e da água subterrânea ocorreram em vários locais em decorrência do manuseio não apropriado destas substâncias. A CETESB registra 17 áreas contaminadas por compostos etenos clorados na região (Figura 20) (L'Apiccirella, 2009).

A associação da possível existência de fase livre densa não-aquosa nas áreas contaminadas com os fortes potenciais hidráulicos verticais descendentes provocados pelo intenso bombeamento dos poços de abastecimento, possibilitaram o transporte destas substâncias a profundidades de várias dezenas de metros no interior do aquífero fraturado da região. Como consequência, dezenas de poços de abastecimento registrados no DAEE apresentaram-se contaminados (Figura 20), tendo sido posteriormente interditados pelo Poder Público em meados da década passada. Em seguida, uma zona de restrição de bombeamento foi estabelecida no local pelos órgãos gestores da água subterrânea (São Paulo, 2009; L’Apiccirella, 2009).

Cálculos simples indicam que os prejuízos econômicos gerados pela restrição de acesso à água subterrânea através dos poços interditados neste local chegam à ordem de milhões de reais por ano. Prejuízos de outras naturezas provavelmente estão associados ao problema ambiental, como os riscos à saúde humana gerados pela utilização da água subterrânea contaminada por usuários de poços ilegais e não cadastrados no DAEE, que estima-se ser da ordem de dezenas. 

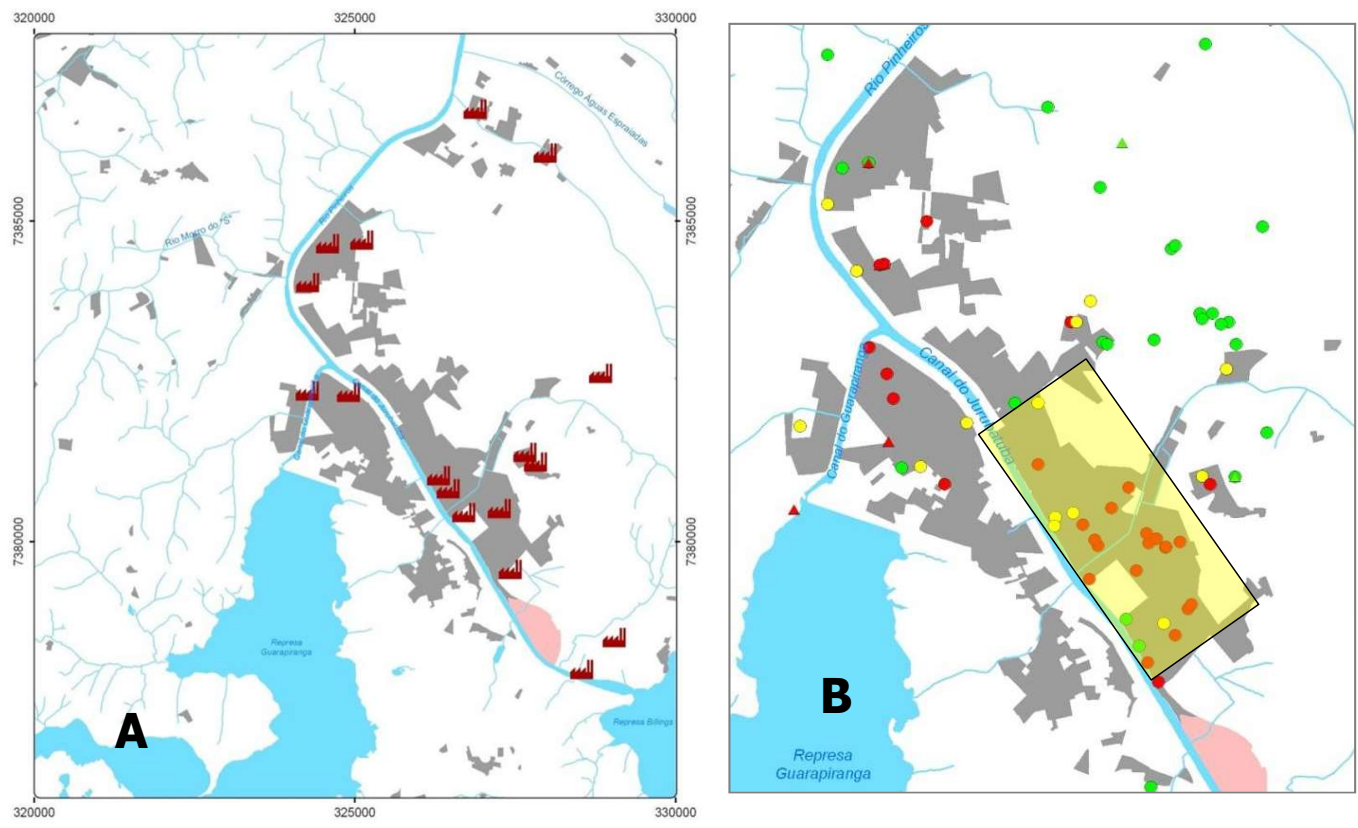

Figura 20 - (A) Localização de áreas contaminadas por compostos organoclorados e (B) poços profundos com deteç̧ão de VOCs (pontos vermelhos e amarelos) na região de Jurubatuba, distrito de Santo Amaro, São Paulo (L'Apiccirella, 2009). Em cinza, as áreas predominantemente industriais. Área em amarelo concentra as investigações deste projeto.

A CETESB vem realizando o gerenciamento individual das áreas contaminadas junto aos responsáveis legais destas áreas, porém as investigações ambientais se concentram nas porções rasas do aquífero sedimentar/manto de intemperismo e próximas das áreas fontes reconhecidas. As investigações sobre a intensidade e extensão dos impactos no aquífero fraturado profundo são limitadas, até porque não se tem uma noção precisa das responsabilidades pela contaminação nessas profundidades, que pode ter ocorrido pela superposição de plumas originadas de diferentes áreas fontes. Esta complexa situação fez com que a CETESB classificasse a região de Jurubatuba como uma área contaminada crítica, demandando a necessidade de um procedimento de gerenciamento diferenciado para a definição de estratégias de intervenção, de comunicação de risco e de gestão da informação.

Desde 2011 até o presente, o CEPAS-USP vem trabalhando num projeto que objetiva estabelecer as bases técnicas necessárias para a gestão de áreas contaminadas por solventes clorados em aquíferos fraturados, tendo a região de Jurubatuba como área de estudo. Este projeto tem como objetivos específicos: (1) entender a geologia e as suas estruturas rúpteis; (2) definir o modelo conceitual de fluxo da água subterrânea, as conexões hidráulicas das porções rasas e profundas do aquífero e os mecanismos de recarga do aquífero fraturado; (3) definir o modelo de 
transporte dos contaminantes, com o uso de técnicas químicas, isotópicas e biológicas; (4) desenvolver e adaptar tecnologias para o estudo de detalhe do fluxo de contaminantes; e (5) criar os protocolos para a gestão das áreas contaminadas em contexto de aquíferos fraturados.

As atividades desenvolvidas e as que se encontram em andamento para as definições dos modelos conceituais de geologia, de fluxo, reservação, transporte e destino dos contaminantes obedecem aos procedimentos descritos nos itens 2.3 e 2.4 acima. A abordagem envolveu a utilização de muitas tecnologias até então inéditas no Brasil, como o FLUTe Blank Liner e o sistema multinível Westbay. O método também consistiu na obtenção de análises químicas, isotópicas e microbiológicas de rocha e água subterrânea, inclusive com o uso de análises de isótopos de carbono e cloro para a avaliação de degradações e origens de plumas de solventes clorados.

As atividades realizadas e em execução estão relacionadas com os projetos de mestrado e doutorado de profissionais participantes da pesquisa, sob orientação predominante do autor desta tese. A área de estudo onde as investigações foram concentradas encontra-se destacada na Figura 20. Os itens a seguir descrevem as perguntas científicas relacionadas a cada projeto de pósgraduação, um resumo dos principais resultados obtidos até o momento.

\section{1 - Modelos Conceituais de Geologia e Hidrogeologia - Escalas Regional a Local}

Os trabalhos de desenvolvimento do modelo conceitual de geologia e hidrogeologia do aquífero fraturado de Jurubatuba nas escalas regional a local (bairro do Jurubatuba) relacionamse com os mestrados de Fiúme (2014) e Barbosa (2015) e com o doutorado de Barbosa (em andamento).

Fiúme (2014) investigou os aspectos de geologia estrutural em escalas regional e local. Os objetivos específicos deste trabalho foram: (i) caracterizar os principais grupos de fraturas, suas direções, mergulhos, comprimentos e espaçamentos; (ii) analisar dados de perfilagens de poços profundos para identificar as fraturas mais transmissivas; e (iii) identificar os eventos tectônicos que atuaram na região de estudo com o objetivo de compará-los com os eventos tectônicos mais recentes, descritos na literatura, e verificar se os grupos de fraturas hidraulicamente mais ativos são controlados pela atividade neotectônica e/ou pelo campo de esforços atual.

A metodologia utilizada para a investigação da geologia estrutural compreendeu a aplicação dos seguintes métodos: 1) análise de lineamentos traçados em escala local e regional; 
2) levantamento de fraturas, segundo scanlines e pontos, em afloramentos; 3) aplicação conjunta de diferentes perfilagens geofísicas (cáliper, gama natural, imageamentos ótico e acústico e flowmeter) em quatro poços profundos localizados na área de estudo.

Parte dos resultados obtidos encontram-se apresentados em detalhe no artigo exibido no Anexos 1 (Fernandes et al, 2016). Em síntese, o levantamento e análise estrutural realizados em quatro pedreiras e os dados coletados em poços no Jurubatuba resultaram na definição dos seguintes grupos mais importantes quanto à sua frequência e continuidade (em ordem decrescente): fraturas N0-50W conjugadas ou híbridas, geradas em evento transcorrente com $\sigma 1$ $\mathrm{N} 20-50 \mathrm{~W}$ (grupo 1); fraturas EW, extensionais, subverticais (grupo 2a), ou de cisalhamento a híbridas com mergulho de 60 a $70^{\circ}$ (grupos $2 \mathrm{~b}$ e $2 \mathrm{c}$ ), todas geradas durante regime tectônico de falhas normais com $\sigma 3$ de direção NS, correlacionável ao evento extensional que gerou a Bacia São Paulo; e NE, de grande espaçamento e mergulhos variando entre 60 e $90^{\circ}$ (grupo 3). Dentre os grupos de mergulhos baixos, destacam-se as fraturas N10-40E, com mergulhos de 10 a $30^{\circ}$ predominantemente para SE e subparalelas à foliação de gnaisses, sendo de pequeno espaçamento e grande extensão lateral (grupo 5b). A Figura 21 exibe o modelo conceitual do fraturamento mais relevante para o fluxo da água subterrânea na escala da área do Jurubatuba, indicando que as fraturas de baixo mergulho e paralelas à foliação (grupo 5b) são as mais importantes para o fluxo, juntamente com as do grupo 1, subverticais.

O modelo geológico conceitual da área de estudo foi complementado na dissertação de mestrado de Barbosa (2014), que, a partir da compilação e cadastro de mais de mil perfis litológicos de sondagens em um sistema geográfico de informações, realizou o mapeamento das espessuras de sedimentos terciários e do topo do embasamento cristalino na área foco da pesquisa no Jurubatuba (Figura 22 e Figura 23). 


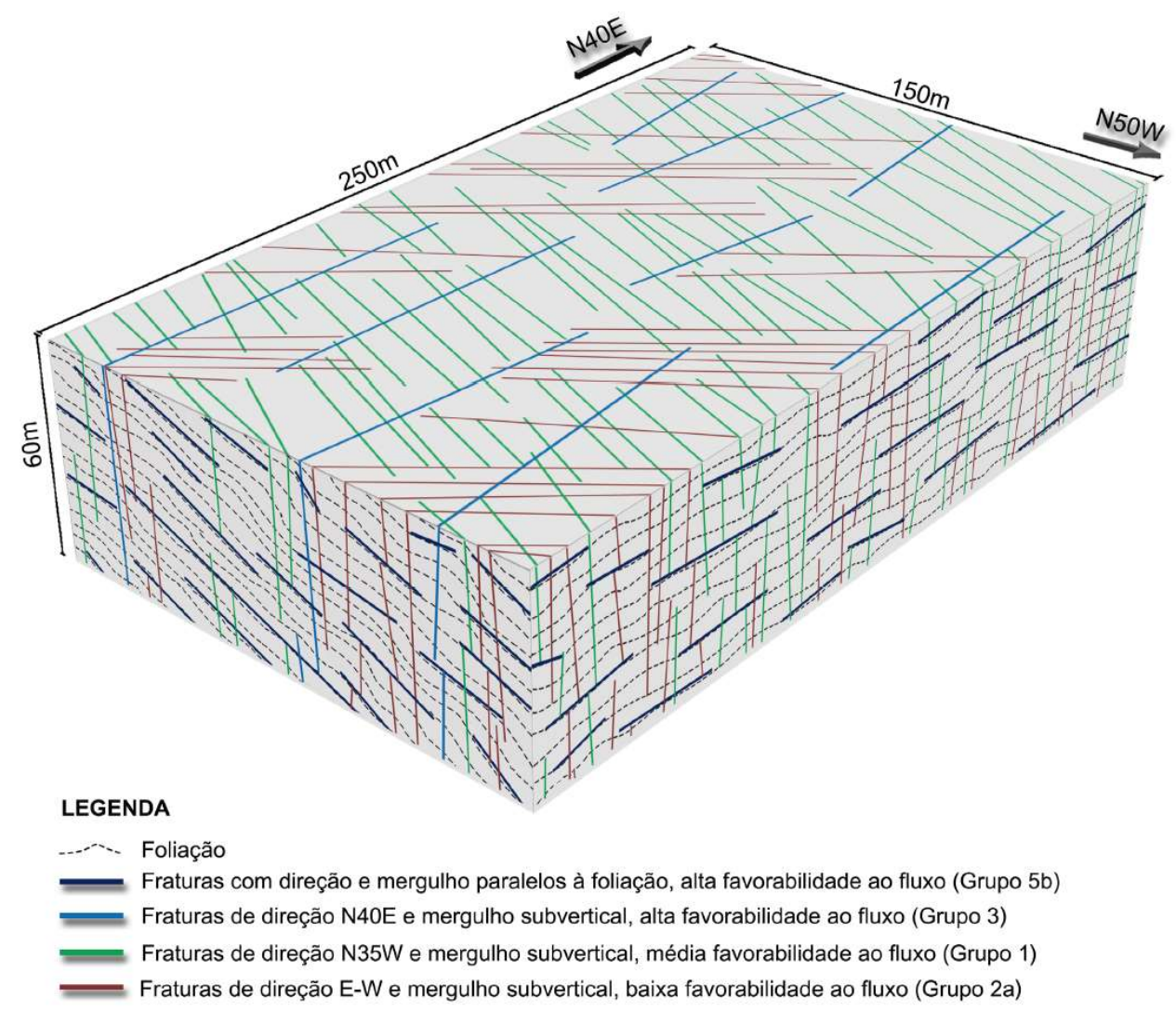

Figura 21 - Modelo geométrico de fraturas representando aquelas mais relevantes ao fluxo de água subterrânea na área do Jurubatuba.

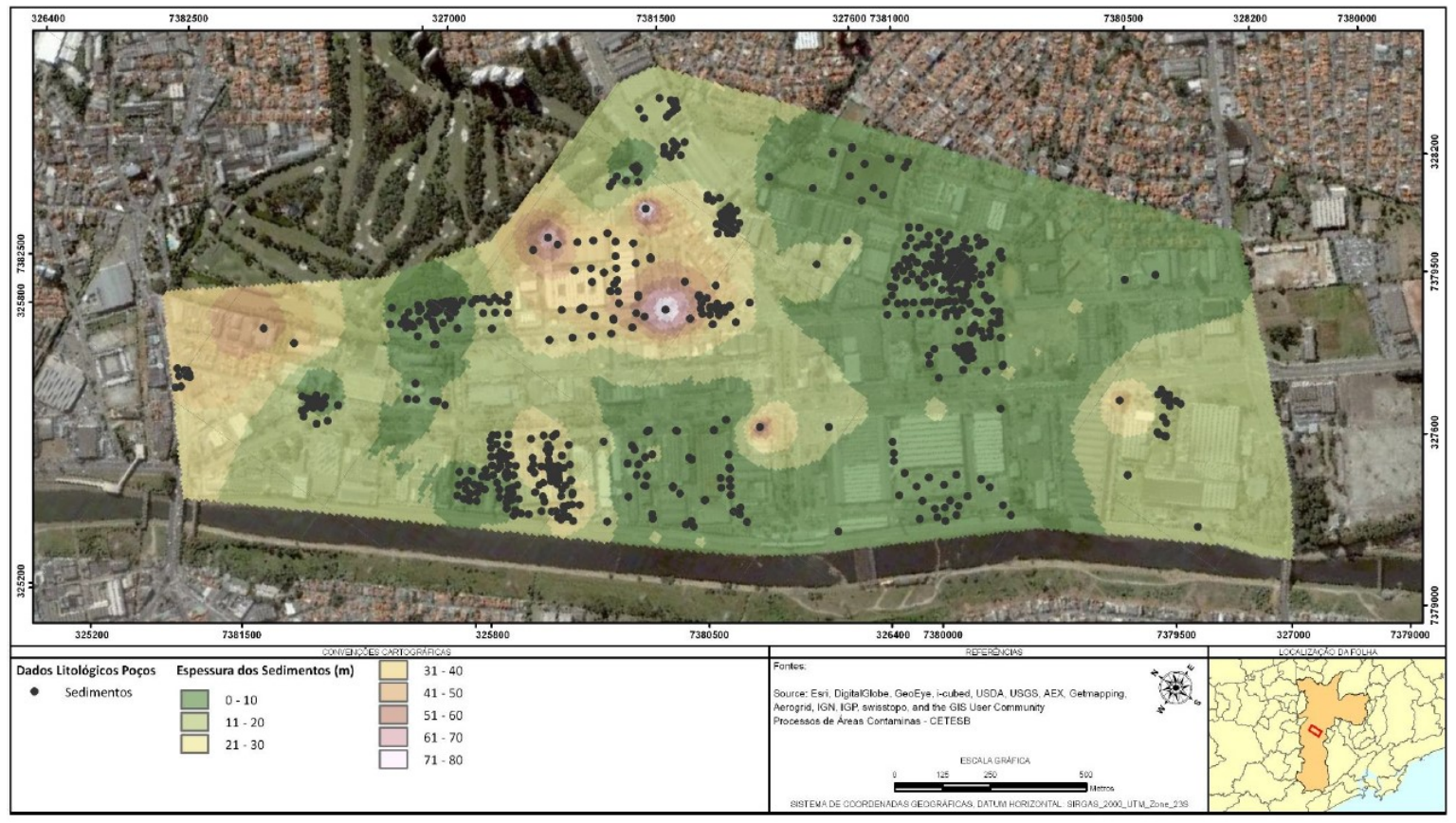

Figura 22 - Mapa de espessura de sedimentos terciários na área de Jurubatuba 


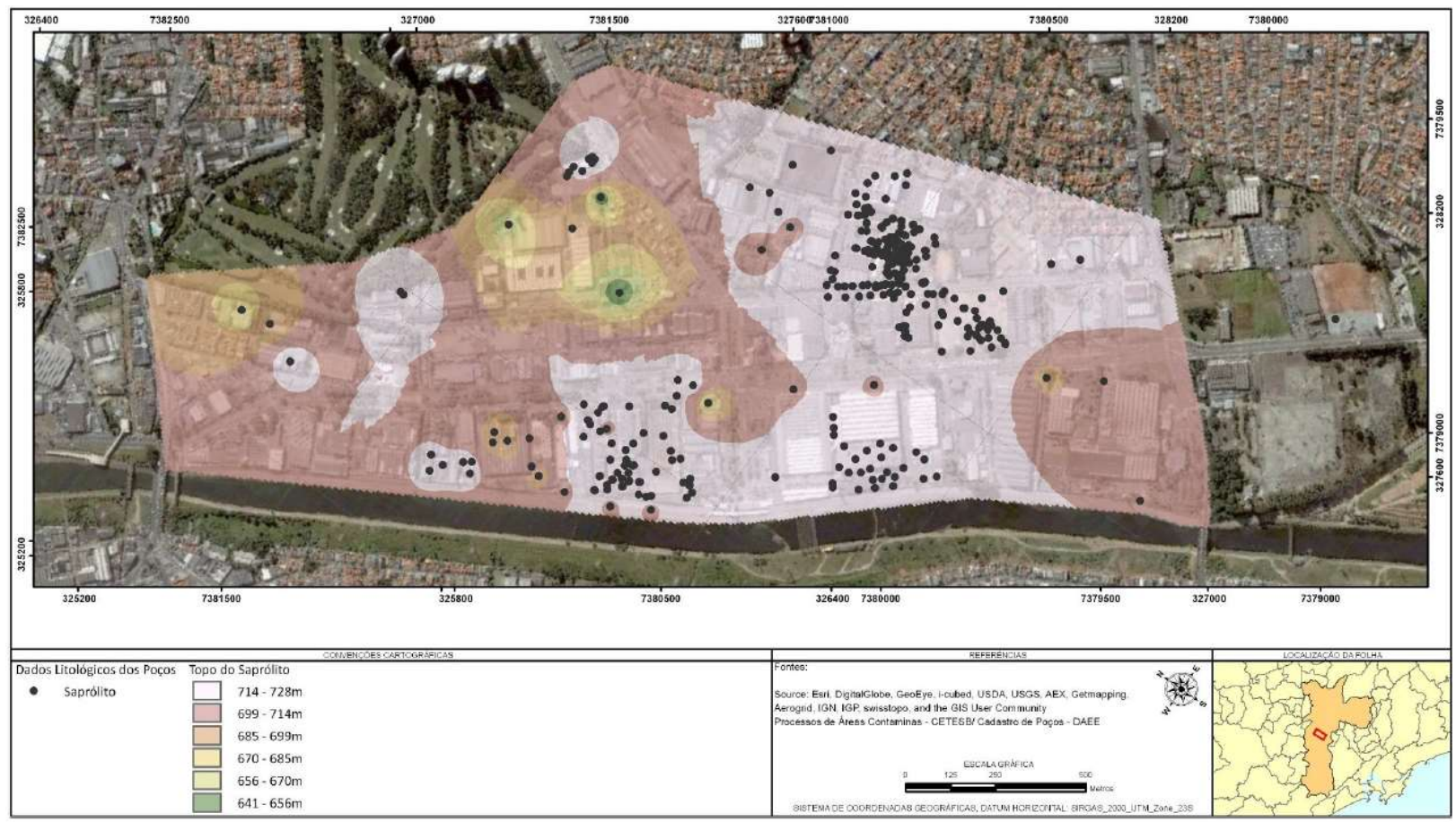

Figura 23 - Mapa de topo do embasamento cristalino na área de Jurubatuba

Barbosa (2015), em seu projeto de doutorado, vem utilizando uma série de ferramentas de investigação para ampliar o entendimento do modelo hidrogeológico conceitual na mesma área do Jurubatuba. Em ao menos sete poços profundos, com profundidades variando de 150 a 300 m, as seguintes atividades vem sendo realizadas: (i) filmagem com câmera de inspeção e perfilagens geofísicas (gama e acústica) para confirmar e ampliar o entendimento do modelo geológico definido por Fiúme (2014), (ii) perfilagens de detalhe com medidores de vazão (flowmeter) em condições normais e sob influência de bombeamento, objetivando identificar as fraturas mais transmissivas de cada poço; (iii) utilização de obturadores para isolar as fraturas mais interessantes e medir seus potenciais hidráulicos, a transmissividade de porções discretas e realizar coleta de amostras discretas de água subterrânea. As informações estão sendo coletadas no presente e são fundamentais para a possível realização de uma modelação matemática do aquífero na escala da área do Jurubatuba.

\section{2 - Modelos Conceituais de Geologia, Hidrogeologia e de Contaminação -}

\section{Escala de Superdetalhe}

Trabalhos de desenvolvimento do modelo conceitual de geologia, hidrogeologia e de contaminação do aquífero fraturado de Jurubatuba em escala de superdetalhe foram realizados 
próximos a uma área fonte de contaminação na propriedade da empresa Ergomat. As investigações relacionam-se com a utilização da técnica DFN (Parker et al., 2012) e uso de ferramentas de alta resolução. São objetivos específicos desta etapa do trabalho:

- Definir a forma como se dão as conexões hidráulicas entre os níveis aquíferos rasos e os níveis aquíferos fraturados profundos;

- Identificar a forma como se dá a reservação dos compostos etenos clorados nas porções de rocha alterada e de rocha sã (perfil de difusão dos contaminantes na rocha a partir das fraturas);

- Caracterizar o transporte destes compostos através das diferentes rochas; e

- Determinar a ocorrência e a intensidade do fenômeno de atenuação natural destas substâncias químicas.

Dois doutorados e um mestrado em andamento estão relacionados com estas atividades:

- Daphne Silva Pino. Caracterização de aquífero cristalino fraturado pelo método Discrete Fracture Network em zona tropical: caso da região de Jurubatuba;

- Paulo Lojkasek Lima. Utilização da metodologia DFN para o estabelecimento do modelo conceitual de transporte de compostos organoclorados no aquífero fraturado da região de Jurubatuba - São Paulo;

- Silvia Aparecida Molinas Ferreira. Processos microbiológicos associados à degradação de solventes halogenados na água subterrânea: biogeoquímica na área do Jurubatuba, São Paulo, SP.

Os itens a seguir descrevem as atividades que foram realizadas até o momento.

\subsubsection{Sondagens de Investigação}

O local escolhido para a realização de duas perfurações na rocha corresponde a uma área onde a água subterrânea apresenta-se contaminada por tetracloroeteno (PCE) e compostos de degradação. O local encontra-se na indústria Ergomat, onde poços de monitoramento registraram concentrações de PCE na ordem de vários $\mathrm{mg} / \mathrm{L}$ em profundidades próximas de $15 \mathrm{~m}$, onde ocorre a base do manto de intemperismo e o topo da rocha gnáissica dura.

As perfurações foram executadas para descrição litológica-estrutural de testemunhos e coleta de amostras de solo e rocha para análises químicas e físicas. Estas atividades são prérequisitos para a execução dos trabalhos de perfilagens geofísicas, ensaios hidráulicos com obturadores e instalação do sistema de monitoramento multinível (MLS). 
Um sistema de trados ocos helicoidais de diâmetro 10" foi inicialmente utilizado para a perfuração dos sedimentos e rocha alterada até o limite de alcance do equipamento, correspondente ao topo da rocha cristalina dura, atingido em 14,8 m. Após este ponto, o sistema de perfuração foi modificado para o rotativo com a utilização de coroas diamantadas e barriletes simples no diâmetro SWF (6"), até 16,2 m. Um revestimento de aço carbono de 5" de diâmetro foi instalado a $16,1 \mathrm{~m}$ para evitar desmoronamentos. $\mathrm{O}$ espaço anelar entre a perfuração e a coluna de revestimento foi cimentado e, após a cura da calda de cimento, prosseguiu-se com a perfuração em rocha por dentro do revestimento no diâmetro HWM (4”) até a profundidade de 60,13 m, com a utilização de barriletes do tipo duplo livre giratório, que permitem a recuperação contínua de testemunhos da rocha perfurada.

A Figura 24 apresenta o perfil esquemático da sondagem MP-01 realizada e a Figura 25 apresenta a sonda utilizada na perfuração. Durante toda a perfuração, buscou-se obter a maior recuperação possível de testemunhos, uma vez que estes são uma ferramenta essencial no método DFN.

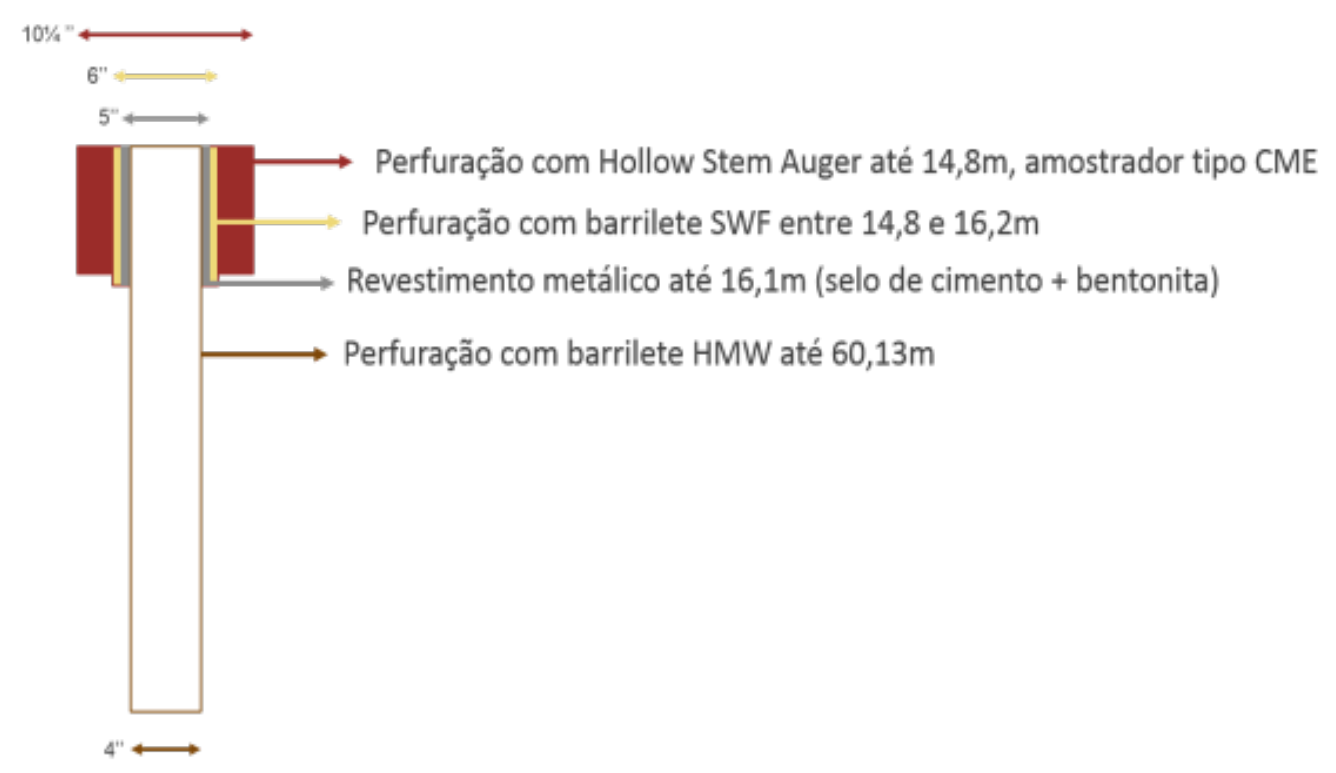

Figura 24 - Perfil esquemático do furo de sondagem MP-01. 


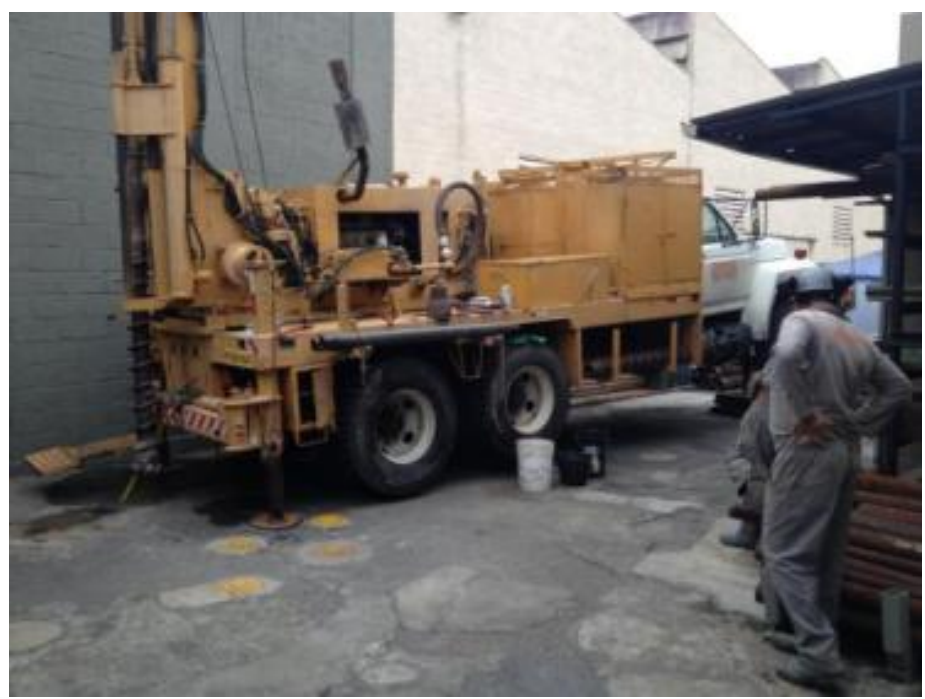

Figura 25 - Sonda utilizada na perfuração.

Apesar dos esforços para atingir o máximo de recuperação de amostras e o maior valor de RQD (Rock Quality Designation) possíveis, procedendo-se com a troca de barriletes e de amostradores, foi impraticável recuperar testemunhos no trecho entre 16,2 e 19,8 m, devido à alternância entre rochas alteradas moles e níveis mais resistentes (veios de quartzo). Novas alternativas foram estudadas para que pudesse ser atingido o padrão de recuperação de testemunhos desejado (aproximar recuperação e RQD de 100\%) em uma nova perfuração.

A segunda perfuração (furo de sondagem MP-01A), localiza-se a 1,5 m da primeira sondagem (MP-01). O objetivo desta nova perfuração foi de coletar amostras adicionais de rocha alterada/rocha para análise de propriedades físicas e químicas (para Compostos Orgânicos Voláteis), dando-se ênfase ao aumento da resolução de amostras ao longo do trecho de contato entre os horizontes de rocha alterada mole e rocha alterada dura, não recuperados de maneira eficiente na primeira perfuração.

Previamente à realização do trabalho de campo, foi desenvolvido, em parceria com a empresa de perfuração Engesolos, um sistema modificado de cravação de amostras, baseado na readaptação dos amostradores pitcher e barrilete duplo com coroa diamantada, comumente utilizados no mercado, assim como no sistema de circulação de água da perfuração. Originalmente, o amostrador pitcher possui uma coroa com dentes de videa, a qual foi modificada para um sistema de coroa com dentes de diamante que facilitasse a perfuração de material mais duro. 
Adicionalmente, o barrilete duplo, utilizado na primeira campanha de perfuração, também teve o design de sua coroa de perfuração modificada. Nessa etapa de perfuração, modificou-se o espaçamento e a disposição dos orifícios de injeção/saída de água utilizada para resfriamento da coroa, para que o mesmo minimizasse o contato da água de circulação e a amostra de rocha. Além disto, a bomba pistão, anteriormente utilizada para circulação de água foi substituída por uma bomba centrífuga, com o objetivo de diminuir a pressão de injeção.

Um sistema de trados ocos helicoidais de diâmetro 8/12" foi utilizado para perfuração até a cota de $12 \mathrm{~m}$, intercalando-se a cravação de um amostrador tipo shelby (Figura 26) e o amostrador tipo pitcher modificado (Figura 27) até a profundidade de 14,47 m. A partir desta cota, foi utilizado o barrilete duplo modificado (Figura 28) com diâmetro H, até a profundidade final de $20 \mathrm{~m}$. $\mathrm{O}$ furo foi revestido com revestimento $\mathrm{H}$ até a cota de 14,60 m.

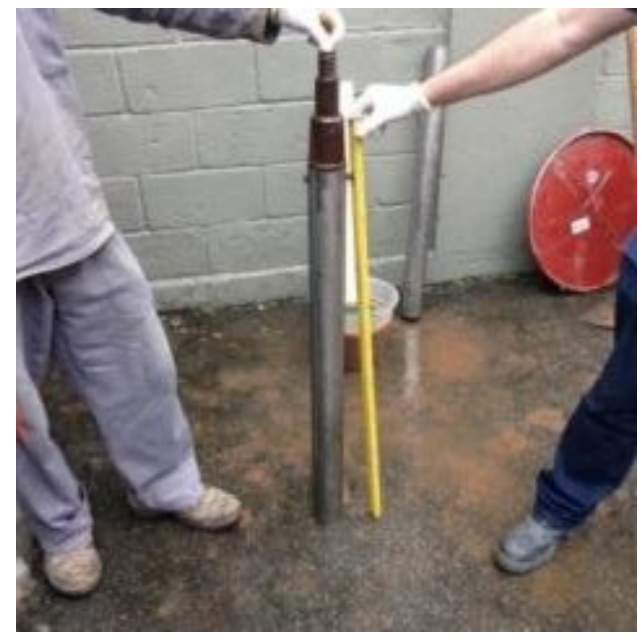

Figura 26 - Detalhe do amostrador tipo shelby.

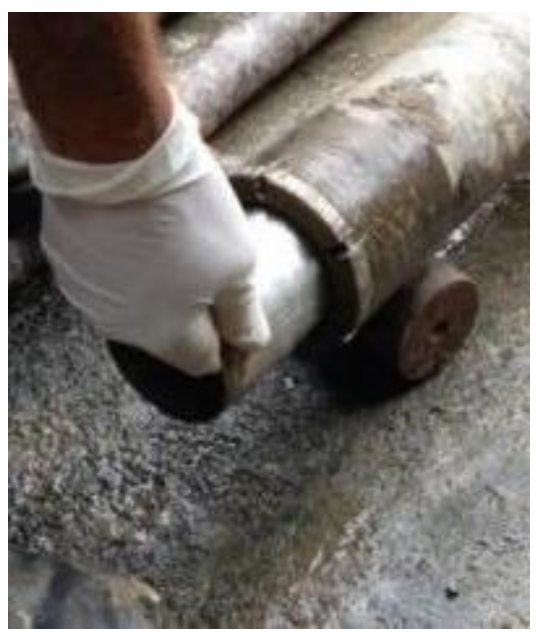

Figura 27 - Detalhe do amostrador pitcher modificado. Se observa o sistema de camisa interna e a coroa diamantada. 


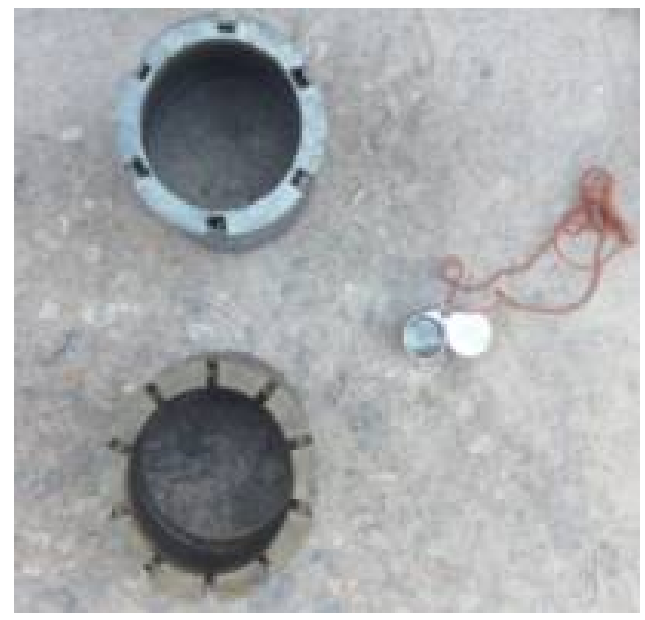

Figura 28 - Detalhe das

diferenças entre as coroas utilizadas nessa etapa de perfuração (parte de cima, coroa azul) e da campanha anterior (parte de baixo).

As amostras de rocha alterada coletadas nos amostradores shelby e pitcher eram extraídas dos amostradores de forma semi-indeformada e encaminhadas à primeira estação de trabalho para a descrição geológica e coleta de amostras para análise química. Na segunda perfuração, os procedimentos utilizados garantiram uma substancial melhora na recuperação dos testemunhos, próximo de 100\% nos trechos de interesse (Figura 29).

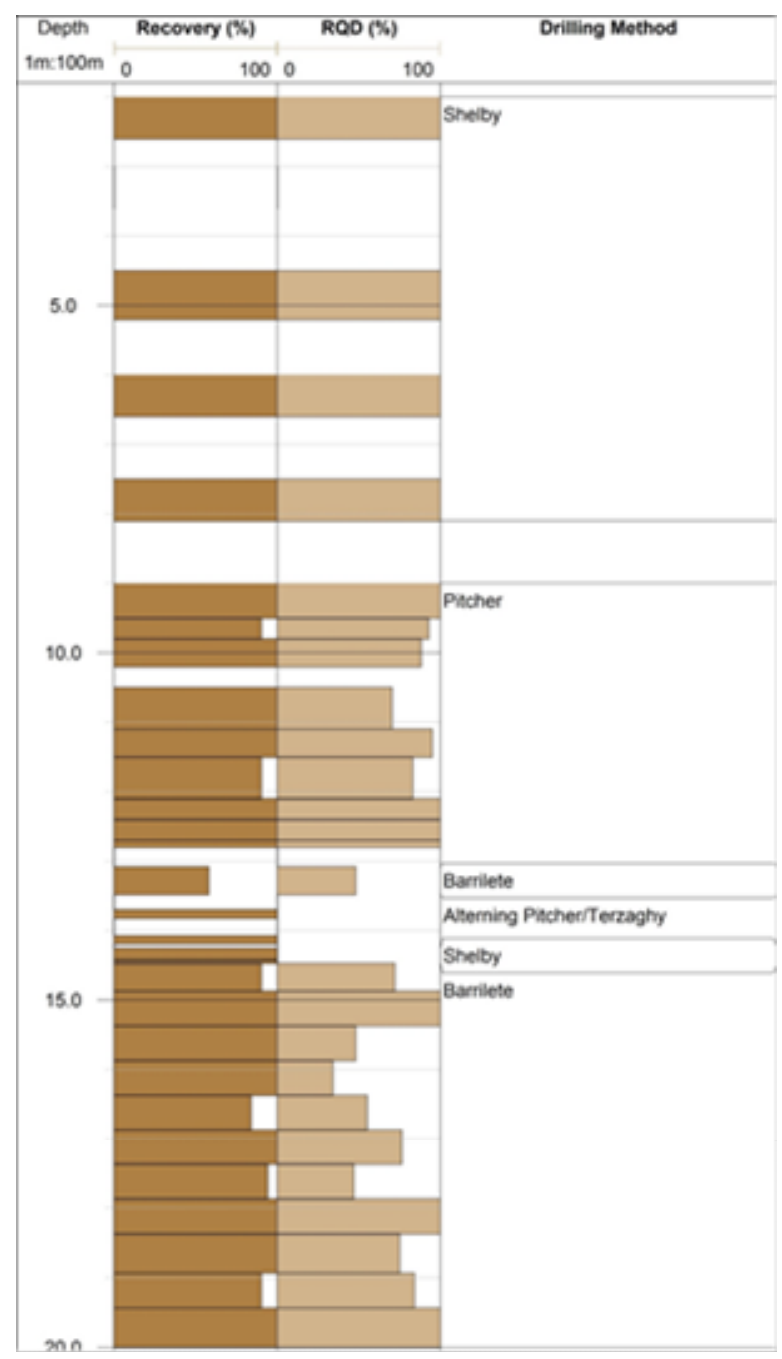

Figura 29 - Perfil de recuperação e RQD da segunda perfuração 


\subsubsection{Descrição de testemunhos e coleta de amostras de solo e rocha}

Os testemunhos retirados das perfurações foram manuseados em três estações de trabalho (Figura 30): (i) descrição litológico-estrutural e coleta de amostras, (ii) estúdio fotográfico, e (iii) triturador de amostras.

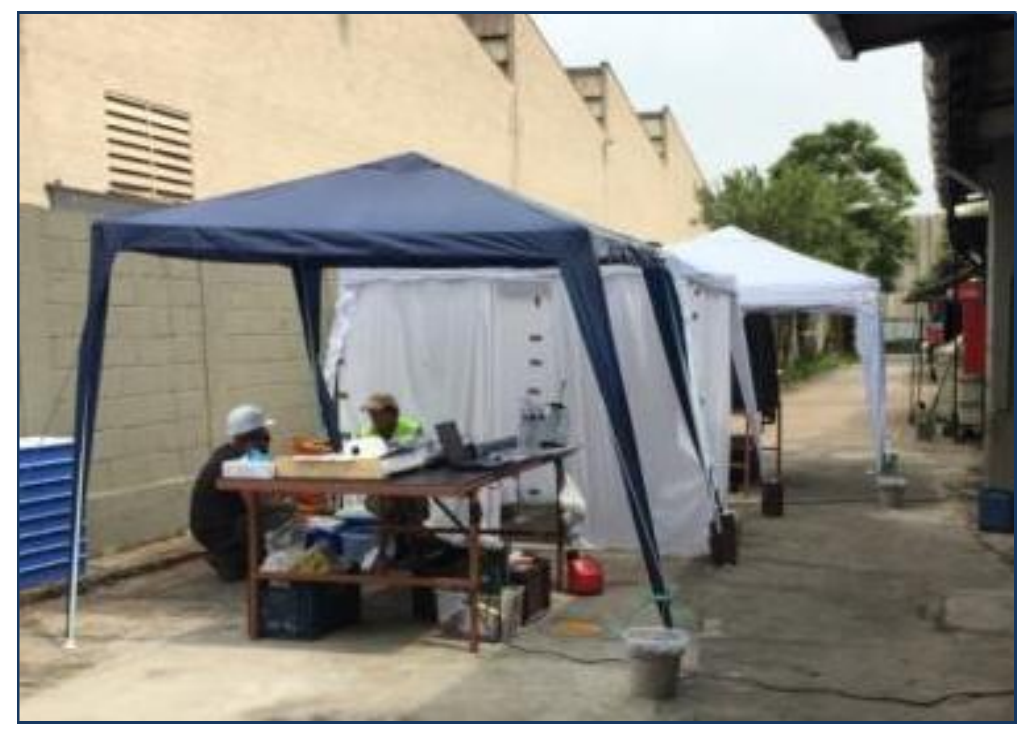

Figura 30 - Visão geral das estações de tratamento dos testemunhos: (i) no gazebo azul, a estação de descrição e coleta de amostras, (ii) no primeiro gazebo branco, fechado por cortinas, o estúdio fotográfico, (iii) no segundo gazebo branco (aberto, ao fundo), a do triturador de amostras.

Os testemunhos de rocha eram inicialmente levados para a estação de descrição, onde eram embalados em papel alumínio para evitar a perda de compostos voláteis. Em seguida, eram encaminhados para a segunda estação, do estúdio fotográfico (Figura 31a), a fim de ser realizado um registro em alta definição do testemunho conforme ele foi coletado (Figura 31b). O estúdio fotográfico é fechado por cortinas brancas a fim de homogeneizar a luz incidindo sobre o testemunho. Ademais, foram utilizadas cartas fotográficas de cores que possibilitaram a posterior correção da luz das imagens (Figura 31b).

Após a obtenção das fotografias, os testemunhos eram levados novamente à primeira estação (Figura 32). A descrição dos testemunhos de sondagem era realizada em relação a aspectos estruturais, mineralógicos, texturais e granulométricos. Concomitantemente, eram selecionadas amostras para análise química, coletadas com uma frequência mínima de 3 amostras por metro, incrementada sempre que necessário. A seleção ocorreu em função de variações litológicas e granulométricas e da presença de estruturas rúpteis até 16,2 m, e essencialmente em função das estruturas rúpteis no intervalo de 16,2 a 60,13 m. 


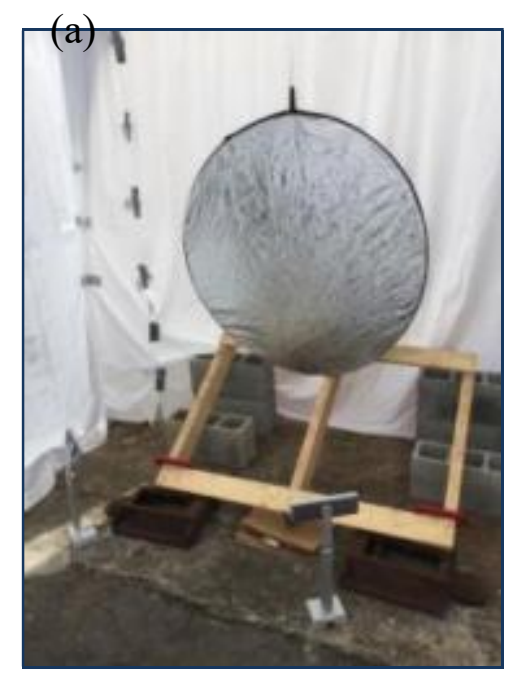

Figura 31 - (a) Interior da segunda estação: estúdio fotográfico. Notam-se as cortinas brancas e o refletor para homogeneizar a luz incidente e o suporte para a bandeja de testemunho. (b) Fotografia de testemunho de sondagem retirada na estação do estúdio fotográfico.
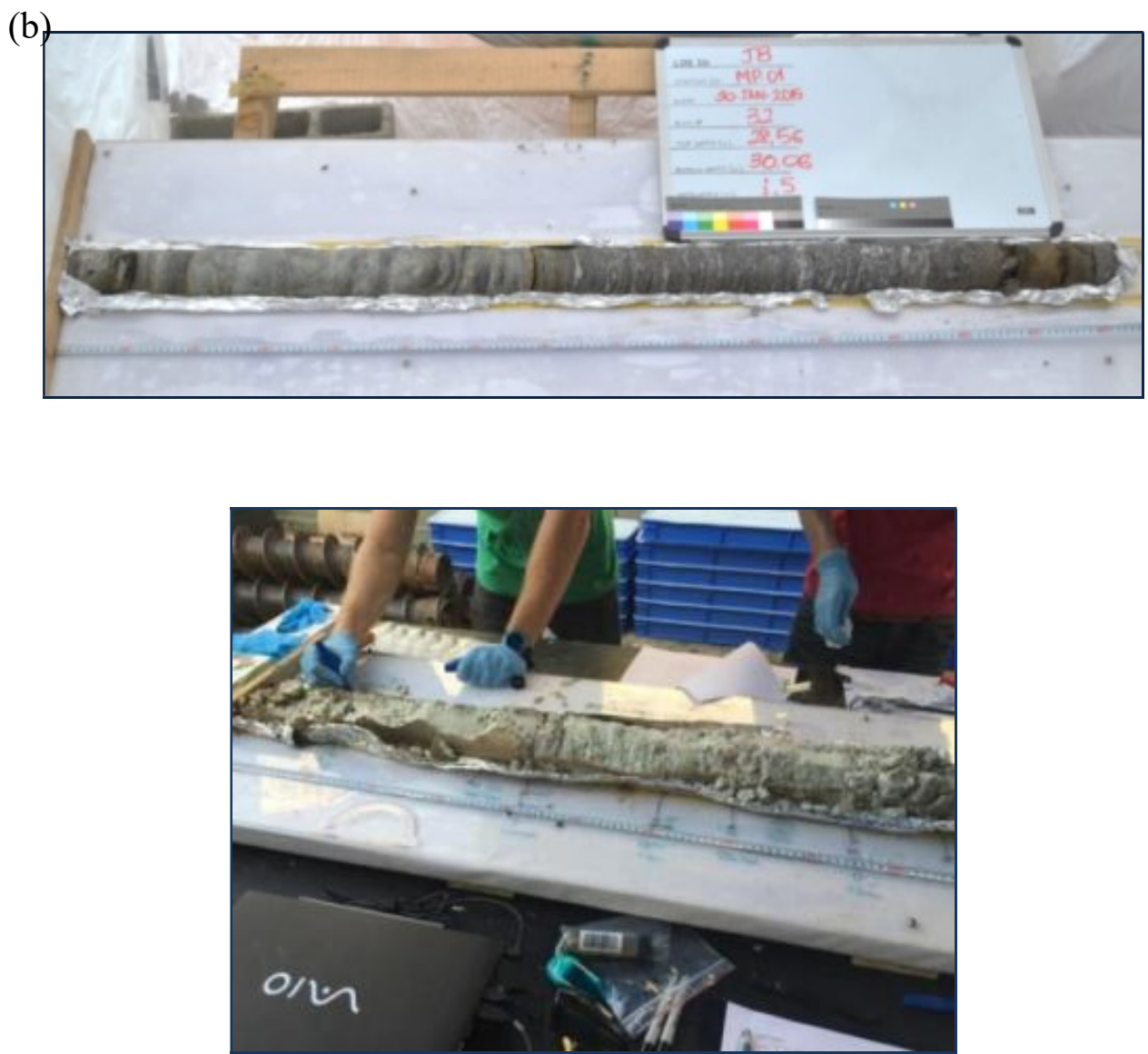

Figura 32 - Estação de descrição litológico-estrutural de testemunhos e coleta de amostras.

As amostras de solo aluvionar e de alteração foram coletadas com seringas (Figura 33a) e depositadas em vials, sendo utilizada uma nova seringa a cada ponto amostrado. No caso das amostras de rocha, era necessário quebrá-las com uma marreta (Figura 33b) e posteriormente 
encaminhá-las para o triturador da terceira estação (Figura 34), a fim de obter uma granulação próxima à fração areia, a qual era então armazenada nos vials.
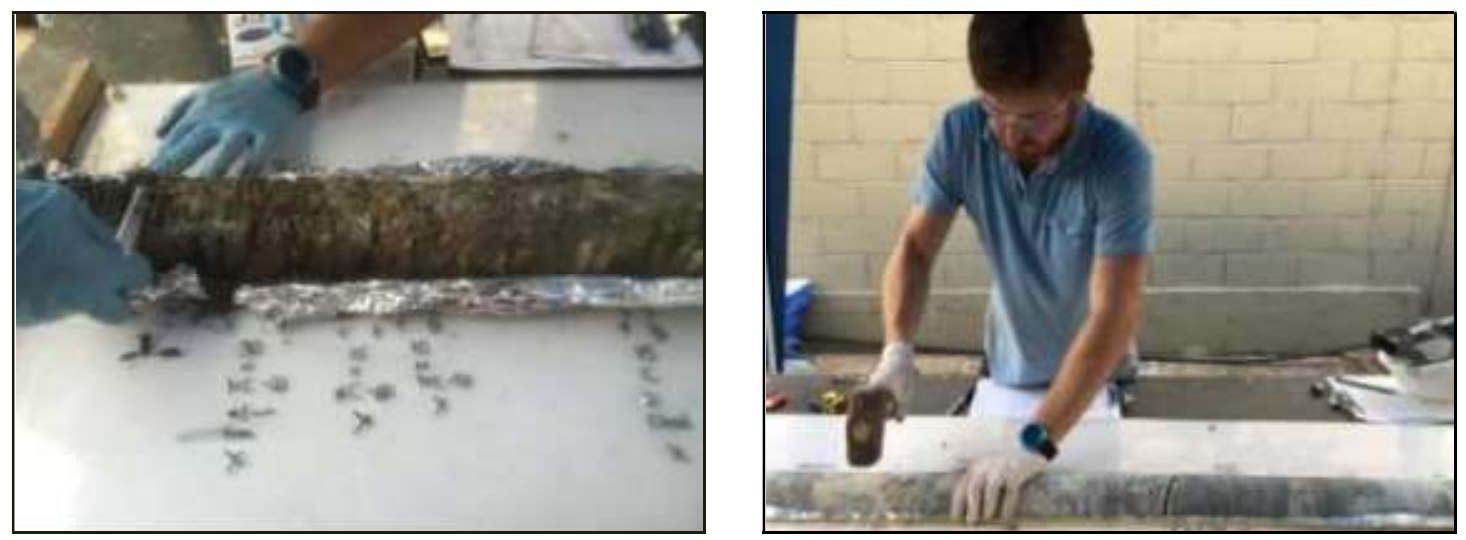

Figura 33 - (a) Coleta de amostras de solo de alteração com seringas e (b) de rocha com marreta.

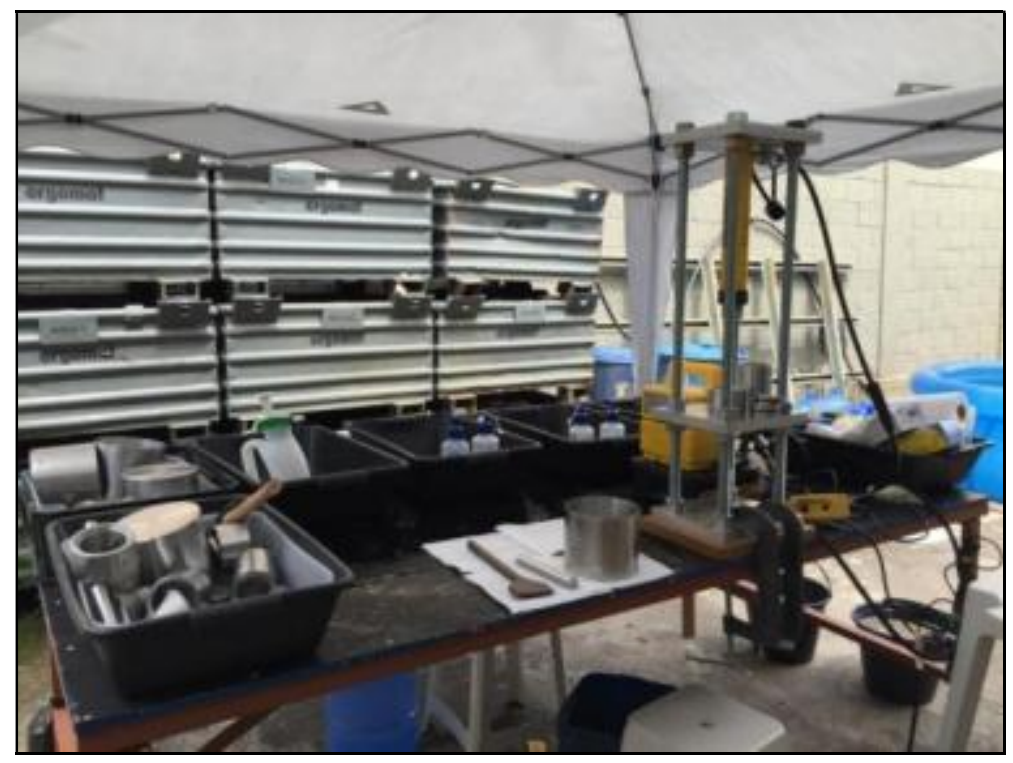

Figura 34 - Triturador (crusher) da terceira estação. À frente, na mesa, o recipiente e talhadeira para retirada das bordas das amostras e crusher com utensílios. Ao fundo, bandejas para as etapas de descontaminação das peças.

Os recipientes em que se armazenaram as amostras foram previamente pesados, vazios e com metanol, composto que se destina à preservação da amostra. Após a coleta, todas as amostras foram mantidas refrigeradas e pesadas em laboratório antes de ser encaminhada à 
Universidade de Guelph para as análises químicas de VOCs. Foram coletadas 330 amostras de solo e rocha na primeira etapa de campo e mais 92 outras na segunda campanha.

Após a coleta das amostras e da execução de todas as marcações referentes à descrição litológico-estrutural, os testemunhos eram levados novamente à estação fotográfica, para que fosse registrada sua condição final.

Ao término do registro fotográfico, os testemunhos foram armazenados em caixas plásticas e orientados ao longo do sentido de avanço das manobras de perfuração. Posteriormente, 27 amostras de rocha alterada/saprolito e rocha sã foram selecionadas para análise mineralógica por microscopia ótica. As lâminas compunham seções delgadas com espessura de $3 \mu \mathrm{m}$, sendo utilizados microscópios petrográficos da marca Olympus (modelo BX-50) e uma câmera digital também da marca Olympus (modelo E 330), para registro fotográfico das lâminas.

A descrição litológica e mineralógica dos perfis de sondagem permitiu identificar, do topo para base as seguintes unidades geológicas:

- 0,0-0,80 m - Unidade antropogênica: Aterro composto por silte argiloso, marrom.

- 0,80-2,80 m - Sedimento Aluvionar: sequência de camadas de argila orgânica, preta, interdigitadas a porções de areia fina, com matriz argilosa, cinza escura;

- 2,80 -7,40 m: Saprolito: intercalação de camadas de areia fina a média, pouco siltosa, branca a bege, por vezes bastante oxidável, com espessura métrica, intercaladas com porções de argila siltosa, rica em micas, com lentes arenosas (fina) milimétricas, de cor cinza esbranquiçado;

- 7,40 - 14,80 m: Rocha alterada mole. camadas de areia fina a média, pouco siltosa, branca a bege, com estruturas reliquiares (textura lepidogranoblástica), cristais de feldspato moderadamente alterados, quartzo, óxidos e muscovita, com espessura métrica associados à alteração de rocha gnáissica fina. Localmente, se observa frações centimétricas e métricas de areia média argilosa, com muscovita, associadas a zonas de alteração de pegmatito e a presença de um veio de quartzo, com turmalina, bem preservado (Figura 35). Intercalado a estes horizontes, com espessura métrica, se observa a presença de argila siltosa, rica em micas, com intercalações de lentes arenosas (fina) milimétricas, com foliação preservada (Figura 36) mais bem preservada do que no saprolito;

- 14,80-24,05 m: Rocha alterada dura: Esse horizonte é definido pela mudança do método de perfuração, de trados ocos helicoidais para sondagem rotativa com broca diamantada. Nota-se a intercalação centimétrica a métrica de quatro litotipos: veios de quartzo; granada- 
biotita-feldspato-quartzo-gnaisse, com bandamento incipiente, pouco alterado, com matriz mais friável do que a rocha sã; granada-biotita-feldspato-quartzo-gnaisse, bandado, pouco alterado, mais friável do que a rocha sã e granada-turmalina-feldspato-quartzo-pegmatito, pouco alterado, mais friável do que a rocha sã.

- 24,05 - 60,13 m: Rocha Sã: intercalação centimétrica a métrica de três litotipos: granadabiotita-feldspato-quartzo-gnaisse, fino e com bandamento incipiente (Figura 37); granadabiotita-feldspato-quartzo-gnaisse, bandado (Figura 38) e granada-turmalina-feldspatoquartzo-pegmatito (Figura 39).

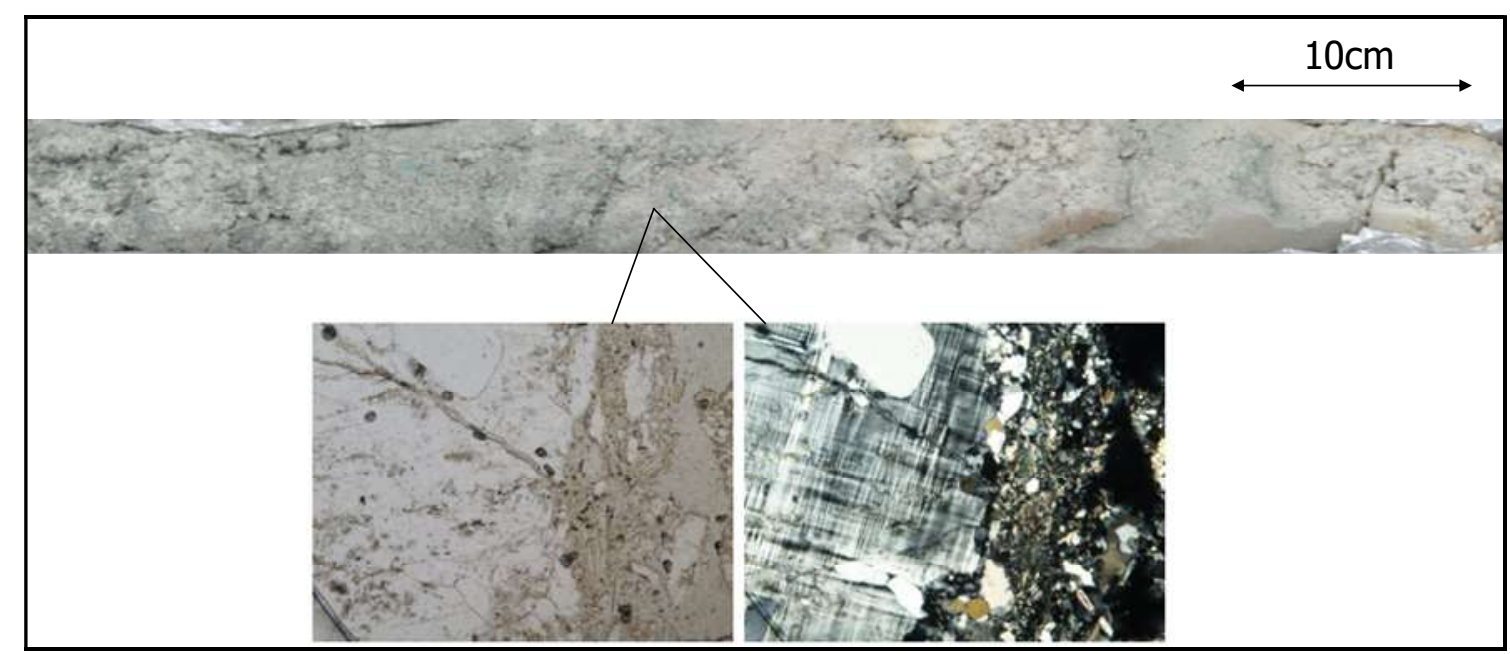

Figura 35 - Testemunho de pegmatito alterado (estrato de rocha alterada mole). Grão de turmalina em meio a grãos de quartzo e muscovita. Profundidade de $\mathbf{9 , 7 0} \mathrm{m}$. Sem escala.

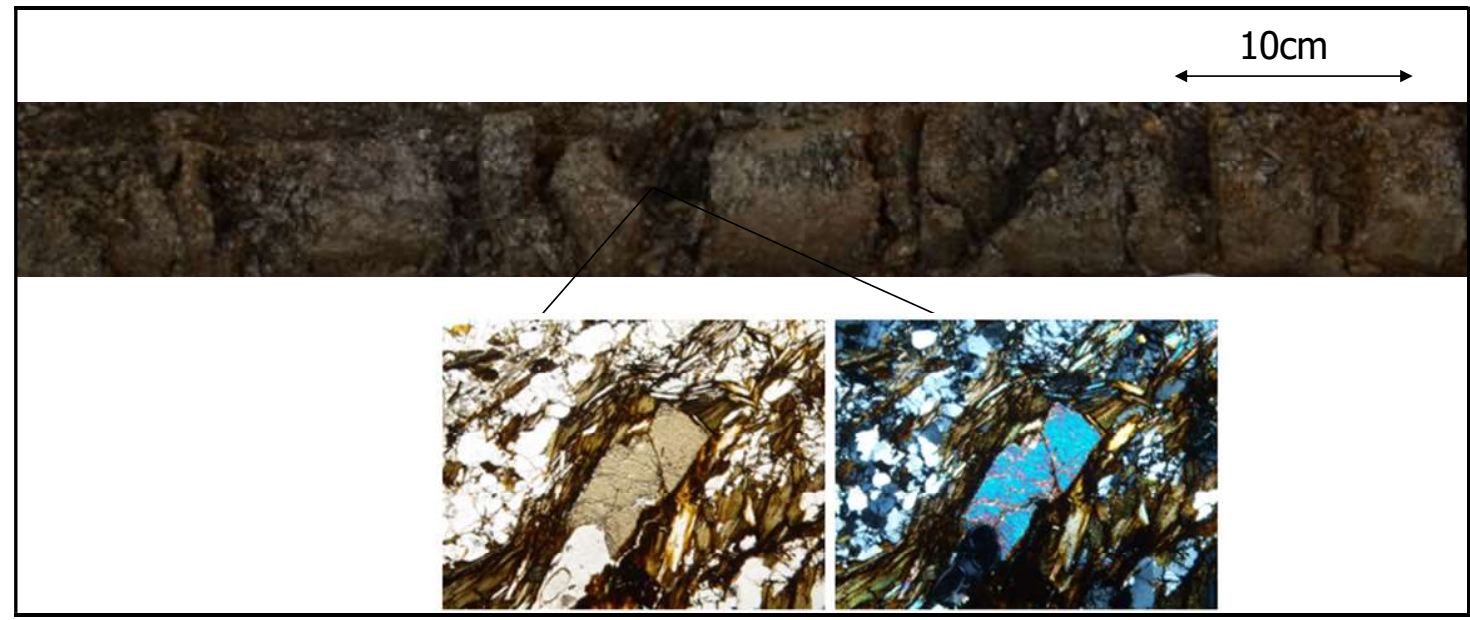

Figura 36 - Testemunho de gnaisse bandado alterado. Cristais oxidados de biotita, grãos de quartzo e cristal de turmalina ao centro. Profundidade de $12,0 \mathrm{~m}$. Sem escala. 


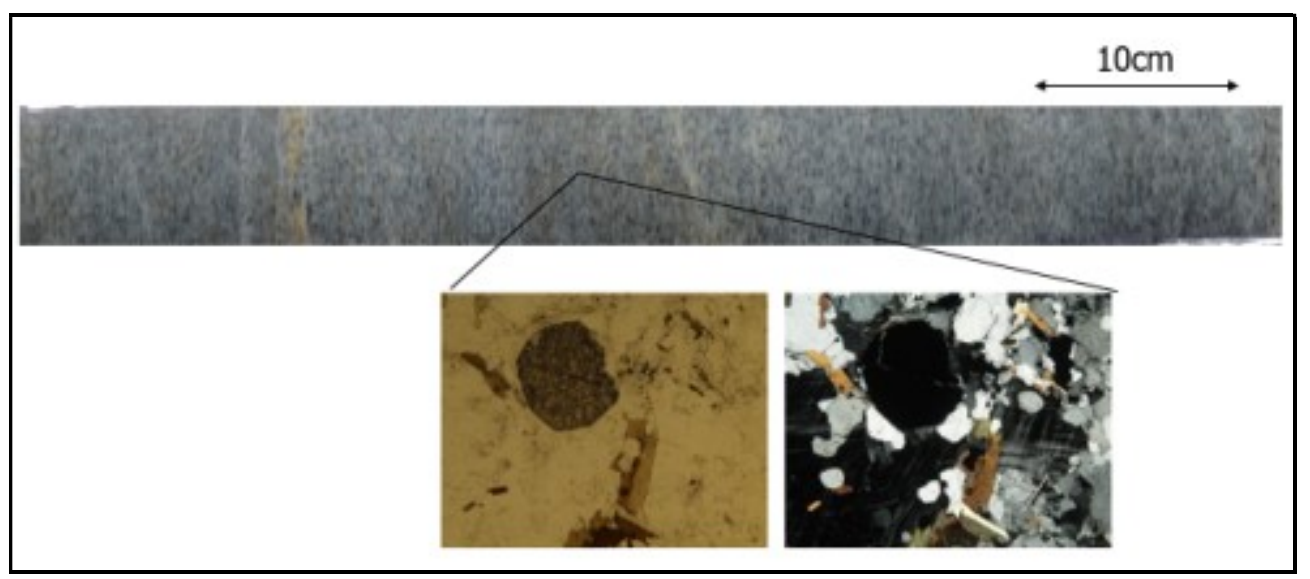

Figura 37 - Testemunho de granada-biotita-feldspato-quartzo-gnaisse fino. Grão de granada em meio a matriz com quartzo, feldspato e biotita com inclusões de zircão. Profundidade de 45,60m. Sem escala.

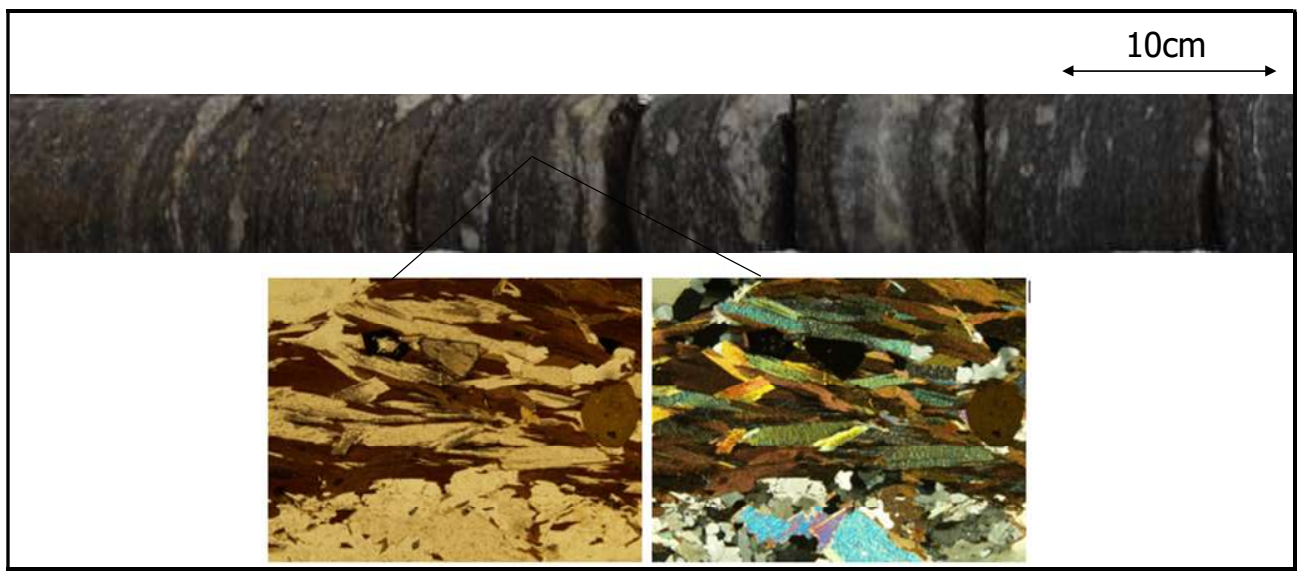

Figura 38 - Testemunho de granada-biotita-feldspato-quartzo-gnaisse, bandado. Cristais de biotita e quartzo orientados (foliação). Profundidade de $28,06 \mathrm{~m}$. Sem escala.

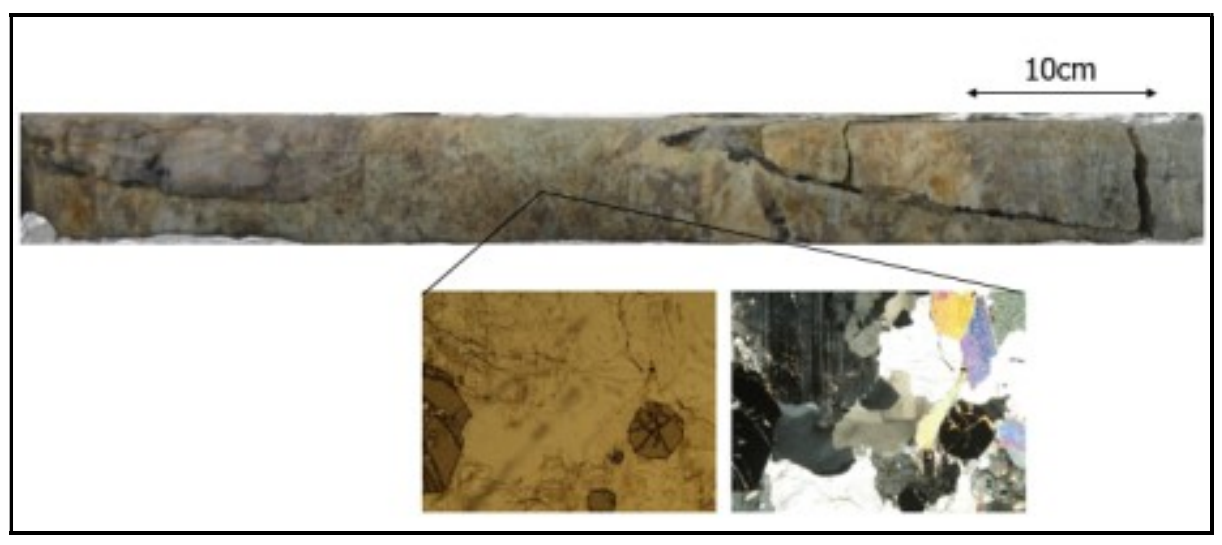

Figura 39 - Testemunho de granada -turmalina-feldspato-quartzo-pegmatito. Cristais de feldspato, quarzto, granada e muscovita. biotita e quartzo orientados (foliação). Profundidade de 39,90m. Sem escala. 
A classificação em sedimentos, saprolito, rocha alterada mole, rocha alterada dura e rocha sã segue o modelo proposto por Vaz (1996), em que os critérios de classificação do material geológico relaciona-se com a resposta do material ao método de escavação/perfuração empregado.

Os sedimentos na área de estudo são atribuídos às coberturas aluvionares da Bacia Sedimentar de São Paulo, enquanto as rochas do embasamento (e respectivos materiais de alteração) são associadas às rochas granito-gnáissicas do Complexo Embu (Riccomini et al., 1992; São Paulo SMA SSE, 1999).

\subsubsection{Perfilagens geofísicas}

As perfilagens geofísicas de calibre, gama natural, imageamentos óptico (OPTV) e acústico (ATV) foram executadas na perfuração MP-01. Os resultados das sondas de calibre, OPTV e ATV permitiram confirmar zonas de fraturas constatadas durante a sondagem e descrição de testemunhos, além de fornecerem informações adicionais quanto à espessura de tais zonas, à abertura aparente de outras fraturas observadas e à orientação de tais estruturas. Tais dados foram fundamentais para a avaliação do padrão rúptil da rocha cristalina que constitui o aquífero em estudo e, em conjunto com os dados provenientes da perfilagem de temperatura, forneceram subsídios para a definição dos intervalos de interesse para realização de ensaios hidráulicos em furo aberto e, posteriormente, a determinação do sistema multinível instalado.
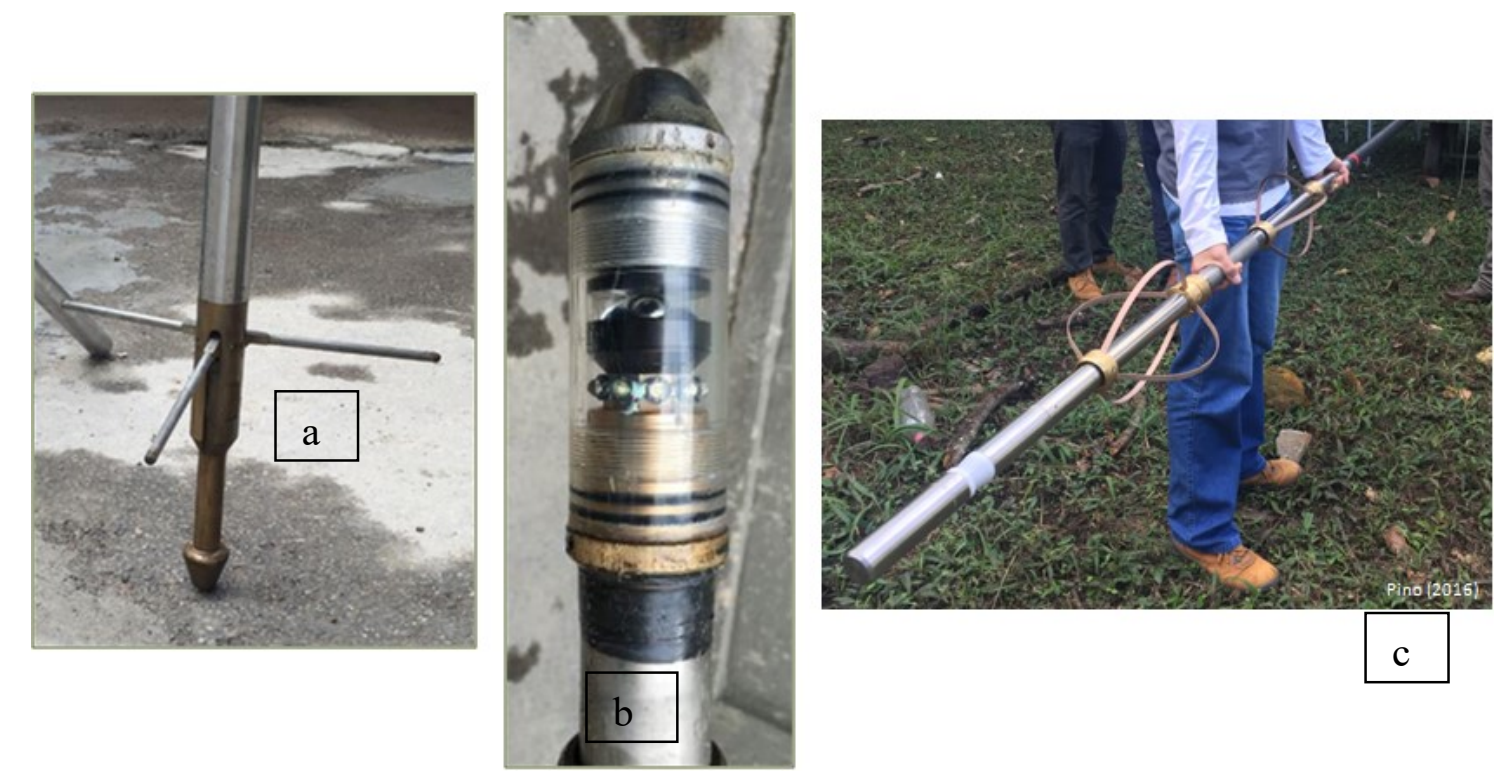

Figura 40 - Sondas de perfilagem geofísicas utilizadas: (a) cáliper; (b) imageador ótico (OTV); (c) imageador acústico (ATV) 
A Figura 41 apresenta os dados de saída das perfilagens de calibre, gama natural, imageamentos acústico e óptico, além de uma coluna com as fraturas identificadas nos últimos dois perfis. As imagens estão corrigidas para a declinação magnética de São Paulo $\left(20^{\circ} \mathrm{W}\right)$. Destacam-se aquelas oxidadas e com aberturas de ordem centimétrica abaixo de $38 \mathrm{~m}$ de profundidade, as quais são fortes indicadores da ocorrência de fluxo de água subterrânea. A Figura 42 apresenta o estereograma com a projeção dos polos das 59 fraturas identificadas através das perfilagens OPTV e ATV.

A análise preliminar dos dados de perfilagem geofísica corroboram as observações de estruturas realizadas durante a descrição do testemunho de sondagem. Estruturas de baixo ângulo (0-30 $0^{\circ}$ de mergulho) ocorrem com maior frequência nas rochas mais xistosas, paralelas à foliação, enquanto aquelas de médio ângulo $\left(30-60^{\circ}\right)$ são mais comuns nas rochas gnáissicas. Ademais, as perfilagens permitiram confirmar a ocorrência das quatro zonas de fraturamento mais expressivas identificadas durante a perfuração, caracterizando intervalos de interesse. 


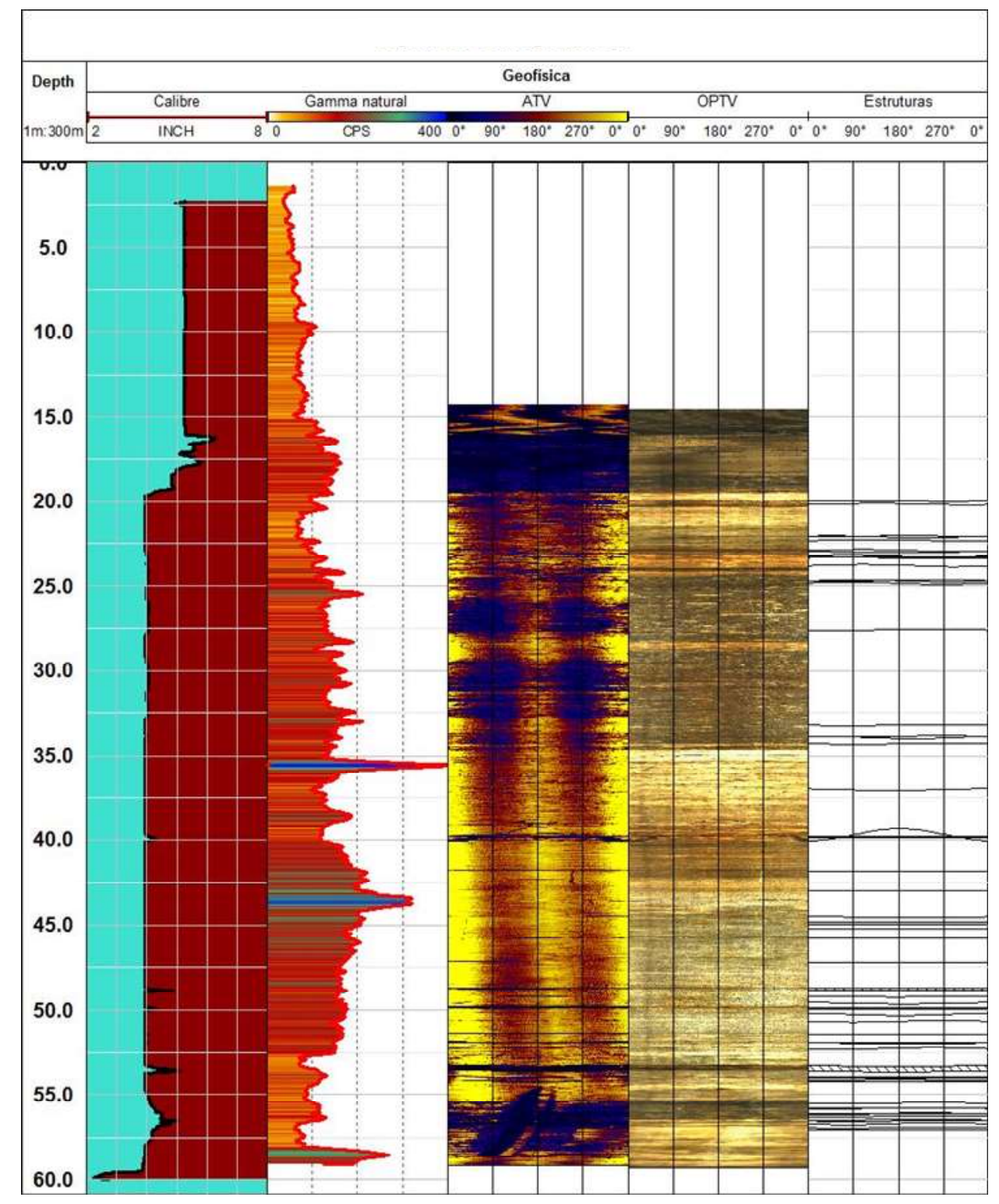

Figura 41 - Resultados das perfilagens ótica, acústica, gama e calibre realizadas na sondagem MP-01, seguidas das respectivas interpretações de ocorrência de fraturas.

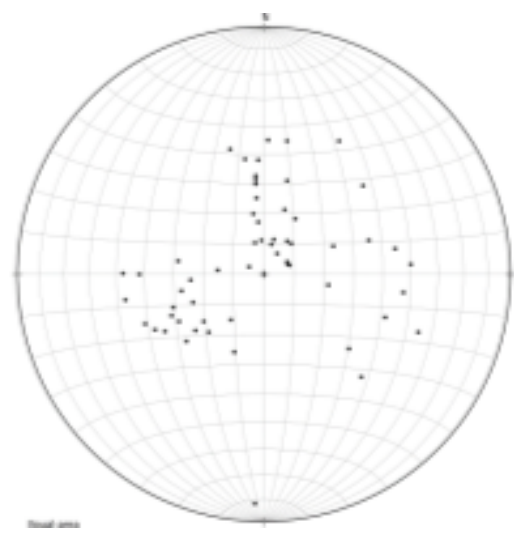

Figura 42 - Projeção dos polos das fraturas identificadas da sondagem MP-01 através das perfilagens de ATV e OPTV (n=59). Projeção de área igual, hemisfério inferior. 


\subsubsection{Instalação do FLUTe blank liner}

A lona impermeável FLUTe blank liner foi instalada no furo de sondagem MP-01 que se encontrava aberto. O FLUTe liner, quando instalado, impede que a perfuração funcione como um duto que transporta a água de uma fratura para outra, inibindo a circulação natural da água dentro do furo e, portanto, bloqueando o espalhamento de contaminantes dissolvidos nas diferentes fraturas do aquífero, se existentes. O liner é constituído de um tubo flexível de nylon revestido de uretano, o qual é inflado no furo pela adição de água no seu interior (Figura 19). A lenta descida do FLUTe liner para dentro do furo faz com que a água subterrânea da perfuração seja gradualmente expulsa através das fraturas que interceptam o furo. As Figura 43 ilustra a instalação do liner e o poço já com o sistema instalado.
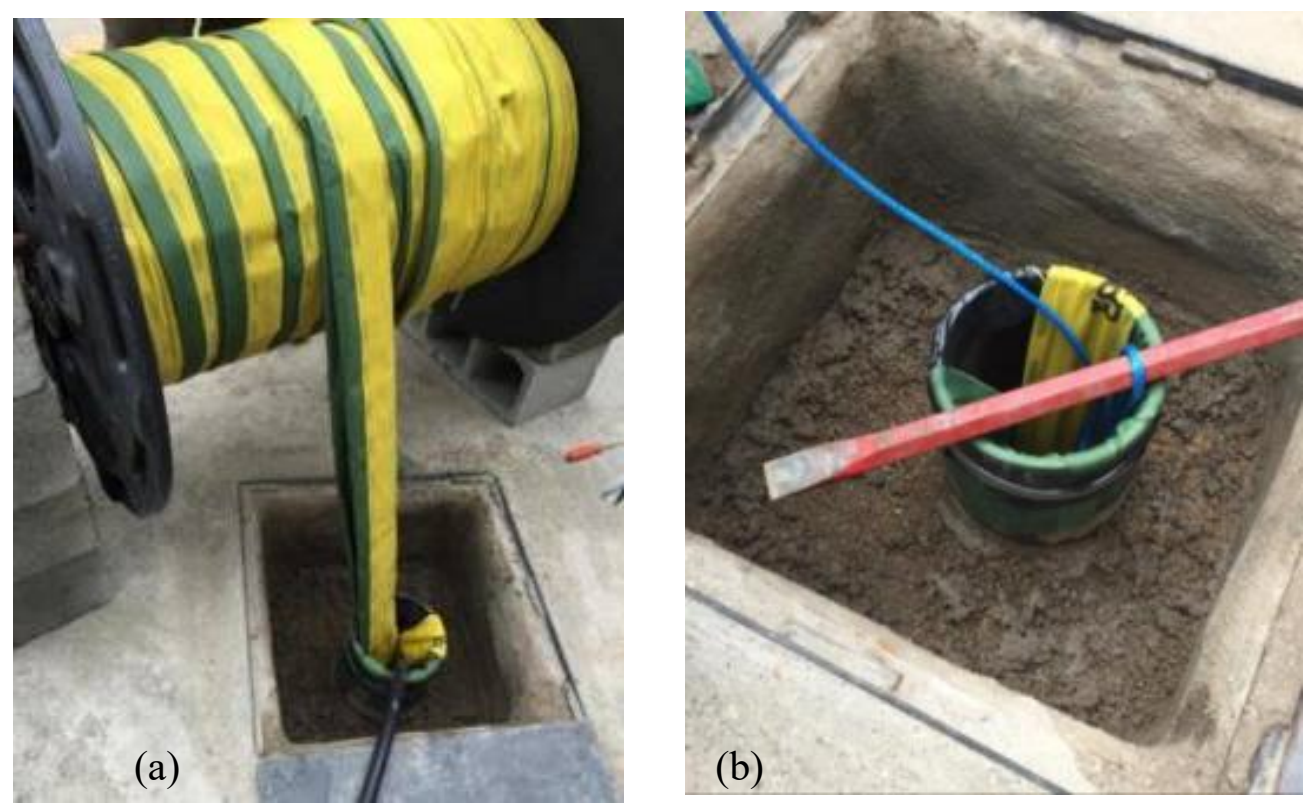

Figura 43 - (a) Instalação do FLUTe blank liner. Sua descida é possibilitada pela pressão exercida pela água inserida por dentro do liner (mangueira preta) e pela consequente saída de água do furo pelas fraturas que o interceptam. (b) FLUTe liner instalado, preso no topo do revestimento com abraçadeira.

O FLUTe liner permite sua instalação e remoção tantas vezes sejam necessárias, possibilitando a execução de diferentes ensaios ao longo do furo aberto e o seu posterior selamento temporário. Conforme descrito por Keller (2004), este procedimento visa a eliminação da via de contaminação cruzada induzida pelo fluxo natural vertical de água subterrânea (Sterling et al., 2005), que ocorre devido à diferença do potencial hidráulico existente nas diferentes fraturas que interceptam um novo furo de sondagem. 


\subsubsection{Perfilagem de temperatura}

A perfilagem de temperatura foi realizada na sondagem MP-01 com furo selado pelo FLUTe liner, aplicando-se o método Active Line Source (ALS - Pehme et al., 2013). Este método permite identificar as fraturas hidraulicamente ativas para o fluxo de água. Primeiro, foi executada a perfilagem com o furo na temperatura ambiente, cuja curva resultante recebe a denominação P (perfil passivo). Em seguida, de acordo com o método estabelecido por Pehme et al. (2010, 2013), a coluna estática de água no interior do furo selado é aquecida continuamente em toda a extensão do furo, durante um período de 4 a 6 horas, criando rapidamente um forte desequilíbrio termal nas proximidades do furo. Nas 24 horas que seguem o aquecimento, perfis de temperatura são medidos conforme o calor da coluna de água se dissipa, com uma precisão de $0,001^{\circ} \mathrm{C}$. Tais perfis recebem a denominação $\mathrm{C} 1, \mathrm{C} 2, \ldots, \mathrm{Cn}$ (perfis de resfriamento - cooling). A ocorrência de picos negativos (“aberrações") nos perfis é usada para identificar fraturas com fluxo de água subterrânea, corroborando com a definição de intervalos de interesse para a realização de intervalos hidráulicos. A Figura 44 apresenta os dados brutos da perfilagem de temperatura ALS, que ora encontram-se em processo de interpretação.

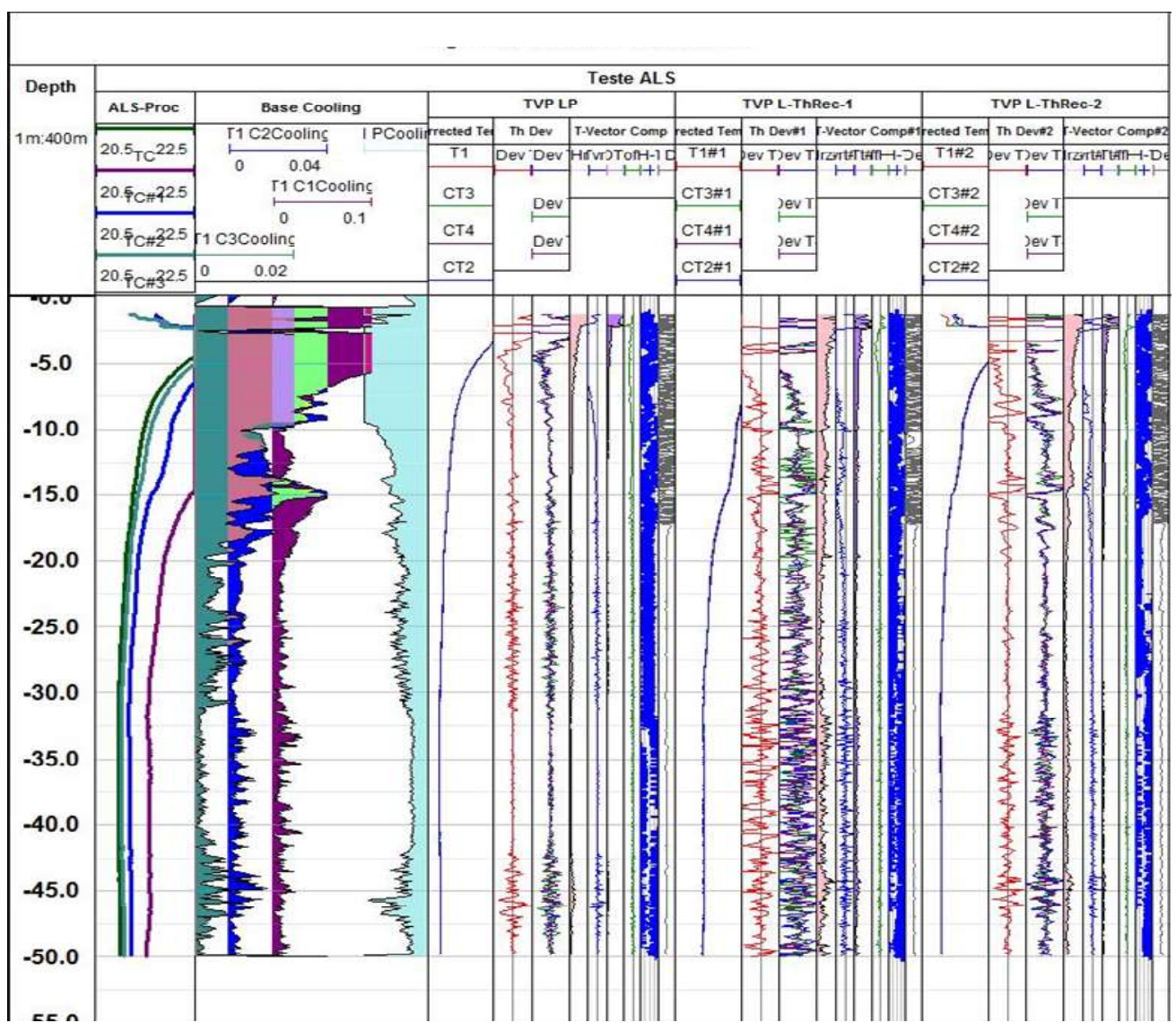

Figura 44 - Dados brutos do perfil ALS 


\subsubsection{Análises químicas de solo e rocha}

As análises químicas das amostras de solo e rocha coletadas na primeira etapa de perfuração (MP-01), que somaram 330 unidades, foram realizadas na Escola de Engenharia da Universidade de Guelph, Canadá. Posteriormente à segunda etapa de campo, outras 92 amostras de solo e rocha da sondagem MP-01A foram analisadas no mesmo laboratório.

A metodologia analítica, baseada no método de extração shake and flask, é baseada nos trabalhos de Hurley (2003) e Kennel (2007). Os resultados foram reportados em $\mu \mathrm{g}$ do composto por grama de rocha, a partir da seguinte relação:

$$
\mathrm{C}_{\text {rocha }}=\left(\mathrm{C}_{\text {metanol }} * \mathrm{~V}_{\text {metanol }}\right) / \mathrm{M}_{\text {rocha }} \quad \text { Equação } 6
$$

onde:

$\mathrm{C}_{\text {rocha: }}$ Concentração na rocha $(\mu \mathrm{g} / \mathrm{g})$;

$\mathrm{C}_{\text {metanol: }}$ Concentração no metanol ( $\mu \mathrm{g}$ do Composto / $\mathrm{L}$ de metanol);

$\mathrm{V}_{\text {metanol: }}$ Volume de metanol no vial (L); e

$\mathrm{M}_{\text {rocha: }}$ : Massa (g) de rocha presente no vial.

Dentre os compostos analisados, destacam-se os seguintes: Tetracloroeteno (PCE), Tricloroeteno (TCE), cis-1,2-Dicloroeteno (cis-1,2-DCE), 1,1-Dicloroeteno (1,1-DCE) e trans1,2-Dicloreteno (trans-1,2-DCE), caracterizados como compostos de interesse nessa pesquisa. $\mathrm{O}$ composto Cloreto de Vinila (CV), apesar de também ser considerado de interesse nessa pesquisa, não pode ser analisado devido limitações analíticas.

Os resultados analíticos foram plotados no programa Wellcad, em função da profundidade, juntamente com os dados geológicos e de profundidade de fraturas. A Figura 45 apresenta os resultados analíticos obtidos, onde se observa a predominância de concentrações dos produtos de degradação do PCE nos primeiros três metros de profundidade, indicativos de processo de biodegradação deste composto.

Em profundidade, a partir de aproximadamente $5 \mathrm{~m}$, nota-se uma grande variação das concentrações de PCE e TCE, de maneira estratificada, havendo picos de concentração centimetricamente intercalados a baixos valores de concentração. Os maiores picos de concentração de PCE e TCE são observados entre 8,0 e 9,27 m e de 13,83 a 14,04 m, normalmente correspondentes à presença de gnaisse bandado alterado (rocha alterada mole). Este horizonte geológico é bastante heterogêneo e contém variações centimétricas mais arenosas, relacionadas a bandas quartzosas e de fração silto-arenosa, associadas a porções máficas, ricas 
em biotita. Adicionalmente, se observa sistemas de fraturas paralelas à foliação ainda preservada, evidenciadas pela presença de oxidação.

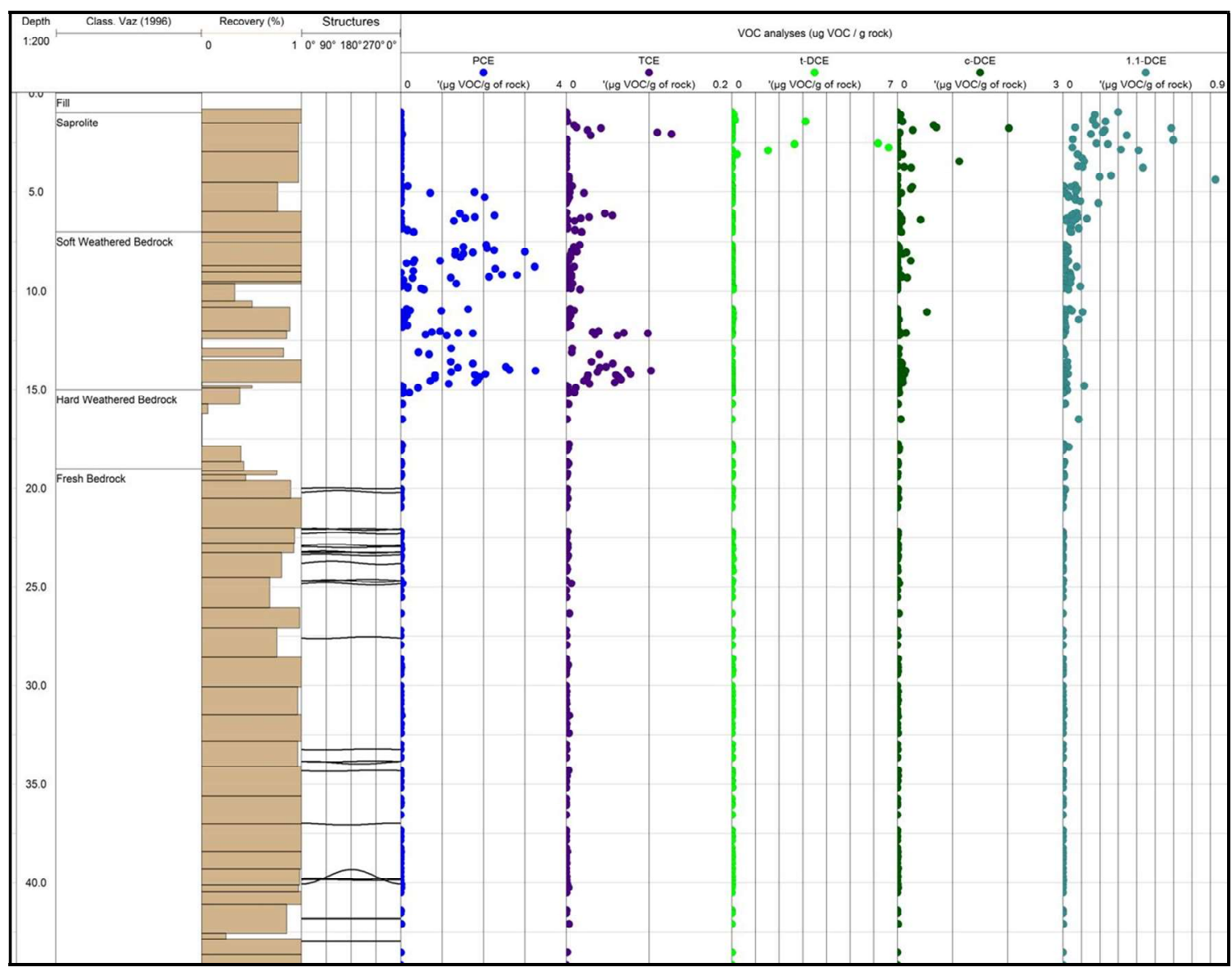

Figura 45 - Resultados das Análises Químicas de solo e rocha (MP-01).

Conforme observado na Figura 45, há um forte declínio de concentração dos compostos em aproximadamente $15 \mathrm{~m}$ de profundidade, concordante com o contato entre os horizontes de rocha alterada mole e dura. Entretanto, o campo amostral neste horizonte foi baixo devido à baixa recuperação das manobras de perfuração na primeira etapa de campo. No intuito de se avaliar mais detalhadamente este horizonte de transição, uma nova perfuração foi realizada (furo de sondagem MP-01A), sendo coletadas diversas amostras ao longo do perfil. Os resultados analíticos da segunda campanha são apresentados na Figura 46. 


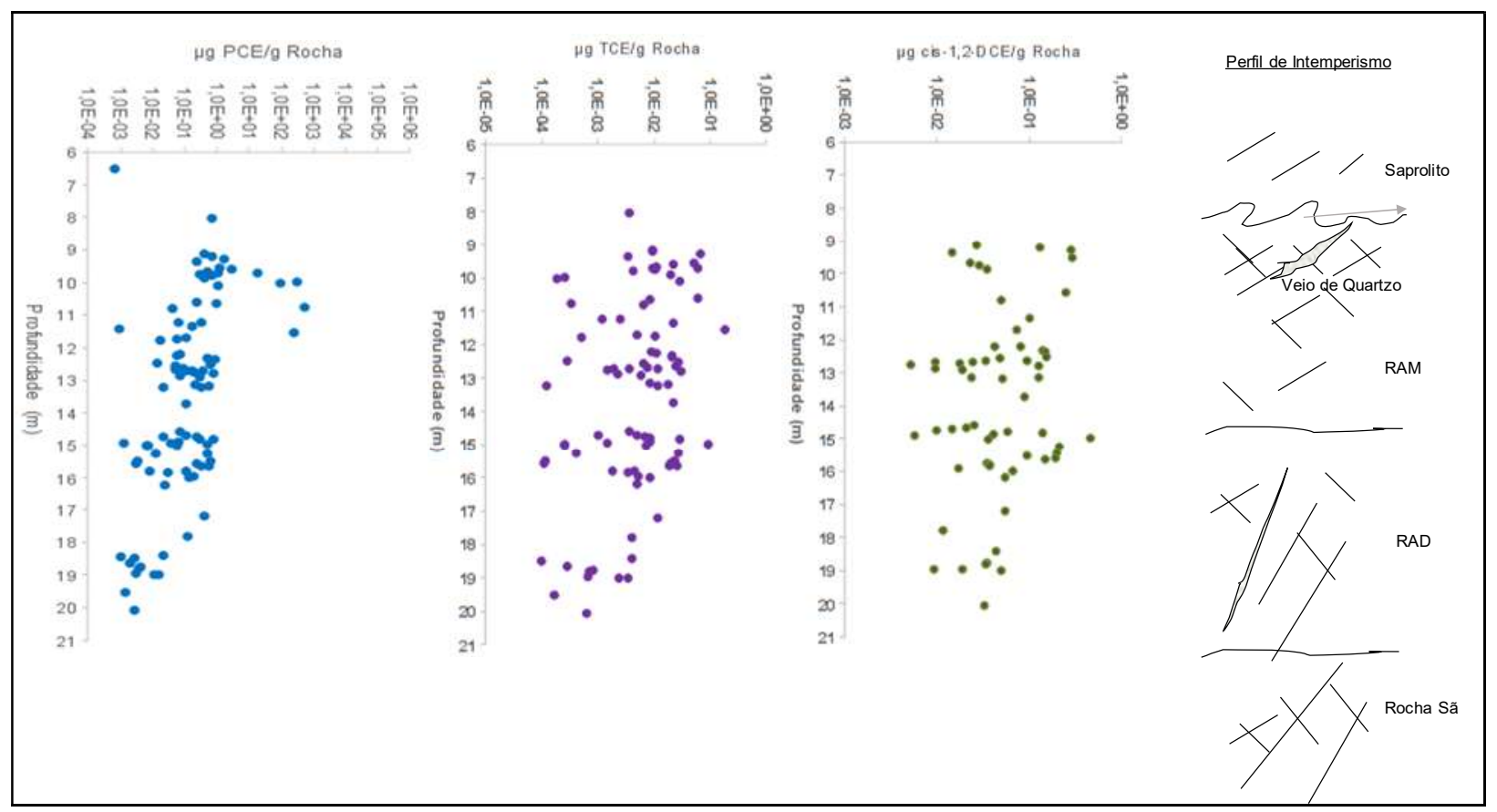

Figura 46 - Resultados das Análises Químicas de solo e rocha - 2a Campanha (MP-01A).

Neste novo furo MP-01A, notou-se um aumento expressivo da ordem de grandeza das concentrações de PCE, chegando à máxima concentração de $531 \mu \mathrm{g} / \mathrm{g}$. Tal concentração é indicativa do potencial da presença de fase residual de PCE e reflete uma forte heterogeneidade local em relação à distribuição horizontal das concentrações dos compostos organoclorados. Em profundidade, se observa uma diminuição das concentrações. Em relação ao horizonte de transição RAM e RAD (entre 14,5 m e 16,0 m), se observa pouca variação nas concentrações, sugerindo a presença de massa de contaminantes ainda presente nos primeiros metros do trecho de RAD. Com o aumento da profundidade e da diminuição do grau de intemperismo, se observa um decréscimo gradacional das concentrações existentes.

\subsubsection{Propriedades físicas das amostras de rocha}

No intuito de se avaliar a variação vertical das propriedades físicas das diferentes litologias e dos horizontes de intemperismo, foram coletadas 23 amostras semi-deformadas de rocha para análise laboratorial dos seguintes parâmetros físicos: porosidade total, densidade do solo e densidade de grãos, teor de umidade e fração de carbono orgânico e 10 análises granulométricas. Estas amostras foram encaminhadas ao Laboratório de Resíduos e Áreas Contaminadas (LRAC), do Instituto de Pesquisas Tecnológicas (IPT). Estes resultados permitem a executar os cálculos de massa e cálculos teóricos da concentração (pore water), tendo como referência o trabalho de Feenstra et al. (1991). A Figura 47 sumariza a relação das concentrações de PCE na rocha 
alterada e a porosidade total obtida (Lojkasek-Lima, 2016). A porosidade total observada em amostras na rocha alterada dura $(14,5 \mathrm{~m})$, que comumente não é investigada por restrições do método usual de perfuração por trado oco, indicam que este meio promove uma expressiva estocagem de massa de contaminantes.

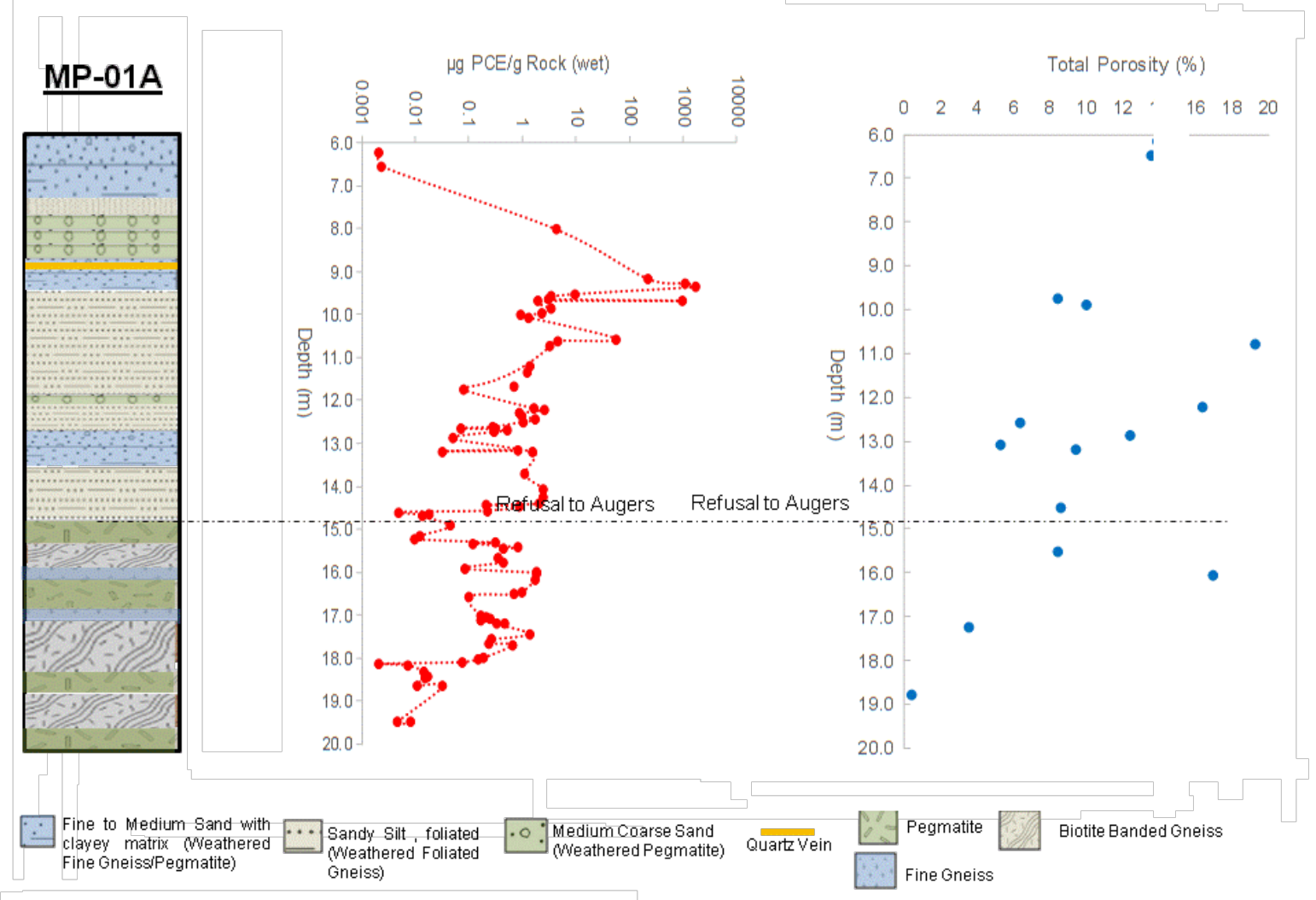

Figura 47 - Valores de porosidade total em relação a concentrações de PCE na sondagem MP-01A (Lojkasek-Lima, 2016)

\subsubsection{Ensaios hidráulicos com obturadores}

Um laboratório móvel de campo de ensaios hidráulicos, desenvolvido no contexto da tese de doutorado de Barbosa (2017), foi montado em um trailer contendo obturadores, guinchos, tripé, transdutores, datalogger, notebook, bombas de vácuo, pressão e submersa, medidores de vazão e conjuntos de cabos e tubos. O conjunto permite a realização de investigações e ensaios hidráulicos em poços de até $300 \mathrm{~m}$ de profundidade em aquíferos fraturados (Figura 48). O laboratório possibilita realizar algumas configurações de montagem e operação para que seja possível realizar até oito tipos de ensaios hidráulicos: slug/bail, carga constante, traçador, diluição, injeção, bombeamento/recuperação, bombeamento com poço de observação multinível e bombeamento com fluxo-dipolo. Também é possível a realização de amostragens de água subterrânea por três métodos: bombeamento, baixa vazão e passiva. Neste trabalho, foram 
realizados ensaios do tipo slug/bail, carga constante e bombeamento/recuperação em intervalos de interesse da perfuração MP-01, definidos com base nos resultados das perfilagens geofísicas e descrição de testemunhos de sondagem. A sequência dos ensaios realizados na sondagem MP-01 é apresentada na Figura 49.

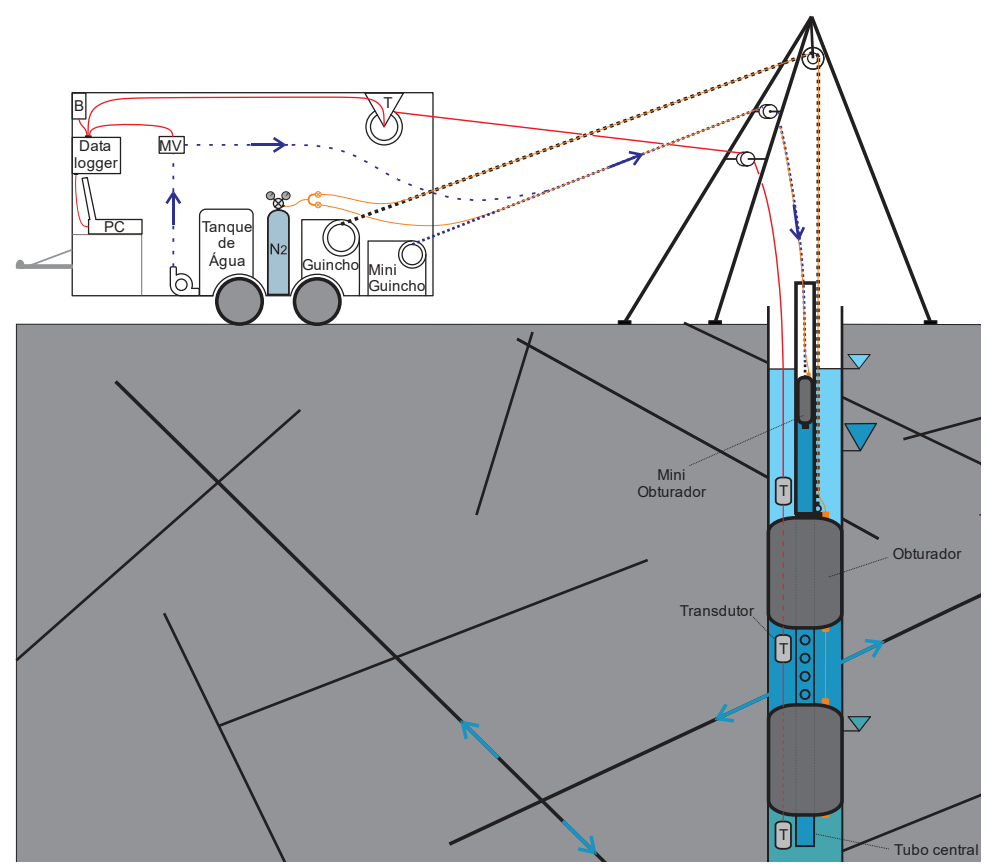
Figura 48 - Esquema de equipamentos do laboratório móvel de campo para ensaios hidráulicos com obturadores (Barbosa, 2017).

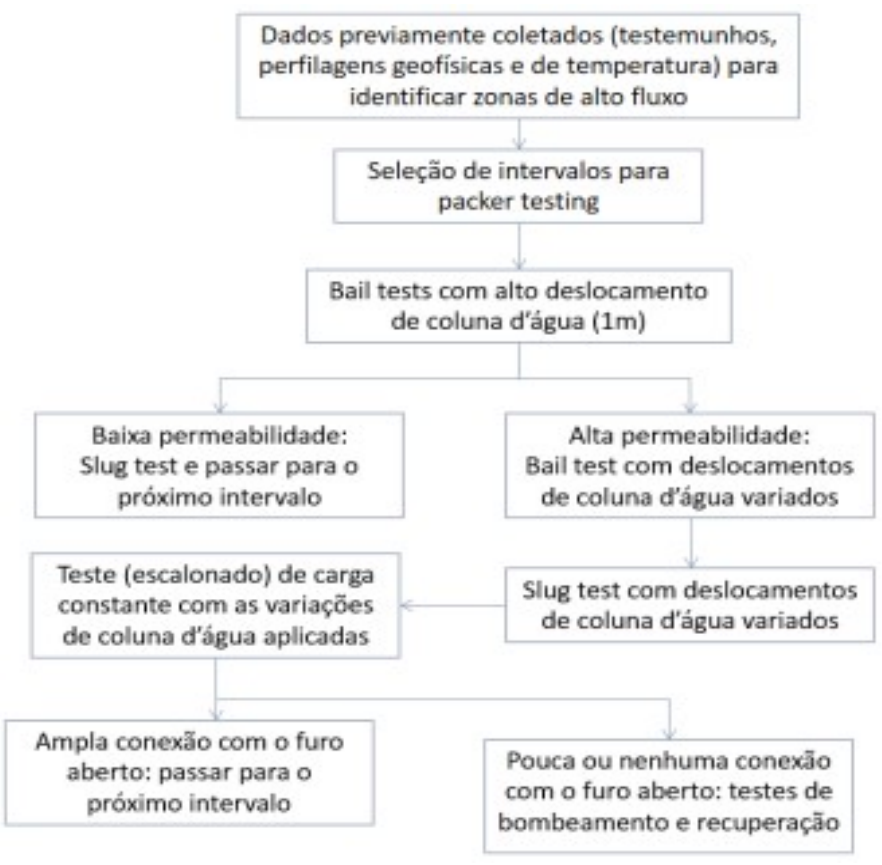

Figura 49 - Sequência dos ensaios nos testes com obturadores. 
A Figura 50 apresenta um exemplo dos ensaios tipo Bail, realizados no trecho de 23,9 a $25,5 \mathrm{~m}$. As curvas indicam a pressão em psi registrada pelos transdutores no intervalo ensaiado (Intermediário), acima (Superior) e abaixo (Inferior) dele.

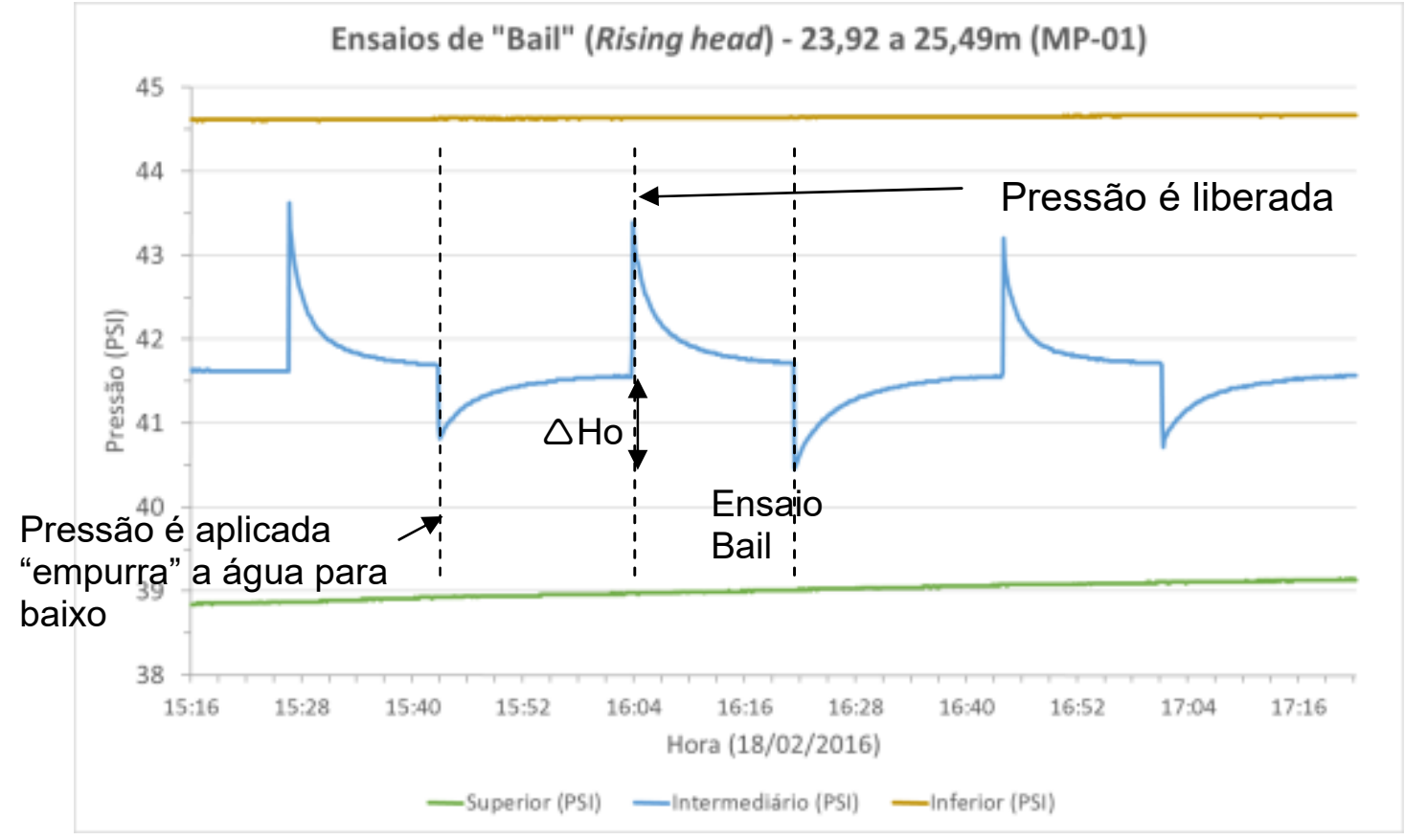

Figura 50 -Ensaios de Bail no intervalo 23,92 a 25,49 m (Barbosa, 2017)

Os intervalos ensaiados e os testes realizados com obturadores em cada trecho são resumidos na Tabela 3. Dos 17 intervalos ensaiados, foi possível calcular valores de transmissividade hidráulica para seis deles (Figura 51), através das equações apresentadas na Figura 18. Em quatro trechos, foi observado um possível curto-circuito com a formação, isto é, uma possível conexão hidráulica do trecho ensaiado com o restante do furo através de fraturas subverticais conectando as fraturas sub-horizontais que interceptam o furo. Nos sete intervalos restantes, a resposta hidráulica foi insignificante, de modo que a transmissividade nesses trechos era praticamente nula.

Nos trechos em que os testes de slug indicaram transmisividades muito baixas, observado através de longos intervalos de tempo de recuperação, outros testes não foram conduzidos porque não acrescentariam nenhuma informação a essas zonas de transmissividade desprezível. 
Tabela 3 - Ensaios realizados com obturadores em cada intervalo (Pino, 2017).

\begin{tabular}{|c|c|c|c|c|c|c|c|}
\hline $\begin{array}{l}\text { Intervalo entre } \\
\text { obturadores (m) }\end{array}$ & $\begin{array}{l}\text { Topo do } \\
\text { intervalo (m) }\end{array}$ & \begin{tabular}{|l} 
Base do \\
intervalo (m)
\end{tabular} & $\begin{array}{l}\mathrm{N}^{0} \text { de fraturas } \\
\text { no intervalo }\end{array}$ & R.H ${ }^{2}$. & F.H. ${ }^{3}$ & C.H. ${ }^{4}$ & I. $^{5}$ \\
\hline 1,83 & 16.06 & 17.87 & 0 & $\checkmark$ & $\checkmark$ & - & - \\
\hline 1,83 & 17.85 & 19.66 & 0 & $\checkmark$ & $\checkmark$ & $\checkmark$ & - \\
\hline 1,83 & 18.88 & 20.69 & 1 & $\checkmark$ & $\checkmark$ & - & - \\
\hline 1,83 & 20.69 & 22.5 & 3 & $\checkmark$ & - & - & - \\
\hline 1,57 & 23.92 & 25.49 & 3 & $\checkmark$ & $\checkmark$ & $\checkmark$ & - \\
\hline 1,57 & 25.59 & 27.16 & 0 & $\checkmark$ & $\checkmark$ & - & - \\
\hline 1,57 & 27.16 & 28.73 & 1 & $\checkmark$ & $\checkmark$ & - & - \\
\hline 1,57 & 28.73 & 30.3 & 0 & $\checkmark$ & $\checkmark$ & - & - \\
\hline 1,57 & 30.3 & 31.87 & 0 & $\checkmark$ & $\checkmark$ & - & - \\
\hline 1,57 & 31.87 & 33.44 & 1 & $\checkmark$ & $\checkmark$ & - & - \\
\hline 1,57 & 33.44 & 35.01 & 3 & $\checkmark$ & $\checkmark$ & - & - \\
\hline 1,57 & 35.01 & 36.58 & 0 & $\checkmark$ & $\checkmark$ & - & - \\
\hline 1,57 & 36.58 & 38.15 & 1 & $\checkmark$ & $\checkmark$ & - & - \\
\hline 1,57 & 38.5 & 40.07 & 3 & $\checkmark$ & $\checkmark$ & $\checkmark$ & - \\
\hline 1,57 & 40.07 & 41.64 & 2 & $\checkmark$ & $\checkmark$ & $\checkmark$ & - \\
\hline 1,57 & 42.5 & 44.07 & 1 & $\checkmark$ & $\checkmark$ & - & - \\
\hline 1,57 & 44.4 & 45.97 & 5 & $\checkmark$ & $\checkmark$ & $\checkmark$ & - \\
\hline 1,57 & 46.4 & 47.97 & 1 & $\checkmark$ & $\checkmark$ & $\checkmark$ & - \\
\hline 1,57 & 47.8 & 49.37 & 2 & $\checkmark$ & $\checkmark$ & - & - \\
\hline 1,57 & 48.6 & 50.17 & 4 & $\checkmark$ & - & - & - \\
\hline 1,57 & 49.3 & 50.87 & 4 & $\checkmark$ & $\checkmark$ & - & - \\
\hline 1,57 & 50.83 & 52.4 & 4 & $\checkmark$ & - & - & - \\
\hline 1,57 & 52.7 & 54.27 & 6 & $\checkmark$ & $\checkmark$ & - & - \\
\hline 1,57 & 54.34 & 55.91 & 3 & $\checkmark$ & $\checkmark$ & $\checkmark$ & - \\
\hline 1,57 & 55.95 & 57.52 & 8 & $\checkmark$ & $\checkmark$ & $\checkmark$ & $\checkmark$ \\
\hline 1,57 & 53.75 & 55.32 & 5 & $\checkmark$ & $\checkmark$ & - & - \\
\hline 1,57 & 22.4 & 23.97 & 6 & $\checkmark$ & $\checkmark$ & $\checkmark$ & - \\
\hline
\end{tabular}

${ }^{1}$ Fraturas identificadas em análise preliminar das perfilagens geofísicas.

${ }^{2}$ Rising head test: teste de slug.

${ }^{3}$ Falling head test: teste de bail.

${ }^{4}$ Constant head test: teste escalonado de carga constante.

${ }^{5}$ Injection test: teste de injeção de água. 


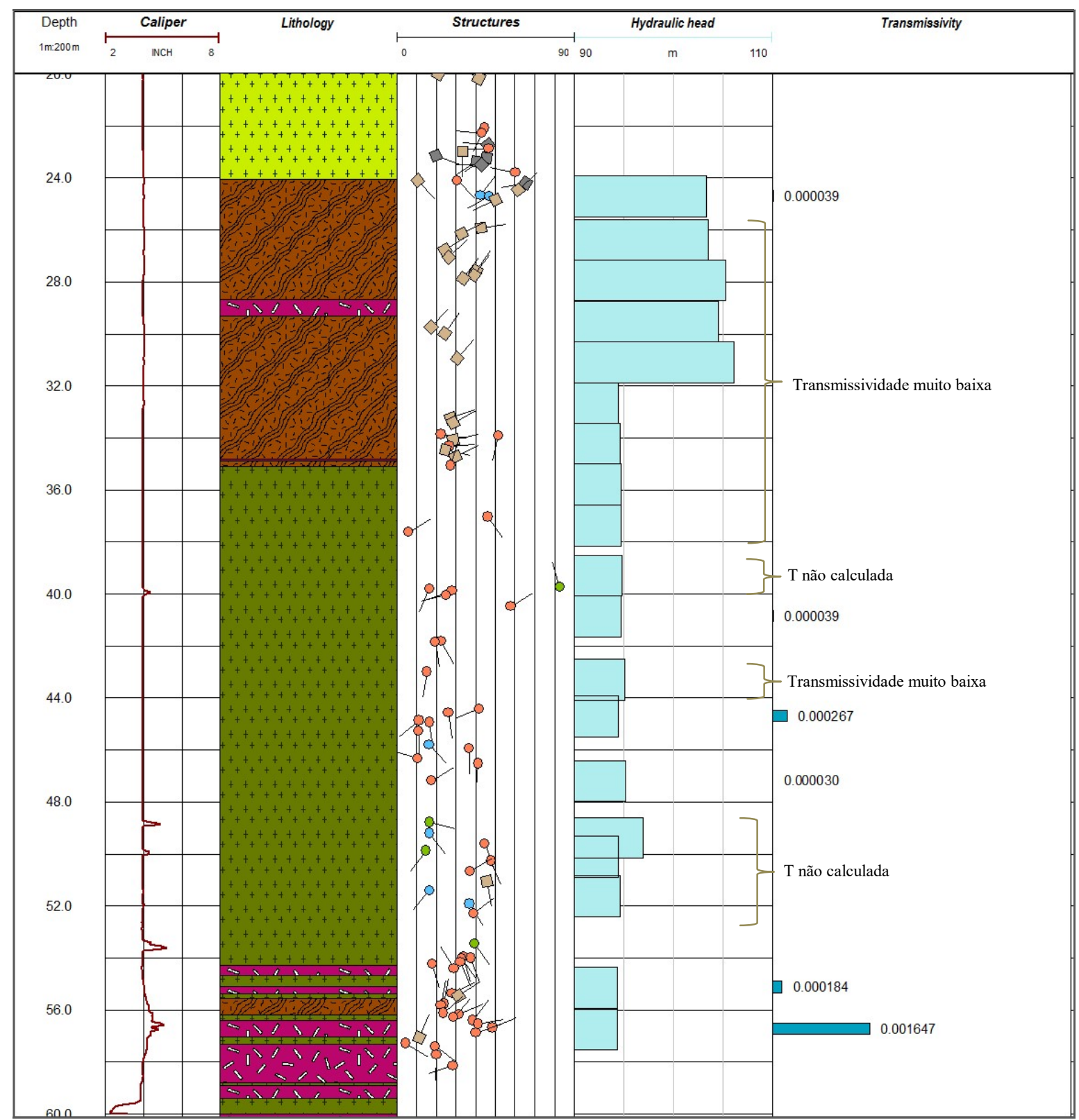

Figura 51 - Perfis obtidos no furo MP-01: calibre, litologia, estruturas, carga hidráulica nos intervalos ensaiados com obturadores, transmissividade calculada $\left(\mathrm{m}^{2} / \mathrm{s}\right)$. Intervalo entre os obturadores de $1.57 \mathrm{~m}$. (Pino, 2017)

\subsubsection{Desenho e Instalação do Poço CMT}

A parte sequencial do processo de investigação em um aquífero fraturado relaciona-se com a instalação de poços de monitoramento multiníveis em alta resolução, cujas definições das profundidades das seções alvo de monitoramento são derivadas das informações obtidas a partir das ferramentas de investigação utilizadas anteriormente (perfilagens geofísicas, descrição estratigráfica, estrutural e de perfil de contaminação em testemunhos de sondagem, ensaios hidráulicos) (Parker, 2007). 
Um poço multinível tipo Continuous Multichannel Tubing - CMT (Einarson \& Cherry, 2002) com sete portas foi instalado, o que permite o monitoramento de cargas hidráulicas e concentrações de solutos em sete diferentes profundidades.

A instalação do poço multinível CMT ocorreu em um novo furo, MP-01C. Este poço foi montado em campo e consiste em um tubo continuo de polietileno de 1,7" de diâmetro (Figura 52a), com seis canais periféricos e um central, com 0,4 " e 3/8" de diâmetro, respectivamente. As informações existentes, derivadas do perfil geológico e de concentração dos dois furos de sondagem realizados, auxiliaram na definição das profundidades das zonas alvo, juntamente com a análise do perfil geológico obtido durante sua perfuração e os resultados do DPIL, citado no item 1.10. O poço CMT foi instalado com $14,5 \mathrm{~m}$, ou seja, dentro da profundidade máxima projetada de $15 \mathrm{~m}$. Foram realizadas as marcações das profundidades de interesse no tubo CMT (Figura 52b) e inseridos plugs de vedação mecânicos na base do tubo, para isolar as portas de monitoramento e prevenir eventual contaminação cruzada.
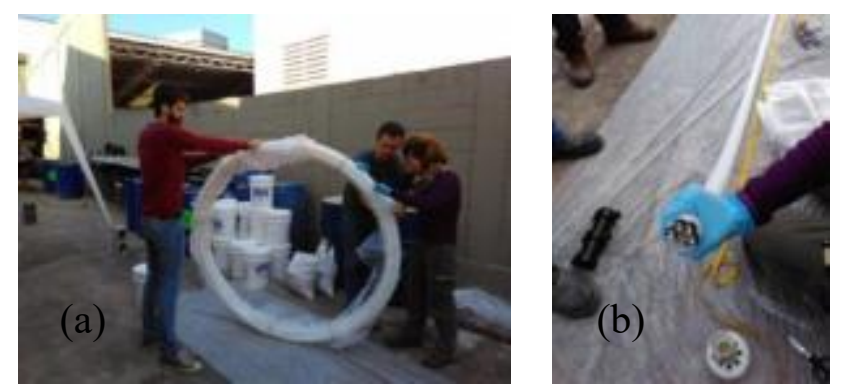

Figura 52 - (a) Preparo do tubo CMT para corte das seções filtrantes (b) Marcação do tubo e fechamento inferior dos canais com plugs

A ferramenta de corte (Figura 53a) padroniza as distâncias entre as aberturas laterais realizadas no tubo. Ela é acoplada na altura da marcação de forma a perfurar apenas o canal periférico de interesse, evitando a comunicação entre os canais (Figura 53b,c).
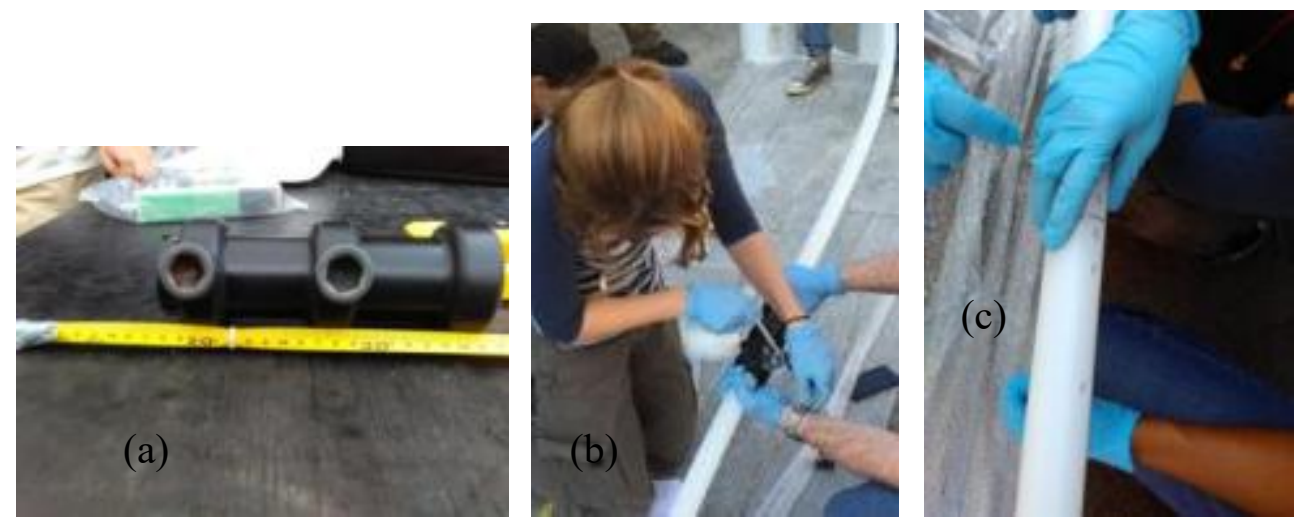

Figura 53 - (a) Ferramenta de corte; (b) corte na altura da marcação; (c) aberturas laterais 
Em seguida é realizado o corte manual para aumento do comprimento da seção filtrante (Figura 54a), por meio do qual é inserido outro plug (Figura 54b), para isolamento do canal de forma a permitir a entrada de água apenas na profundidade escolhida. A Figura 54c apresenta o detalhe da porta de monitoramento com o plug.
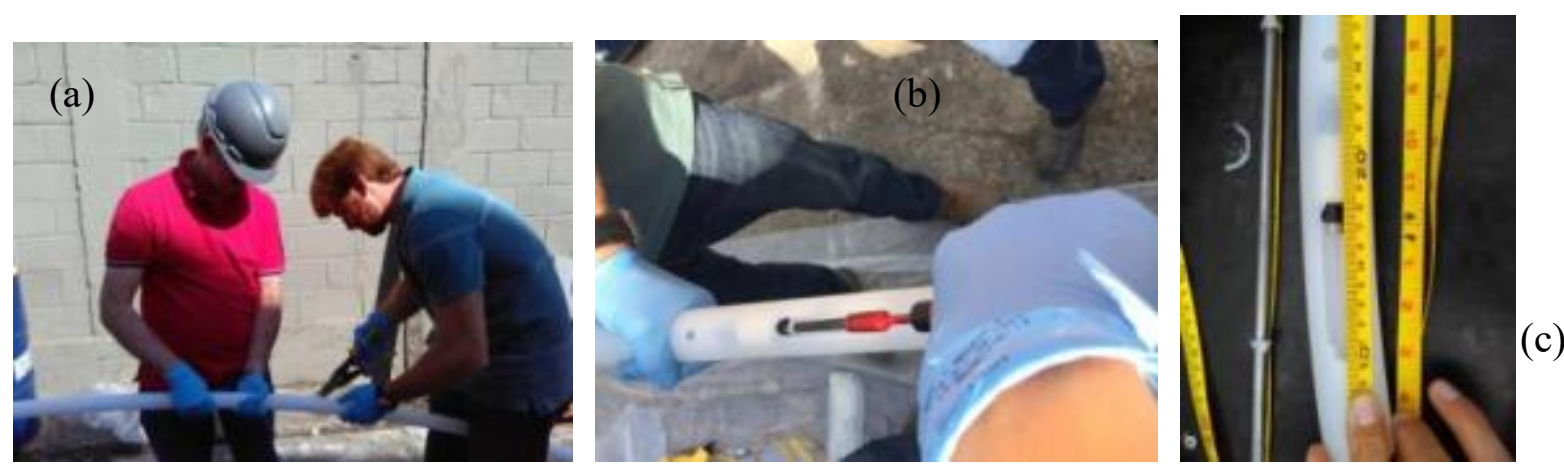

Figura 54 - (a) Corte da seção filtrante (b) Inserção de plug de isolamento (c) Porta de monitoramento

As portas de monitoramento periféricas (Figura 55a) e central (Figura 55b) são revestidas por uma malha de aço inox para evitar a entrada de materiais finos. Também foram acoplados centralizadores de 4,4", indicados na Figura 55a e na Figura 55c pelas setas amarelas, os quais são projetados para favorecer a passagem de bentonita e pré-filtro no espaço anelar entre o tubo e o furo. Após a preparação de todas as portas de monitoramento e centralizadores o conjunto foi inserido no furo (Figura 55c).
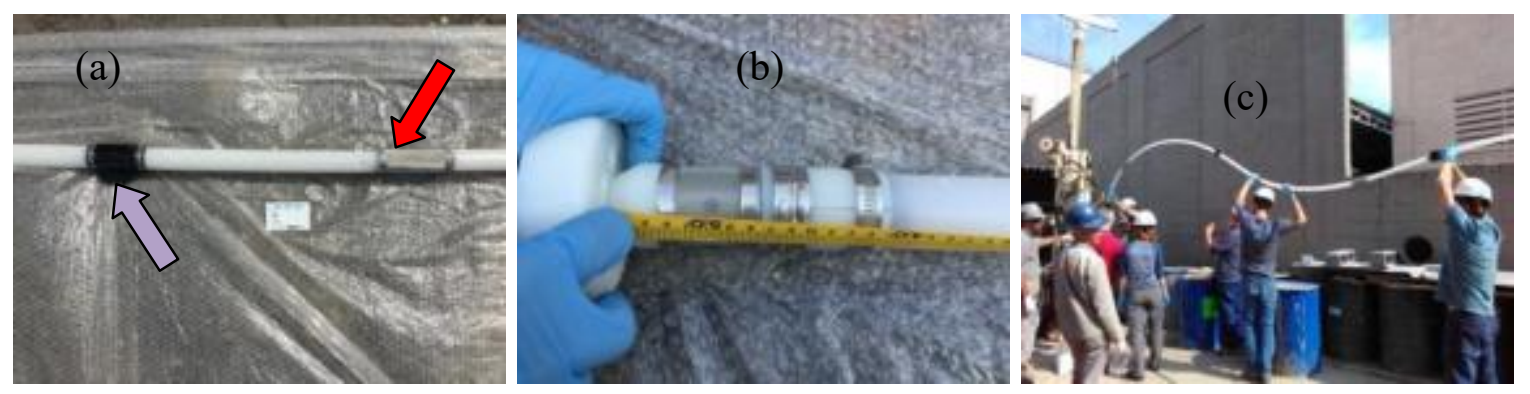

Figura 55 - (a) Centralizador (seta amarela) e porta de monitoramento de um canal periférico (seta vermelha) (b) Porta de monitoramento do canal central (c) Inserção do tubo no furo.

O pré-filtro foi adicionado na altura das portas de monitoramento e no intervalo foram adicionados pellets de bentonita revestida com 1,4" de diâmetro (coated bentonite pellet TR 60 Pel-Plug(), que apresenta hidratação lenta, que previne contra a formação de vazios no selo de 
proteção entre as portas. A Tabela 4 apresenta as características construtivas do CMT, o qual está ilustrado na Figura 56.

Tabela 4 - Características construtivas do poço de monitoramento CMT

\begin{tabular}{c|c|c|c|c|c|c|c}
\hline \multirow{2}{*}{ Poço } & $\begin{array}{c}\text { Profundidade } \\
\text { poço }\end{array}$ & \multicolumn{2}{|c|}{ Seção Filtrante } & \multicolumn{2}{c|}{ Pré-Filtro } & Canal do CMT & Perfuração \\
\cline { 2 - 9 } & $\mathrm{m}$ & $\mathrm{m}$ & $\mathrm{m}$ & $\mathrm{m}$ & $\mathrm{m}$ & ( Ø - pol. $)$ & ( Ø - pol.) \\
\hline CMT-01 & 2,30 & 2,27 & 2,34 & 2,10 & 2,40 & $0,4 "$ & $4 "$ \\
\hline CMT-02 & 3,70 & 3,67 & 3,74 & 3,50 & 3,90 & $0,4 "$ & $4 "$ \\
\hline CMT-03 & 6,20 & 6,17 & 6,24 & 6,00 & 6,40 & $0,4 "$ & $4 "$ \\
\hline CMT-04 & 8,80 & 8,77 & 8,84 & 8,60 & 9,00 & $0,4 "$ & $4 "$ \\
\hline CMT-05 & 10,20 & 10,17 & 10,24 & 10,00 & 10,40 & $0,4 "$ & $4 "$ \\
\hline CMT-06 & 12,20 & 12,17 & 12,24 & 12,00 & 12,40 & $0,4 "$ & $4 "$ \\
\hline CMT-07 & 14,50 & 14,49 & 14,50 & 14,30 & 14,80 & $3 / 8^{\prime \prime}$ & $4 "$ \\
\hline
\end{tabular}

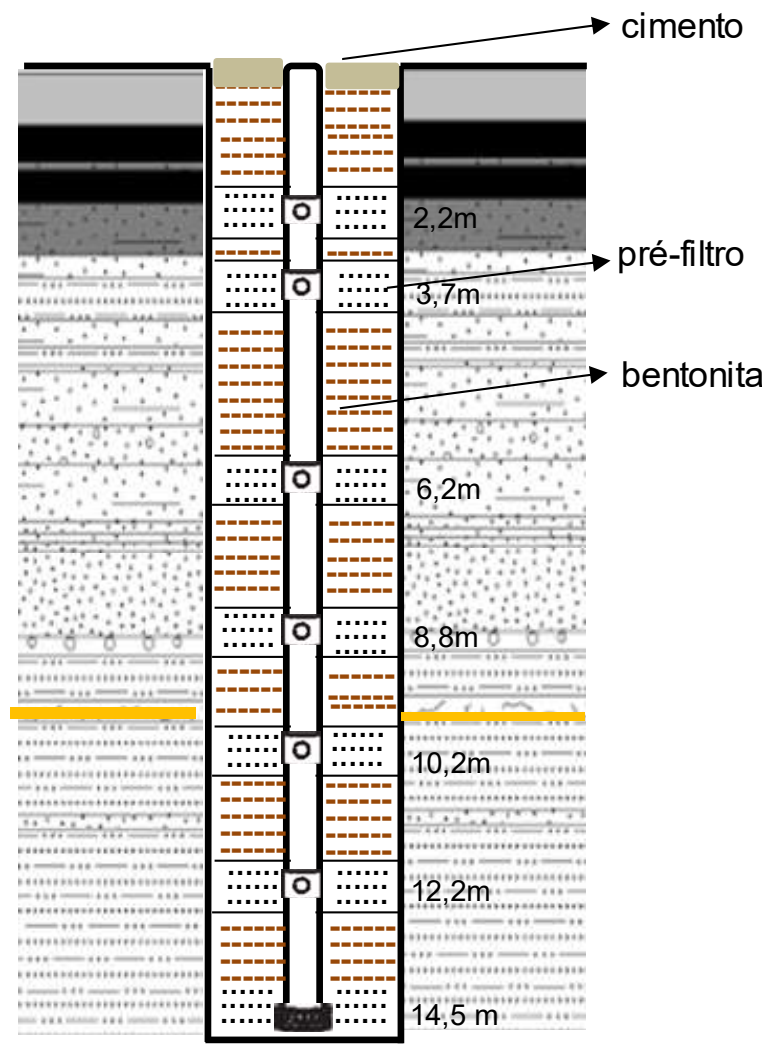

Figura 56 - Perfil construtivo do poço multinível CMT.

\subsubsection{Desenho e Instalação do Poço Westbay}

O poço Westbay foi instalado na sondagem MP-01, onde a lona impermeável FLUTe blank liner encontrava-se instalada. Este liner foi retirado da perfuração com o auxílio da ferramenta green machine (Figura 57). 

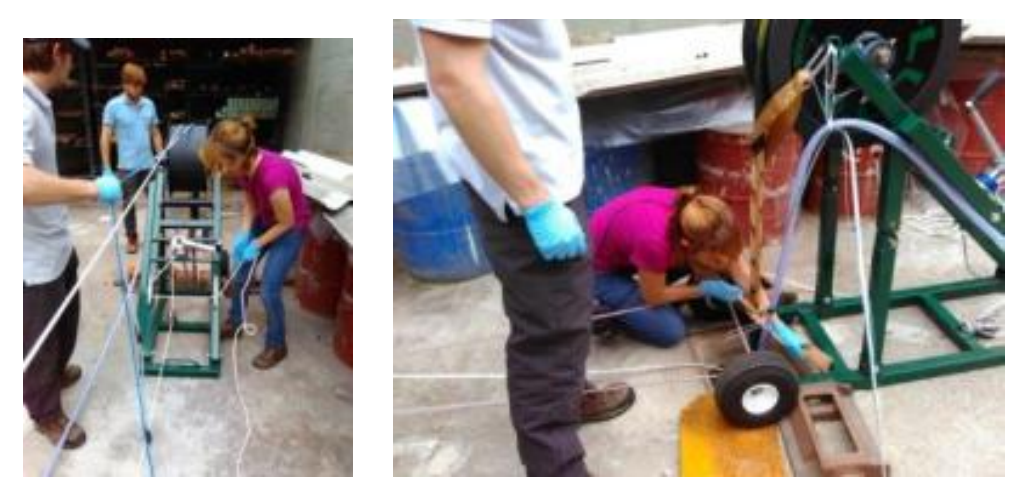

\section{Figura 57 - Remoção do FLUTe blank liner com a green machine}

O sistema Westbay corresponde a um poço multinível pré-montado, conforme o projeto discutivo e aprovado previamente com o fabricante. Os critérios para seleção das portas de monitoramento são derivados dos dados de campo, pela análise dos testemunhos de sondagem e verificação da perda de água de circulação numa dada profundidade, dos dados interpretados das perfilagens executadas e dos dados estruturais (característica da fratura ou família de fraturas em profundidade).

A instalação do poço MP-01 foi executada por um técnico da própria Westbay Instruments. Previamente à instalação, uma filmagem foi realizada para verificação das condições do furo, durante a qual se constatou o acúmulo de material no fundo do furo, que se tornou cerca de $1 \mathrm{~m}$ mais raso. O projeto original do sistema Westbay foi então adaptado para a nova profundidade. $\mathrm{O}$ poço MP-01 possui diâmetro interno de 1,5", 16 portas de monitoramento, as quais são utilizadas para um detalhado mapeamento vertical de carga hidráulica e de concentração de compostos de interesse ao longo do tempo, e outras 6 portas de bombeamento (pumping ports), que podem ser utilizadas para realização de ensaios e testes hidráulicos. As seções de monitoramento são isoladas umas das outras pelo uso de obturadores dedicados (packers) de 0,90 m, evitando eventual contaminação cruzada (Figura 58, tubos verdes). Em campo, foi realizada a medição de comprimento de cada tubo e a checagem da sequência das partes do sistema Westbay, para posterior montagem (Figura 58).
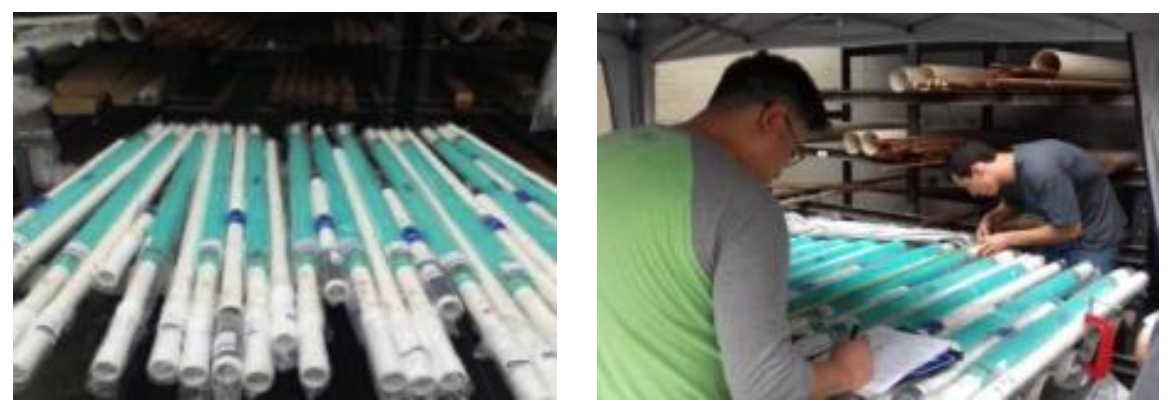

Figura 58 - Checagem de comprimento e sequência de códigos do sistema Westbay. 
Durante a instalação, que consistiu na montagem das peças na boca do poço, todas as conexões foram testadas quanto à sua estanqueidade, bem como o funcionamento das portas de monitoramento, bombeamento e colares magnéticos (Figura 59).
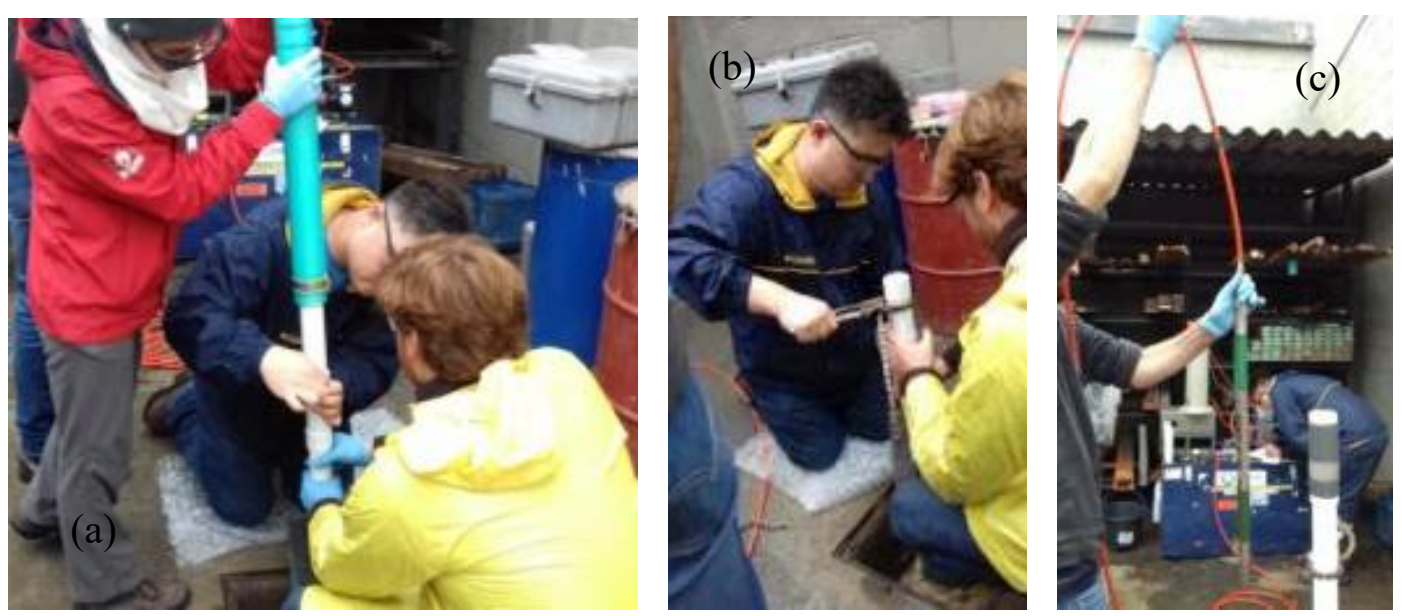

Figura 59 - (a) Montagem na boca do poço, (b) Acoplamento do packer, (c) Ferramenta para teste de estanqueidade.

A Figura 60a indica a entrada de água na porta de monitoramento, por meio da qual é acoplada a sonda que possibilita a obtenção das cargas hidráulicas e a coleta de água subterrânea. A Figura 60b ilustra o colar magnético entre as portas de monitoramento e bombeamento, para assegurar que a sonda pouse na profundidade adequada.
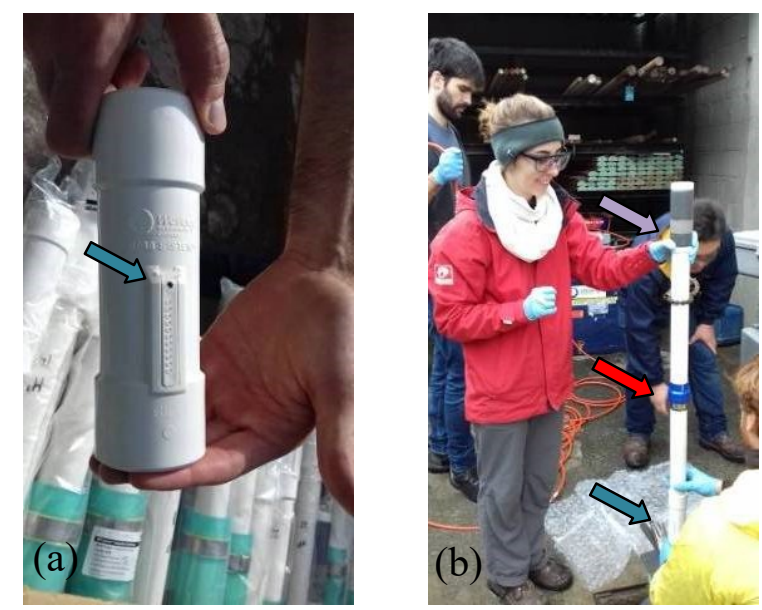

Figura 60 - (a) Porta de monitoramento. Seta azul indica a entrada de água (b) Porta de bombeamento (seta amarela); colar magnético (seta vermelha) e porta de monitoramento (seta azul).

Durante o monitoramento e/ou amostragem, a sonda (Figura 61a) conecta-se à interface MAGI - MOSDAX Automated Groundwater Interface (Figura 61b), a qual envia os sinais para pouso na profundidade de interesse e acoplamento da sonda na porta de monitoramento para medição da pressão de fluido, posteriormente convertida em coluna d'água. A MAGI também permite acionar a abertura e fechamento da válvula da sonda para a amostragem de água 
subterrânea. É utilizado um tripé (Figura 61c) para controlar a descida da sonda na profundidade adequada, a qual também emite um sinal sonoro ao passar pelo colar magnético, evitando o monitoramento de portas por engano.
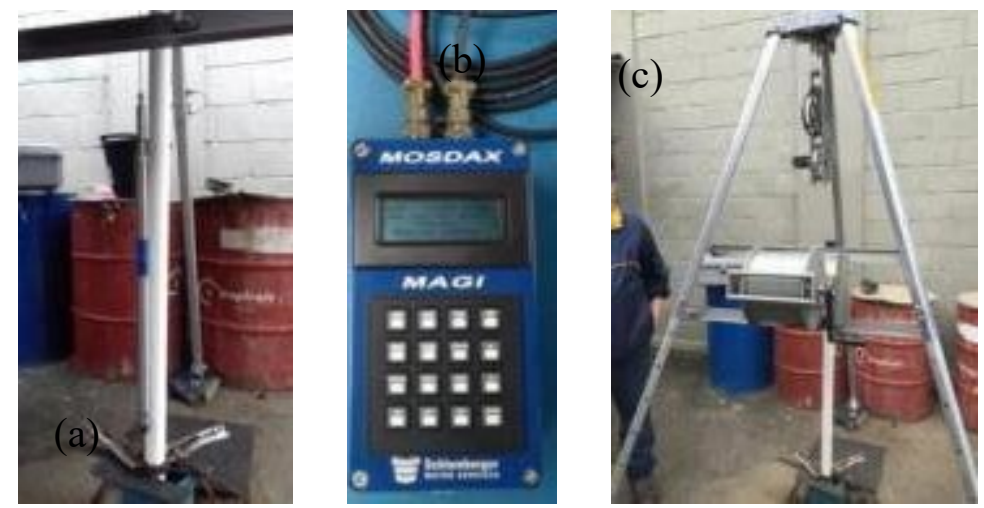

Figura 61 - (a) Sonda de amostragem (b) MAGI interface da sonda (c) tripé para controlar a descida da sonda

A Figura 62 apresenta o perfil construtivo do poço Westbay MP-01 e a indicação das 16 portas de monitoramento, 6 portas de bombeamento e 6 colares magnéticos.

\subsubsection{Monitoramento de cargas hidráulicas dos sistemas multiníveis}

Desde sua instalação em junho-2016, as cargas hidráulicas dos poços Westbay e CMT tem sido monitoradas (Figura 63). Observa-se que um aumento inicial do valor de carga hidráulica nesses poços que reflete a estabilização dos sistemas após a instalação e a purga dos poços para a campanha de amostragem de água subterrânea. Entre dezembro e janeiro, a elevação da carga hidráulica deve-se ao período de recarga.

A continuidade do monitoramento das cargas do CMT e do Westbay deverá contribuir com o esclarecimento do comportamento hidráulico das camadas onde estão as portas de cada um dos sistemas. 


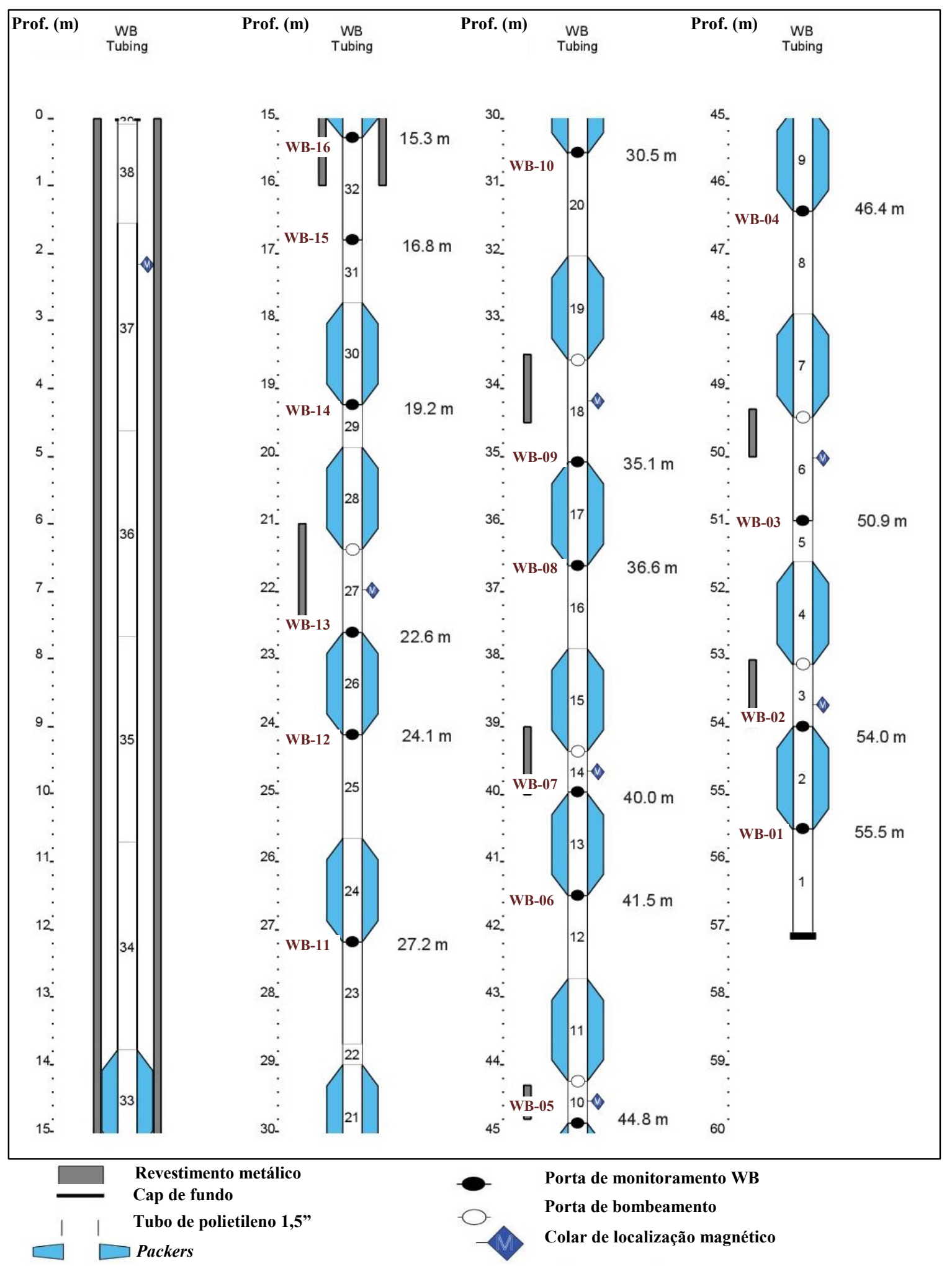

Figura 62 - Perfil construtivo do poço multinível Westbay MP-01. 


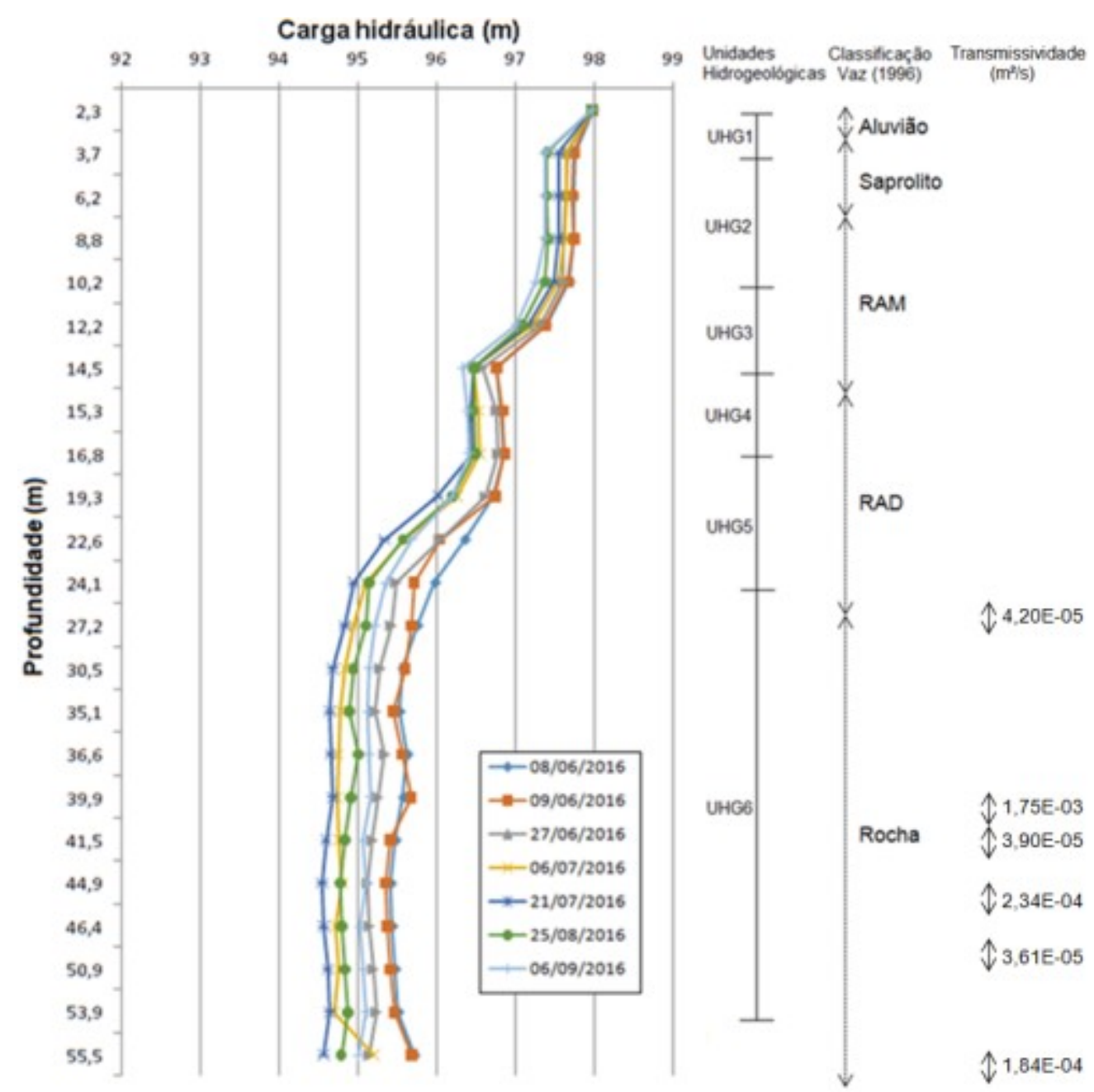

Figura 63 - Monitoramento de cargas hidráulicas dos poços multiníveis CMT e Westbay.

\subsubsection{Amostragem de água subterrânea}

Uma campanha de coleta de amostras de água subterrânea nos sistemas multiníveis CMT e Westbay foi realizada até o momento, assim como de poços de monitoramento convencionais situados nas proximidades. Em todos os pontos foram realizadas medições de parâmetros físicoquímicos com auxílio de equipamento multiparâmetros, previamente calibrados: temperatura, condutividade elétrica, $\mathrm{pH}$, potencial de oxido-redução e oxigênio dissolvido.

No sistema Westbay e CMT, foram coletadas amostras para análises de íons maiores e isótopos $\sigma 18 \mathrm{O}$ e $\sigma 2 \mathrm{H}$ nos laboratórios do CEPAS - IGc USP; carbono orgânico total (TOC/NPOC) no laboratório do Semi Industrial da Poli Química - USP, gases dissolvidos, ferro total e filtrado, manganês total e filtrado, sulfeto e compostos orgânicos voláteis no laboratório Analytical Technology; e isótopos ${ }^{13} \mathrm{C}$ e ${ }^{37} \mathrm{Cl}$ de compostos clorados (CSIA), no laboratório IT 
Technologies (Waterloo, Canadá). Nos poços convencionais, com exceção dos isótopos, os demais parâmetros também foram analisados.

Nos poços de monitoramento PM-10; PM-10B, PM-11, PM-11A, PM-11B, PM-18, PM18A, PM-18B, a coleta foi realizada utilizando-se a metodologia de amostragem em baixa vazão (low flow) através de bomba peristáltica (Figura 64a) acoplada a célula de fluxo, para medição dos parâmetros físico-químicos. Ao todo foram coletadas 8 amostras de poços convencionais, juntamente com amostras de controle de qualidade (branco de campo, branco de equipamento e duplicata).

No sistema CMT, a coleta de amostras de água foi realizada com o auxílio de uma mini bomba inercial para mangueiras descartáveis de 1/4" de diâmetro (Figura 64b), após a purga de três vezes o volume do poço e/ou sua purga total. A mini bomba inercial foi descontaminada previamente em cada ponto de amostragem com detergente não fosfatado Extran MA02 Neutro e água mineral engarrafada, com baixo teor de sólidos dissolvidos.

Devido ao rebaixamento do aquífero em função de variações sazonais, a porta CMT-01 estava sem coluna d'água e não foi amostrado nessa campanha, totalizando 6 amostras dos poços CMT-02 ao CMT-07, além de amostras de controle de qualidade (branco de campo, branco de equipamento e duplicata). No sistema Westbay, a coleta de amostras de água foi realizada com o auxílio de canisters (Figura 64c) conectados à sonda. Os canisters são compartimentos de aço inoxidável, com capacidade de cerca de $250 \mathrm{~mL}$, que podem ser conectados por um tubo flexível, com teflon e sistema de anéis de vedação para evitar vazamento de ar e/ou água no sistema (Figura 64d). Desta forma, podem ser conectados até quatro canisters em série, para coleta de até $1 \mathrm{~L}$ por manobra.

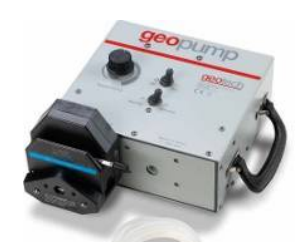

(a)
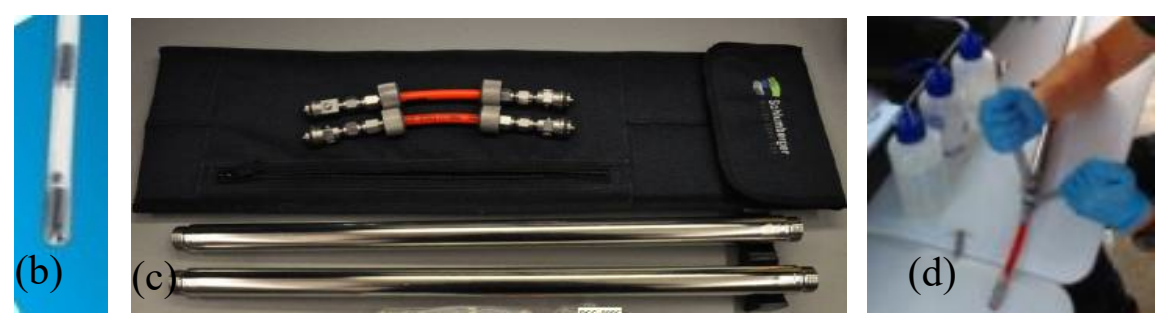

Figura 64 - Monitoramento de cargas hidráulicas dos poços multiníveis CMT e Westbay.

Em superfície, provoca-se redução na pressão interna do sistema da sonda acoplada aos canisters para que, na profundidade de interesse, a água da zona de monitoramento entre no sistema por diferença de pressão. Ao acessar a porta de monitoramento, são medidas as pressões do tubo e da formação e a válvula da sonda, acionada via MAGI (Figura 61). A pressão da 
formação é mantida até atingir a superfície, quando a válvula é aberta manualmente nos canisters, para o acondicionamento da amostra.

Os canisters e demais equipamentos que mantiveram contato com a água subterrânea são descontaminados previamente, entre os pontos de amostragem, com detergente não fosfatado e água destilada. No MP-01 foram coletadas 16 amostras das portas WB-01 a WB-16, bem como amostras de controle de qualidade (branco de campo, branco de equipamento e duplicata).

Nesta campanha, foram coletadas amostras de água subterrânea de 30 pontos distintos, para obtenção dos parâmetros físico-químicos, caracterização geoquímica, avaliação do perfil de contaminação por compostos orgânicos voláteis, gases metano, etano e eteno, análises isotópicas, bem como amostras de controle de qualidade.

\subsubsection{Resultados analíticos de água subterrânea}

Os dados geoquímicos relacionados à avaliação do potencial redox para os horizontes de monitoramento associados ao manto de alteração do embasamento cristalino são apresentados na Tabela 5 (CMT e poços de monitoramento convencionais).

Tabela 5 - Parâmetros REDOX e dados de campo (sistema CMT, PM11-A e PM-11B).

\begin{tabular}{|c|c|c|c|c|c|c|c|c|}
\hline & СMT02 & CMT03 & СMT04 & CMT05 & СMT06 & СМT07 & PM11A & PM11B \\
\hline Condutividade Elétrica $(\mu \mathrm{s} / \mathrm{cm})$ & 2031 & 4371 & 1405 & 2001 & 2357 & 2637 & 0,12 & 511 \\
\hline pH & 6,26 & 7,28 & 6,55 & 6,44 & 6,73 & 6,96 & 3,05 & 5,77 \\
\hline ORP (mV) & $-63,3$ & $-51,4$ & $-95,4$ & $-70,3$ & $-109,3$ & -113 & 5,49 & 62,7 \\
\hline $\mathrm{NO}_{3}^{-}(\mathrm{mg} / \mathrm{L})$ & 0,33 & 0,84 & 0,14 & 7,37 & 0,05 & 0,88 & 0,03 & 0,06 \\
\hline $\mathrm{NH}_{4}{ }^{+}(\mathrm{mg} / \mathrm{L})$ & 7,68 & 0,50 & 0,21 & 0,57 & 0,68 & 0,71 & 0,05 & 0,03 \\
\hline Mn total $(\mu \mathrm{g} / \mathrm{L})$ & 772,5 & 2061,6 & 3250 & 2924,2 & 2133,2 & 3069,7 & 173,7 & 688,4 \\
\hline Mn diss olvido $(\mu \mathrm{g} / \mathrm{L})$ & 704 & 1284 & 2911 & 4052 & 96,9 & $<10,0$ & 134 & 492 \\
\hline Fe total $(\mu \mathrm{g} / \mathrm{L})$ & 99642,5 & 129603,9 & 87777,3 & 48427,1 & 47201,2 & 88813,1 & 11850,2 & 68315,2 \\
\hline Fe dis solvido $(\mu \mathrm{g} / \mathrm{L})$ & 87632 & 12237 & 33678 & 5299 & 109 & $<30,0$ & 8699 & 45902 \\
\hline $\mathrm{SO}_{4}^{2-} \mathrm{mg} / \mathrm{L}$ & 1,6122 & 62,4891 & 18,2764 & 92,9406 & 114,7131 & 48,779 & 0,1377 & 0,9603 \\
\hline S- mg/L & 0,026 & 1,6 & 0,068 & 0,021 & 0,186 & 1,89 & $<0,005$ & $<0,005$ \\
\hline $\mathrm{CH}_{4}{ }^{+} \mu \mathrm{g} / \mathrm{L}$ & 0,566 & 0,149 & $<0,060$ & 0,273 & $<0,060$ & $<0,060$ & 0,089 & $<0,060$ \\
\hline $\mathrm{TOC} \mathrm{mg} / \mathrm{L}$ & 124,5 & 313,2 & 124,3 & 149,9 & 200,2 & 248,5 & 40,85 & 68,4 \\
\hline
\end{tabular}

*ORP: Potencial de óxi-redução; $\mathrm{NO}_{3}{ }^{-}$: Nitrato; $\mathrm{NH}_{4}{ }^{+}$: Amônio; $\mathrm{Mn}$ : Manganês; Fe: Ferro; $\mathrm{SO}_{4}{ }^{2-}$

: Sulfato; S-: Sulfeto; $\mathrm{CH}_{4}^{+}$: Metano e TOC: Carbono Orgânico Total

Dados construtivos do poço CMT: ver Tabela 4 e Figura 56.

Elevados valores de condutividade e $\mathrm{pH}$ foram obtidos, além de valores mais negativos de ORP junto aos horizontes de monitoramento do CMT em relação aos poços de monitoramento convencionais (PM-11A - seção filtrante entre 7,8- 8,8m e PM-11B - seção filtrante entre 13,214,2m), que se encontram horizontalmente a 2 metros de distância do sistema CMT. 
Adicionalmente, se observa condições mais redutoras junto aos poços CMT, evidenciadas pelas concentrações de TOC, metano, sulfeto, amônio, manganês dissolvido e ferro, sugerindo a presença de um ambiente ferro-sulfato redutor.

A hipótese mais provável é a de que houve uma interferência na hidroquímica do meio induzida pela bentonita utilizada na construção do poço CMT, considerando a forte heterogeneidade existente entre os dados do CMT e dos poços convencionais, mesmo em profundidades similares. Esta interferência é associada ao TOC e a outros íons em solução, evidenciados pelos elevados valores de condutividade elétrica.

Os resultados de análises de água subterrânea de VOCs (Figura 65) indicam pela presença de compostos de degradação (predomínio de cis-1,2-DCE e cloreto de vinila) junto aos horizontes do CMT, em concentrações expressivas. Por sua vez, os poços multiníveis convencionais apresentam predominância de PCE, também com concentrações significativas de VOCs Totais.

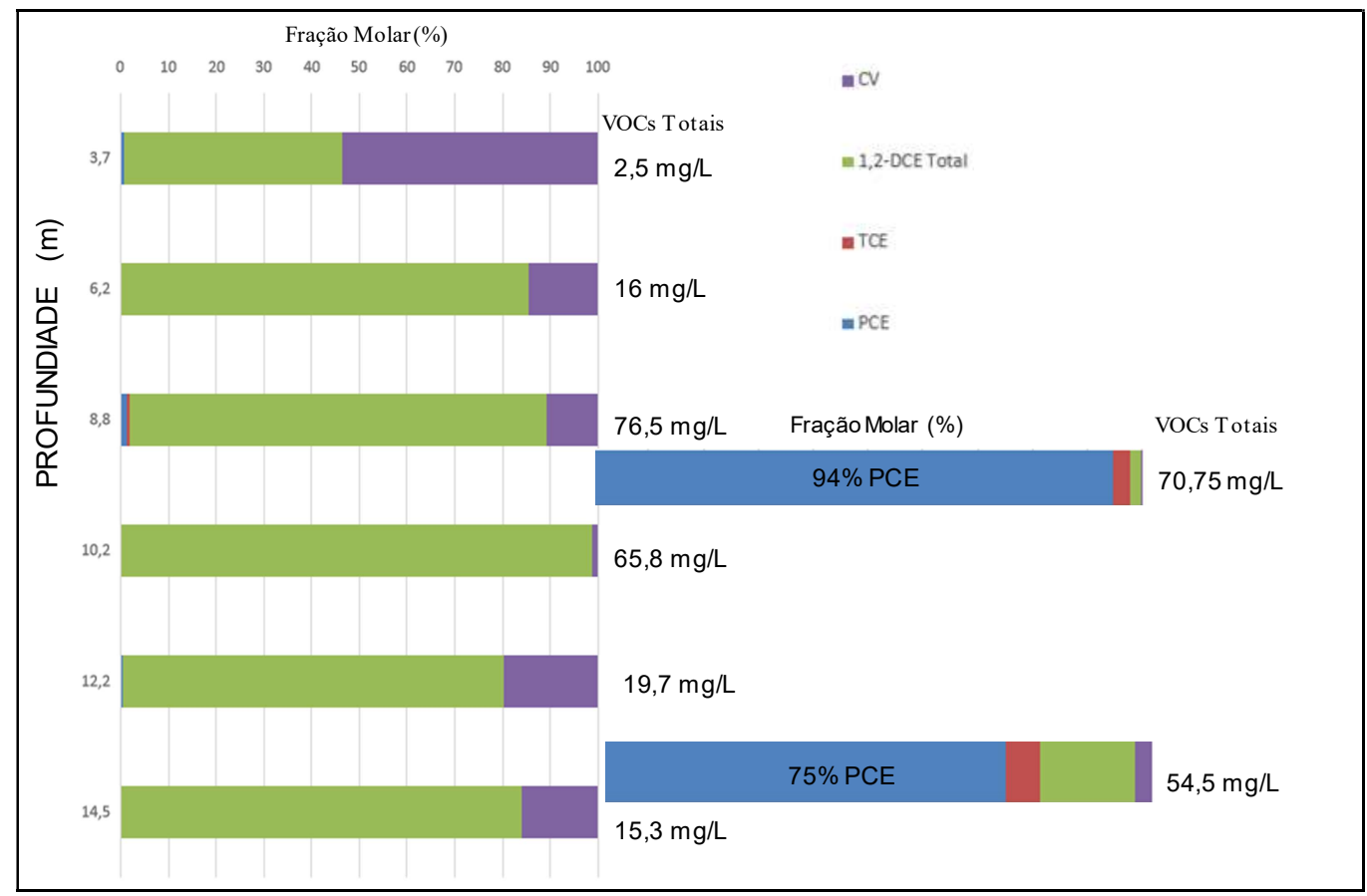

Figura 65 - Fração Molar e VOCs totais: Solo Residual (CMT e poços multiníveis).

Os dados hidroquímicos provenientes do aquífero fraturado no sistema Westbay (Tabela 6) não apresentam de forma clara o mesmo padrão de interferência observado junto aos poços CMT. Condições levemente redutoras predominam, o que sugere a ocorrência de um ambiente ferro-redutor. Os resultados de análises de VOCs do sistema Westbay (Tabela 7 e Figura 66) indicam a presença de compostos de degradação (predomínio de cis-1,2-DCE e cloreto de vinila) 
até uma profundidade de aproximadamente $22,6 \mathrm{~m}$. Estas concentrações parecem ser semelhantes à assinatura verificada na porção basal do sistema multinível CMT, via fluxo vertical descendente, mesmo na ausência de TOC e anomalias de condutividade elétrica. De qualquer forma, é notável observar a ocorrência de elevadas concentrações de VOCs totais ao longo de toda a perfuração, com elevação dessas nas portas mais profundas do sistema Westbay, entre 50,9 e 55,5 m, sugerindo que os solventes halogenados migraram até essas profundidades como fase livre não-aquosa através da rede de fraturas.

Tabela 6 - Parâmetros REDOX e dados de campo - Poço Westbay

\begin{tabular}{|c|c|c|c|c|c|c|c|c|c|c|c|c|c|c|c|c|}
\hline & WB16 & WB15 & WB14 & WB13 & WB12 & WB11 & WB10 & WB09 & WB08 & WB07 & WB06 & WB05 & WB04 & WB03 & WB02 & WB01 \\
\hline Profundidade (m) & 15,3 & 16,8 & 19,3 & 22,6 & 24,1 & 27,2 & 30,5 & 35,1 & 36,6 & 39,9 & 41,5 & 44,9 & 46,4 & 50,9 & 53,9 & 55,5 \\
\hline Condutividade Elétrica $(\mu \mathrm{s} / \mathrm{cm})$ & 583 & 707 & 702 & 677,2 & 325,3 & 316,2 & 265,2 & 319,2 & 180 & 865 & 253,4 & 299,5 & 97,4 & 546 & 791 & 668 \\
\hline $\mathrm{pH}$ & 6,87 & 6,8 & 6,53 & 6,55 & 6,1 & 6,07 & 6,73 & 6,22 & 6,72 & 6,03 & 7,03 & 7,13 & 6,58 & 6,68 & 6,88 & 6,63 \\
\hline ORP $(\mathrm{mV})$ & $-61,1$ & $-94,2$ & $-76,5$ & $-71,4$ & $-5,5$ & -34 & $-48,6$ & $-43,3$ & $-48,7$ & $-32,2$ & $-50,1$ & $-74,2$ & $-56,6$ & $-24,5$ & $-22,4$ & $-43,2$ \\
\hline NO3- (mg/L) & 0,04 & 0,05 & 0,19 & 0,08 & 0,20 & 0,06 & 0,19 & 0,04 & 0,13 & 0,08 & 0,05 & 0,09 & 0,04 & 0,05 & 0,09 & 0,03 \\
\hline $\mathrm{NH4}+(\mathrm{mg} / \mathrm{L})$ & 0,87 & 0,02 & 0,03 & 0,04 & 0,02 & 0,03 & 0,03 & 0,04 & 0,01 & 0,18 & 0,12 & 0,15 & 0,04 & 0,21 & 0,23 & 0,12 \\
\hline Mn total $(\mu \mathrm{g} / \mathrm{L})$ & 233,8 & 3504,2 & 4557,6 & 3455,4 & 1659 & 914,6 & 950,8 & 1043,2 & 149 & 1021,3 & 716,4 & 608,9 & 240,2 & 1074,7 & 903,3 & 1321,7 \\
\hline Mn dissolvido $(\mu \mathrm{g} / \mathrm{L})$ & 219 & 2668 & 4525 & 3419 & 1362 & 763 & 670 & 780 & 700 & 1016 & 495 & 452 & 183 & 823 & 724 & 1089 \\
\hline Fe total $(\mu \mathrm{g} / \mathrm{L})$ & 11042,4 & 134021,7 & 50673,9 & 36652,2 & 8585,9 & 3892,4 & 3422,8 & 13301,6 & 248,8 & 13033,6 & 5413,9 & 4062,7 & 1644,6 & 5378,9 & 18315,2 & 4689,1 \\
\hline Fe dissolvido $(\mu \mathrm{g} / \mathrm{L})$ & 1460 & 81630 & 25145 & 20136 & 6725 & 3422 & 2625 & 4496 & 3868 & 12770 & 3889 & 3097 & 1274 & 4402 & 17197 & 3994 \\
\hline $\mathrm{SO}_{4}{ }^{2-} \mathrm{mg} / \mathrm{L}$ & 0,10 & 0,22 & 0,76 & 0,27 & 2,13 & 3,18 & 1,82 & 2,26 & 10,80 & 82,34 & 30,99 & 42,54 & 4,53 & 54,29 & 79,75 & 114,49 \\
\hline S- $\mathrm{mg} / \mathrm{L}$ & $<0,005$ & $<0,005$ & $<0,005$ & $<0,005$ & $<0,005$ & $<0,005$ & $<0,005$ & $<0,005$ & $<0,005$ & $<0,005$ & $<0,005$ & $<0,005$ & $<0,005$ & $<0,005$ & $<0,005$ & $<0,005$ \\
\hline $\mathrm{CH}_{4}{ }^{+} \mu \mathrm{g} / \mathrm{L}$ & $<0,060$ & 0,286 & $<0,060$ & $<0,060$ & $<0,060$ & $<0,060$ & $<0,060$ & $<0,060$ & $<0,060$ & $<0,060$ & $<0,060$ & $<0,060$ & $<0,060$ & $<0,060$ & $<0,060$ & $<0,060$ \\
\hline $\mathrm{TOC} \mathrm{mg/L}$ & 19,62 & 6,794 & 68,63 & 54,01 & 32,47 & 26,78 & 25,71 & 23,33 & 9,835 & 24,8 & 20,66 & 27,94 & 13,05 & 34,94 & 36,23 & 56,5 \\
\hline
\end{tabular}

Tabela 7 - Resultados das análises de etenos clorados de água subterrânea

\begin{tabular}{|c|c|c|c|c|c|c|c|c|}
\hline Portas/Poços & Profundidade & PCE & TCE & 1,1-DCE & t-1,2-DCE & c-1,2-DCE & CV & VOC Total \\
\hline & (m) & $(\mu g / L)$ & $(\mu \mathrm{g} / \mathrm{L})$ & $(\mu \mathrm{g} / \mathrm{L})$ & $(\mu \mathrm{g} / \mathrm{L})$ & $(\mu g / \mathrm{L})$ & $(\mu g / \mathrm{L})$ & $(\mu g / \mathrm{L})$ \\
\hline CMT02 & 3,7 & 42,1 & $<3,00$ & $<3,00$ & $<3,00$ & 1391,2 & 1055,7 & 2489 \\
\hline CMTO3 & 6,2 & 13,6 & $<3,00$ & 20,9 & 11,2 & 14460,4 & 1583,1 & 16089,2 \\
\hline CMT04 & 8,8 & 1852,2 & 411,9 & 163,5 & 28,6 & 68731,1 & 5468,8 & 76656,1 \\
\hline CMT05 & 10,2 & $<3,00$ & $<3,00$ & 57,6 & 19 & 65223,1 & 526,2 & 65825,9 \\
\hline CMT06 & 12,2 & 107,9 & 27,5 & 44,2 & 21,7 & 16895 & 2675 & 76656,1 \\
\hline CMT07 & 14,5 & $<3,00$ & $<3,00$ & 46,5 & 22,6 & 13557,9 & 1653,3 & 15280,3 \\
\hline WB16 & 15,3 & $<3,00$ & $<3,00$ & $<3,00$ & $<3,00$ & 2972,1 & 128,6 & 3100,7 \\
\hline WB15 & 16,8 & $<3,00$ & $<3,00$ & 28,3 & 103,6 & 29264,4 & 2066 & 31462,3 \\
\hline WB14 & 19,3 & 24,6 & $<3,00$ & $<3,00$ & 11,3 & 4146,7 & 886,9 & 5069,5 \\
\hline WB13 & 22,6 & $<3,00$ & $<3,00$ & $<3,00$ & $<3,00$ & 56,8 & 626,2 & 683 \\
\hline WB12 & 24,1 & 3657,9 & 533,5 & $<3,00$ & $<3,00$ & 3810,3 & 403,6 & 8405,3 \\
\hline WB11 & 27,2 & $<3,00$ & $<3,00$ & $<3,00$ & $<3,00$ & 1613,5 & 154,7 & 1768,2 \\
\hline WB10 & 30,5 & $<3,00$ & $<3,00$ & $<3,00$ & $<3,00$ & 2873,1 & 434,5 & 3307,6 \\
\hline WB09 & 35,1 & 148,4 & 75,4 & $<3,00$ & $<3,00$ & 1663,1 & 96,1 & 1983 \\
\hline WB08 & 36,6 & $<3,00$ & $<3,00$ & $<3,00$ & $<3,00$ & 482,8 & 45,5 & 528,3 \\
\hline WB07 & 39,9 & 21,3 & $<3,00$ & $<3,00$ & $<3,00$ & 4538,2 & 199,5 & 4759 \\
\hline WB06 & 41,5 & $<3,00$ & $<3,00$ & $<3,00$ & $<3,00$ & 1065,7 & 64,4 & 1130,1 \\
\hline WB05 & 44,9 & $<3,00$ & $<3,00$ & $<3,00$ & $<3,00$ & 493,2 & 332,1 & 825,3 \\
\hline WB04 & 46,4 & $<3,00$ & $<3,00$ & $<3,00$ & $<3,00$ & 514,2 & 58,8 & 573 \\
\hline WB03 & 50,9 & 2264,4 & 416,7 & $<3,00$ & $<3,00$ & 4030,5 & 162,4 & 6874 \\
\hline WB02 & 53,9 & 683,1 & $<3,00$ & $<3,00$ & $<3,00$ & 3988,9 & 833,2 & 5505,2 \\
\hline WB01 & 55,5 & 3144,3 & $<3,00$ & 18,8 & $<3,00$ & 5495,8 & 1043,2 & 9702,1 \\
\hline PM10 & 2,8 & $<3,00$ & $<3,00$ & $<3,00$ & $<3,00$ & $<3,00$ & $<1,50$ & - \\
\hline PM10B & 9,6 & $<3,00$ & $<3,00$ & $<3,00$ & $<3,00$ & 74,5 & 230,5 & 305 \\
\hline PM11 & 3 & $<3,00$ & $<3,00$ & $<3,00$ & $<3,00$ & $<3,00$ & $<1,50$ & - \\
\hline PM11A & 8,3 & 68083,1 & 1713 & $<3,00$ & $<3,00$ & 920,9 & 14 & 70731 \\
\hline PM11B & 13,8 & 44664,5 & 3018,4 & 40,2 & 32,9 & 6143,5 & 692,4 & 54591,9 \\
\hline PM18 & 2,5 & $<3,00$ & $<3,00$ & $<3,00$ & $<3,00$ & $<3,00$ & $<1,50$ & - \\
\hline PM18A & 6,5 & $<3,00$ & $<3,00$ & $<3,00$ & $<3,00$ & 45,8 & 17 & 62,8 \\
\hline PMI18B & 9,7 & 419,7 & 104,1 & $<3,00$ & $<3,00$ & 286,7 & $<1,50$ & 810,5 \\
\hline
\end{tabular}




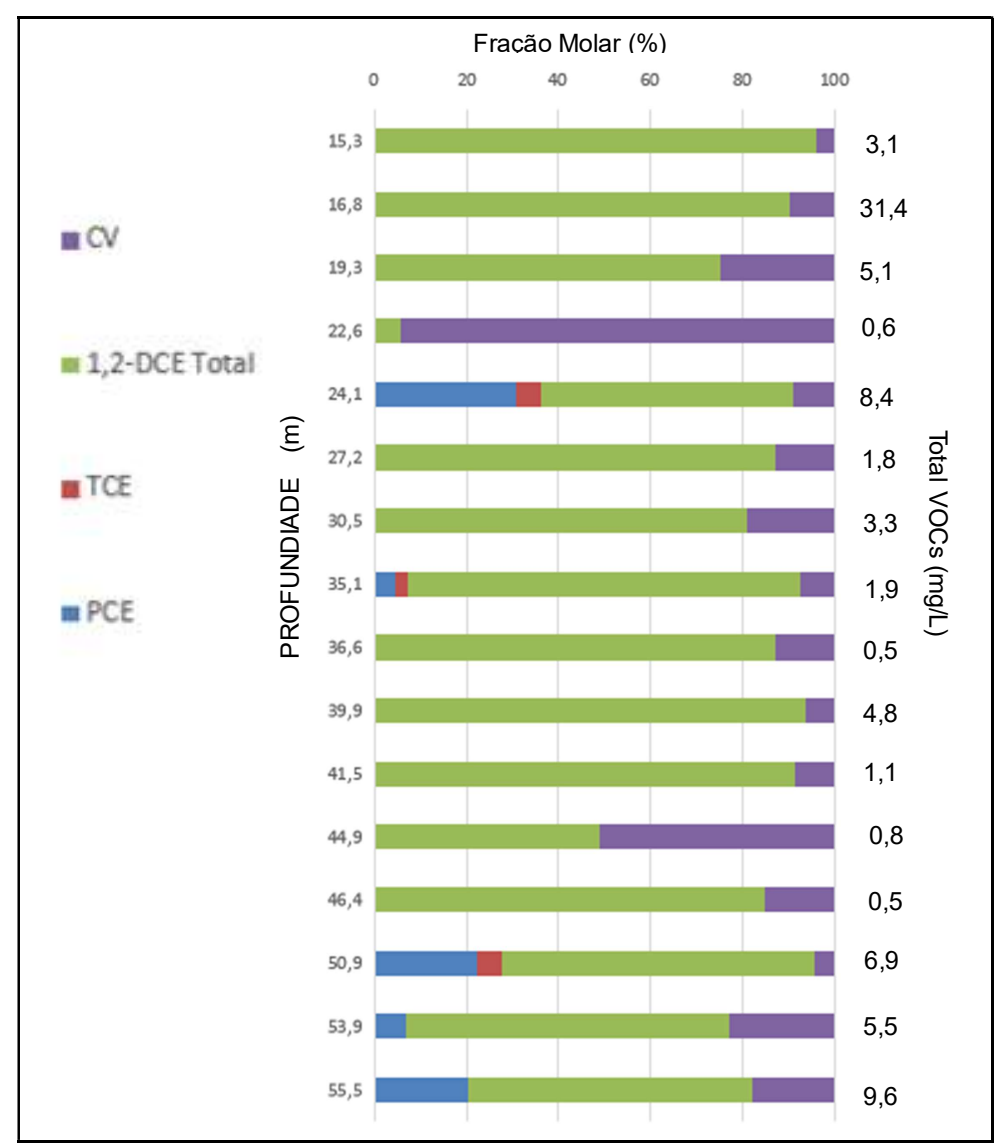

Figura 66 - Fração Molar e VOCs totais: Embasamento Cristalino (Westbay).

\subsubsection{Avaliação da Atenuação Natural}

Um dos objetivos definidos para o projeto de caracterização de superdetalhe da contaminação do aquífero fraturado em Jurubatuba é o de se determinar a possível ocorrência e a intensidade do fenômeno de atenuação natural dos compostos organoclorados, em especial aqueles processos microbiológicos responsáveis pela decloração redutiva anaeróbica (Figura 5, item 2.1). O mestrado de Ferreira (2015) vem sendo desenvolvido para este fim, utilizando-se de dados produzidos através de poços de monitoramento convencionais e dos sistemas multiníveis CMT e Westbay instalados na empresa Ergomat. Os dados necessários para a avaliação estão ainda em processo de produção. Os objetivos específicos do trabalho relacionam-se com a identificação das taxas de biodegradação e a identificação de biomarcadores e tipos de microrganismos que participam do processo de biodegradação.

As taxas de biodegradação serão avaliadas através de ensaios de microcosmos, utilizando amostras de água subterrânea e de solo ou rocha alterada das perfurações. O experimento de laboratório é montado em frascos para cada ponto de amostragem e corresponde a: 
- Microcosmo de solo/rocha desagregada esterilizados com água destilada (controle negativo);

- Microcosmo de solo/rocha desagregada com água subterrânea da mesma profundidade, representando o cenário de possível degradação biótica e abiótica somados;

- Microcosmo de solo/rocha desagregada com água subterrânea da mesma profundidade e com inibidores metabólicos de atividade microbiana, para avaliar o possível cenário de degradação abiótica (Figura 5);

- Microcosmo de solo/rocha desagregada com água subterrânea da mesma profundidade e com aditivos (fonte de carbono) para estimular a biodegradação.

A identificação de biomarcadores e de tipos de microrganismos presentes no aquífero que podem biodegradar completamente os etenos clorados para eteno se dará com as análises de amostras de água em laboratório de microbiologia no Canadá (SiREM). Os biomarcadores analisados são o Dhc, vcrA, bvcA e tceA. A análise Dhc permite a identificação de organismos Dehalococcoides $s p$ no aquífero por meio da determinação da ácido ribonucleico $16 \mathrm{~S}$ rRNA. A ausência de Dhc na amostra está associada com a ausência do fenômeno da decloração redutiva anaeróbica dos etenos clorados. Sua quantificação está associada com a decloração biológica completa dos etenos clorados para eteno, porém nem todo Dhc pode converter cloreto de vinila para eteno. A avaliação desta capacidade se dá com as análises de genes vcrA, bvcA e tceA, que desempenham papéis específicos na decloração redutiva, sendo que o tceA converte o TCE e o cisDCE para cloreto de vinila, enquanto o vcrA e o bvcA convertem o cisDCE e o cloreto de vinila em eteno (não tóxico) (SiREM Lab, 2017). A ocorrência de diferentes quantidades e proporções de um gene em relação a outro fornecem indicações para diferentes cenários de remediação e/ou gerenciamento ambiental do aquífero.

\section{Capítulo 4 - Avaliação das Técnicas e Equipamentos Utilizados na Investigação de Aquíferos Fraturados}

Com base na experiência acumulada com as investigações realizadas na região do Jurubatuba e em outros projetos, este item procura realizar uma avaliação das técnicas e equipamentos utilizados para o desenvolvimento de modelos conceituais geológico-estrutural, hidrogeológico e da contaminação, com a intenção de oferecer elementos para a decisão de se utilizar dessas técnicas em outros projetos de investigação desta natureza. 
Os próximos itens descrevem brevemente as técnicas, suas limitações, a disponibilidade de uso no mercado, incluindo a existência de mão de obra especializada, uma avaliação da relação custo-benefício e a indicação das situações recomendadas para o uso.

\section{1 - Desenvolvimento do Modelo Conceitual Geológico-Estrutural}

A experiência na observação de fraturas em afloramentos e sondagens indica que poucas são as fraturas importantes para o fluxo da água subterrânea, sendo mais comum a ocorrência de fraturas fechadas e não transmissivas. Entretanto, as fraturas mais condutivas em rocha fraturada são produzidas por processos geológicos, e a determinação desses processõs é essencial para que a investigação da área contaminada seja bem sucedida.

Os cenários geológicos que geram fraturas condutivas são bastante variáveis. Planos onde ocorrem contrastes de materiais de diferentes competências podem representar os principais controles de fraturas, como um plano de acamamento em rocha sedimentar, ou a foliação num xisto ou gnaisse. Numa rocha granítica maciça, juntas de esfoliação paralelas à superfície podem exercer o controle sobre as fraturas. Em rochas vulcânicas, os planos de derrames e os processos de resfriamento podem gerar as fraturas mais condutivas. Numa rocha submetida a intensa deformação por eventos tectônicos, densas zonas de fraturamentos e falhamentos podem ser criadas. Para a obtenção de interpretações desta natureza, uma série de atividades devem ser realizadas, como as descritas a seguir.

\section{Obtenção de Dados Existentes e Análise de Lineamentos}

A obtenção de dados geológicos existentes de locais próximos da área de interesse ambiental é importante para a composição do modelo conceitual geológico-estrutural. Os dados podem ser provenientes de publicações ou de relatórios existentes, a serem obtidos em diferentes órgãos públicos e privados, e podem conter a localização e descrição de sondagens e poços. As informações podem ser organizadas em um sistema de informações geográficas e produtos podem ser obtidos a partir de então, como mapas de espessura sedimentos, de manto de intemperismo, topo rochoso, potenciométricos e de contaminações em propriedades vizinhas, dentre outras possibilidades. Independentemente da complexidade do projeto, a execução desta etapa é altamente recomendável em todos os casos, pois ela se destina para à definição e planejamento de todos os trabalhos posteriores.

Como indicado no item 2.3.1., as imagens aéreas e de satélite são as principais fontes para a realização da análise de lineamentos, que fornece uma avaliação preliminar das principais 
tendências estruturais da área de interesse ambiental, em especial as zonas de fraturamento de grandes dimensões. O posicionamento de lineamentos próximos à área fonte de contaminação ajuda a orientar as atividades de investigação em escala local, como o posicionamento dos locais para investigações geofísicas de superfície e também para a locação de sondagens. A execução desta tarefa é também altamente recomendável em todos os projetos, mesmos os mais simples.

Tanto nesta atividade, como na de obtenção e tratamento de dados geológicos existentes, é necessário que um profissional com experiência em geologia estrutural e estratigrafia seja responsável pela criação dos produtos. O custo para a realização das tarefas é baixo em relação ao benefício proporcionado pelo planejamento das etapas seguintes.

\section{Caracterização Geológica-Estrutural em Afloramentos}

Como indicado no item 2.3.1., o levantamento geológico-estrutural em afloramentos, em especial com o uso da técnica de scanline, é uma atividade a ser realizada com a finalidade de se identificar os principais grupos de fraturas e os campos de esforços responsáveis pela sua geração, resultando na identificação de quais grupos são probabilisticamente mais favoráveis ao fluxo de água subterrânea. Esta também é uma atividade imprescindível e recomendada em todas as situações, pois é a única em que é possível observar todas as características da arquitetura da rede de fraturas (orientação, densidade, espaçamento, comprimento, terminação, rugosidade, preenchimentos, abertura, feições de fluxo). Algumas feições importantes para o fluxo, entretanto, não podem ser visualizadas em perfurações, como comprimentos e terminações de fraturas, além de estruturas de mergulho paralelo à perfuração. A observação do tipo da rocha é também imprescindível, já que as suas características de intemperismo a partir das fraturas observadas são importantes para definir se os contaminantes podem sofrer difusão na matriz rochosa.

As principais limitações do uso da técnica relacionam-se com a possibilidade de não haver exposições rochosas nas imediações da área de interesse ambiental, situação relativamente comum em áreas urbanas e quando o manto de intemperismo é muito espesso. Outro ponto importante é que as fraturas que ocorrem em rochas próximas da superfície podem não ser estatisticamente representativas daquelas que ocorrem a profundidades de poucas dezenas de metros, especialmente por conta dos efeitos do intemperismo, que podem criar fraturas de padrões diferentes. De qualquer forma, as fraturas próximas da superfície são importantes de 
serem determinadas e consideradas no modelo conceitual, pois a contaminação ocorre a partir da superfície e podem se utilizar das fraturas rasas como via de transporte.

Assim como nas atividades do item anterior, um profissional com experiência em geologia estrutural é necessário para a realização dos levantamentos, assim como um especialista sênior no assunto, para orientar a execução dos trabalhos de campo e na interpretação dos resultados. $\mathrm{O}$ custo para a realização dos levantamentos é baixo em relação ao benefício potencial dos resultados, que também servirão de base para o planejamento das etapas seguintes.

\section{Geofísica de Superficie}

Os métodos geofísicos de superfície tem aplicação útil especialmente em locais próximos de áreas fontes de contaminação, para complementar as informações de estratigrafia e zonas de fraturamento, necessárias para definir a locação de sondagens de investigação (item 2.3.2). São particularmente úteis nas situações em que se identificam lineamentos em imagens próximos da área de interesse. Os métodos de aplicação mais comuns são os eletrorresistivos, em especial o caminhamento elétrico, mas os métodos sísmicos também podem ser úteis.

As principais limitações na utilização das técnicas geofísicas de superfície são operacionais. Invariavelmente, ambientes industriais oferecem condições de espaço inadequadas para a distribuição de eletrodos e outros equipamentos, além de vários tipos de interferências eletromagnéticas. Em muitas situações, dados geológicos prévios obtidos em sondagens locais devem estar disponíveis para orientar na interpretação dos dados geofísicos, o que pode representar uma limitação na utilização do método.

Fornecedores de serviços de geofísica de superfície estão disponíveis no mercado brasileiro, entretanto a interpretação dos dados requer o envolvimento de profissionais sêniores. A relação custo/benefício na aplicação da técnica pode ser muito boa, se os fatores limitantes apontados não estiverem presentes.

\section{Sondagens de Investigação e Recuperação de Testemunhos}

A execução de sondagens de investigação que alcançam o aquífero fraturado é tarefa imprescindível para a definição do modelo conceitual de contaminação da área de interesse

ambiental. É através das sondagens que se determinam a localização as fraturas, seus padrões, suas características hidráulicas, quais são aquelas que transportam massa de contaminante. É 
através das análises químicas em testemunhos que se obtém a informação da massa de contaminantes estocada na matriz da rocha.

A experiência obtida com perfurações na região do Jurubatuba tem sido importante para identificar as dificuldades que ocorrem para a realização de sondagens, especialmente na transição entre o manto de intemperismo mole e a rocha alterada dura (Figura 67). O material mole é perfurado com facilidade pelos trados ocos helicoidais (sistema hollow stem auger), enquanto a rocha gnáissica-pegmatítica dura era facilmente perfurada pelo sistema rotativo com coroas diamantadas e barriletes. A transição da rocha alterada mole para a dura, entretanto, corresponde a uma mistura de materiais de diferentes competências, em que os métodos de perfuração não são adequados. Como exemplo, um veio de quartzo de poucos centímetros de espessura imerso no manto de intemperismo torna impenetrável a perfuração utilizando-se do trado oco; a utilização da sondagem rotativa, que apresenta um sistema de circulação de água para funcionar, perfura o veio de quartzo, mas destrói o testemunho de sondagem, impedindo sua recuperação.

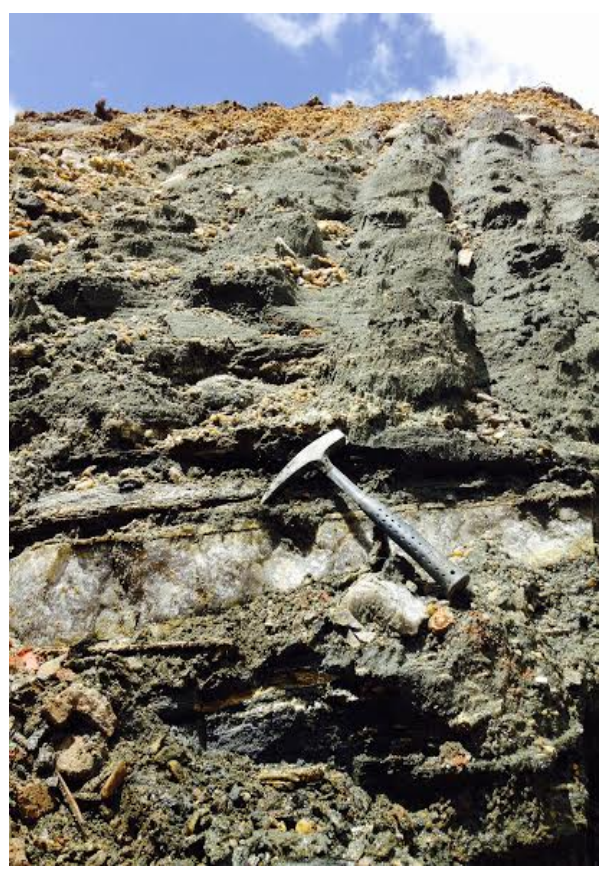

Figura 67 - Veio de quartzo imerso em manto de intemperismo de um xisto do Complexo Embu (Lojkasek-Lima, 2016)

Este problema pode ser considerado crítico em investigações de áreas contaminadas em contexto de manto de intemperismo de aquífero fraturado, pois uma contaminação envolvendo a presença de DNAPL pode não ser detectada nas investigações na situação em que o trado oco não consegue atravessar alguma camada mais resistente possivelmente imersa no manto de intemperismo. Em geral, em circunstâncias como esta, o técnico de campo pode considerar que o topo da rocha sã foi equivocadamente atingido, interrompendo a perfuração. 
Esta situação foi superada no Jurubatuba com a realização de adaptações na ferramenta de perfuração, com a modificação do desenho da coroa de perfuração da sonda rotativa e da disposição dos orifícios de injeção de água utilizada para o resfriamento da ferramenta. Em paralelo, o ritmo da perfuração neste material foi bem mais lento, mas garantiu uma melhor taxa de recuperação dos testemunhos.

O método sônico de perfuração seria o ideal para a perfuração com recuperação de testemunhos em materiais de diferentes durezas. Entretanto, o método não está disponível no Brasil para projetos ambientais. Os equipamentos são de grandes dimensões, muitas vezes não cabem em espaços confinados e os custos de mobilização e operação são atualmente muito elevados e proibitivos.

Outro ponto a ser considerado como importante durante as perfurações relaciona-se com o cuidado na instalação do tubo de revestimento sobre o topo da rocha e ao longo do manto de intemperismo. Quando se perfura numa área suspeita de ocorrer DNAPL em aquífero fraturado, um local propício para a sua acumulação é a base do manto de intemperismo e o topo da rocha dura. A colocação adequada do tubo de revestimento sobre a rocha dura, que promove um bom selo hidráulico e que evita a circulação de líquidos através da base do tubo, é condição fundamental para evitar o espalhamento inadequado da contaminação através das fraturas profundas.

Para futuras investigações envolvendo perfuração neste contexto geológico, é importante que dificuldades na realização da perfuração e na instalação do tubo de revestimento do manto de intemperismo sejam previstas. A execução apropriada da perfuração neste trecho crítico requer um tempo maior, profissionais de campo experientes e empresa de perfuração com estrutura adequada, combinação esta que certamente causa impacto nos custos do projeto.

É importante mencionar que, embora as sondagens sejam as principais fontes de informação sobre a localização de fraturas em profundidade, complementando as informações geológico-estruturais observadas em afloramentos, elas também apresentam suas limitações. Por serem normalmente realizadas na vertical, fraturas de elevado mergulho não são interceptadas pela perfuração, não podendo ser localizadas. Estas poderiam ser visualizadas se as perfurações fossem executadas com inclinação máxima de $60^{\circ}$. Além disso, por conta da perfuração ser uma estrutura de uma dimensão, a distribuição espacial de todas as fraturas em profundidade só poderia ser estimada se ao menos três sondagens inclinadas fossem realizadas. 
Os testemunhos de sondagens recuperados devem ser cuidadosamente descritos em sua geologia e estruturas tão logo sejam retirados das perfurações, tal como apresentado no item 3.2.2., para que rapidamente se definam quais trechos deverão ser amostrados para a realização de análises físicas e químicas. A realização destas análises é imprescindível em projetos de investigação de aquíferos fraturados contaminados, razão pela qual é necessário haver um profissional experiente na realização das tarefas de descrição dos testemunhos e na definição das amostras a serem coletadas.

\section{Perfilagens Geofísicas em Sondagem e Poços Existentes}

As perfilagens geofísicas de paredes de sondagens e poços no aquífero fraturado auxiliam na definição de suas condições construtivas e na identificação da litologia, estratigrafia e estruturas em geral (item 2.4.2). As principais perfilagens utilizadas no Jurubatuba para o aprimoramento do modelo conceitual geológico-estrutural foram os imageamentos acústico e ótico, seguidos das perfilagens de calibre e gama natural, realizados tanto em poços de produção desativados, como na perfuração realizada para a instalação do sistema multinível. A filmagem da perfuração com câmera de visada frontal e lateral é uma atividade desejável de ser realizada antes da execução das perfilagens geofísicas, sendo importante para a identificação prévia de geologia, estruturas e de possíveis problemas estruturais com a perfuração ou poço.

Estas atividades são imprescindíveis de serem executadas em projetos de investigação de contaminação de aquíferos fraturados. Os testemunhos de sondagem sozinhos não possibilitam obter dados geométricos de fraturas na precisão que as perfilagens por imageamento conseguem. Os dados obtidos de todas as perfilagens são melhor organizados e visualizados em softwares como o Wellcad (exemplo na Figura 41).

A situação ideal é que as técnicas de perfilagem geofísica sejam realizadas conjuntamente, e não apenas uma isoladamente, especialmente as perfilagens por imageamento. Isso porque a perfilagem ótica somente funciona no caso da água estar limpa e a parede do poço sem incrustrações. O imageamento acústico funciona nestas condições, mas apenas dentro da água, além de não possibilitar a visualização e a descrição da rocha como ela é. A vantagem do imageamento acústico é que ele possibilita perceber melhor as fraturas ocultas por incrustrações e com alguma abertura, o que não é possível muitas vezes com o imageamento ótico.

A disponibilidade destas ferramentas no Brasil é relativamente pequena, poucas empresas de geofísica prestam este tipo de serviço, mas a tendência é que o mercado se prepare para 
atender o aumento de demanda, embora a aquisição das ferramentas de imageamento represente um investimento razoável. A relação custo-benefício da execução desta atividade é excelente, pois a execução dos serviços é relativamente rápida.

\section{2 - Desenvolvimento do Modelo Conceitual Hidrogeológico}

\section{Avaliação de Fluxo com Flowmeter}

A utilização de flowmeter é altamente recomendada em projetos de investigação de áreas contaminadas em aquíferos fraturados. Isto se deve pois trata-se de um método direto, prático, rápido e eficiente de varredura de perfurações para definição de fraturas condutivas. As perfilagens de fluxo podem ocorrer $(i)$ de forma estática (sem bombeamento), que possibilita identificar fraturas condutivas apenas a partir de diferenças de cargas hidráulicas entre fraturas no poço; (ii) com o poço em bombeamento, o que possibilita identificar as fraturas que efetivamente produzem fluxo e a que taxas; e (iii) em testes tipo cross-borehole, que possibilita o mapeamento de conectividade de fraturas em determinada área quando se bombeia uma perfuração enquanto se realiza a perfilagem em outro (Williams \& Paillet, 2002).

Os testes possibilitam, de forma relativamente simples, a obtenção das propriedades de transmissividade de trechos de interesse do aquífero fraturado; obtém-se também a importante informação de quais fraturas fornecem água para o poço e quais fraturas perdem água do poço, o que orienta nas atividades posteriores de ensaios com obturadores e coleta de amostras de água representativas do aquífero. As avaliações de fluxo com o flowmeter devem ocorrer após a obtenção dos dados de imageamento, quando se definem as melhores fraturas no poço que devem ser testados.

Embora de execução relativamente simples e rápida, o que torna acessível a obtenção do serviço, o equipamento tem disponibilidade limitada a poucas instituições no Brasil. O investimento para aquisição é, assim como os demais equipamentos de perfilagem geofísica, relativamente elevado, embora a aquisição conjunta destes equipamentos de um mesmo fornecedor possa representar vantagens de custo.

\section{Impermeabilização de Sondagens com Liners}

As perfurações executadas em áreas contaminadas de aquíferos fraturados não devem permanecer abertas por muito tempo, pois a perfuração conecta fraturas abertas de diferentes cargas hidráulicas, proporcionando um espalhamento da contaminação para outras fraturas do 
aquífero (item 3.2.4). A lona impermeável (liner) é bastante útil para interromper o fluxo, além de também servir para realização de ensaios hidráulicos e para instalação e um sistema de monitoramento de cargas hidráulicas com transdurotes de pressão. Porém há alguns problemas que representam desvantagens, considerando a realidade brasileira:

(i) há somente um único fabricante e fornecedor do item (FLUTe) e dos acessórios (como o green machine, que viabiliza a retirada da lona do poço, quando necessário) nos Estados Unidos, o que torna o item de elevado custo num projeto;

(ii) o processo de importação encarece o produto e consome grande quantidade de tempo do projeto. Neste caso, qualquer sondagem a ser realizada na rocha só pode ser iniciada se o liner já estiver disponível para utilização;

(iii) a operação do liner e do green machine requer treinamento específico, demandando profissionais altamente qualificados.

(iv) o liner é relativamente frágil e pode se romper em situações de parede de perfuração muito rugosa ou quando o green machine o estica bastante durante sua retirada do poço.

Possivelmente, permanecer com a perfuração aberta seja a situação mais delicada e indesejável durante a execução do projeto de investigação, pelo potencial de agravamento do problema ambiental. Neste sentido, no caso de impossibilidade de utilização de liners, o projeto de investigação precisa ser gerenciado de forma que todas as atividades de perfilagens geofísicas e de fluxo sejam realizadas imediatamente após a execução do furo, seguido da imediata instalação de obturadores infláveis dedicados à perfuração e posicionados de forma a isolar as fraturas mais transmissivas e de maiores diferenças de potencial hidráulico. Os obturadores poderiam ser posteriorment removidos quando da instalação do sistema de monitoramento definitivo.

De toda forma, o desenvolvimento de lonas impermeáveis no mercado nacional teria bastante utilidade para a condução mais confortável de projetos de investigação de aquíferos fraturados.

\section{Perfilagem de Temperatura}

A perfilagem de temperatura (item 3.2.5) resultou na obtenção de dados interessantes para o mapeamento de fraturas hidraulicamente ativas em Jurubatuba. Entretanto, o método apresenta um conjunto de desvantagens que inviabiliza sua utilização no Brasil. A ferramenta foi 
desenvolvida na Universidade de Guelph e é única; a operação e interpretação dos dados requer o trabalho de um profissional extremamente qualificado, hoje o desenvolvedor da ferramenta (Pehme, 2012); e o processo de importação temporária dos equipamentos é uma tarefa exaustiva.

\section{Ensaios Hidráulicos e Coleta de Amostras com Obturadores}

A utilização de obturadores infláveis em projetos de investigação de contaminação de aquíferos fraturados é fundamental. Ela possibilita isolar uma fratura ou conjunto de fraturas para determinar os seus valores de transmissividade com maior exatidão, a medição de cargas hidráulicas relativas (e portanto indicar o potencial de fluxo de uma fratura para outra), e coletar amostras de água mais representativas de profundidades discretas do aquífero fraturado (Figura $51)$.

Os equipamentos necessários para a realização destas atividades não estão ainda disponíveis no mercado brasileiro de forma completa. O CEPAS-USP montou um conjunto de equipamentos (obturadores, guinchos, tripé, transdutores, datalogger, notebook, bombas de vácuo, pressão e submersa, medidores de vazão e conjuntos de cabos e tubos) em um trailer no âmbito do projeto Jurubatuba (Figura 48 e Figura 68).

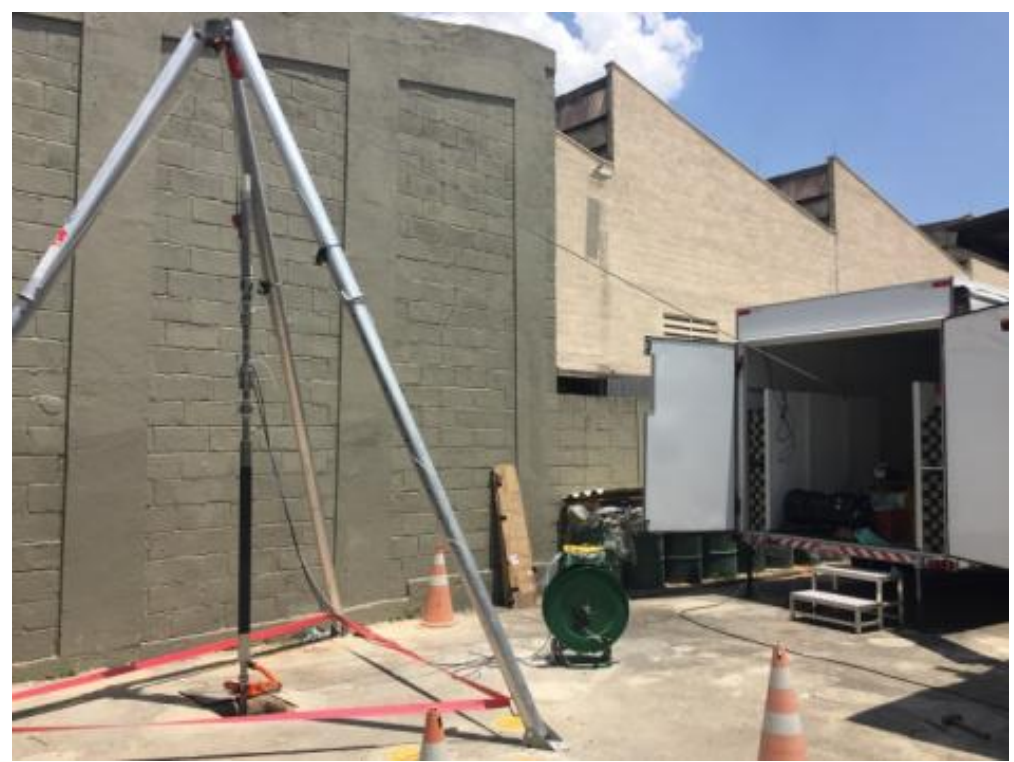

Figura 68 - Obturadores sendo colocados no interior da perfuração MP-01, utilizando-se do laboratório móvel de campo do CEPAS-USP.

A experiência obtida na montagem e operação dos equipamentos mostra que, se por um lado a qualidade dos dados obtidos em campo de propriedades hidráulicas, potenciais hidráulicos e de amostras coletadas é de nível de excelência, por outro lado um grande investimento de 
recursos e de tempo de profissional ultraqualificado devem ser realizados para o projeto, montagem, operação, avaliação, manutenção e melhoria do sistema, o que dificulta a disponibilização plena dos serviços para os projetos de investigação em geral. A construção do sistema pode ser entendida como uma atividade artesanal de engenharia.

Há algumas poucas empresas no mercado, especialmente ligadas ao ramo de construção e manutenção de poços de produção, que fornecem serviços utilizando obturadores. Porém, o trabalho se restringe à retirada de amostras para análises e medições de potenciais hidráulicos de controle limitado. Exemplo desta afirmação pode ser identificado em Fanti et al (2017) (Anexo 2), em que não foi possível a obtenção de cargas hidráulicas abaixo do obturador mais profundo e de dados de transmissividade de fraturas, por conta de limitações do sistema utilizado.

Os trabalhos em andamento no doutorado de Barbosa (2015) em poços profundos do Jurubatuba implicam na realização de três tipos de ensaios hidráulicos por conjunto de fraturas identificadas nas perfilagens, representando um tempo de cerca de duas a três semanas de trabalho em cada poço. Este tempo torna inviável a realização destas atividades em projetos usuais de investigação de áreas contaminadas. Para estes projetos, as perfilagens com flowmeter podem definir três ou quatro profundidades de interesse no poço para, com a utilização de obturadores, realizar a medição de cargas hidráulicas, um ensaio hidráulico rápido tipo slug test e a coleta de amostras d'água num período de tempo mais curto, de forma a tornar a atividade mais econômica. Um sistema de obturadores mais leve, menor e compacto precisa ser desenvolvido para dar a devida agilidade nos trabalhos de campo.

Lembra-se, em tempo, que a definição das profundidades de coleta de amostras d'água deve ser baseado na combinação de trechos com fraturas mais transmissivas e cargas hidráulicas mais elevadas e que contribuem com a entrada de água no poço a partir do aquífero, ou seja, não é adequado coletar amostras de água de uma fratura que drena a água de mistura de várias profundidades no poço.

\section{Ensaios Hidráulicos tipo Cross-Borehole}

Os ensaios hidráulicos tipo cross-borehole permitem a realização de um mapeamento de conectividade de fraturas em determinada área quando se bombeia uma perfuração e se realiza a o monitoramento de cargas hidráulicas em outras (item 2.4.3). A atividade é recomendável de ser realizada especialmente em situações em que se deseja identificar se a contaminação observada em um poço de produção tem origem a partir de uma área fonte de contaminação conhecida. 
Esta atividade está prevista de ser realizada em Jurubatuba no escopo do projeto de doutorado de Pino (2017), em que poços de abastecimento deverão sofrer algum distúrbio de cargas hidráulicas (por bombeamento ou injeção) e as cargas hidráulicas sendo monitoradas no sistema multinível Westbay. O trabalho é bastante demandativo de atenção para a organização das permissões e logística, não sendo viável em muitos casos práticos.

Um ensaio de bombeamento de um poço de produção com o monitoramento de cargas hidráulicas em poço de monitoramento convencional, instalado na base do manto de intemperismo, e em outro poço de monitoramento instalado na rocha, foi realizado no trabalho de Fanti et al (2017) (Anexo 2). O trabalho comprovou a ocorrência de conexão hidráulica entre o poço bombeado e a base do manto de intemperismo.

\section{Sistema Multinível no Manto de Intemperismo}

O monitoramento apropriado de cargas hidráulicas e de qualidade da água subterrânea da base do manto de intemperismo é fundamental em investigações de áreas contaminadas em aquíferos fraturados, dado que é comum a ocorrência de acúmulo de massa de contaminantes na sua base e haver a possibilidade de comunicação hidráulica desta unidade com o aquífero fraturado.

No projeto Jurubatuba, o sistema multinível CMT com sete portas foi testado (item 3.2.9, Figura 56). O sistema teve processo de instalação relativamente rápido e eficiente. Encontra-se em funcionamento e é adequado para a obtenção de valores exatos de cargas hidráulicas. Entretanto, a utilização da bentonita TR 60 Pel-Plug ${ }^{\circledR}$ provocou uma substancial alteração na qualidade da água subterrânea, tornando o poço sem função para este fim. O pellet da bentonita tem um tratamento na superfície à base de matéria orgânica que promoveu uma intensificação do processo de biodegradação dos etenos clorados por decloração redutiva. A utilização desta bentonita se deveu à informação de que sua colocação seria mais precisa, o que evitaria a obstrução de portas de monitoramento, situação conhecida quando se utiliza a bentonita convencional.

O sistema CMT de sete portas também se mostrou de operação mais difícil para a coleta de amostras, implicando em vazões muito pequenas e longo tempo de amostragem. A instalação de dois sistemas de três portas de monitoramento com a utilização de pellets de bentonita convencional talvez possa ser uma solução mais vantajosa em relação ao sistema de sete portas utilizado. De qualquer forma, a utilização do sistema CMT oferece a oportunidade de se executar 
o monitoramento de porções discretas do aquífero, tem disponibilidade no mercado e custo relativamente competitivo, apresentando muitas vantagens em relação à instalação de vários poços de monitoramento convencionais.

\section{Sistema Multinível no AquíferoFraturado}

O sistema multinível Westbay instalado em Jurubatuba possui 16 portas de monitoramento distribuídos entre as profundidades de 16 a $55 \mathrm{~m}$ (item 3.2.10, Figura 62), monitorando de forma discreta todas as principais fraturas transmissivas identificadas no maciço. Trata-se de um sistema extremamente eficiente e confiável, possibilitanto a obtenção de dados de potenciais hidráulicos, a execução de ensaios hidráulicos e obtenção de amostras de água subterrânea com muita qualidade.

A instalação de poços desta natureza é recomendável, entretanto, somente em situações de contaminação complexa, intensa e com vários atores envolvidos. Isto se deve especialmente por conta dos custos elevados e do tempo excessivo que decorre entre a finalização da sondagem e a efetiva instalação do sistema, que no caso do projeto Jurubatuba se estendeu por mais de um ano, devido às condições existentes para a realização de importações definitivas e temporárias. A operação do sistema multinível Westbay requer a obtenção de equipamentos específicos e o trabalho de técnicos de campo especializados e treinados pelo fabricante, o que restringe sobremaneira a sua ampla utilização.

A instalação de um sistema multinível se justifica em todos os casos, pois o monitoramento contínuo do aquífero fraturado contaminado é importante para possibilitar a avaliação da evolução da qualidade da água subterrânea (atenuação natural ou elevação das concentrações), determinar os sinais de entrada e saída de água das fraturas por recarga, descarga natural ou bombeamento e identificar o comportamento hidráulico das fraturas mais condutivas ao longo do tempo. O sistema multinível deve também ser confiável o suficiente para que as fraturas mais condutivas sejam isoladas, evitando a contaminação cruzada entre fraturas através do próprio poço.

Considerando as questões de acessibilidade de sistemas multiníveis como o Westbay, FLUTe ou Waterloo/Solinst, que são os mais modernos atualmente, os poços de monitoramento convencionais, simples ou multiníveis, devem ser considerados como opções em projetos brasileiros, especialmente por conta dos custos menores e disponibilidade de fornecedores. Os poços convencionais são aqueles instalados em perfurações com revestimentos e filtros 
instalados em meio a pré-filtro de areia, sendo as profundidades de interesse isoladas por selos de bentonita. Poços multiníveis de 1,5" com três profundidades de monitoramento podem ser instalados em perfurações de 6". Para efeito da adequada gestão de áreas contaminadas, três profundidades de monitoramento escolhidas com critérios baseados em potenciais hidráulicos, transmissividade e qualidade da água podem ser suficientes e adequados para os objetivos da gestão.

\section{3 - Desenvolvimento do Modelo Conceitual da Contaminação}

\section{Análises Físicas e Químicas em Testemunhos de Sondagem}

A realização de sondagens com a coleta de testemunhos é fundamental em projetos de investigação de contaminação de aquíferos fraturados, especialmente nos trechos de investigação correspondentes à rocha alterada mole e rocha alterada dura (Figura 69), devido à maior possibilidade de acúmulo de massa de contaminantes. Em geral, em regiões tropicais, a passagem do solo residual para a rocha dura é gradual e definida pelo limite de penetração por ensaios SPT (Vaz, 1996). Além disso, matacões, fragmentos de rocha dura e veios de quartzo podem ser encontrados dentro do horizonte de rocha alterada mole (solo residual), dificultando muitas vezes o avanço das perfurações.

Juntamente com a rocha alterada mole, uma massa considerável de contaminantes pode se alojar na porosidade primária da rocha alterada dura, que não é perfurada por sondas de trado oco (Figura 70). Sondas rotativas com coroa diamantada devem ser utilizadas para a recuperação do testemunho neste contexto e análises de porosidade devem ser realizadas, dentre outras. As análises químicas de contaminantes devem também ser realizadas nestes horizontes, pois podem representar uma fonte secundária contínua de contaminação para a água subterrânea se as atividades de remediação ou de contenção física não alcançarem este nível.

À medida que o intemperismo vai diminuindo, especialmente nas rochas graníticasgnáissicas (cristalinas) sãs, a porosidade total vai tendendo a zero, tornando improvável a migração do contaminante na matriz do aquífero e desnecessária a realização das análises físicas e químicas. Entretanto, alguma importância deve ser dada à coleta de amostras para análises físicas e químicas na rocha sã junto à zonas fraturadas. 


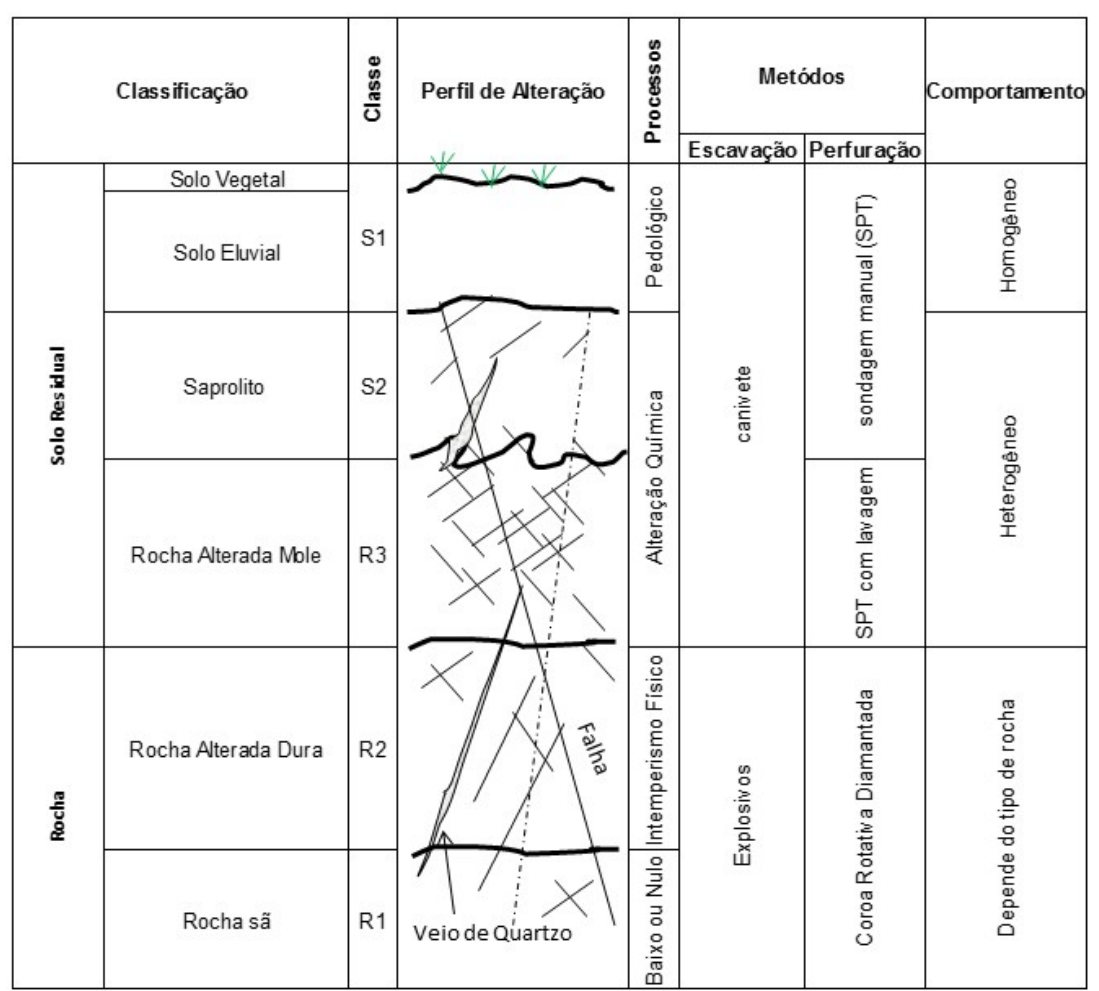

Figura 69 - Classificação de perfis de intemperismo para regiões tropicais (Vaz, 1996)

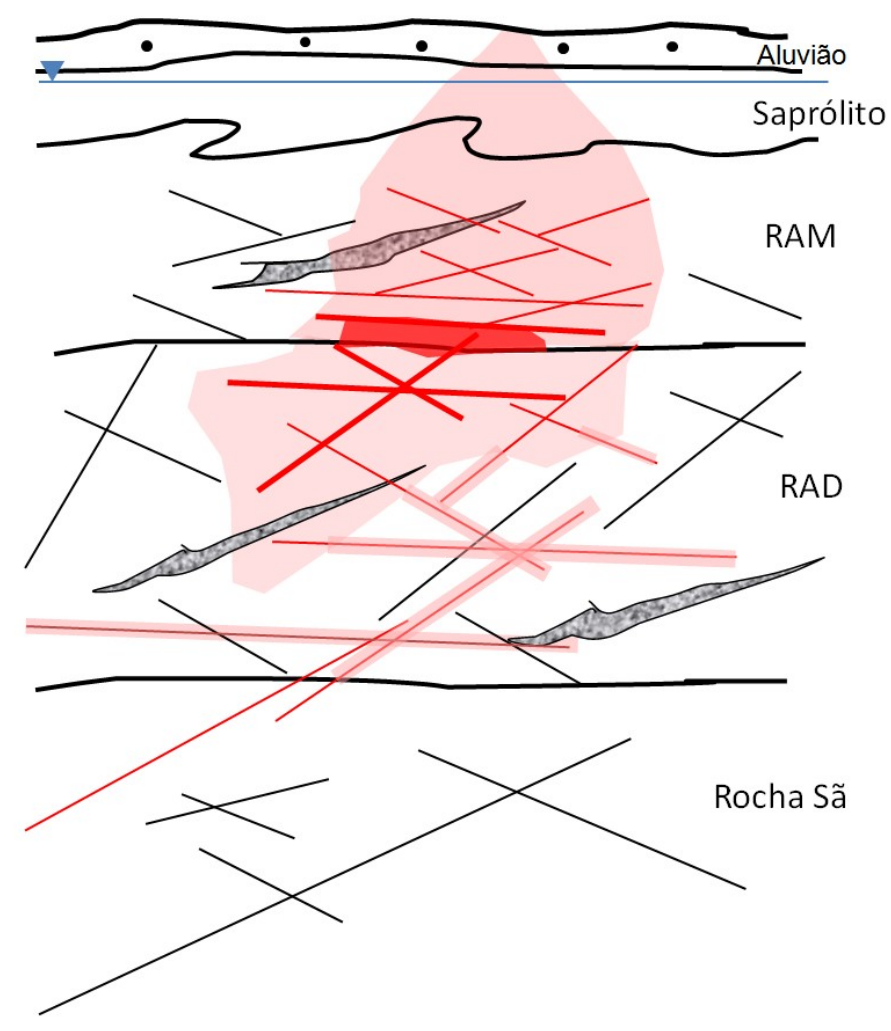

Contaminante disseminado na matriz intergranular

Fase livre ou residual

/ Fratura

Fratura com fase dissolvida

Fratura com fase livre ou residual Halo de difusão para a matriz intergranular a partir da fratura

Veio de quartzo

$\checkmark$ Nível d'água

RAM = Rocha alterada mole

$\mathrm{RAD}=$ Rocha alterada dura

Figura 70 - Possível modelo conceitual de contaminação de solventes organoclorados em manto de intemperismo e aquífero fraturado de rochas graníticas-gnáissicas. 
O número de amostras a serem coletadas para análises químicas sugerido pela metodologia DFN (mínimo de 3 amostras por metro de testemunho) talvez seja elevado e mais apropriado para investigações de natureza científica-acadêmica. Entretanto, é importante salientar que os trechos de mudanças de litologia ou de ocorrência de estruturas são os mais importantes para acúmulo de contaminantes, devendo ser priorizados para amostragem e análises. O método de coleta e preservação da amostra de rocha alterada dura também merece atenção. De forma a diminuir a perda de contaminantes voláteis durante o manuseio da amostra, a metodologia descrita no item 3.2.2 deve ser considerada, com a utilização de um triturador de rocha, seguida da preservação da amostra em vials com metanol.

A aplicação da metodologia de coleta e preparação de amostras para análises físicas e químicas requer o trabalho de um profissional de campo devidamente treinado, mas as atividades são acessíveis e de baixo custo para a sua realização.

\section{Análises Químicas de Água Subterrânea}

Tal como em qualquer projeto de investigação de áreas contaminadas, a produção de análises químicas de água subterrânea proveniente dos sistemas de monitoramento do manto de intemperismo e do aquífero fraturado é essencial para a avaliação do transporte e o destino dos contaminantes de interesse. No caso dos solventes organoclorados, além da varredura habitual de compostos orgânicos voláteis que incluem todos os etanos, etenos e metanos clorados, o programa de amostragem deve também considerar a coleta de amostras para a avaliação da degradação dos contaminantes, sendo necessária a obtenção das concentrações dos parâmetros envolvidos em reações redox (nitrato, amônio, ferro, manganês, sulfato, sulfeto), parâmetros de campo ( $\mathrm{pH}$, potencial redox, temperatura, condutividade elétrica), gases (metano, eteno, etano), carbono orgânico dissolvido, alcalinidade e, muitas vezes, cátions e ânions maiores.

\section{Análises Isotópicas de Água Subterrânea}

Além de serem utilizados para a avaliação da procedência da contaminação, as análises isotópicas de água subterrânea tem aplicação de grande importância para a avaliação dos processos de degradação dos compostos orgânicos. Assim, a realização de análises de isótopos de carbono e cloro pode oferecer informações importantes e interessantes sobre a possibilidade de ocorrência ou não de decloração redutiva ou de degradação abiótica. Complementarmente, análises de isótopos de hidrogênio e oxigênio também são interessantes para mapear fácies 
hidroquímicas relacionadas com diferentes eventos de recarga ou origens. Estas análises estão sendo realizadas no âmbito do projeto Jurubatuba e os dados serão brevemente disponibilizados. Entretanto, a literatura é farta em descrever a utilidade do método para o desenvolvimento do modelo conceitual da contaminação (Hunkeler et al., 1999; Sherwood et al., 2001; Chatrand et al., 2005; Lojkasek-Lima, 2012; Camillo, 2013). As análises de isótopos de carbono e cloro são realizadas no exterior, mas são acessíveis e apresentam uma ótima relação custo/benefício.

\section{Análises Moleculares e de Microcosmos em Água Subterrânea}

Assim como as análises isotópicas, as análises moleculares e de microcosmos são importantes para a avaliação de ocorrência de degradação microbiana ou abiótica dos contaminantes, suas taxas e tipos de microrganismos que participam do processo (item 3.2.14). Estas análises são particularmente importantes no momento de se avaliar as alternativas de remediação e para a definição de quais parâmetros podem ser alterados para promover a aceleração da biodegradação dos contaminantes por biorremediação.

As tarefas ainda estão em andamento no projeto Jurubatuba, entretanto é possível afirmar que as análises moleculares são acessíveis, embora seja executada em laboratórios no exterior, de custos relativamente baixos e apresentam resultados relevantes para a definição mais detalhada dos processos microbiológicos da biodegradação. Já os experimentos de microcosmos exibem muitas variáveis que interferem na execução dos experimentos, que não são padronizados, exigem a utilização de mão de obra especializada e tempo de execução de longo prazo.

\section{Capítulo 5 - Reflexões sobre a Gestão de Áreas Contaminadas em Aquíferos Fraturados}

Como indicado no Capítulo 1, sabe-se que atualmente as investigações de contaminação em contexto de aquíferos fraturados se restringem às porções mais rasas e de porosidade primária do aquífero, atingindo no máximo o topo da rocha alterada dura no manto de intemperismo. Alguma informação relacionada ao aquífero fraturado profundo é obtida quando se sabe da existência de algum poço de abastecimento profundo próximo que apresentou água com contaminante. Ainda assim, as informações obtidas são de qualidade limitada, pois trata-se de uma amostra coletada na boca do poço, representando uma mistura de várias profundidades e com a bomba submersa que promove perda de massa de contaminante dissolvido. 
Considerando as informações e experiências apresentadas nos itens anteriores e o caso prático relatado no artigo Fanti et al. (2017) (Anexo 2), reflexões sobre alguns aspectos da gestão de áreas contaminadas em aquífero fraturado por fontes individuais são apresentadas a seguir. Em seguida, outras reflexões, baseadas na experiência obtida com o projeto Jurubatuba, são realizadas sobre o gerenciamento de áreas ainda mais complexas, quando múltiplas fontes contaminação ocorrem numa mesma área.

\section{1 - Gestão de Áreas Contaminadas por Fontes Individuais}

\subsection{1 - Escopo de Investigação e Ações de Intervenção}

Os procedimentos visando o gerenciamento de áreas contaminadas descritos na Decisão de Diretoria DD38/2017 da CETESB (2017) são adequados para o gerenciamento de fontes individuais de contaminação, dado que o processo da gestão é facilitado quando se define um único responsável legal pela contaminação, não havendo dúvidas sobre quem deve se ocupar das tarefas de caracterização e reabilitação da área contaminada. Em complementação, este item contribui com algumas recomendações, orientações e insights sobre a condução das tarefas de investigação detalhada e estratégias de implementação de medidas de remediação, contenção e de controle institucional em casos de contaminação de aquíferos fraturados.

A DD38/2017 apresenta a seguinte redação, no que se refere à orientação para a Investigação Detalhada: "A etapa de Investigação Detalhada tem como objetivo caracterizar o meio físico onde se insere a Área Contaminada sob Investigação (ACI), determinar as concentrações das substâncias químicas de interesse nos diversos meios avaliados, definir tridimensionalmente os limites das plumas de contaminação, quantificar as massas das substâncias químicas de interesse, considerando as diferentes fases em que se encontram, caracterizar o transporte das substâncias químicas de interesse nas diferentes unidades hidroestratigráficas e sua evolução no tempo e caracterizar os cenários de exposição necessários à realização da etapa de Avaliação de Risco.”

Considerando que o modelo conceitual de contaminação descrito na Figura 70 é reproduzível para várias situações de aquífero fraturado em regiões tropicais do Brasil, conclui-se pela necessidade de se responder às demandas descritas na DD38/2017 para os diferentes materiais geológicos do aquífero fraturado, incluindo também a rocha alterada dura, que apresenta porosidade primária e pode ser um reservatório importante de massa de contaminantes. 
Qualquer atividade de remediação que não leve em consideração a massa existente nas porções mais duras do aquífero fraturado poderá não apresentar resultados finais satisfatórios, o que resultaria em desperdício de recursos.

Tomando-se como exemplo e ponto de partida a existência de uma Investigação Confirmatória indicando a presença de solventes organoclorados no contexto do saprólito raso, as atividades de Investigação Detalhada podem ser executadas posteriormente em etapas.

- Etapa 1 - Investigação do Manto de Intemperismo

Na primeira, as investigações para a delimitação da contaminação ocorrem até o topo da Rocha Alterada Dura, utilizando-se de técnicas de perfuração a percussão ou rotativa com trado oco com amostragem de solo e água, objetivando quantificar a contaminação na porção rasa (todo o perfil até a base da Rocha Alterada Mole) (Figura 71). Técnicas de investigação de alta resolução podem ser utilizadas nesta etapa, porém com a probabilidade de não se obter sucesso, por impenetrabilidade da ferramenta a percussão. Atenção especial nesta etapa deve ser dada à possibilidade das perfurações não atingirem de fato o topo da rocha dura, mas algum veio ou porções rochosas mais duras, imersos no interior do manto de intemperismo mole. Observações de campo e interpretação da geologia de perfurações vizinhas são fundamentais para se decidir pela interrupção da perfuração. Desta forma, em paralelo a esta etapa de investigação, o levantamento de lineamentos em imagens aéreas e o geológico-estrutural de afloramentos (itens 2.3.1 e 4.1-1 a 4.1-3) é importante de ser realizado. Igualmente, sugere-se a obtenção de análises de amostras brutas de água do poços de abastecimento profundos cadastrados na região (outorgados e também os ilegais), caso ainda não estejam disponíveis. Um ou mais sistemas multiníveis podem ser instalados no manto de intemperismo nesta etapa.

Os resultados desta etapa são decisivos para definir a necessidade de se continuar as investigações posteriores na rocha alterada dura e rocha sã. Caso se observe diminuições nas concentrações com a profundidade ao longo das perfurações, ou mesmo a não detecção de contaminantes na base da rocha alterada mole, então é provável que a contaminação não adentrou nas porções mais profundas do aquífero fraturado, isentando da necessidade de se proceder investigações neste meio. A não detecção de concentrações na água do poço de abastecimento profundo vizinho faria corroborar com a decisão. De outra forma, a detecção de contaminação no poço profundo faria suspeitar da existência de alguma outra fonte de contaminação nas proximidades. 


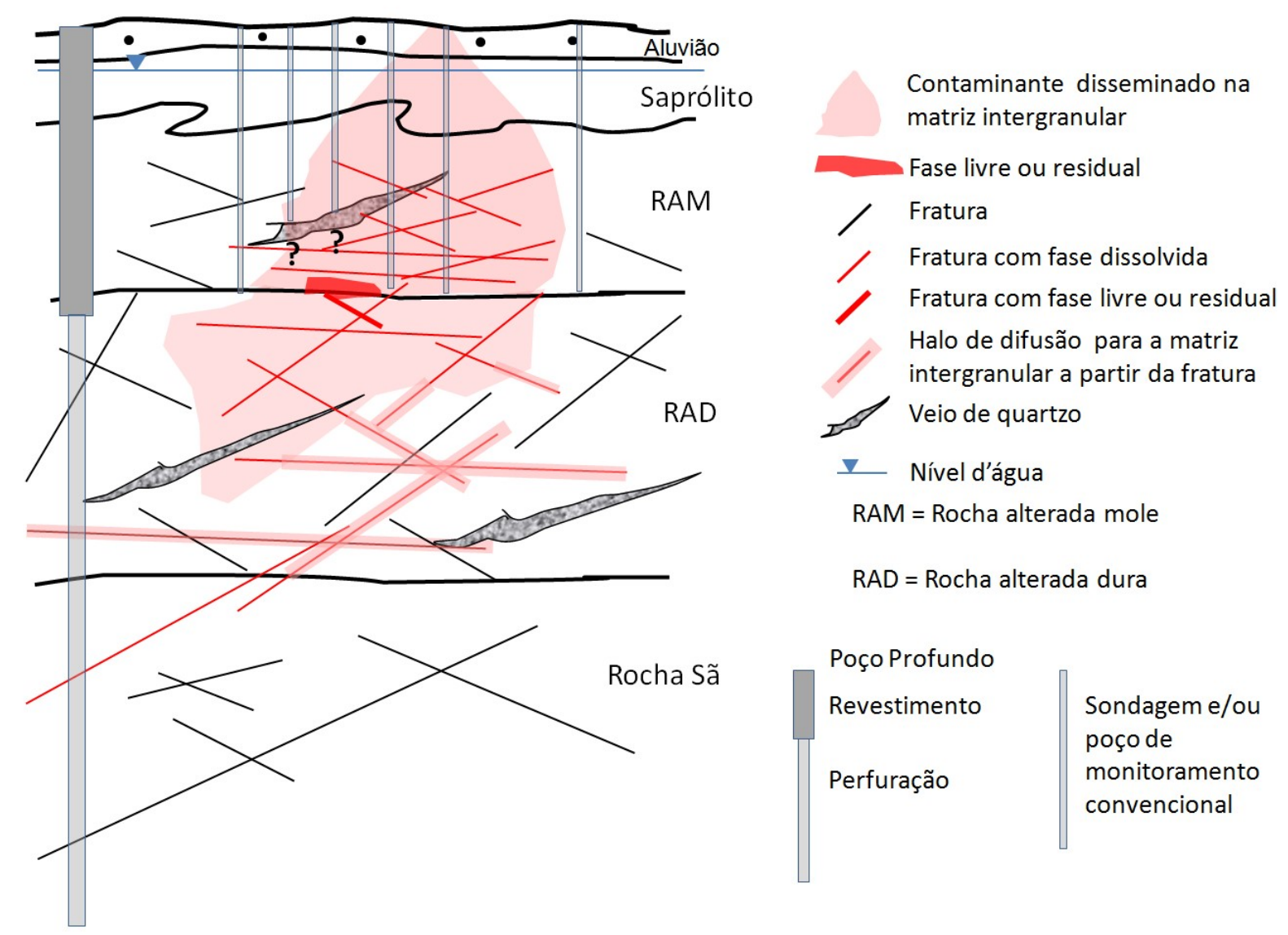

Figura 71 - Etapa 1 de investigação de área contaminada em aquífero fraturado: manto de intemperismo.

- Etapa 2-Planejamento da Perfuração na Rocha

Com a confirmação da necessidade de se continuar com as investigações na rocha, algumas atividades de campo pré-perfuração podem ser realizadas para auxiliar no processo de planejamento da execução das perfurações na rocha dura, especialmente para responder às perguntas: Quantas perfurações são necessárias? Em quais localizações? Até que profundidades? Onde e como tomar amostras de rocha para análises?

Dentre as atividades de campo estão a possível execução de geofísica de superfície em áreas próximas da contaminação e a execução de perfilagens (itens 2.3.2 e 4.1-3) e coleta de amostras discretas em poços de abastecimento profundos contaminados (itens 2.4.2 e 4.1-5). As atividades de geofísica de superfície, como o caminhamento elétrico, podem ser úteis para refinar o modelo conceitual geológico e localizar zonas mais ou menos espessas de manto de intemperismo, ou mesmo a presença de matacões e zonas de fraturamento que não foram identificadas com as sondagens da $1^{\text {a }}$ etapa. A situação ideal é procurar definir a locação das 
novas perfurações onde há uma maior probabilidade de haver fraturamento na rocha.

As perfilagens dos poços de abastecimento profundos representam uma boa fonte de informações que auxiliam na tarefa de locação e definição de profundidades da nova perfuração. Em poços profundos limpos com água transparente, a filmagem e a perfilagem ótica podem servir como referência para a definição da litologia e estruturas. A perfilagem gama natural pode auxiliar na definição de zonas com minerais intemperizados, potenciais sinalizadores indiretos de existência de zonas de maior porosidade primária na rocha dura. O flowmeter fornecerá informações sobre potenciais de fluxo e posição de fraturas mais transmissivas. O uso de obturadores nesses poços proporcionará a coleta de amostras de água de fraturas discretas, fornecendo dados de profundidade da contaminação. Dependendo dos resultados, os poços de abastecimento podem ser transformados em poços de monitoramento multiníveis, com filtros posicionados nas fraturas de maior interesse. Isso faria evitar o agravamento da contaminação cruzada de fraturas de diferentes profundidades promovida pelo próprio poço.

Talvez trêz seja um número mínimo de sondagens que alcancem a rocha sã, distribuídos em área triangular, de forma que as estruturas rúpteis e rochas observadas possam ser posteriormente correlacionadas em perfis, porém em locais dentro da pluma de contaminação do manto de intemperismo e próximos da área fonte, mas evitando-se a própria área fonte onde pode haver DNAPL. O número e o posicionamento das sondagens devem ser definidos caso a caso em função de algumas variáveis, como: (i) tamanho da pluma de contaminação; (ii) geometria do topo da rocha definido na geofísica de superfície; (iii) existência de lineamentos definidos em imagens aéreas; (iv) direção e mergulho de fraturas reconhecidas como abertas, identificadas em afloramentos; (v) existência de receptores, como poços de abastecimento profundos e áreas de descarga de aquífero (rios). A Figura 72 exemplifica a situação em planta.

Uma vez definida a locação e o projeto construtivo das novas perfurações (diâmetros de perfuração no manto de intemperismo e na rocha, posicionamento esperado do revestimento, tempo para cura do cimento do tubo de revestimento, profundidade esperada na rocha, critérios para tomada de amostras de rocha, cuidados para identificar DNAPL durante a perfuração), é importante lembrar que elas devem ser imediatamente seladas após suas execuções, de forma a evitar que a própria perfuração sirva de caminho para a contaminação de fraturas de diferentes profundidades. O tempo para a importação de lonas impermeáveis (liners) ou mesmo a obtenção de um número adequado de obturadores dedicados para este fim deve ser considerado no projeto, e os equipamentos disponíveis para utilização antes da execução das sondagens. 


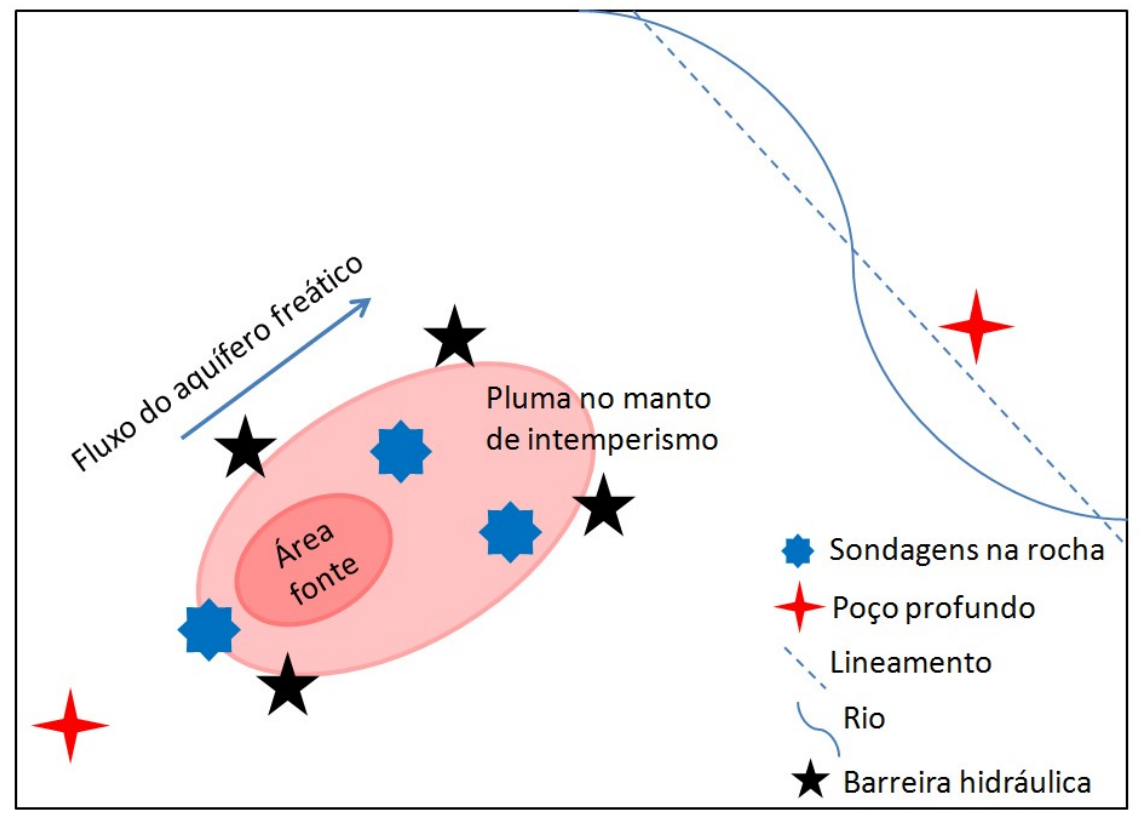

Figura 72 - Ilustração das possíveis locações de sondagens na rocha, considerando os resultados prévios da caracterização geológica, perfilagens de poços e situação da pluma de contaminação do aquífero raso.

\section{- Etapa 3 - Investigação na Rocha Dura}

As atividades e cuidados descritos nos itens 2.4, 4.1 e 4.2 devem fazer parte das investigações geológicas-estruturais, hidráulicas e de distribuição da contaminação na rocha dura. Nesta etapa, executam-se as perfurações com recuperação de testemunhos e se descrevem as características geológicas-estruturais e se definem as amostras para análises físicas e químicas. O objetivo é identificar a distribuição da contaminação na matriz da rocha dura alterada a partir das fraturas, nas mudanças de litologias, e mesmo na possível existência de algum material de manto de intemperismo imerso em meio ao maciço rochoso.

Imediatamente após a conclusão das perfurações, realizam-se as perfilagens geofísicas (gama e ótico e/ou acústico) e de flowmeter (com e sem bombeamento) e definem-se as fraturas mais transmissivas para a execução de ensaios hidráulicos rápidos (slug tests) e amostragens com obturadores. Todas estas atividades devem ser planejadas e realizadas em poucos dias após a conclusão das sondagens, para evitar ao máximo a possibilidade de espalhamento das contaminações através da nova sondagem. Caso isso não seja possível, os liners ou obturadores devem ser utilizados para isolar as fraturas entre uma tarefa e outra. 
- Etapa 4-Projeto e Instalação de Sistemas Multiniveis

Os liners ou obturadores permanecem instalados na perfuração até o momento que o sistema de monitoramento multinível esteja pronto para ser instalado em campo. O objetivo dos sistemas multiníveis é o de realizar o monitoramento da qualidade da água das mais importantes fraturas da rocha dura alterada e da rocha sã durante o período que a área contaminada estiver passando pelo processo de reabilitação (Figura 73).

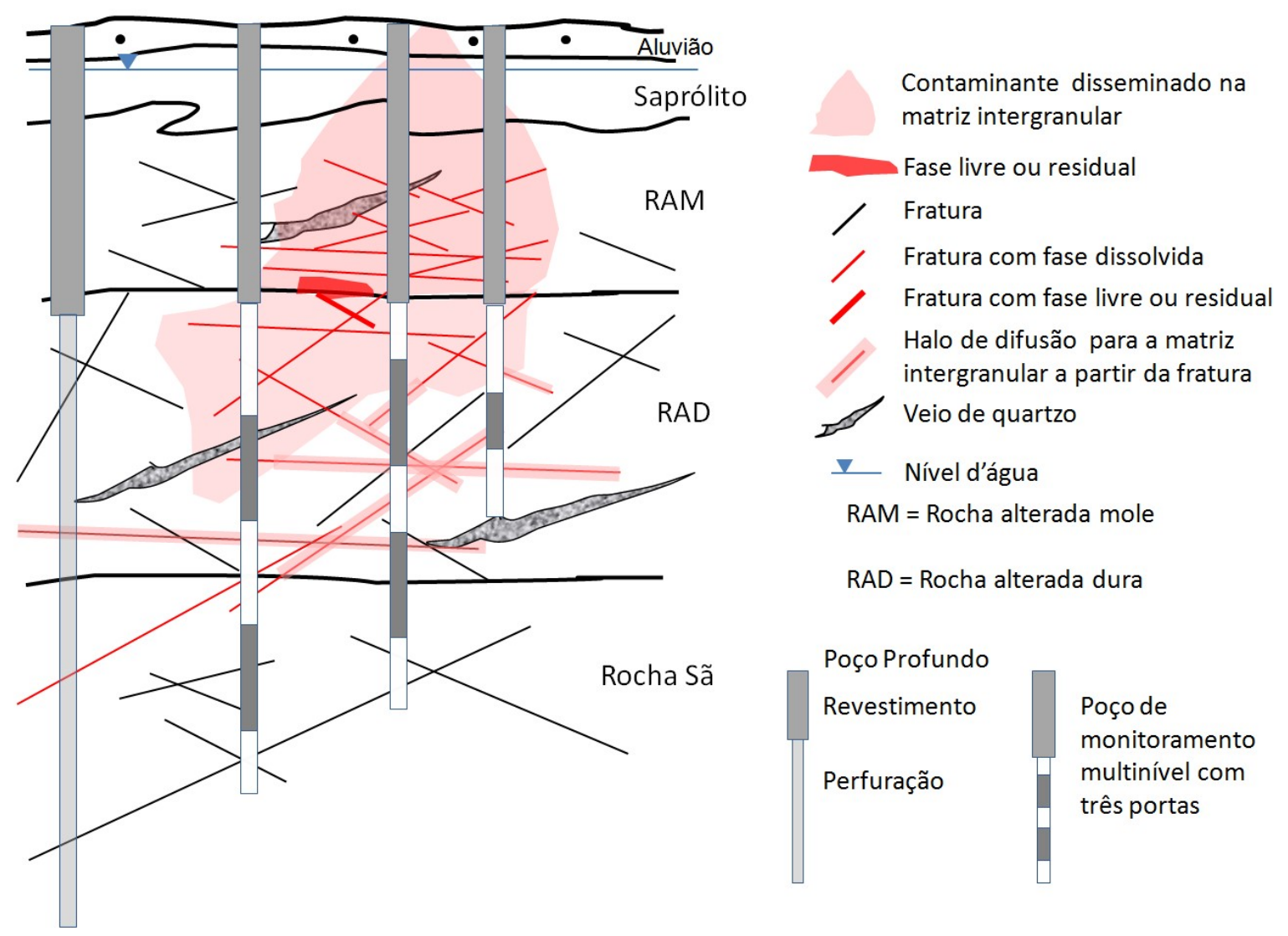

Figura 73 - Etapa 4:instalação de sistemas multiníveis nas sondagens de investigação.

Os tipos de sistemas multiníveis a serem instalados podem ser aqueles mais sofisticados, como o Westbay ou FLUTe, ou poços convencionais. A ideia é procurar monitorar as cargas hidráulicas e a qualidade da água subterrânea em fraturas dentro da rocha alterada dura e na rocha sã da forma mais discreta possível. As vantagens e desvantagens sobre a escolha do tipo de sistema de monitoramento são discutids no item 4.2-12. 


\section{- Etapa 5 - Ações de Intervenção}

As medidas de intervenção possíveis são específicas e suas aplicações dependem das características de cada caso. Não raro, medidas de remediação, de contenção hidráulica, de obras de engenharia e ações institucionais, seguida de um período de monitoramento para encerramento, são realizadas de forma conjunta dentro de um mesmo plano de intervenção. $\mathrm{O}$ exercício descrito a seguir e representado na Figura 74 reflete apenas uma possibilidade de abordagem, mas considera algumas das características gerais que se observa em aquíferos fraturados de rochas graníticas-gnáissicas com espesso manto de intemperismo.

Espera-se que remediação funcione melhor na porção intergranular do aquífero, ou seja, no saprólito e a rocha alterada mole, regiões estas de maior porosidade e permeabilidade relativas. As técnicas de remediação possíveis de serem aplicadas são variadas (destruição química por reações redox, biorremediação, remediação termal, dentre outras) e dependem de um estudo de alternativas de remediação, que irá definir a melhor relação custo, aplicabilidade, tempo necessário.

A porção da rocha alterada dura pode representar um grande desafio para a remediação, pois espera-se que seja um meio de porosidade dupla e de elevada permeabilidade nas fraturas, mas de baixa permeabilidade no maciço. Prevê-se que este seja um meio, portanto, de estocagem de massa de contaminantes e de lento processo de difusão reversa (back diffusion), da matriz para as fraturas, caso alguma ação de remediação seja executada. As medidas de remediação ativa a serem aplicadas na porção mais rasa podem não funcionar ou não serem viáveis na rocha alterada dura, dada as condições de porosidade, permeabilidade e maior profundidade. Testes envolvendo a viabilidade de execução das diferentes técnicas de remediação devem ser realizadas no aquífero da rocha alterada dura, entretanto.

Possivelmente, uma ação viável de ser aplicada neste contexto seja a de se realizar uma barreira hidráulica junto à pluma da rocha alterada dura (Figura 72 e Figura 74), que objetive evitar que a massa de contaminantes saia da região próxima da área fonte e se espalhe por distâncias mais longas no aquífero fraturado. É uma ação que ajuda na remoção de massa de contaminantes, mas que serve especialmente para controlar a pluma próxima à fonte e proteger receptores, embora tal ação possa representar um longo tempo de funcionamento do sistema de bombeamento e tratamento. O monitoramento da atenuação deve ser executado, desta forma, enquanto o sistema de contenção se encontre em operação. 
$\mathrm{Na}$ instalação dos poços de bombeamento da barreira hidráulica, as sondagens executadas devem ser perfiladas e ensaiadas para a definição das estruturas mais transmissivas. Ensaios hidráulicos tipo cross-borehole podem ser executados com o monitoramento dos sistemas multiníveis, de tal forma que se possa avaliar mais precisamente a eficácia do controle hidráulico e a necessidade eventual de se instalar mais algum poço de bombeamento. A depender da densidade e qualidade das informações levantadas, a caracterização da heterogeneidade e anisotropia do aquífero pode resultar na viabilização de realização de modelação matemática do aquífero, com as vantagens de realização de prognósticos de funcionamento do sistema.
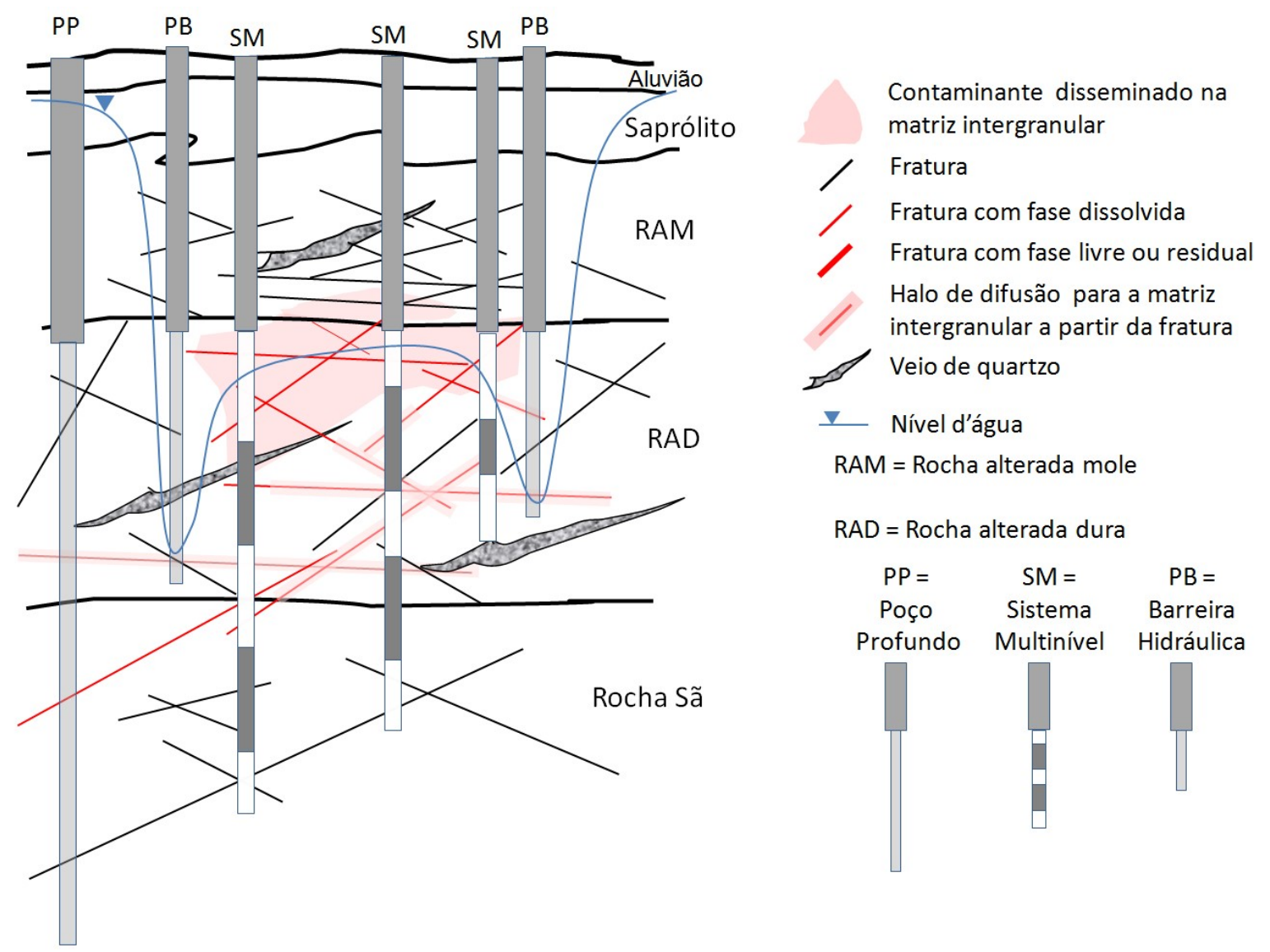
RAD $=$ Rocha alterada dura
$\mathrm{PP}=\quad \mathrm{SM}=\quad \mathrm{PB}=$
Poço Sistema Barreira
Profundo Multinível Hidráulica

Figura 74 - Possível configuração da contaminação após a adoção de ações de remediação na rocha alterada mole e de contenção hidráulica na rocha alterada dura.

As ações no aquífero fraturado da rocha sã resumem-se à adoção de medidas institucionais que visam à proteção de receptores, enquanto as metas de remediação baseadas em risco não são atingidas na região da pluma. Dentre as medidas, estão a interrupção de bombeamento de poços contaminados, a transformação destes em poços de monitoramento e o monitoramento periódico de poços de abastecimento da vizinhança que não foram atigidos pela contaminação. 


\subsection{2 - Exemplo de investigação em aquífero fraturado}

Uma investigação de contaminação em aquífero fraturado realizada pela empresa de consultoria ambiental Waterloo Brasil, no âmbito do mestrado de Aline Fanti e com os resultados publicados na revista Journal of Water Resource and Protection (Fanti et al, 2017 - Anexo 2), serve como referência de atividades de investigação que podem ser realizadas nesses casos.

O trabalho objetivou apresentar os resultados de uma investigação de aquífero fraturado contaminado em que se utilizou de algumas das técnicas e ferramentas descritas anteriormente e que propiciaram o desenvolvimento de um modelo conceitual hidrogeológico mais significativo da área de estudo. Duas perfurações em rocha foram realizadas, onde perfilagens geofísicas (gama, calibre e imageamento acústico) foram aplicadas para a caracterização geológicaestrutural do aquífero. Ferramentas de medição de fluxo natural e obturadores foram utilizadas para obtenção de dados de potenciais hidráulicos e fluxos e para a coleta de amostras de água discretas para análises. Este escopo de trabalho foi executado após a execução de um levantamento geológico-estrutural de afloramentos, da execução de geofísica de superfície e das investigações para delimitação das plumas no aquífero do manto de intemperismo. Os resultados destas atividades não foram apresentados no artigo.

Como resultados, foram identificadas duas espécies de rochas gnáissicas abaixo do manto de intemperismo, uma com predomínio de bandas máficas, mais alterada e com maior densidade de fraturas até $65 \mathrm{~m}$, e outra abaixo, com predomínio de bandas félsicas (Figura 75). Foram definidos 7 grupos de fraturas, sendo aquelas do Grupo 1, de baixo ângulo de mergulho, as mais frequentes e importantes para o fluxo nas rochas até $65 \mathrm{~m}$, e do Grupo 2 (N a NE-SW com mergulhos elevados para $\mathrm{W}$ a NW) mais frequentes nos gnaisses félsicos profundos. Potenciais hidráulicos descendentes foram identificados até $65 \mathrm{~m}$ e ascendentes da base até $65 \mathrm{~m}$. Um ensaio hidráulico proporcionou identificar a ocorrência de conexão hidráulica entre manto de intemperismo com o aquífero fraturado subjacente.

Os resultados obtidos com o modelo conceitual expandido à rocha fraturada são importantes para a tomada de decisões de gerenciamento. Dentre as atividades realizadas que merecem destaque pela qualidade estão o estudo geológico-estrutural realizado a partir dos imageamento das sondagens, a medição de potenciais hidráulicos com os obturadores e a definição do desenho dos poços de monitoramento da rocha com base na identificação dos potenciais hidráulicos e detecção dos compostos organoclorados em amostras obtidas com os obturadores. 


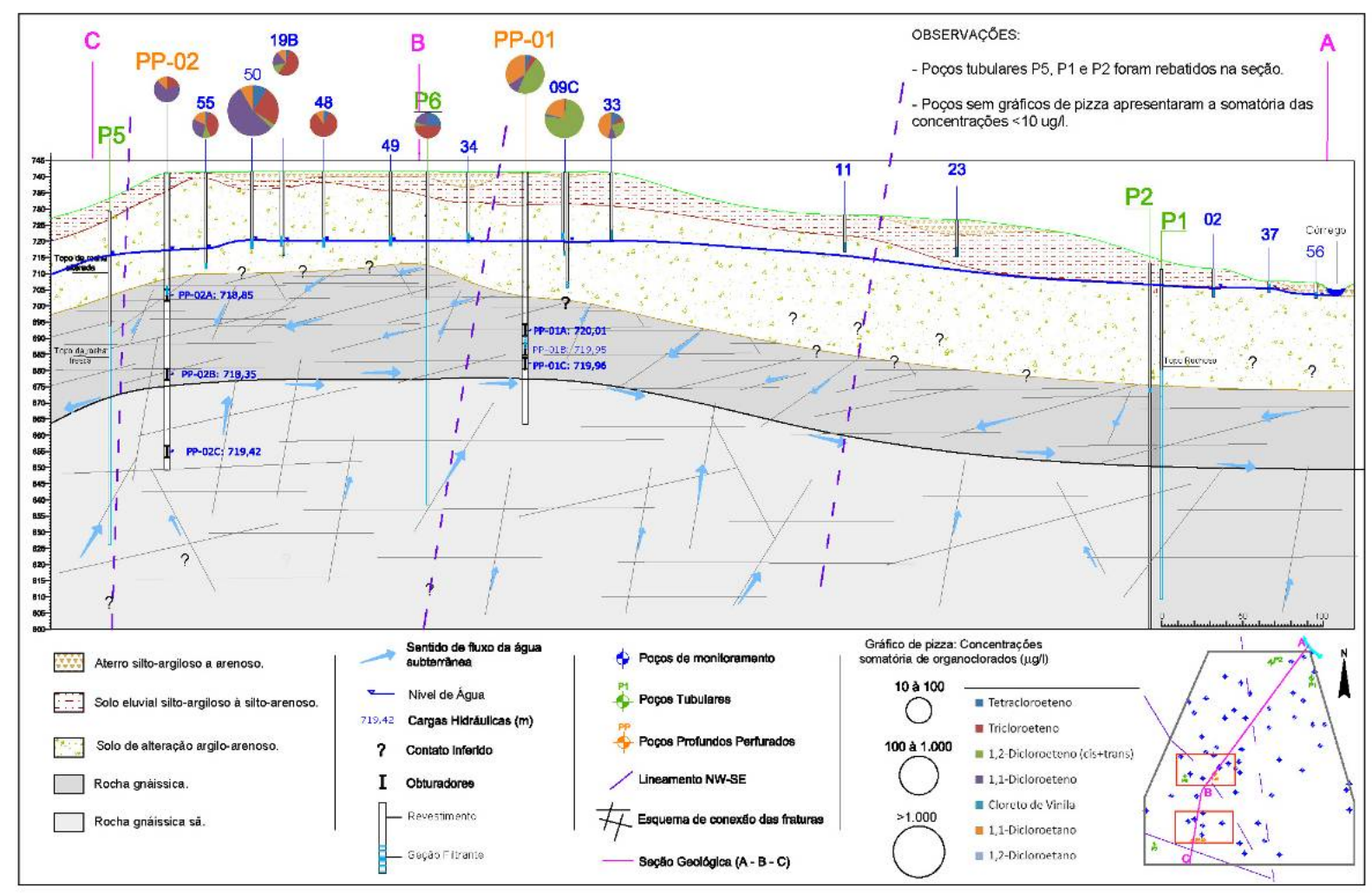

Figura 75 - Síntese do modelo conceitual de contaminação da área de interesse descrito em Fanti et al (2017)

Dentre as limitações que as atividades realizadas proporcionaram ao modelo conceitual, destaca-se o método de perfuração utilizado, que foi um rotopercussivo, que se por um lado é de rápida execução e de baixo custo, por outro impede a coleta de testemunhos de sondagem, impossibilitanto a caracterização geológica e da contaminação na rocha. Outro ponto de limitação foi a opção dos responsáveis pela instalação de poços de monitoramento simples em apenas uma profundidade por perfuração realizada, o que impossibilita o monitoramento de potenciais hidráulicos e de qualidade da água em profundidades diferentes do maciço fraturado.

\section{2- Gestão de Áreas Contaminadas por Fontes Multipontuais}

\subsubsection{Fontes Multipontuais de Compostos Organoclorados na RMSP}

Áreas contaminadas por fontes multipontuais de contaminação podem ser entendidas como aquelas onde ocorrem duas ou mais fontes de contaminação próximas que resultam na ocorrência de superposição de plumas de contaminação, seja em porções rasas ou profundas do aquífero, 
dificultando a definição dos responsáveis legais e da forma de condução da gestão do problema ambiental.

Quando as fontes de contaminação multipontuais se referem aos compostos organoclorados, suas características de maior potencial de espalhamento das substâncias, de maior toxicidade e de mecanismos mais complexos de degradação potencializam ainda mais a intensidade do problema ambiental. Esta combinação pode gerar potencial de existência de novas áreas classificadas como "críticas” pelo Poder Público. A região de Jurubatuba se enquadra numa dessas áreas críticas, com o agravante de que a contaminação por solventes organoclorados por fontes multipontuais atingiu a unidade aquífera fraturada, elevando ainda mais complexidade do problema.

A Figura 3 exibe a localização de áreas contaminadas por solventes organoclorados e que coincidem, grosso modo, com as áreas industriais (em laranja e vermelho) apresentadas na Figura 1. A Figura 76 apresenta a localização de áreas com circunferências de 500 metros de raio ao redor das áreas contaminadas por solventes organoclorados, representando locais que podem sofrer restrição do uso da água subterrânea devido à existência de uma área contaminada (São Paulo, 2006). A superposição de áreas na forma de grupos (clusters) de áreas contaminadas exibem maior probabilidade de serem classificadas como fontes multipontuais. Somente com base na localização das áreas contaminadas existentes, 12 clusters foram reconhecidos (Consentino, 2017), excetuando-se a região do Jurubatuba, que já é classificada como crítica.

A Figura 76 também exibe a localização de poços de abastecimento profundos outorgados pelo DAEE, sendo que várias centenas desses se encontram localizados dentro de alguma área de 500 metros de raio. No trabalho de Consentino (2017), em conjunto com as Vigilâncias Sanitárias municipais, a água de 19 poços profundos foram amostradas em algumas dessas áreas de clusters, tendo sido identificada a contaminação por compostos organoclorados em três deles, sendo todos os poços com uso declarado de água para consumo humano (ingestão). O potencial de número de poços contaminados por compostos organoclorados deve ser maior, em especial nas áreas de clusters de áreas contaminadas. Todas estas áreas com fontes multipontuais, portanto, podem ser identificadas como áreas críticas de contaminação de aquíferos em potencial, por haver vários receptores usuários de água subterrânea ao redor, situação similar à da região do Jurubatuba. Além do iminente risco à saúde de usuários, há um expressivos potencial para ocorrência de danos econômicos em todas essas áreas. 


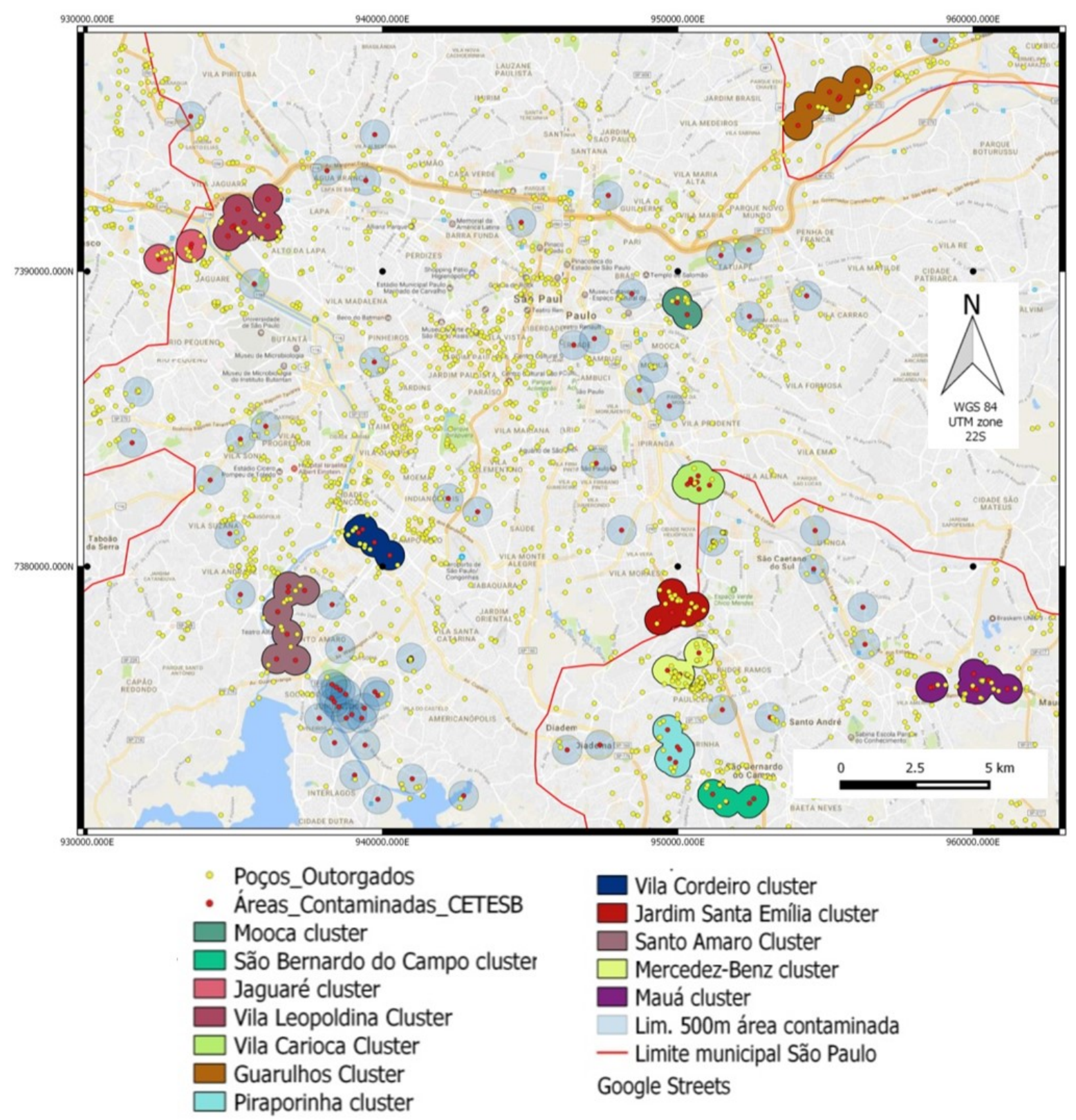

Figura 76 - Mapa de clusters de áreas contaminadas por solventes organoclorados na RMSP (Consentino, 2017)

\subsubsection{Gestão Integrada e a Gestão da Informação}

Tomando-se como exemplo a situação da Região Metropolitana de São Paulo, o Poder Público vem desenvolvendo o gerenciamento das áreas contaminadas conhecidas de forma individual junto aos responsáveis legais, que reconhecidamente possuem contaminação nos limites de sua propriedade. As investigações normalmente se concentram nas porções rasas do aquífero de porosidade intergranular, próximo das áreas fontes reconhecidas. 
Há situações, como na área do Jurubatuba, em que contaminações são reconhecidas em duas ou mais propriedades vizinhas, formando aparentemente uma pluma de contaminação única, superposta e contínua. A abordagem de se realizar a gestão individual das áreas contaminadas é limitada nestes casos, pois os responsáveis legais não envidam esforços conjuntos e coordenados para procurar dimensionar apropriadamente o problema ambiental e caminhar na procura de resolvê-los. A documentação técnica produzida por cada responsável legal é, até hoje, enviada em forma física ou em textos e planilhas eletrônicas para o órgão ambiental, e não há um sistema de informações que seja alimentado rotineiramente e que possibilite uma visualização integral e consistente do problema ambiental, impedindo um planejamento mais lógico e coordenado das atividades de investigação e remediação na escala apropriada.

O trabalho exibido no Anexo 3 (Barbosa et al, 2017) teve o objetivo de desenvolver um sistema piloto de informações geográficas, tomando os processos de áreas contaminadas de uma parte da área do Jurubatuba (antiga ZUPI 131) como fonte de dados, na tentativa de reuni-los para a visualização integrada do problema ambiental. Desta forma, os dados geológicos de sondagens, construtivos de poços de monitoramento e de abastecimento, de monitoramento de cargas hidráulicas e de qualidade da água subterrânea, dentre outros, provenientes de processos físicos de responsáveis legais por áreas contaminadas, foram integrados no modelo de banco de dados Arc Hydro Groundwater. Um dos principais produtos obtidos neste trabalho tem resultados exibidos na Figura 77. Nela, as áreas em vermelho são áreas contaminadas por solventes clorados e em processo de gerenciamento ambiental; as áreas em laranja são aquelas que ainda não foram investigadas, mas que se sabe ter havido a utilização de solventes clorados de forma documentada no passado; as áreas em amarelo são aquelas industriais que tiveram atividades históricas relacionadas com o uso possível de solventes clorados; e as áreas em branco e cinza, respectivamente, são aquelas que não possuem informações e que certamente não estão relacionadas com uso de solventes.

A criação do sistema de informações foi importante para o reconhecimento da seguinte situação: (1) as áreas contaminadas encontram-se em diferentes estágios de investigação, havendo uma grande quantidade de áreas vazias, sem investigação; (2) as informações existentes estão concentradas numa minoria de sítios contaminados (21 propriedades), enquanto a maior parte daquelas que utilizaram solventes clorados no passado ainda não foram investigadas (53 propriedades); (3) a maior parte dos dados disponíveis são provenientes de investigações rasas do 
aquífero sedimentar, enquanto que as investigações do aquífero do manto de intemperismo e do aquífero fraturado são exceções; (4) as várias campanhas de monitoramento de água subterrânea realizadas estão restritas aos poços de monitoramento rasos nas áreas contaminadas conhecidas, representando um desperdício de recursos e uma contribuição pequena para o entendimento do modelo conceitual da contaminação na escala do megasite. Conclui-se que, dada tamanha heterogeneidade das informações disponíveis, é impossível alcançar alguma solução razoável para o problema ambiental sem um trabalho de gestão integrada coordenado pelo Estado, com a cooperação dos responsáveis legais pelas áreas contaminadas.

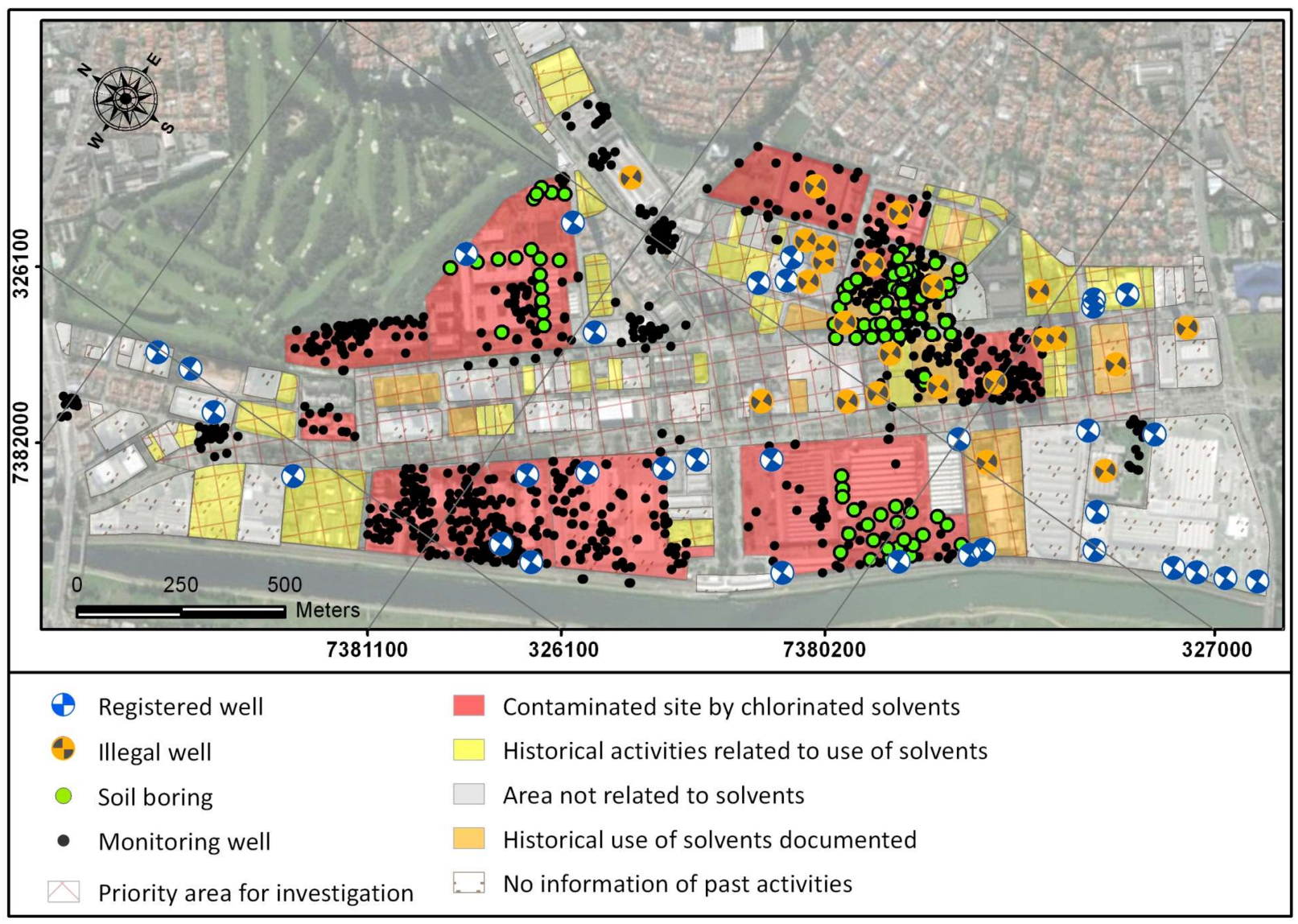

Figura 77 - Áreas privadas numa subregião do Jurubatuba onde o conhecimento da situação ambiental encontra-se em diferentes estágios (Barbosa et al, 2017).

Vários exemplos de gestão integrada de casos complexos de áreas contaminadas por fontes multipontuais encontram-se registrados na literatura (Malina et al, 2006; CLARINET, 2002; Bardos, 2003; Carlon et al, 2008; Schädler et al, 2008; Jamin et al, 2012). Os trabalhos descrevem a abordagem de avaliação de riscos para a priorização de alocação de recursos para a mitigação dos impactos a receptores. Todos os projetos tem em comum o desenvolvimento e a 
aplicação de um sistema geográfico de informações, a existência de uma instituição que coordena integralmente recursos e responsáveis legais pelas áreas contaminadas realizando as ações.

Dentre os casos de gestão descritos, destaque para Malina et al (2006), que descreve o conjunto de ações realizadas no âmbito do projeto WELCOME (Comunidade Econômica Européia) para o gerenciamento da contaminação da água subterrânea em três megasites localizados na Polônia, Dinamarca e Holanda (Porto de Rotterdam). A abordagem é baseada em avaliação de risco para o desenvolvimento de uma Estratégia de Gestão Integrada, que inclui a participação das partes interessadas, o cumprimento da legislação da União Européia, o modelo conceitual da contaminação do megasite e o delineamento de uma zona de gerenciamento de riscos. A Figura 78 apresenta os passos para o desenvolvimento da gestão integrada aplicada no projeto WELCOME, de onde se observa que a consolidação de uma base de dados em sistema geográfico de informações se dá em umas das primeiras etapas do processo, que corresponde à definição das estratégias de gerenciamento integrado.

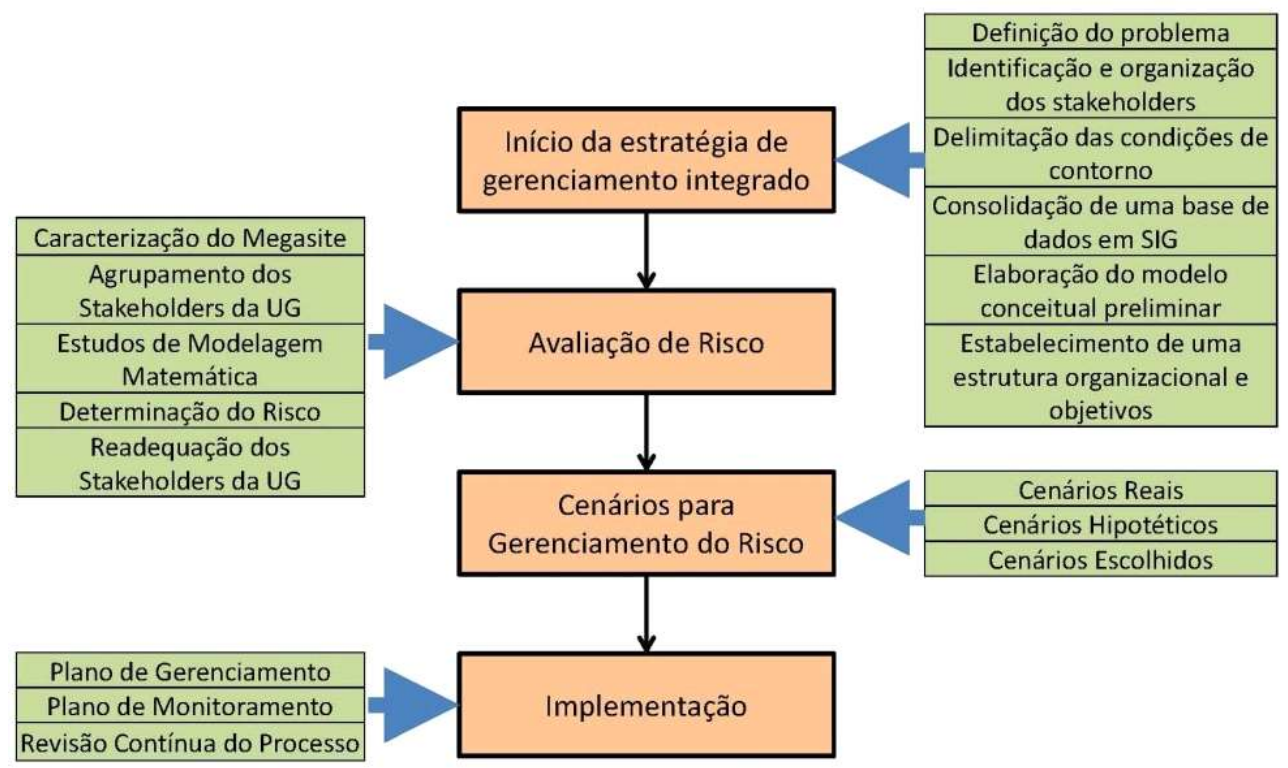

Figura 78 - Estrutura da estratégia de gerenciamento integrado do projeto WELCOMEUE (Malina et al, 2006)

\subsubsection{Proposta de Ação de Gestão para a Área do Jurubatuba}

Até o momento, na área do Jurubatuba, talvez as ações integradas mais importantes realizadas pelo Poder Público para a gestão do problema ambiental foram a interdição de vários poços profundos privados em 2005 e o estabelecimento de uma área de restrição e controle de poços (Figura 79) (L'Apiccirella, 2009). Após estas medidas, não há informações sobre a 
realização de um plano de monitoramento da qualidade da água subterrânea de uma rede de poços profundos, ou mesmo sobre o controle, fiscalização e monitoramento dos poços outorgados e em funcionamento dentro das áreas de restrição e vizinhanças.

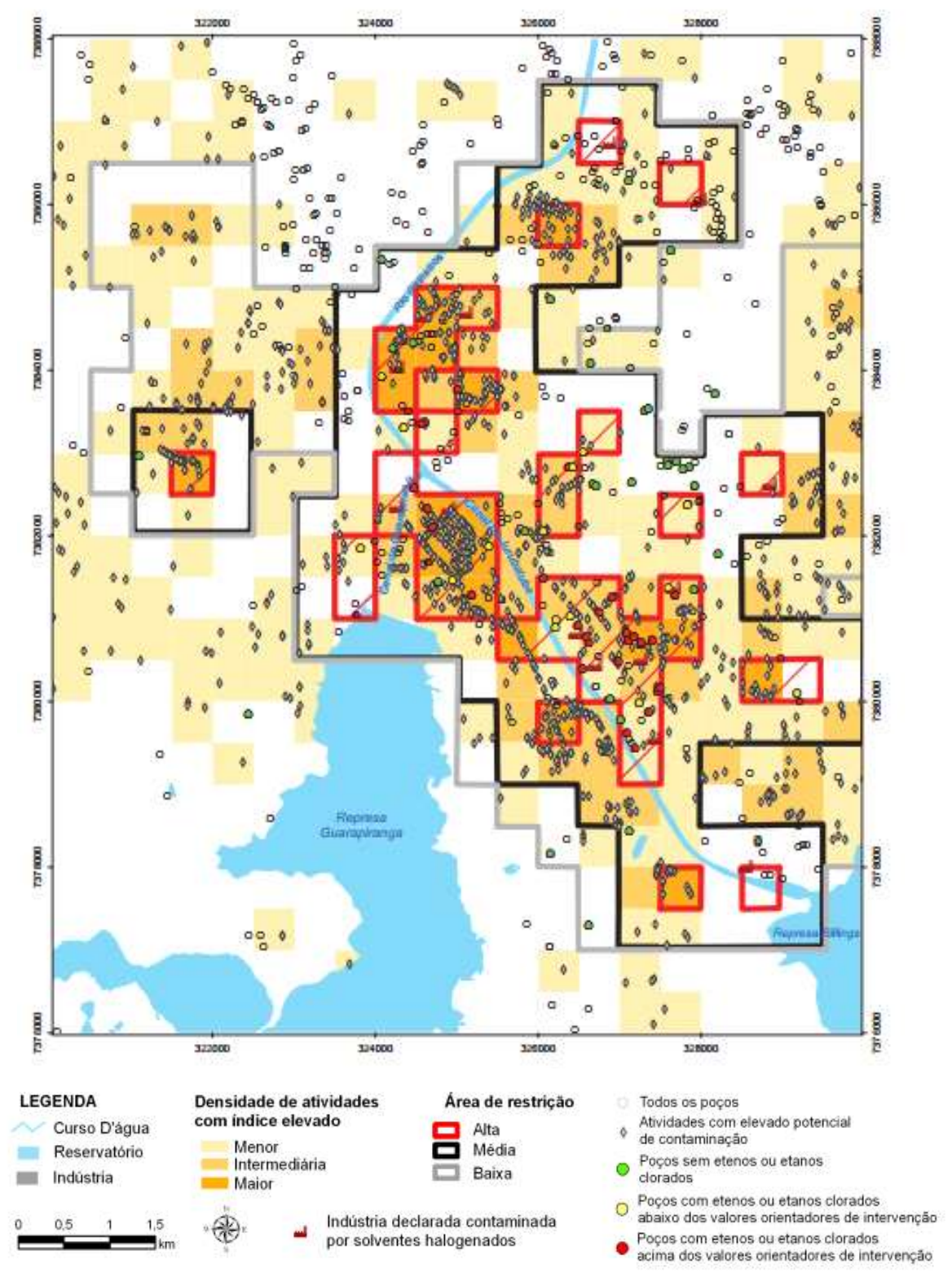

Figura 79 - Áreas de restrição e controle de poços de captação de água subterrânea na região do Jurubatuba SP (L'Apiccirella, 2009)

As ações realizadas, portanto, visaram a apenas afastar o possível receptor usuário da água subterrânea da contaminação, em paralelo ao gerenciamento individualizado das áreas contaminadas conhecidas. As ações de controle ambiental mais privilegiadas realizadas pelos responsáveis legais por áreas contaminadas foram a implementação de ações de engenharia, 
objetivando separar o receptor do solo contaminado, e as ações de remediação do aquífero freático, para promover o controle de migração de vapores em espaços confinados. Efetivamente, entretanto, nenhuma ação coordenada foi realizada para promover a melhoria da qualidade a água subterrânea e nenhum programa de monitoramento contínuo foi realizado para identificar possíveis mudanças nas condições regionais de fluxo e transporte dos contaminantes.

Tais ações teriam grande valor se implementadas, pois a água subterrânea apresenta considerável importância como fonte complementar de abastecimento para a metrópole (Hirata et al., 2012; Bertolo et al., 2015), sendo dotada de valor econômico por apresentar funções ecossistêmicas e prestar vários serviços ambientais (Aly Junior et al., 2015). A água subterrânea desempenhou um importante papel no alívio dos efeitos da seca ocorrida nos anos de 2014 e 2015, que quase levaram ao esgotamento os principais reservatórios de água superficial da RMSP, tendo ocorrido uma grande corrida por usuários privados para a construção de novos poços de abastecimento. O aquífero em Jurubatuba, entretanto, apresentava-se cheio nesta época e havia demanda de utilização da água por vários atores locais, caso se houvesse alguma ação coordenada que oferecesse água do aquífero tratada.

Nexte contexto, uma estratégia de gerenciamento integrado poderia ser elaborada para a região do Jurubatuba, através de um projeto coordenado pelo Poder Público e patrocinado com fundos privados (pelos responsáveis legais da região) e públicos (FEPRAC, acordos de compensação ambiental com Ministério Público), objetivando acelerar os processos de identificação e remediação das áreas contaminadas, enquanto a água subterrânea pudesse ser utilizada pelos usuários do local.

O modelo de estratégia de gerenciamento integrado pode ter inspiração naqueles mencionados anteriormente, como o Malina et al, (2006) (Figura 78), coordenado pelo Estado e com o desenvolvimento de orientações sobre a necessidade e priorização de ações de gerenciamento realizados de forma participativa com os responsáveis legais pelas áreas contaminadas. Estas ações podem incluir elementos de remediação, contenção hidráulica por bombeamento, ações de engenharia, ações institucionais, monitoramento e o compartilhamento das informações do projeto com a população local, de forma a estabelecer um aliança colaborativa.

A proposta de gestão para a área do Jurubatuba poderia passar pela execução das seguintes atividades: 
- Desenvolvimento de banco de dados para gestão integrada e regional de áreas contaminadas e potencialmente contaminadas

O desenvolvimento de um banco de dados é essencial para proporcionar uma visão integrada dos cenários ambientais relacionados ao meio subsuperficial e consequente gestão destes recursos.

O trabalho realizado por Barbosa (2015 - Anexo 3) permitiu o estabelecimento inicial de uma sequência de atividades para construção de um Sistema de Informações Geográficas (SIG) com a finalidade de caracterização da contaminação na antiga ZUPI 131. O trabalho permitiu o levantamento de pontos essenciais a serem considerados na elaboração de um SIG para gestão das áreas contaminadas e a necessidade de integração junto a bases de dados de outros órgãos públicos, tais como DAEE e Vigilância Sanitária Estadual e COVISAs municipais. Por fim, o trabalho sugeriu um modelo de entrada de dados participativo, com a ação de atores como laboratórios, empresas de sondagem, responsáveis técnicos e responsáveis legais, permitindo a criação de um banco que possa atender à toda população, em seus mais diversos níveis de interesse, conforme preconizado como boa prática de um sistema de gestão regional.

O banco de dados desenvolvido poderia ser aplicado inicialmente para a região do Jurubatuba, mas já podendo ser expandido e implementado para todo os casos de áreas contaminadas do Estado de São Paulo.

\section{- Investigações do aquífero raso em áreas públicas}

A Figura 77 apresenta várias áreas com vazios de informação sobre a qualidade do solo e da água subterrânea, especialmente porque muitas áreas suspeitas ainda não tiveram investigações iniciadas. Ademais, sabe-se da existência de ao menos uma área contaminada com DNAPL de PCE em uma via pública. Sem que seja possível identificar o responsável por esta contaminação, ficará por conta do Estado realizar a investigação e controle desta área contaminada. O escopo de investigação envolveria também a realização de serviços de investigação da qualidade dos sedimentos dos córregos, canais e galerias de águas pluviais.

Técnicas de investigação utilizando ferramentas de alta resolução, como o MIP ou o Waterloo profiling, podem ser úteis para a determinação em tempo real de dados do meio físico e de contaminação. $\mathrm{O}$ foco do trabalho seria a investigação do aquífero de porosidade primária raso em áreas e vias públicas. A identificação de contaminantes em determinados locais poderia servir de orientação para o Poder Público exercer uma cobrança mais assertiva sobre o responsável 
legal definido, no sentido de ser envolvido no projeto de gerenciamento integrado e de se executar investigações detalhadas e o controle da contaminação.

\section{- Investigações, intervenções e monitoramento do aquífero fraturado}

Todos os poços de abastecimento profundos existentes e interditados poderiam ser perfilados com uma sonda acústica e flowmeter; alguns poderiam ser selecionados para a execução de ensaios hidráulicos. Os dados levantados seriam utilizados para se decidir pelo selamento ou para transformá-los em sistemas de monitoramento multinível (de 2 ou 3 profundidades discretas), onde informações periódicas de potenciais hidráulicos e de qualidade da água seriam utilizados para avaliar, regionalmente, o fluxo e o transporte de contaminantes, enquanto os dados de imageamento serviriam para ampliar o entendimento do modelo conceitual geológico-estrutural. Novas sondagens profundas (até $300 \mathrm{~m}$ ) com a instalação de sistemas multiníveis convencionais poderiam também ser realizadas em regiões com vazios de informação.

Um monitoramento da qualidade da água subterrânea de poços de abastecimento em funcionamento, outorgados ou ilegais, deveria ser também realizada numa área mais ampla que aquela realizada em 2005 (Figura 20b), a fim de se identificar se houve alguma ampliação da área de aquífero contaminado, originado especialmente pelo bombeamento das regiões aquíferas vizinhas ao Jurubatuba. Uma ampla rede de monitoramento deveria ser implantada visando proteger a saúde de potenciais receptores atuais e para entender melhor o fluxo regional da água subterrânea, a distribuição da contaminação no aquífero fraturado profundo e a possibilidade de ocorrência de atenuação natural.

Simultaneamente aos trabalhos de remediação do aquífero raso em áreas privadas, estudos visando a necessidade de se realizar controles hidráulicos por bombeamento próximos das principais áreas fontes identificadas no aquífero fraturado deveriam ser executados. A água bombeada e tratada poderia ser disponibilizada e utilizada como água de reúso pelos próprios participantes financiadores do projeto, mediante um estudo de viabilidade de projeto.

\section{- Desenvolvimento de novas tecnologias}

Uma outra frente de trabalho seria a de desenvolver tecnologia para suprir necessidades do projeto e dos diferentes atores (privados e públicos) que trabalham com o gerenciamento de aquíferos contaminados. Atualmente, parte das ferramentas mais modernas para investigação de aquíferos fraturados são importadas, com valores elevados e cuja aplicação muitas vezes não atende às necessidades de prazos e de cenários locais. 
Verifica-se a existência de espaço para o desenvolvimento de: (i) ferramentas de perfuração para coleta de amostras de solo e rocha discretas no manto de intemperismo e rocha alterada dura; (ii) equipamentos para a selagem de perfurações, similares aos FLUTe liners; (iii) sistemas de obturadores e transdutores de pressão nacionais; (iv) sistemas de poços multiníveis nacionais para aquíferos fraturados, similares aos sistemas FLUTe e Westbay.

\section{Capítulo 6 - Considerações Finais}

Neste trabalho, procurou-se apresentar os resultados de experiências em investigações de contaminação de aquíferos fraturados por compostos organoclorados que pudessem ser apresentados como as principais bases técnicas para a gestão de áreas contaminadas neste contexto.

As técnicas e equipamentos utilizados na investigação de aquíferos fraturados contaminados foram testados e avaliados neste trabalho, podendo servir como uma referência para a elaboração de um escopo de investigação de áreas contaminadas por fontes individuais. Resumidamente, mostra-se relevante a utilização, de forma ordenada, de (i) técnicas de mapeamento geológico-estrutural de afloramentos, (ii) a realização de perfurações no manto de intemperismo e na rocha com recuperação contínua de testemunhos de sondagem, (iii) a realização de perfilagens geofísicas nas perfurações novas e em poços de abastecimento profundos existentes para melhorar o modelo geológico conceitual, (iv) a realização de perfilagens com medidores de fluxo (flowmeter), (v) a impermeabilização temporária do furo de sondagem novo, seja com liner ou com obturadores, (vi) a execução de ensaios hidráulicos e coleta de amostras de água discretas com obturadores, (vii) a instalação de sistemas multiníveis de monitoramento no manto de intemperismo e na rocha fraturada, (viii) a realização de análises físicas e químicas em testemunhos de sondagem para identificar se há massa de contaminantes na rocha, (ix) o monitoramento da qualidade química, isotópica e bacteriológica da água subterrânea dos sistemas multiníveis instalados. Este trabalho também avaliou a aplicação de alguns equipamentos, identificando aqueles que apresentam boa relação custo/benefício, disponibilidade e necessidade de utilização de mão de obra especializada.

Outro aspecto abordado neste trabalho relaciona-se com as ideias para a realização de uma gestão mais pertinente de áreas contaminadas por fontes multipontuais, como a que ocorre na região do Jurubatuba, mas que sabe-se haver potencial de ocorrência em vários outros locais da Região Metropolitana de São Paulo. Destaque para a necessidade, na visão deste autor, $(i)$ de se 
proceder a realização de projetos coordenados pelo Estado e com a participação dos responsáveis legais identificados, para a realização da gestão integrada destas áreas; (ii) de se desenvolver uma grande base de dados em sistema geográfico de informações para guiar e planejar as ações de gestão baseada em riscos ambientais; (iii) de se proceder investigações e ações de remediação coordenadas no aquífero raso, enquanto se realiza controle hidráulico e monitoramento do aquífero profundo, visando proteger a saúde de receptores usuários de água subterrânea de outros locais; e (iv) proceder o desenvolvimento de tecnologias nacionais para a investigação e monitoramento de áreas contaminadas complexas.

A perspectiva trazida pela Decisao de Diretoria 38/2017 (CETESB, 2017) é a de que uma grande quantidade de novas áreas contaminadas em áreas industriais serão descobertas em futuro próximo. Os casos conhecidos de áreas contaminadas por solventes organoclorados tenderão a sofrer incremento, assim como aqueles sítios contaminados em regiões de aquífero fraturado. A combinação situações de (i) meio físico geológico/hidrogeológico naturalmente de difícil caracterização, com (ii) contaminante de elevado potencial de espalhamento, de elevada toxicidade e de complexo mecanismo de degradação, com (iii) existência de múltiplas fontes de contaminação, e (iv) com existência de elevado número potencial de receptores, representados pelos usuários de poços de abastecimento, representa uma situação de grande desafio técnico e gerencial.

Será inevitável, desta forma, que se crie um corpo técnico treinado no assunto e que atue no Estado, nas empresas de consultoria e nas empresas responsáveis pelo gerenciamento ambiental. Possa este trabalho contribuir para trilhar adequadamente este caminho. 


\section{Referências Bibliográficas}

Aly Junior, O., Bertolo, R., Hirata, R., \& Pugga, B. (2015). Princípios da valoração dos recursos hídricos subterrâneos impactados por atividades contaminantes. In: M. P. Paulo, Temas de Direito Ambiental (pp. 161-184). São Paulo: Imprensa Oficial do Estado de São Pauo.

Barbosa, M. (2015). Caracterização hidráulica do aquífero fraturado na região industrial do Jurubatuba. Projeto de tese de doutorado, IGc-USP.

Barbosa, M. (2015). Sistema de Informações Geográficas aplicado ao gerenciamento da contaminação da antiga ZUPI 131, Jurubatuba, São Paulo. São Paulo: Dissertação de mestrado, IGc-USP.

Barbosa, M., Bertolo, R., \& Hirata, R. (2017). A Method for Environmental Data Management Applied to Megasites in the State of Sao Paulo, Brazil. Journal of Water Resource and Protection, 9 (3), pp. 322-338.

Bardos, P. (2003). Sharing Experience in the Management of Megasites: Towards a Sustainable Approach in Land Management of Industrially Contaminated Sites. Report of the NICOLE Workshop.

Bertolo, R., Alves, C., \& Maximiano, A. (2017). Áreas Contaminadas. In: Geologia de Engenharia e Ambiental (1a ed., Vol. 3, pp. 227-251). São Paulo: ABGE.

Bertolo, R., Hirata, R., Conicelli, B., Simonato, M., Pinhatti, A., \& Fernandes, A. (2015). Água subterrânea para abastecimento público na Região Metropolitana de São Paulo: é possível utilizá-la em larga escala? Revista DAE, 63, pp. 6-17.

Camilo, J. (2013). Application of the discrete fracture network approach to characterize bedrock aquifer contamination at a former dry cleaner site. Master's thesis, University of Waterloo, Canada.

Carlon, C., Pizzol, L., Critto, A., \& Marcomini, A. (2008). A Spatial Risk Assessment Methodology to Support Remediation of Contaminated Land. Environment International .

CEPAS-USP. (2016). Estudo hidrogeológico para o diagnóstico da disponibilidade hídrica subterrânea para abastecimento de água na Região Metropolitana de São Paulo. SABESP: Relatório Técnico (circulação restrita).

CETESB. (2017). Decisão de Diretoria n 038/2017/C, de 07 de fevereiro de 2017. São Paulo: CETESB.

CETESB. (2015). Relação de áreas contaminadas e reabilitadas no Estado de São Paulo. São Paulo: CETESB.

Chartrand, M., Morril, P., Lacrampe-Couloume, G., \& Lollar, B. (2005). Stable isotope evidence for biodegradation of chlorinated ethenes at a fractured bedrock site. Environmental Sciente \& Technology, 39 (13), pp. 4848-4856.

Cherry, J., Parker, B., \& Keller, C. (2007). A new depth-discrete multilevel monitoring approach for fractured rock. Groundwater Monitoring and Remediation , 27 (2), 57-70.

CLARINET. (2002). Review of Decision Support Tools for Contaminated Land Management: An Overview.

Consentino, B. (2017). Avaliação da qualidade da água subterrânea de poços de abastecimento 
próximos a áreas contaminadas por compostos organoclorados na Região Metropolitana de São Paulo. Relatório de Trabalho de Formatura., IGc-USP.

Cruden, D. (1988). Subsurface fracture surveys using a borehole television camera and acoustic televierwer: discussion. Canadian Geotechnical Journal , 25, 843.

Cunha, R. (2017). CETESB's contaminated sites regulations. Material do curso "The groundwater pollution and hydrology course" Brasil edition., Santos, SP.

Day-Lewis, F., Johnson, C., Paillet, F., \& Halford, K. (2011). A computer program for flow-log analysis of single holes (FLASH). Groundwater , 49 (6), 926-931.

Dietrich, P., Butler, J., \& Flaib, K. (2008). A rapid method for hydraulic profiling in unconsolidated formations. Groundwater , 46 (2), 323-328.

Domenico, P., \& Schwartz, F. (1997). Physical and chemical hydrogeology (2nd edition ed.). New York: John Wiley \& Sons.

Einarson, M., \& Cherry, J. (2002). A new multilevel groundwater monitoring system using multichannel tubing. Groundwater Monitoring \& Remediation , 22 (4), 52-65.

Elis, V., \& Zuquette, L. V. (1998). Aplicação de Técnicas geofísicas no estudo de área de disposição de resíduos urbanos. Geotecnia (Lisboa) , 84, pp. 5-22.

FABHAT-SERVMAR. (2012). Mapeamento das áreas potenciais de risco de contaminação das águas subterrâneas na UGHRI 6 e suas regiões de recarga. São Paulo: FABHAT.

Fanti, A., Bertolo, R., Vogado, F., Cagnon, F., \& Queiroz, A. P. (2017). Application of geophysical logging and straddle packers for the investigation of a fractured aquifer in a contaminated area by chlorinated solvents in Sao Paulo State, Brazil. Journal of Water Resource and Protection, 10, pp. 1145-1168.

Fernandes, A. (2008). Aquíferos fraturados: uma revisão dos condicionantes geológicos e dos métodos de investigação. Revista do Instituto Geológico , 1, pp. 49-72.

Fernandes, A. (1997). Cenozoic tectonics of the Piracicaba River Basin and its application to hydrogeology (in Portuguese). Sao Paulo, Brazil: Doctorate thesis. Institute of Geosciences, University of Sao Paulo.

Fernandes, A. J., Fiume, B., Bertolo, R., \& Hirata, R. (2016). Modelo geométrico de fraturas e análise da tectônica rúptil aplicados ao estudo do fluxo do aquífero cristalino, São Paulo SP. Geologia USP Série Científica, 16 (3), 71-88.

Ferreira, S. (2015). Processos microbiológicos associados à degradação de solventes halogenados na água subterrânea - biogeoquímica na área do Jurubatuba, São Paulo, SP. Projeto de Dissertação de Mestrado, IGc-USP.

Fiume, B. (2014). Geologia estrutural de detalhe para elaboração de modelo conceitual de circulação de água subterrânea: estudo de caso em Jurubatuba, SP. São Paulo: Dissertação de Mestrado, IGc-USP.

Francese, R., Mazzarini, F., Bistacchi, A., Morelli, G., Pasquare, G., Praticelli, N., et al. (2009). A structural and geophysical approach to the study of fractured aquifers in the ScansanoMagliano in Toscana Ridge, southern Tuscany, Italy. Hydrogeology Journal , 17, 1233-1246.

Freeze, A., \& Cherry, J. (1979). Groundwater. Prentice-Hall.

Hirata, R., Bertolo, R., Conicelli, B., \& Maldaner, C. (2012). Hidrogeologia da Bacia 112 
Hidrográfica do Alto Tietê. In: ABGE, Twin Cities - Solos das Regiões Metropolitanas de São Paulo e Curitiba (pp. 65-80). São Paulo.

Hunkeler, D., Aravena, R., \& Butler, B. (1999). Monitoring microbial dechlorination of tetrachloroethene (PCE) in groundwater using compound-specific stable carbon isotope ratios: microcosm and field studies. Environmental Science \& Technology, 33, pp. 2733-2738.

Hurley, J. (2003). Rock core investigation of DNAPL penetration and persistence in fractured sandstone. Canada: Master's thesis, University of Waterloo.

Hvorslev, M. (1951). Time Lag and Soil Permeability in Ground-Water Observations. Vicksburg, Mississippi: Waterways Exper. Sta. Corps of Engrs, U.S. Army,.

IG-SMA, Instituto Geológico. (1993). Aids of the Geological Physical Environment to the Planning of Campinas Municipality (Brazil) (In Portuguese). Sao Paulo, Brazil: Technical report, volume II.

Jamin, P., Dollé, F., Chisala, B., Orban, P., Popescu, I., Heivaux, C., et al. (2012). A Regional Flux-Based Risk Assessment Approach for Multiple Contaminated Sites on Groundwater Bodies. Journal of Contaminant Hydrology, 127, pp. 65-75.

Johnson, C., Mondazzi, R., \& Joesten, P. (2009). Borehole geophysical investigation of a formerly used defense site, Machiasport, Maine, 2003-2006. USGS Scientific Investigations Report.

Keller, C. (2004). How to locate, and flow test, every major fracture in a borehole in one hour. Proceedings of 2004 USEPA-NGWA Fractured Rock Conference: State of the Science and Measuring Success in Remediation. Westerville, OH, USA: NGWA.

Kennel, J. (2008). Advances in rock core VOC analyses for high resolution characterization of chlorinated solvent contamination in a dolostone aquifer. Canada: Master's thesis, University of Waterloo.

Keys, S. (1990). Techniques of water-resources investigations of the United States Geological Survey. USGS Report.

Kuepper, B. (2003). Notas do curso "Fluxo de Água Subterrânea em Meios Fraturados conceitos básicos". São Paulo.

Kuepper, B., \& McWhorter, D. (1991). The behaviour of dense, non-aqueous phase liquids in fractured clay and rock. Journal of Ground Water , 29 (5), 716-728.

Kuepper, B., Weathall, G., Smith, J., Leharne, S., \& Lerner, D. (2003). An Illustrated Handbook of DNAPL Transport and Fate in the Subsurface. (Vol. 133). United Kingdom: R\&D Publication.

Lane, J. (2002). An integrated geophysical and hydraulic investigation to characterize a fractured-rock aquifer, Norwalk, Connecticut. U.S. Dept. of the Interior, U.S. Geological Survey, 97p.

Lapcevic, P. (1988). Results of borehole packer tests at the Ville Mercier Groundwater Treatment Site. Burlington, Ontario: National Water REsearch Institute.

L'Apiccirella, E. (2009). Contaminação e áreas de restrição de uso de água subterrânea no entorno do canal Jurubatuba em São Paulo SP. Dissertação de Mestrado. IGc-USP.

Lau, J., Auger, L., \& Bisson, J. (1987). Subsurface fracture surveys using a borehole television 
camera and acoustic televiewer: reply. Canadian Geotechnical Journal , 24, 499-508.

Le Borgne, T., Bour, O., Paillet, F., \& Caudal, J. (2006). Assessment of preferential flow path connectivity and hydraulic properties at single-borehole and cross-borehole scales in a fractured aquifer. Journal of Hydrology, 328, 347-359.

Levison, J., \& Novakowski, K. (2012). Rapid transport from the surface to wells in fractured rock: a unique infiltration tracer experiment. Journal of Contaminant Hydrology, 131, 29-38.

Lojkasek-Lima, P. (2016). Caracterização de detalhe do perfil vertical de contaminação em aquífero cristalino alterado - aplicação da metodologia "Discrete Fracture Network" (DFN) Jurubatuba - São Paulo. São Paulo: Exame de qualificação de doutorado. IGc-USP.

Lojkasek-Lima, P., Aravena, R., Parker, B., \& Cherry, J. (2012). Fingerprinting TCE in a bedrock aquifer using compound specific isotope analysis. Groundwater , 50 (5), pp. 754-764.

Malina, G., Krupanek, J., Sievers, J., Grossmann, J., ter Meer, J., \& Rijnaarts, H. (2006). Integrated Management Strategy for Complex Groundwater Contamination at a Megasite Scale. In: I. A. Twardowska, Soil and Water Pollution Monitoring, Protection and Remediation (pp. 567-577). Dordrecht: Springer.

Meyer, J. (2005). Migration of a mixed organic contaminant plume in a multilayer sedimentary rock aquifer system. University of Waterloo, Canada: Master's Thesis.

Meyer, J., Parker, B., \& Cherry, J. (2008). Detailed hydraulic head profiles as essential data for defining hydrogeologic units in layered fractured sedimentary rock. Environmental Geology, $56,27-44$.

Monteiro, M. (2016). Contribuição à caracterização hidrogeológica de maciços fraturados e solos residuais em projetos de obras subterrâneas na Região Metropolitana de São Paulo. IGc-USP. Dissertação de Mestrado.

Morin, R., Carleton, G., \& Poirier, S. (1997). Fractured-aquifer hydrogeology from geophysical logs: the Passaic Formation, New Jersey. Groundwater , 35 (2), 328-338.

Morin, R., Godin, R., Nastev, M., \& Rouleau, A. (2007). Hydrogeologic controls imposed by mechanical stratigraphy in layered rocks of the Chateauguay River Basin, a US-Canada transborder aquifer. Journal of Geophysical Research, 112.

Novakowski, K. (2000). Fate and transport in fractured rock. In: J. Lehr, Standard Handbook of Environmental Science, Health and Technology (pp. 4.74 - 4.86). McGraw-Hill.

Novakowski, K., Bickerton, G., Lapcevic, P. V., \& Ross, N. (2006). Measurements of groundwater velocity in discrete rock fractures. Journal of Contaminant Hydrology , 82, 4460 .

O'Leary, D., Friedman, J. D., \& Pohn, H. A. (1976). Lineament, linear, lineation: some proposed new standards for old terms. Geological Society American Bulletin , 87, 1463-1469.

Paillet, F. (2000). A field technique for estimating aquifer parameters using flow log data. Groundwater , 34 (5), 997-1010.

Paillet, F. (1998). Flow modelling and permeability estimation using borehole flow logs in heterogeneous fractured formations. Water Resources Research, 34 (5), 997-1010.

Paillet, F. (1995). Using borehole flow logging to optimize hydraulic test procedures in heterogeneous fractured aquifers. Hydrogeology Journal , 3 (3), 4-20. 
Paillet, F., Williams, J., Urik, J., Lukes, J., Kobr, M., \& Mares, S. (2012). Cross-borehole flow analysis to characterize fracture connections in the Melechov Granite, Bohemian-Moravian Highland, Czech Republic. Hydrogeology Journal , 20 (1), 143-154.

Pankow, J., \& Cherry, J. (1996). Dense chlorinated solvents and other DNAPLs in groundwater: history, behaviour and remediation. Portland, Oregon: Waterloo Press. 525p.

Parker, B. (2007). Investigating contaminated sites on fractured rock using the DFN approach. Proceedings at the USEPA/NGWA Fractured Rock Conference: state of the science and measuring success in remediation. Portland, Maine. , 150-168.

Parker, B., Cherry, J., \& Chapman, S. (2012). Discrete Fracture Network Approach for Studying Contamination in Fractured Rock. (D. 10.4409/Am-052-12-0046, Ed.) AQUA mundi , Am06052, 101 - 116.

Pehme, P. (2012). New approaches to the collection and interpretation of high sensitivity temperature logs for detection of groundwater flow in fractured rock. University of Waterloo: Tese de Doutorado.

Pehme, P., Cherry, ,. J., Parker, B., \& Greenhouse, J. (2010). Improved Resolution of Ambient Flow through Fractured Rock with Temperature Logs. Groundwater , 48 (2), 191-205.

Pehme, P., Parker, B., Cherry, J., \& Greenhouse, J. (2007). Identification of hydraulically active fractures in rock using high resolution temperature logging while avoiding borehole crossconnection.

Pehme, P., Parker, B., Cherry, J., Molson, J., \& Greenhouse, J. (2013). Enhanced detection of hydraulically active fractures by temperature profiling in lined heated bedrock boreholes. Journal of Hydrogeology , 484, 1-15.

Pino, D. (2017). Caracterização hidráulica de superdetalhe do aquífero cristalino fraturado do Jurubatuba, São Paulo SP. São Paulo: Exame de qualificação de doutorado. IGc-USP.

Pino, D. (2012). Structural Hydrogeology in the Kenogamy Uplands, Quebec, Canada. Chicoutimi, Canada: MSc Thesis. L'Université du Québec .

Priest, S. (1993). Discontinuity analysis for rock engineering. Londres: Chapman \& Hall.

Quinn, P., Cherry, J., \& Parker, B. (2012). Hydraulic testing using a versatile straddle packer system for improved transmissivity estimation in fractured-rock boreholes. Hydrogeology Journal , 20 (8), 1529-1547.

Quinn, P., Cherry, J., \& Parker, B. (2011). Quantification of non-Darcian flow observed during packer testing in fractured sedimentary rock. Water Resources Research , 47, 15p.

Quinn, P., Parker, B., \& Cherry, J. (2011). Using constant head step tests to determine hydraulic apertures in fractured rock. Journal of Contaminant Hydrology , 126 (1-2), 85-99.

Reynolds, D. A., \& Kuepper, B. H. (2002). Numerical examination of the factors controlling DNAPL migration through a single fractures. Groundwater , 4, 368-377.

Riccomini, C., Coimbra, A., \& Takiya, H. (1992). Tectônica e sedimentação na Bacia de São Paulo. In: ABAS-ABGE-SBG, Problemas geológicos e geotécnicos na Região Metropolitana de São Paulo (pp. 21-45). São Paulo: ABGE.

Robinson, D., Binley, A., Crook, N., \& Slater, L. (2008). Advancing process-based watershed hydrological research using near surface geophysics: a vision for, and review of, electrical and 
magnetic geophysical methods. Hydrological Process , 22, 3604-3635.

São Paulo (SMA, SERHS, SES). (2006). Resolução conjunta SMA/SERHS/SS n. 3, de 21.06.2006.

São Paulo (SMA, SSE). (1999). Projeto Jurubatuba: restrição e controle de uso de água subterrânea. São Paulo, SP: DAEE/IG.

Schädler, S., Morio, M., Finkel, M., \& Trefry, M. (2008). Land-Use Related Cost Estimates for Contaminated Site Development: Consequences of Uncertainty for Planning and Investment Decisions. Proceedings Groundwater Quality 2007 Conference, (pp. 539-546). Fremantle.

Sherwood, B., Slater, G., Sleep, B., Witt, M., Klecka, G., Harkness, M., et al. (2001). Stable carbon isotope evidence for intrinsic bioremediation of tetrachloroethene and trichloroethene at area 6, Dover Air Force Base. Environmental Science \& Technology, 35, pp. 261-269.

SiREM Lab. (2017). Interpretation of Gene-Trac Dhc, vcrA, bvcA and tceA Assays. www.siremlab.com.

Sterling, S., Parker, B., Cherry, ,. J., Williams, J., Lane Jr., J., \& Haeni, F. (2005). Vertical cross contamination of trichlroethylene in a borehole in fractured sandstone. Groundwater , 43 (4), pp. 557-573.

Terzaghi, R. (1965). Sources of error in joint surveys. Géotechnique , 15 (3), 287-304.

USEPA United States Environmental Protection Agency. (2016). Regional Screening Levels (RSLs) Generic Tables. Acesso em 19/06/2017: https://www.epa.gov/risk/regional-screeninglevels-rsls-generic-tables-may-2016.

Vaz, L. (1996). Classificação genética dos solos e dos horizontes de alteração de rocha em regiões tropicais. Solos e Rochas , 19 (2), 117-136.

Wahnfried, I. (2010). Hydrogeologycal conceptual model of the Serra Geral Aquitard and Guarani Aquifer in Ribeirão Preto, São Paulo, Brazil (in portuguese). Sao Paulo, Brazil: Doctorate thesis. Institute of Geosciences, University of Sao Paulo.

Wiedemeier, T., Rifai, H., Wilson, J., \& Newell, C. (1999). Natural attenuation of fuels and chlorinated solvents in the subsurface. New York: John Wiley \& Sons.

Williams, J., \& Paillet, F. (2002). Using flowmeter tests to define hydraulic connections in the subsurface: a fractured shale example. Journal of Hydrology , 265, 100-117.

Williams, J., Lacombe, P., Johnson, C., \& Paillet, F. (2007). Cross-borehole flow tests and insights into hydraulic connections in fractured mudstone and sandstone. Proceedings of Symposium on the Application of Geophysics to Engineering and Environmental Problems SAGEEP, (pp. 1140-1152). Denver, CO. 


\section{Anexos}

\section{ANEXO 1 - Artigo:}

Fernandes, A. J., Fiume, B., Bertolo, R., \& Hirata, R. (2016). Modelo geométrico de fraturas e análise da tectônica rúptil aplicados ao estudo do fluxo do aquífero cristalino, São Paulo SP. Geologia USP Série Científica, 16 (3), 71-88.

\section{ANEXO 2 - Artigo:}

Fanti, A., Bertolo, R., Vogado, F., Cagnon, F., \& Queiroz, A. P. (2017). Application of geophysical logging and straddle packers for the investigation of a fractured aquifer in a contaminated area by chlorinated solvents in Sao Paulo State, Brazil. Journal of Water Resource and Protection, 9 (10), 1145-1168

\section{ANEXO 3 - Artigo:}

Barbosa, M., Bertolo, R., \& Hirata, R. (2017). A Method for Environmental Data Management Applied to Megasites in the State of Sao Paulo, Brazil. Journal of Water Resource and Protection, 9 (3), 322-338. 


\title{
Modelo geométrico de fraturas e análise da tectônica rúptil aplicados ao estudo do fluxo do aquífero cristalino, São Paulo (SP) \\ Geometric fracture model and brittle tectonic analysis applied to the study of the crystalline aquifer flow, São Paulo (SP)
}

\author{
Amélia João Fernandes ${ }^{1}$, Bruna Fiume ${ }^{2}$, Reginaldo Bertolo ${ }^{3}$ e Ricardo Cesar Aoki Hirata ${ }^{3}$ \\ 'Instituto Geológico - SMA, Rua Joaquim Távora, 822, CP 972, CEP 01065-970, São Paulo, SP, Brasil \\ (amelia.ffernandes@gmail.com) \\ ${ }^{2}$ Companhia de Pesquisa de Recursos Minerais - CPRM, Belo Horizonte, MG, Brasil (bruna.fiume@cprm.gov.br) \\ 3Universidade de São Paulo - USP, Instituto de Geociências, São Paulo, SP, Brasil (bertolo@usp.br; rhirata@usp.br)
}

Recebido em 14 de agosto de 2015; aceito em 10 de maio de 2016

\begin{abstract}
Resumo
A análise detalhada de estruturas rúpteis é uma ferramenta ainda pouco utilizada no estudo de aquíferos fraturados, apesar de ser complementar aos dados obtidos em poços e de fornecer elementos de grande relevância para a elaboração de modelos conceituais de fluxo de água subterrânea. Este trabalho apresenta análise de dados coletados em pedreiras do Complexo Embu, visando elaborar modelo geométrico de fraturas em granitos e gnaisses pré-cambrianos, de modo a fornecer subsídios a projeto mais amplo de caracterização de contaminação de aquíferos por solventes organoclorados da área industrial do Jurubatuba, na cidade de São Paulo. Os dados coletados ao longo de scanlines, com correção do viés de orientação, e em observações pontuais, permitiram caracterizar grupos de fraturas, bem como seus respectivos campos de esforços e idades relativas. Os grupos subverticais de expressão regional são extrapoláveis para a área do Jurubatuba, complementando os dados obtidos em perfilagens de poços verticais. A transmissividade relativa dos grupos de fraturas é indicada pelo seu grau de intemperismo, presença de vegetação e de saídas de água. A pedreira constituída de gnaisses é o melhor análogo da geologia da área industrial. Sua foliação, afetada por dobra cilíndrica aberta e assimétrica, é de baixo a médio mergulho para $\mathrm{SE}$ ou NW e foi intensamente reativada como fraturas contínuas e de baixo mergulho, cuja transmissividade é relativamente elevada. Abundantes fraturas NW subverticais podem ser o principal caminho para o fluxo vertical. Fraturas subverticais NE são transmissivas, no entanto apresentam grande espaçamento e, por isso, são consideradas de menor importância para o fluxo, da mesma forma que as frequentes fraturas subverticais $\mathrm{EW}$, de menor transmissividade relativa.
\end{abstract}

Palavras-chave: Fraturas; Aquífero cristalino; Geologia estrutural; Tectônica rúptil; São Paulo; Brasil.

\begin{abstract}
Detailed structural analysis is still incipiently applied to fractured aquifers, although it provides relevant data for the elaboration of more realistic groundwater flow conceptual models and is complementary to hydraulic data obtained from boreholes. This article presents an analysis of data collected in quarries of the Embu Complex aiming at elaborating a geometrical fracture model for Precambrian granites and gneisses, in order to provide a basis for characterizing the aquifer contamination by chlorinated solvents in the Jurubatuba urban and industrial area, located in the São Paulo municipality. The data collected along scanlines, to which an orientation bias correction was applied, and in isolated spots, permitted to characterize fractures sets, as well as their respective stress fields and age relationships. The main subvertical sets that occur in the quarries are likely to be present also in the Jurubatuba area, and complement the fracture data obtained through vertical well profiling. The relative transmissivity of the fracture sets is indicated by the weathering intensity, as well as presence of vegetation and water seepage. The quarry constituted by gneiss is the best analog of the geology of the industrial area. The gneiss foliation draws an open and asymmetric cylindrical fold and dips in a low angle to SE or NW, being intensively reactivated as continuous low-dip and transmissive fractures. Abundant subvertical NW fractures are probably the main vertical flow path. Subvertical NE fractures are transmissive, however are largely spaced and, as a result, are considered less important for water flow, as are the quite frequent subvertical EW fractures, due to their relatively low transmissivity.
\end{abstract}

Keywords: Fractures; Crystalline aquifer; Structural geology; Brittle tectonics; São Paulo; Brazil. 


\section{INTRODUÇÃO}

Esta pesquisa teve como objetivo elaborar um modelo geométrico de fraturas em granitos e gnaisses pré-cambrianos a partir de uma análise detalhada da deformação rúptil, de modo a contribuir para a elaboração de modelo conceitual de fluxo em aquífero fraturado da área industrial do canal do Jurubatuba, na cidade de São Paulo. A aplicação desta área da geologia estrutural é de grande relevância para a locação de poços de água subterrânea; para a geologia de engenharia, relacionada a construção de túneis, estradas e barragens; e para estudos de contaminação de aquíferos. Este trabalho, especificamente, insere-se no Projeto Jurubatuba, que visa a investigação de contaminação de água subterrânea por solventes organoclorados na porção sul da cidade de São Paulo. Esta contaminação atinge tanto a cobertura sedimentar como os gnaisses, granitos e xistos do aquífero fraturado subjacente. Neste, a circulação de água subterrânea acontece ao longo de uma rede de fraturas cujas características geométricas (tais como, espaçamento e comprimento) e de hidráulica (transmissividade) são de difícil previsão. Soma-se a isso o fato dos contaminantes dissolvidos terem alcançado profundidades da ordem de várias dezenas de metros, em resposta aos potenciais hidráulicos verticais descendentes, provocados pelo bombeamento do aquífero da região. Assim, este estudo constitui grande desafio e o modelo conceitual elaborado deverá contribuir para o planejamento das demais atividades do projeto, tais como o desenho e emprego de técnicas sofisticadas de monitoramento e de caracterização de fraturas (mapeamento de fraturas hidraulicamente ativas utilizando um Flute liner, instalação de portas de monitoramento em sistema multinível), inéditas no país, almejando definir as bases para a gestão do problema da contaminação.

No Brasil, são escassos os trabalhos que aplicaram análise estrutural detalhada ao estudo de aquíferos fraturados, podendo ser mencionados Fernandes e Rudolph (2001) para a região de Campinas (SP), e Alves (2008), sobre contaminação em rochas do Complexo Embu da região de Cotia (SP). Também há exemplos nacionais de estudos de deformação rúptil aplicados à elaboração de modelos conceituais de circulação de água subterrânea em rochas vulcânicas (Fernandes et al., 2011; Wahnfried, 2010). A literatura internacional tem demonstrado vínculo entre esforços neotectônicos e orientação dos caminhos preferenciais de circulação de água subterrânea (Barton et al., 1995; Ferrill et al., 1999; Morin e Savage, 2003), sendo que Fernandes e Rudolph (2001) sugeriram, com base em análise estrutural e orientação de lineamentos, que a direção das fraturas mais transmissivas pode variar em distâncias relativamente pequenas, como também demonstrado por Talbot e Sirat (2001). Maloney et al. (2006) concluem que tais variações são causadas pelo fato dos esforços tectônicos (principalmente até $300 \mathrm{~m}$ de profundidade) serem controlados por fatores locais.
A análise estrutural deste trabalho teve como base o levantamento sistemático de fraturas em pedreiras localizadas dentro da faixa de ocorrência do Complexo Embu, a uma distância, em linha reta, que varia entre 13 e $24 \mathrm{~km}$ para oeste da área contaminada do Jurubatuba (Figura 1), já que neste local boas exposições de rocha são inexistentes, em vista da densa ocupação urbana. Os dados coletados por Fiume (2014) são aqui analisados e parcialmente reinterpretados e complementados. A autora também realizou coleta de dados de fraturas, em poços verticais localizados na área do Jurubatuba, através de perfilagens acústicas (ATV) e ópticas (OTV) e de medida de velocidade de fluxo, através de flowmeter. Estes dados permitiram realizar análise estrutural local e medição do fluxo associado a fraturas específicas. O levantamento de fraturas nas pedreiras, aqui apresentado, foi essencial para inferir a ocorrência de fraturas de mergulhos elevados, que são subestimadas nas perfilagens de poços, devido ao fato destes serem verticais; este assunto será tratado de forma mais aprofundada em artigo futuro. Além disso, os poços não possibilitam a observação de feições importantes para a construção do modelo geométrico, tais como comprimentos e interação entre fraturas.

Assim esta pesquisa preenche uma lacuna importante relativa ao conhecimento das características geométricas da rede de fraturas na região de interesse e fornece uma análise preliminar dos caminhos preferenciais de circulação de água subterrânea, essenciais para a elaboração do modelo conceitual de fluxo de água subterrânea. Este foi elaborado com base na identificação: (1) dos grupos de fraturas de expressão regional, cuja ocorrência, portanto, pode ser esperada na área do Jurubatuba; (2) do regime tectônico e campos de esforços em que tais grupos de fraturas foram gerados; (3) da idade relativa entre os grupos, pois estes podem implicar em maior ou menor continuidade das suas fraturas; e (4) da transmissividade relativa entre os grupos de fraturas com base na observação sistemática de feições que indiquem presença de fluxo de maior ou menor intensidade.

\section{MÉTODOS}

As pedreiras onde foram coletados os dados inserem-se no mesmo contexto tectônico da área contaminada junto ao canal do Jurubatuba. Todas estão a oeste da Bacia São Paulo, dentro do Complexo Embu, e entre as zonas de cisalhamento de Caucaia, a norte, e de Cubatão, a sul (Figura 1). As quatro pedreiras visitadas foram denominadas pelas siglas GS1, GS2, GS3 e GS4 e estão localizadas nos municípios de Embu das Artes, Itapecerica da Serra e São Paulo; suas grandes dimensões garantem uma amostragem representativa das fraturas de cada local em que estão situadas. A seguir são descritos os métodos de coleta de dados, de correção do viés de orientação e de caracterização dos grupos de fraturas, 


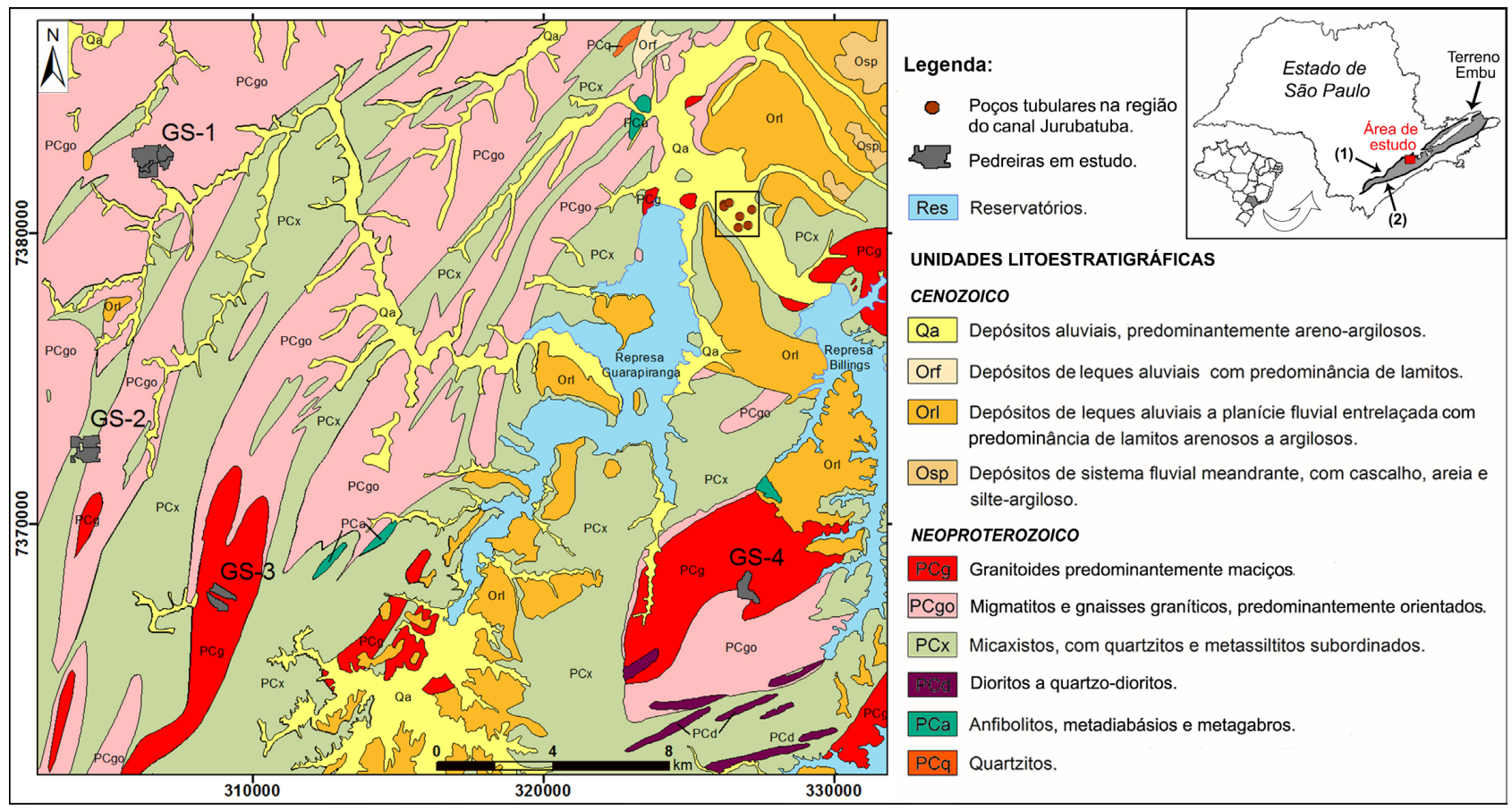

Figura 1. Mapa geológico com localização das pedreiras visitadas e de poços próximos ao canal do Jurubatuba. O mapa geológico é baseado em SABESP/CEPAS-IGc-USP (1994) e o mapa do Estado de São Paulo mostra a área de ocorrência do Terreno Embu, que é delimitado a norte e a sul pelas zonas de cisalhamento de Caucaia (1) e Cubatão (2), respectivamente.

bem como de elaboração do modelo geométrico de fraturas, hierarquizadas em termos de fluxo preferencial.

\section{Coleta de dados em scanlines e em pontos isolados}

O levantamento de dados estruturais nas pedreiras foi realizado ao longo de scanlines (linhas de amostragem ao longo das quais os dados das fraturas foram coletados), em paredes planas, limpas e longas, e em observações pontuais, adequando o método descrito em Rouleau e Gale (1985). As scanlines foram distribuídas e orientadas de forma diversificada de modo que o levantamento fosse representativo do afloramento (Priest, 1993).

Para cada scanline foi preenchida uma planilha contendo seu comprimento e coordenadas inicial e final. Para cada fratura, foram preenchidos os seguintes campos: posição na scanline; fratura simples ou zona de fratura (espessura e número de fraturas); atitude (notação da bússola Clar); direção, caimento de estrias e sentido de movimento; cor e espessura de alteração; preenchimento; morfologia (plana ou ondulada); rugosidade; comprimento; terminação em outra fratura. O campo "observações" foi reservado para: feições indicativas de fluxo (presença de alteração e/ou saídas de água e/ou vegetação); relação com estruturas preexistentes, tais como veios e foliações; padrões de fraturas (em echelon, em flor, conjugadas, anastomosado). Dados estruturais relevantes para a análise tectônica (e.g., slickensides e terminações entre os grupos de fraturas), bem como feições indicativas de fluxo de água subterrânea, foram obtidos também em observações pontuais. Croquis foram elaborados de modo a representar de forma clara as terminações entre as fraturas. $\mathrm{O}$ registro fotográfico foi obtido de forma sistemática e possibilitou realizar observações posteriores.

\section{Correção de viés de amostragem}

$O$ viés de amostragem causado pela orientação relativa entre a linha de amostragem e a atitude média do grupo de fraturas ocorre, principalmente, quando as scanlines não possuem orientações suficientemente variadas e, consequentemente, a proporção das fraturas de diferentes grupos não é adequadamente representada (Terzaghi, 1965). Por exemplo, sondagens verticais favorecem a visualização de fraturas com baixo ângulo de mergulho e não são representativas para as fraturas de mergulhos elevados.

Terzaghi (1965) propôs um método de correção desse viés que se baseia na relação entre o espaçamento aparente (d') e o espaçamento verdadeiro (d) das fraturas de um grupo, causada pelo ângulo $(\alpha)$ entre um furo de sondagem orientado e a orientação das fraturas interceptadas (Figura 2). O número de fraturas presentes ao longo de uma sondagem de comprimento Lé $\mathrm{N} \alpha$, e o corrigido é $\mathrm{N} 90\left(\mathrm{~N} 90=\mathrm{N} \alpha^{*} 1 / \operatorname{sen} \alpha\right)$, que corresponde ao número de fraturas que seriam 


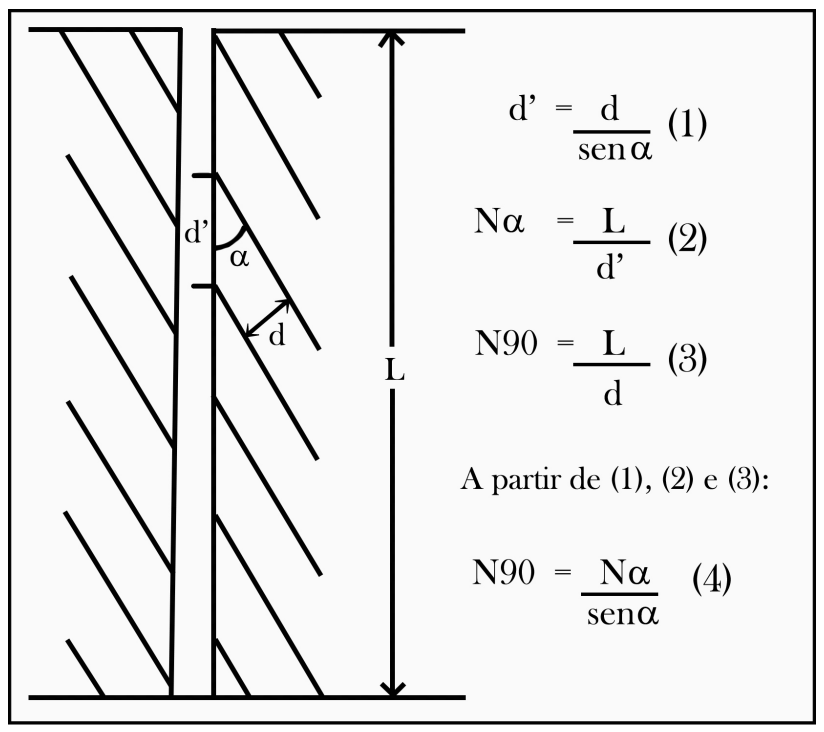

Figura 2. Relação angular entre o espaçamento aparente (d') e o espaçamento verdadeiro (d) de fraturas de um mesmo grupo, e os cálculos envolvidos na correção da densidade de fraturas (modificado de Terzaghi, 1965).

interceptadas, caso a mesma sondagem de comprimento L fosse perpendicular às fraturas. Terzaghi (1965) recomenda desconsiderar fraturas com ângulo $\alpha$ menor que $20^{\circ}$ com a linha de amostragem, devido aos grandes erros que podem causar. Os valores N90 de cada grupo são plotados em um estereograma, obtendo-se em seguida os contornos corrigidos com relação às densidades relativas dos vários grupos de fraturas, auxiliando na identificação dos principais grupos de fraturas presentes nos afloramentos. Neste trabalho as scanlines são linhas horizontais ao longo de afloramentos verticais. Foi utilizada uma adaptação de Pino (2012), que possibilita o uso de softwares para plotagem das densidades corrigidas em estereogramas.

Um cálculo da densidade, para fraturas cujo $\alpha$ é maior do que $20^{\circ}$, foi obtido, para cada scanline, pela soma dos valores de N90 verdadeiro (não multiplicado por 10), para todas as fraturas de um mesmo grupo, e divisão do resultado pelo comprimento da linha de observação; o espaçamento corresponde ao valor inverso da densidade.

\section{Caracterização dos principais grupos de fraturas e elaboração de modelo geométrico}

Os grupos de fraturas (conjunto de fraturas de atitude semelhante que, em geral, distribuem-se de forma concentrada no estereograma) foram identificados através da plotagem dos pólos ou de círculos máximos das fraturas, utilizando o softwares DIPS v.5.1. e OpenStereo v.0.1.2. Modos de propagação de fraturas neoformadas (cisalhamento, extensão ou ambos) foram deduzidos através de relações angulares, em que fraturas conjugadas de cisalhamento e híbridas (estas propagadas simultaneamente por extensão e por cisalhamento) apresentam ângulo $2 \theta$ ao redor de $60^{\circ}$ ou menor que $45^{\circ}$ entre si, respectivamente (Price e Cosgrove, 1990); fraturas neoformadas propagadas apenas por extensão constituem um grupo de fraturas paralelas ao esforço máximo principal $(\sigma 1)$ e podem apresentar "plumas" em suas superfícies. Os modos de propagação, bem como indicadores do sentido do cisalhamento (estrias e feições associadas), permitiram determinar o campo de esforços que gerou cada grupo de fraturas. A idade relativa entre os grupos foi estabelecida com base nas interações entre fraturas, as mais jovens terminam nas mais antigas e tendem a ser mais curtas (Price e Cosgrove, 1990, p. 49-51). Consequentemente, as idades relativas dos campos de esforços, associados a grupos de fraturas específicos, também são estabelecidos. Os dados de espaçamento, comprimento, ocorrência de zonas de fraturas, interação entre grupos de fraturas, bem como a indicação de maior ou menor fluxo de água subterrânea, foram utilizados na elaboração do modelo geométrico.

\section{CONTEXTO GEOLÓGICO}

$\mathrm{Na}$ área contaminada do Jurubatuba e adjacências afloram depósitos aluviais da planície do Canal do Jurubatuba (Quaternário), lamitos arenosos e argilosos de ambiente fluvial da Formação Resende (Oligoceno) e, gnaisses, mica-xistos e granitos maciços do Complexo Embu (Pré-Cambriano) (Figura 1). As pedreiras visitadas são constituídas por gnaisses granitoides (GS1 e GS2) e granitos maciços (GS3 e GS4) do Terreno Embu (Figura 1). Na GS1, o gnaisse é leucocrático, equigranular e relativamente homogêneo, com exceção de algumas porções, de espessura decimétrica, contendo bandas quartzo-feldspáticas e/ou bandas xistosas, ricas em biotita. Veios quartzo-feldspáticos, de granulação média ou grossa, de espessura centimétrica, ocasionalmente de alguns decímetros, e coloração rósea, são comuns, podendo ser paralelos ou oblíquos à foliação. Nas porções de gnaisse homogêneo, a foliação é plano-linear. Na pedreira GS2, o gnaisse é muito homogêneo e de composição granitoide, leucocrático, inequigranular médio, com megacristais esparsos (1 a $2 \mathrm{~cm}$ ) de feldspato branco e frequentes veios, em geral paralelos à foliação, centimétricos, quartzo-feldspáticos, brancos. Nas pedreiras GS3 e GS4 ocorre granito cinza claro, leucocrático, equigranular médio, com enclaves leucocráticos a mesocráticos, centimétricos a decimétricos, de cor cinza médio a escuro, além de ocasionais veios quartzo-feldspáticos, centimétricos, brancos e de granulação grossa.

As zonas de cisalhamento Taxaquara e Caucaia-Rio Jaguari são as estruturas mais marcantes da região e delimitam o Terreno Embu a norte e a sul, respectivamente, com idades de 605 a $520 \mathrm{Ma}$ (Heilbron et al., 2004). A deformação rúptil mais importante data do Paleógeno e corresponde 
às falhas que fazem parte do Sistema de Riftes da Serra do Mar (Almeida, 1976), renomeado como Rift Continental do Sudeste do Brasil (RCSB) (Riccomini, 1989), ao qual a deposição da Bacia São Paulo está associada. As antigas zonas de cisalhamento foram reativadas durante o Paleógeno (Riccomini, 1989), resultando num hemigráben de direção ENE, basculado para NNW, com borda norte retilínea e controlada pelas zonas de cisalhamento Taxaquara-Jaguari, e borda sul irregular, onde as unidades da Bacia repousam sobre rochas do Terreno Embu (Riccomini e Coimbra, 1992). Após a formação das bacias do RCSB, eventos tectônicos, do Neógeno ao Holoceno, deformaram as suas unidades sedimentares (Riccomini et al., 2004).

\section{RESULTADOS}

\section{Caracterização dos grupos de fraturas}

Os grupos de fraturas identificados, contrastantes para as pedreiras GS-1 e GS-2 (Figuras 3 e 4) e semelhantes para as pedreiras GS-3 e GS-4 (Figuras 5 e 6 ), foram numerados de acordo com a sua abundância relativa. O grupo 1, o mais frequente na GS-1 e GS3, apresenta direções N5-65W e mergulho subvertical (Tabela 1). Forma conspícuas zonas de fraturas (Figura 7 e 8), que, na GS3, concentram-se no intervalo N30-40W e alojam diques (Figura 8) de espessura centimétrica a até $40 \mathrm{~cm}$. A composição mineralógica original
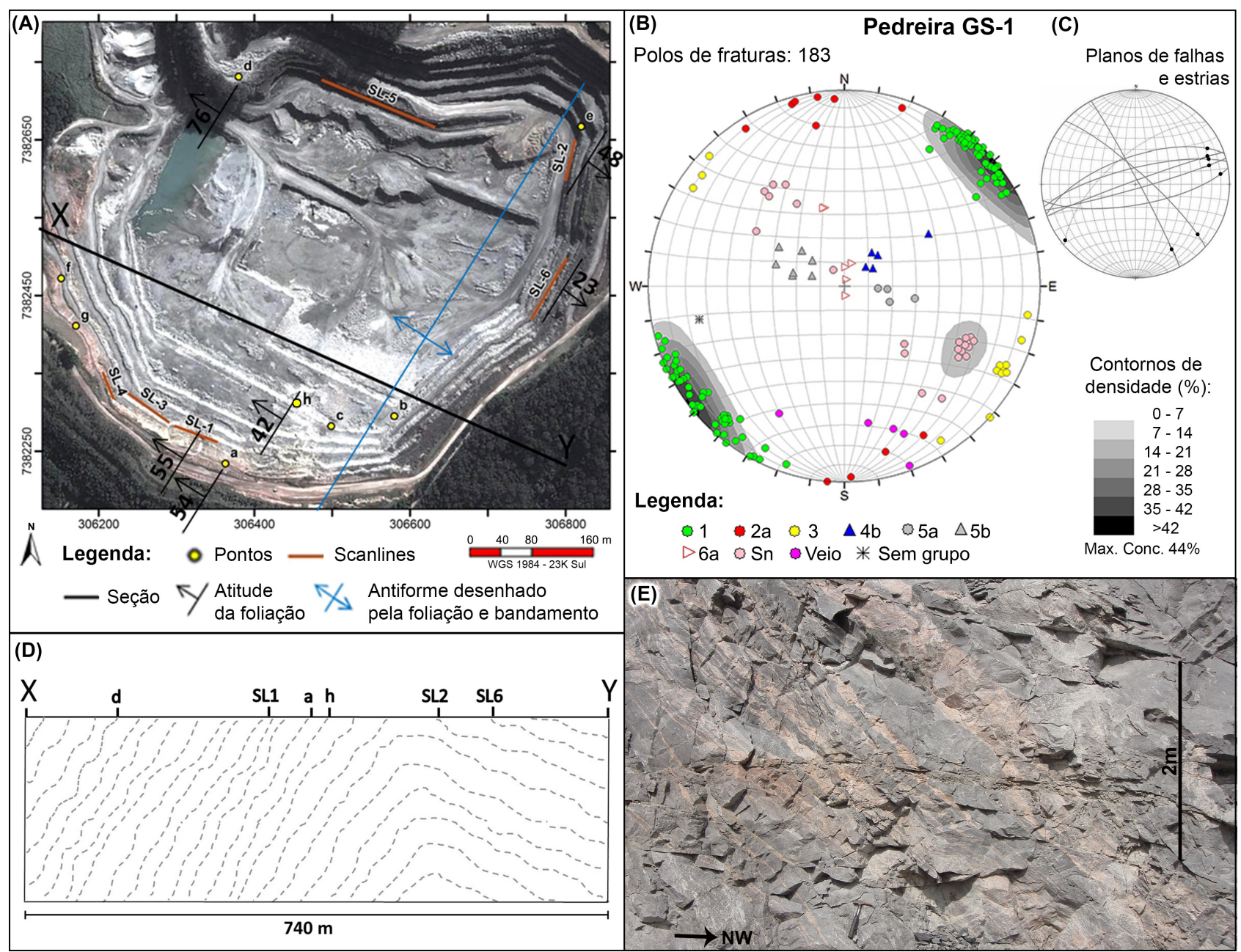

Figura 3. (A) Planta da pedreira GS1 com localização de scanlines (SL) e pontos onde os dados estruturais foram levantados. (B) Cada grupo de fratura é representado por uma cor no estereograma de projeção polar, cujos contornos de densidade foram corrigidos com relação ao viés de amostragem. "Sn" refere-se a fraturas paralelas à foliação (21 medidas), e "Veio" refere-se a fraturas paralelas a veios (5 medidas). (C) Estereograma de grandes círculos representa falhas com suas estrias (pontos nos grandes círculos). (D) Seção XY, representada em (A), mostrando o antiforme desenhado pela foliação e bandamento. (E) Bandamento gnáissico observado no ponto c. Em (B) e (C), os dados foram projetados no Hemisfério Inferior, sobre o diagrama de Igual Área. 

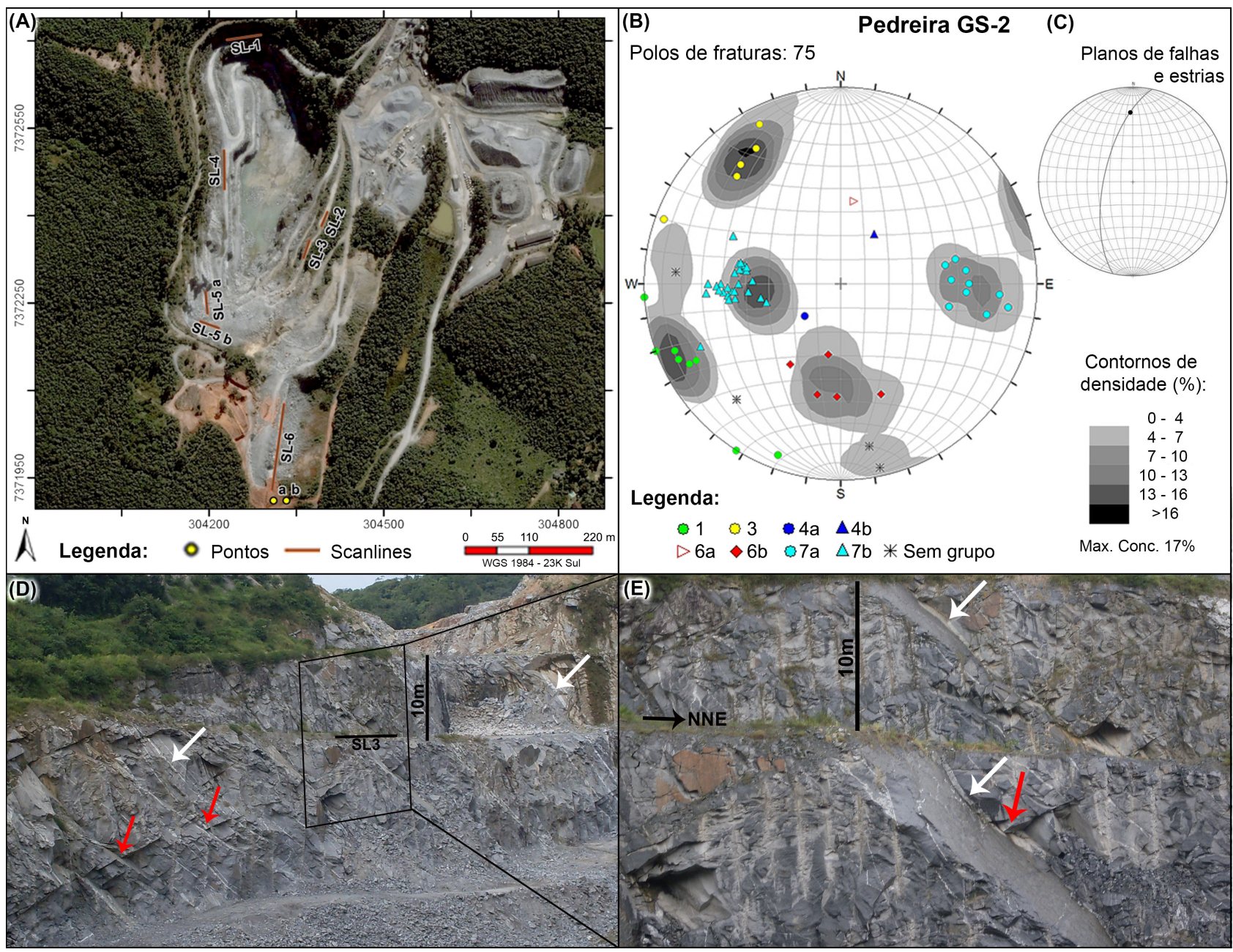

Figura 4. (A) Planta da pedreira GS2 com localização de scanlines(SL) e pontos onde os dados estruturais foram levantados. (B) e (C) estereogramas representando todas as fraturas (e contornos corrigidos com relação ao viés de amostragem) e as falhas com suas estrias, respectivamente. (D) e (E) parede da SL3, mostrando fraturas do grupo $6 \mathrm{~b}$ que terminam nas fraturas mais contínuas do grupo 6 a (flechas vermelhas); as fraturas 6a são paralelas aos veios (flechas brancas). Em (B) e (C), os dados foram projetados no Hemisfério Inferior, sobre o diagrama de Igual Área.

é desconhecida, e a intensa alteração, que produziu apenas argilominerais, indica origem diversa da do granito.

Existe um grande número de fraturas de direção geral E-W (GS3 e GS4) (Figura 9), podendo variar para N60-75E (GS1 e GS4), que, por apresentar intervalos de mergulhos distintos, foi subdivido nos grupos: 2a com mergulho subvertical $\left(80^{\circ}\right.$ a $\left.90^{\circ}\right)$ para sul (GS3 e GS4) ou norte (GS3); $2 \mathbf{b}$ com mergulho entre 75 e 65 para sul; 2c com mergulho entre 80 e 65 para norte; $2 \mathbf{d}$ com mergulho entre 65 e 45 para sul. As fraturas N60-75E com mergulho de 60 a $90^{\circ}$, na GS1, são em parte subparalelas a veios. Por este motivo, a análise da orientação dos esforços e do regime tectônico das fraturas EW é feita apenas com base nos dados da GS3 e GS4, onde não são condicionadas por descontinuidades anteriores.
O grupo 3 ocorre de forma isolada e é composto por fraturas com direção $\mathrm{NE}$ e mergulho entre 60 e $90^{\circ}$ para NW ou SE, e é melhor representado na GS-3, apesar de ter sido identificado apenas localmente (Figura 10).

A foliação NE dobrada do gnaisse da GS1 (Figura 3) foi reativada durante a deformação rúptil, junto com os veios de atitudes variadas. Isto explica a diversidade de mergulhos das fraturas NE, em parte relacionáveis ao grupo 3. A foliação no GS1, com direção predominante N30-40E, desenha um antiforme de dobra cilíndrica assimétrica, com eixo N30-40E sub-horizontal (Figura 3); o flanco leste apresenta mergulhos de 28 a $48^{\circ}$ para SE, e o flanco a oeste, 35 a $76^{\circ}$ para NW. Fraturas NE paralelas a veios félsicos de atitude N70-80E/65-90NW são comuns.

Fraturas com mergulho inferior ou ao redor de $30^{\circ}$ ocorrem em menor quantidade que as subverticais, em parte porque 
Tabela 1. Síntese da descrição das características geométricas dos grupos de fraturas.

\begin{tabular}{|c|c|c|c|}
\hline Grupo & Direção & Mergulho & $\begin{array}{c}\text { Espaçamento entre fraturas }\left({ }^{\star}\right) \text { e dentro de zona de fratura }(* *) \\
\text { Morfologia; Comprimento; [sigla da pedreira] } \\
\text { e número de fraturas por pedreira }\end{array}$ \\
\hline 1 & $\begin{array}{l}\text { N15-65W (GS1) } \\
\text { N5-60W (GS2) } \\
\text { N10-55W (GS3) } \\
\text { N5-50W (GS4) }\end{array}$ & $70-90$ para NE ou SW & $\begin{array}{l}\text { Espaçamento: *2,4 a } 13,8 \mathrm{~m},{ }^{*} 0,07 \text { a } 0,54 \mathrm{~m} \text { (11 zonas) } \\
\text { Morfologia: planas a muito planas } \\
\text { Comprimento: pelo menos } 60-70 \mathrm{~m} \text { (GS1, GS3), pelo menos } \\
\text { métricas (GS2, GS4) } \\
\text { [GS1] 110, [GS2] 8, [GS3] 141, [GS4] } 22\end{array}$ \\
\hline $2 a$ & $\begin{array}{l}\text { N60-90E (GS1) } \\
\text { N75-85W (GS3) } \\
\text { N85E-N80W e } \\
\text { N60-75E (GS4) }\end{array}$ & $80-90$ para $\mathrm{N}$ ou $\mathrm{S}$ & $\begin{array}{l}\text { Espaçamento: *2,4 a } 31,6 \mathrm{~m},{ }^{* *} 0,19 \text { a } 0,80 \mathrm{~m} \text { (5 zonas) } \\
\text { Morfologia: planas (Figura } 9 \mathrm{~A} \text { e B). } \\
\text { Comprimento: métrico a decamétrico } \\
\text { [GS1] 11, [GS3] 36, [GS4] } 47\end{array}$ \\
\hline $2 b$ & EW-N75W (GS3) & $80-65 /$ Norte & $\begin{array}{l}\left.\text { *1,7 a } 16,9 \mathrm{~m},{ }^{* *} 0,20 \mathrm{~m} \text { ( } 2 \text { zonas }\right) \\
\text { Morfologia: planas } \\
\text { Comprimento: métrico a decamétrico } \\
\text { [GS3] } 26\end{array}$ \\
\hline 2c & N75-85E (GS3,GS4) & 75-65/Sul & $\begin{array}{l}\text { Espaçamento: *2,4 a } 31,6 \mathrm{~m},{ }^{* *} 0,19 \text { a } 0,80 \mathrm{~m} \text { (5 zonas) } \\
\text { Morfologia: planas (Figura } 9 \mathrm{~A} \text { e B). } \\
\text { Comprimento: métrico a decamétrico } \\
\text { [GS3] 4, [GS4] } 14\end{array}$ \\
\hline $2 d$ & $\begin{array}{l}\text { N75-85W (GS3) } \\
\text { N60-80E (GS4) }\end{array}$ & 65-45/Sul & $\begin{array}{l}\text { *3,7 a } 37 \mathrm{~m} \text {, não formam zonas de fraturas } \\
\text { Morfologia: planas a suavemente curvas } \\
\text { Comprimento: métrico a decamétrico } \\
\text { [GS3] 40, [GS4] } 8\end{array}$ \\
\hline 3 & $\begin{array}{l}\text { N10-40E (GS1) } \\
\text { N20-45E (GS3) } \\
\text { N60E (GS4) }\end{array}$ & $\begin{array}{l}\text { NW ou SE >75 (GS3) } \\
>60^{\circ} \text { (GS2) }\end{array}$ & $\begin{array}{l}\text { Espaçamento: *> } 28 \mathrm{~m} \text { medido apenas na GS3; ocorrem } \\
\text { isoladamente } \\
\text { Morfologia: suavemente onduladas a onduladas } \\
\text { Comprimento: métrico a decamétrico } \\
\text { Na GS1 são comumente paralelas à foliação } \\
\text { [GS1] 13, [GS2] 5, [GS3] 20, [GS4] } 3\end{array}$ \\
\hline $4 a$ & N0-35W (GS3,GS4) & 10-35/NE & \multirow{2}{*}{$\begin{array}{l}\text { Espaçamento: ocorrem de forma ocasional, por vezes sob a } \\
\text { forma de zona de fraturas com espaçamento centimétrico a } \\
\text { métrico } \\
\text { Morfologia: planas a onduladas } \\
\text { Comprimento mínimo varia de } 3 \text { a } 12 \mathrm{~m} \\
\text { [GS1] 5, [GS2] 1, [GS3] 12, [GS4] } 7\end{array}$} \\
\hline $4 b$ & $\begin{array}{l}\text { N15-60W } \\
\text { (GS1,GS3,GS4) }\end{array}$ & $10-25 / \mathrm{SW}$ & \\
\hline $5 a$ & $\begin{array}{l}\text { N10-40E } \\
\text { (GS1,GS3,GS4) }\end{array}$ & $15-35 N W$ & $\begin{array}{l}\text { Morfologia: onduladas em zonas ocasionais com espaçamento } \\
\text { decimétrico } \\
\text { Comprimento mínimo de } 2 \text { a } 5 \mathrm{~m} \\
\text { [GS1] 4, [GS3] 5, [GS4] } 3\end{array}$ \\
\hline $5 b$ & N15-45E (GS1) & 15-35/SE & $\begin{array}{l}\text { Espaçamento: zonas de fraturas com espaçamento decimétrico, } \\
\text { contendo algumas faixas com espaçamento centimétrico } \\
\text { Comprimento: > 50 m, quando subparalelas à foliação } \\
\text { [GS1] } 7,[\mathrm{GS} 3] 5, \text { [GS4] } 3\end{array}$ \\
\hline $6 a$ & $\begin{array}{l}\text { N75-80W (GS1) } \\
\text { N60E-N85W (GS4) }\end{array}$ & $\sim 35 /$ Sul & $\begin{array}{l}\text { *3,7 a } 37 \mathrm{~m} \text {, não formam zonas de fraturas } \\
\text { Morfologia: planas a suavemente curvas } \\
\text { Comprimento: métrico a decamétrico } \\
\text { [GS1] 6, [GS2] 1, [GS3] 1, [GS4] } 12\end{array}$ \\
\hline $6 b$ & $\begin{array}{l}\text { N80-90W (GS2) } \\
\text { N75-80E (GS4) }\end{array}$ & $30-50 /$ Norte & $\begin{array}{l}\text { *8,8 a } 34,5 \mathrm{~m},{ }^{* *} \text { decimétrico (GS2 e GS4) } \\
\text { [GS2] 5, [GS3] 3, [GS4] } 2\end{array}$ \\
\hline $7 a$ & N0-15W(GS2) & $30-60 \mathrm{E}$ & $\begin{array}{l}\text { Comprimento métrico a decamétrico } \\
\text { 7a [GS2] } 10\end{array}$ \\
\hline $7 b$ & NS (GS2) & $45-75 W$ & $\begin{array}{l}\text { Comprimento métrico a decamétrico } \\
\text { 7b [GS2] } 31\end{array}$ \\
\hline
\end{tabular}

as scanlines são horizontais e, portanto, não favorecem a sua medição. Observa-se dispersão mais acentuada destas fraturas na GS1, e isto é atribuído ao fato de parte destas fraturas terem se propagado paralelamente à foliação dobrada do gnaisse (Figura 3) e, mais subordinadamente, aos veios. Foi possível identificar a existência dos seguintes grupos: grupos 4a e 4b, nas pedreiras GS2, GS3 e GS4, com direções no intervalo N35W-NS e mergulhos de 10 a $30^{\circ}$ para $\mathrm{NE}(4 \mathrm{a})$, ou 20 a $25^{\circ}$ para $\mathrm{SW}(4 \mathrm{~b})$; grupos $\mathbf{5 a}$ e 5b, nas pedreiras GS1, GS3 e GS4, de direções 

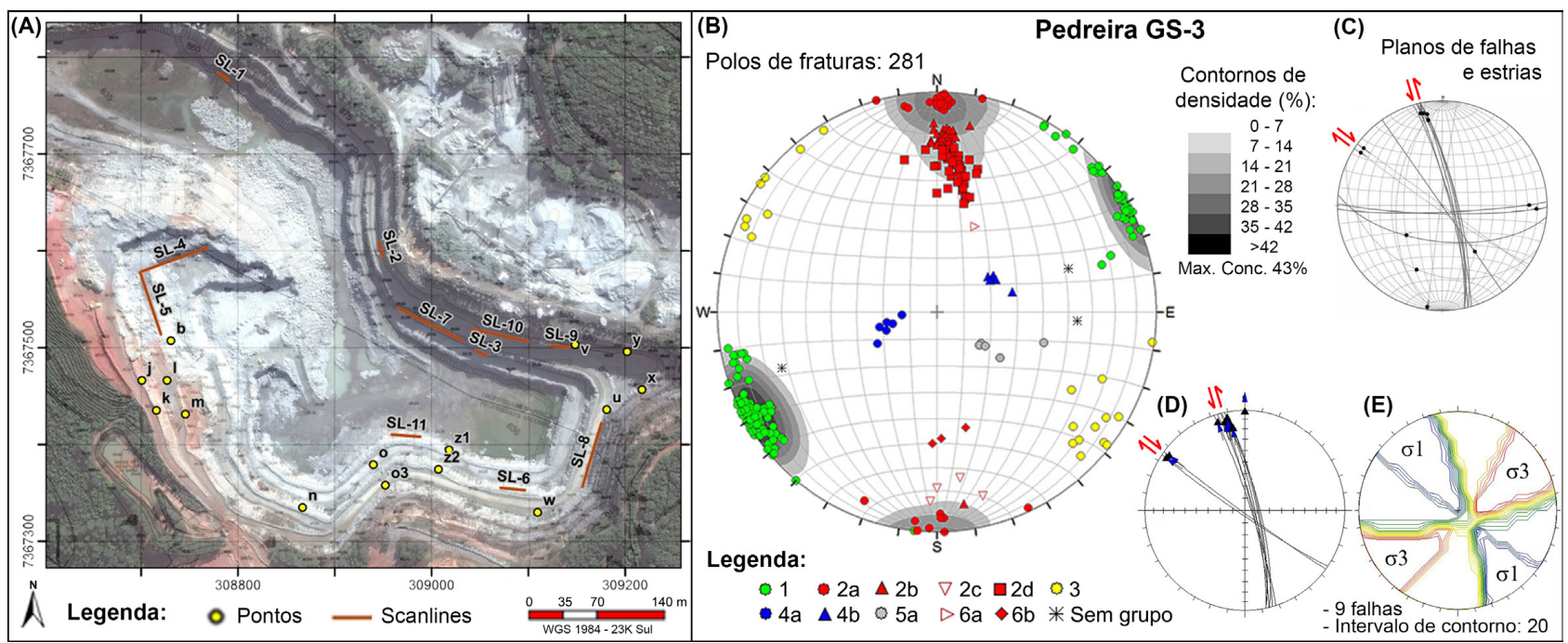

Figura 5. (A) Planta da pedreira GS3 com localização de scanlines (SL) e pontos onde os dados estruturais foram levantados. (B) Cada grupo de fratura é representado por uma cor no estereograma de projeção polar, cujos contornos de densidade foram corrigidos com relação ao viés de amostragem. (C) O estereograma de grandes círculos representa falhas com suas estrias e sentidos de movimento. (D) Falhas transcorrentes do grupo 1 com indicação de movimento. (E) Diagrama dos diedros retos (método de Angelier e Mechler, 1977) com a orientação dos esforços $\sigma 1$ e $\sigma 3$ obtidos através do Stereo32 para as falhas plotadas em (D). Em (B) e (C), os dados foram projetados no Hemisfério Inferior, sobre o diagrama de Igual Área.
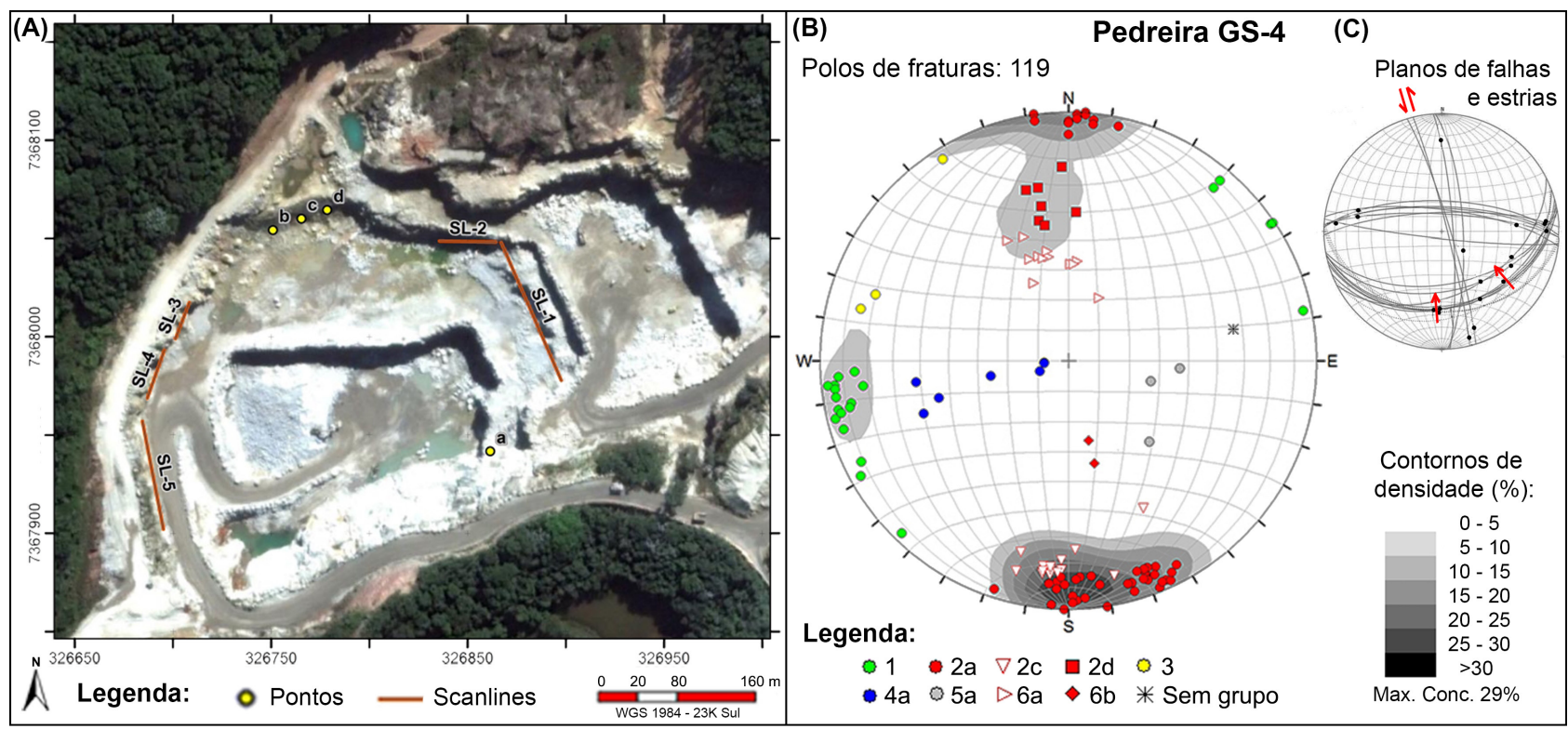

Figura 6. (A) Planta da pedreira GS4 com localização de scanlines (SL) e pontos onde os dados estruturais foram levantados. (B) Cada grupo de fratura é representado por uma cor no estereograma de projeção polar, cujos contornos de densidade foram corrigidos com relação ao viés de amostragem. (C) O estereograma de grandes círculos representa falhas com suas estrias e sentidos de movimento. Em (B) e (C), os dados foram projetados no Hemisfério Inferior, sobre o diagrama de Igual Área.

predominantemente no intervalo N15E-N45E e mergulhos entre 20 e $30^{\circ}$ para NW (5a) ou 15 a $35^{\circ}$ para SE (5b); grupos 6a e 6b, de direção aproximada EW (N65E a N80W), com mergulho ao redor de 25 a $40^{\circ}$ para sul (6a, na GS4) ou de 30 a 50 para norte (6b, na GS2), respectivamente.
Na parede da porção leste da GS1, as fraturas do grupo $\mathbf{5 b}$ (N15-45E/15-35SE) são subparalelas à foliação e destacam-se pela grande continuidade (Tabela 1, Figura 11); já o grupo 5a (N15E-N45E/20-30NW) ocorre muito ocasionalmente, assim como os grupos $4 \mathbf{a}$ e $4 \mathbf{b}$. 


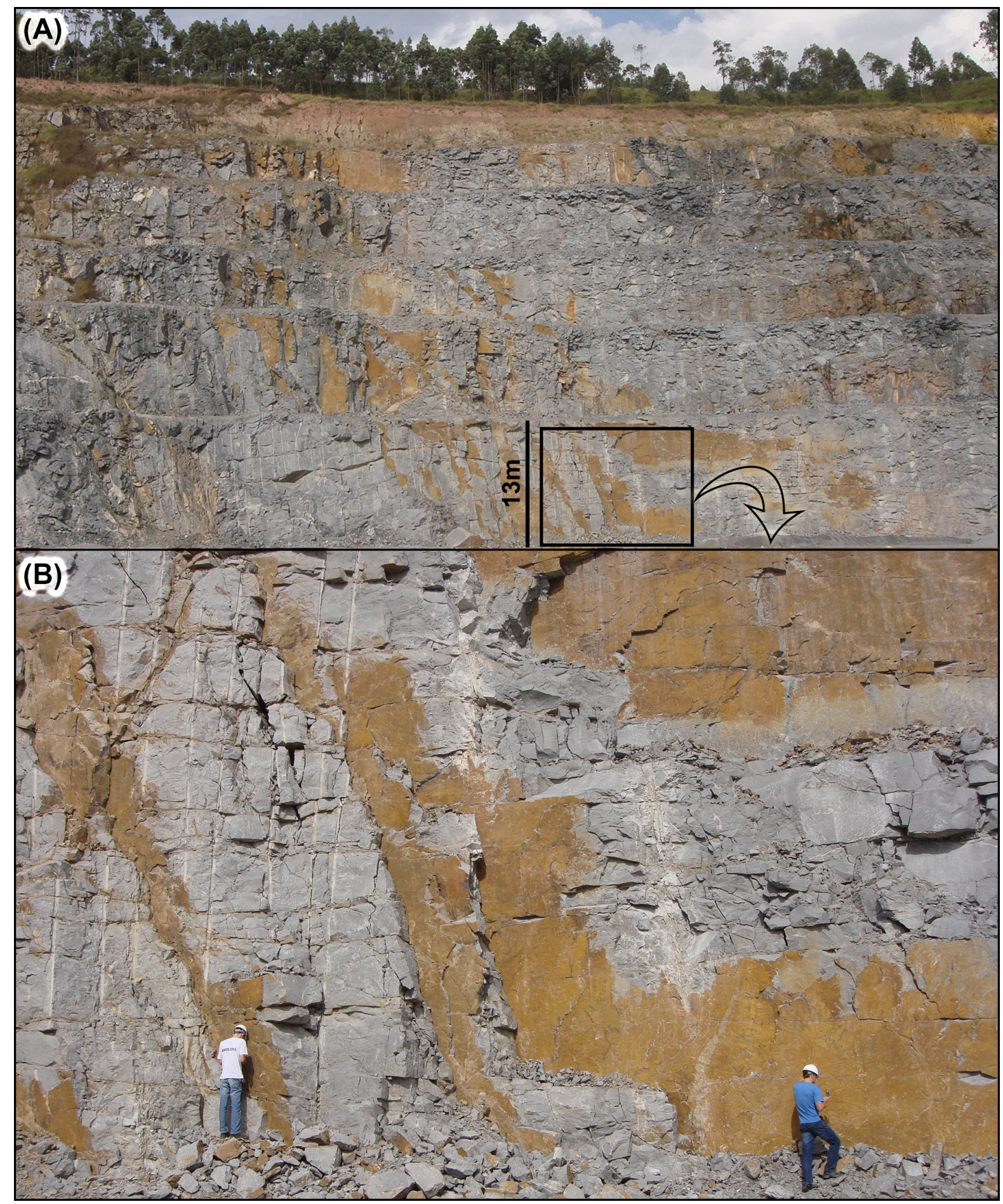

Figura 7. GS1. (A) Conspícuas zonas de fraturas planas do grupo 1 que passam de uma bancada para a outra, seccionando pelo menos seis bancadas e totalizando um comprimento mínimo de cerca de $70 \mathrm{~m}$. (B) Detalhe de (A).

Exclusivos da pedreira GS2, os grupos de fraturas 7a e 7b (Figura 4) apresentam direção N-S e ângulo de mergulho predominantemente entre $45^{\circ}$ e $55^{\circ}$ para oeste ( 7 a ) e $40^{\circ}$ e $55^{\circ}$ para leste (7b). As fraturas do grupo 7a são subparalelas às atitudes da foliação do granito-gnaisse desta pedreira e comumente ocorrem no contato entre veio e rocha (Figura 4). Podem conter estrias, com caimento de $27^{\circ}$ e movimento sinistral indicado por degraus no preenchimento de quartzo presente na superfície de falha. Tal movimento é consistente com evento transcorrente que gerou o grupo $1\left(\sigma_{1}\right.$ de direção 


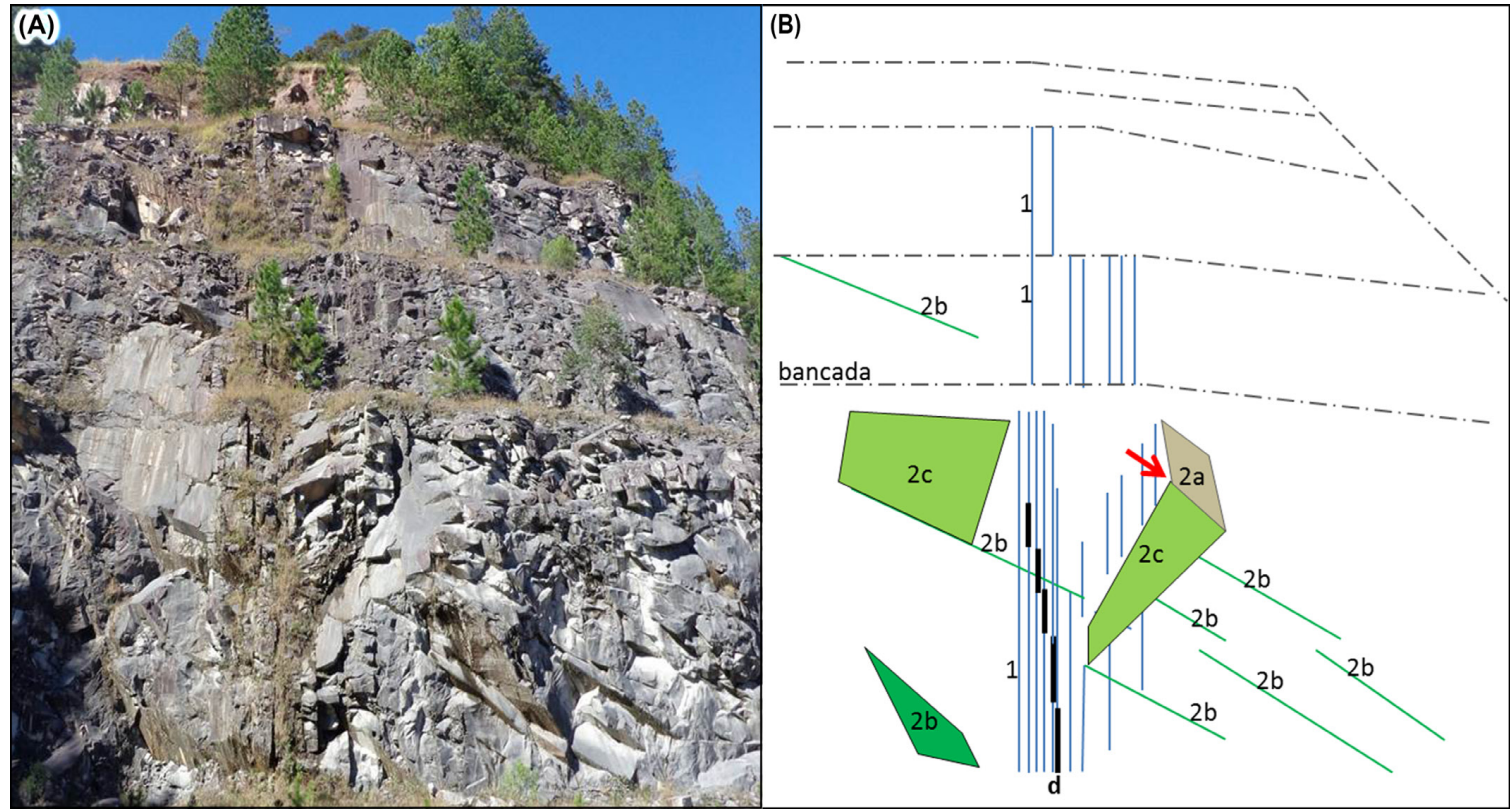

Figura 8. GS-3, ponto x na figura 5. (B) Representação esquemática de (A). Dique máfico em echelon (d) de espessura centimétrica foi observado na zona de fraturas contínuas e subverticais do grupo 1 (atitude média 57/88). Grande parte das fraturas desta zona, acompanhadas por alteração e por vegetação, terminam em fratura do grupo $2 c$ (esta é mais antiga) à direita do dique. A fratura 2c, na sua porção superior, passa para fratura do grupo 2a (ponto de inflexão indicado por flecha). As atitudes são dadas pela notação da bússola Clar.

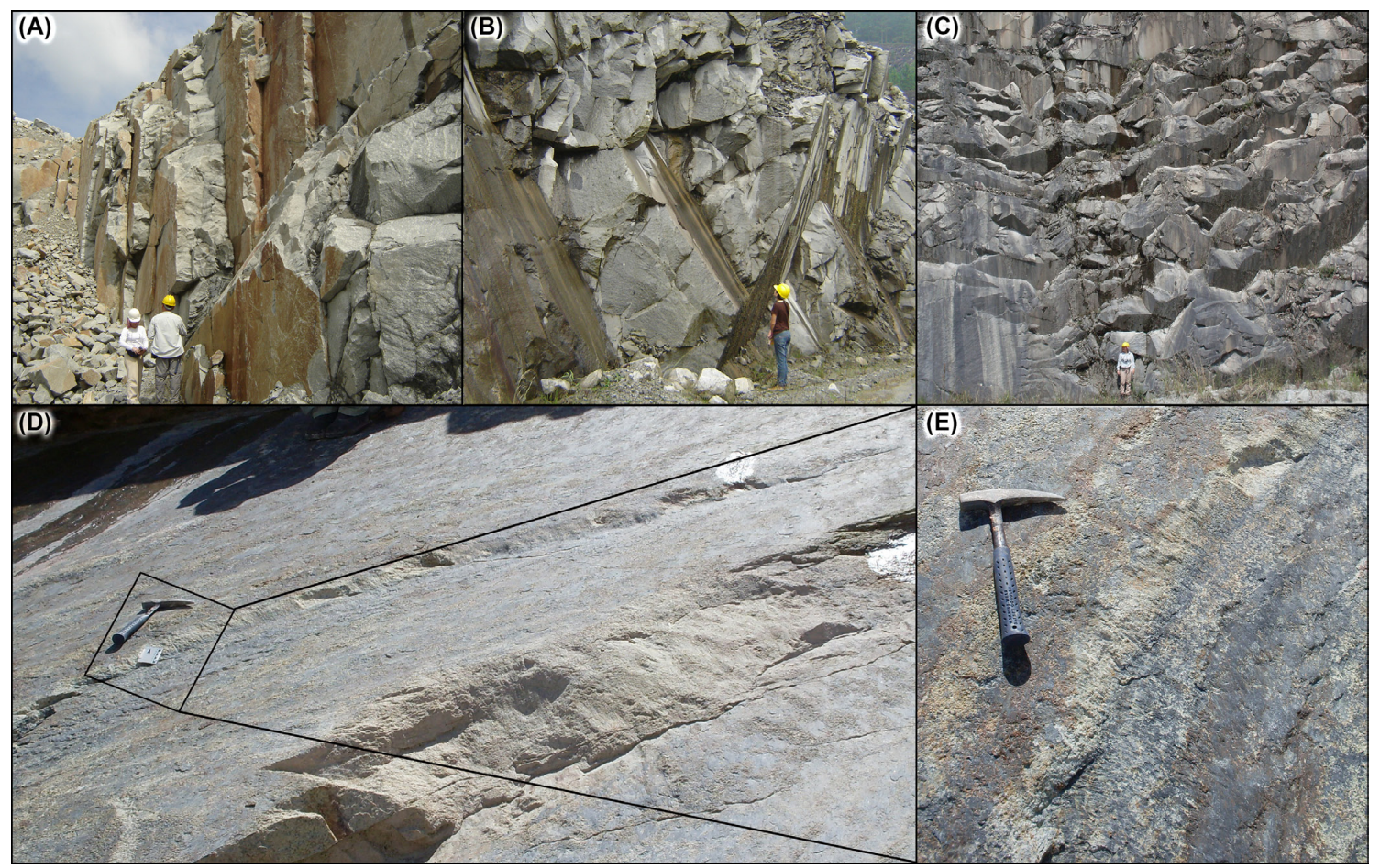

Figura 9. Fraturas de direção geral E-W (GS3 e GS4), podendo variar para N60-75E (GS1 e GS4). (A) Zona de fratura do grupo 2 a com mergulho subvertical $\left(80^{\circ}\right.$ a $\left.90^{\circ}\right)$ para sul (atitude média 180/86, SL4) e fratura 196/55 do grupo 2 d. (B) Grupos $2 \mathrm{~b}$ com mergulho entre 75 e 65 para sul e 2c com mergulho entre 80 e 65 para norte, indicando regime de falhas normais (atitudes médias 2/75 e 185/60, SL3). (C) Zona de fratura do grupo 2b (atitude média 185/70, ponto W). (D) Fraturas do grupo 6 a com mergulho ao redor de $35^{\circ}$ para sul (GS4) e estrias no rumo do mergulho. (E) As estrias, nas rampas que conectam as fraturas $6 a$, indicam movimento de falha inversa. As atitudes são dadas pela notação da bússola Clar. 


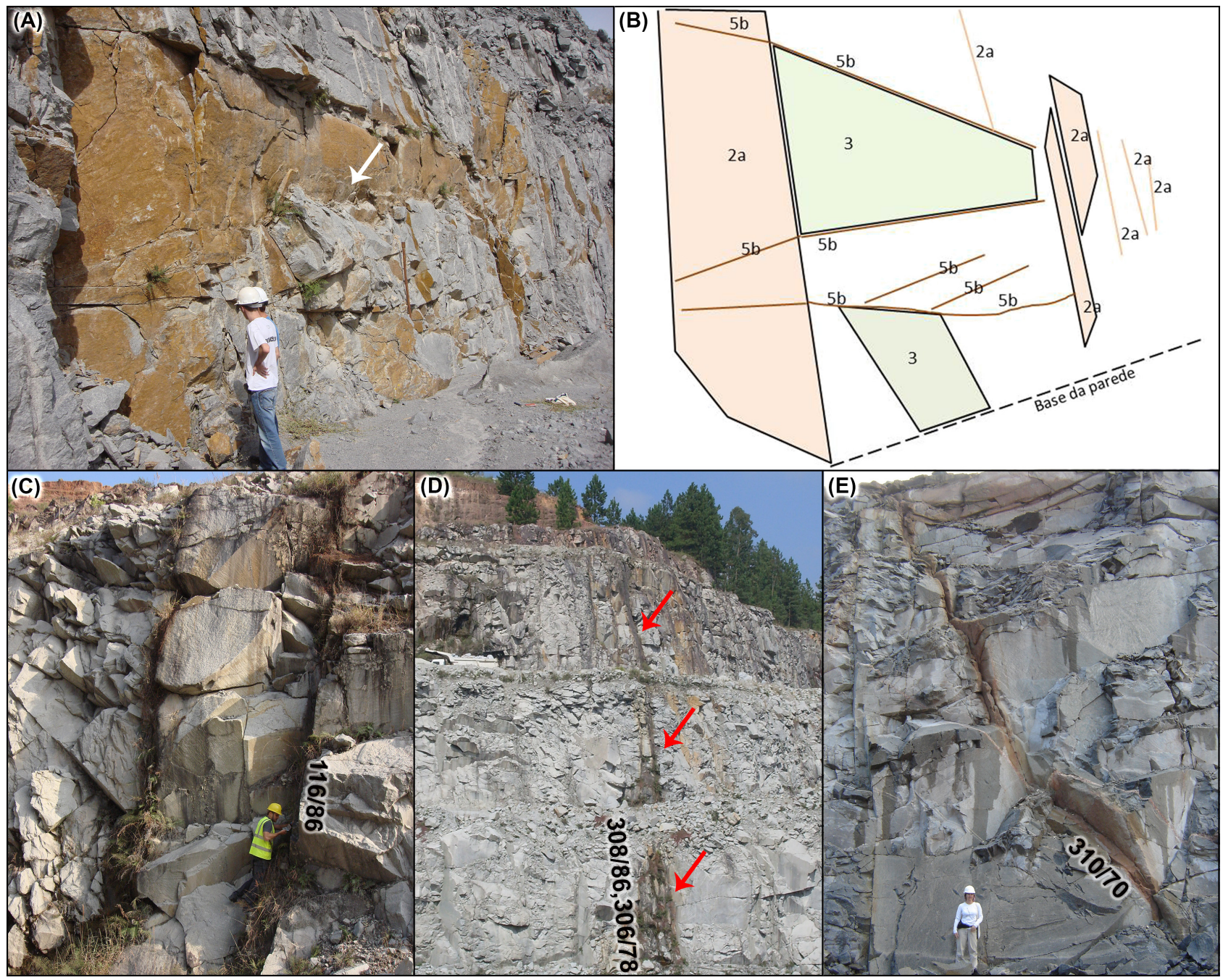

Figura 10. (A) GS1. Fraturas do grupo 3 (312/90), do grupo 2a (358/87) e do grupo 5b (130/23). A fratura do grupo 3 , ao se aproximar de fratura do grupo $5 b$, sofre encurvamento (flecha), indicando que o evento do grupo $5 b$ é mais antigo. (B) Desenho esquemático de (A). (C, D e E) GS3. Todas as fraturas do grupo 3 mostram alteração (cor ocre), que ocorre desde o topo até a base da pedreira (flechas). As atitudes são dadas pela notação da bússola Clar.

NW), As fraturas do grupo $7 \mathrm{~b}$ são perpendiculares ao $7 \mathrm{a}$ e frequentemente terminam nestas últimas, indicando que $7 \mathrm{~b}$ é mais jovem. A ortogonalidade entre estes grupos sugere que a propagação do mais novo foi controlada pelo mais antigo; no entanto, o mecanismo que proporcionou esta relação é desconhecido.

O espaçamento foi calculado para os grupos $1,2 \mathrm{a}, 2 \mathrm{~b}$, $2 \mathrm{c}, 2 \mathrm{~d}, 3$, 6a e $6 \mathrm{~b}$, pois são os que apresentam ao menos duas fraturas em pelo menos uma scanline horizontal. Pelo fato das scanlines horizontais proporcionarem uma baixa amostragem das fraturas do grupo $5 \mathrm{~b}$, seu espaçamento, na pedreira GS-1, foi obtido por contagem ao longo de 15 linhas verticais observadas em fotos próximas ao ponto $\mathrm{b}$ (Figuras 3A e 11C) e às scanlines SL-2 e SL-6. Trata-se de espaçamento aparente, mas relativamente próximo do real, já que o mergulho das fraturas é baixo (em torno de $20^{\circ}$ ).
Considerando todos os grupos de fraturas, os valores de espaçamento variam de 1,7 a 37,0 m (Tabela 1) e ajustam-se a uma distribuição logarítmica (Figura 11A) e a mediana e os quartis $(25 \%$ e $75 \%)$, mais representativos para esse tipo de distribuição, são, respectivamente, 8,8, 4,7 e 15,3 m. Já os espaçamentos das fraturas do grupo $5 \mathrm{~b}$ apresentam distribuição linear (Figura 11B), com média de $2 \mathrm{~m}$. Tomando como referência os valores da mediana e dos quartis, bem como a quantidade de scanlines em que cada grupo teve seu espaçamento calculado, conclui-se que os grupos em ordem crescente de densidade são: NE/vertical (grupo 3), $\mathrm{E}-\mathrm{W} /$ baixo a médio para norte (grupo 6b), E-W/médio a baixo para sul (grupos $2 \mathrm{~d}$ e $6 \mathrm{a}$ ), E-W/médio a elevado para sul (grupos 2b e 2d), E-W/vertical (grupo 2) e NW/vertical (grupo 3). O grupo 1 é o que apresenta a maior quantidade de zonas de fraturas e, dentro destas, os menores espaçamentos. 


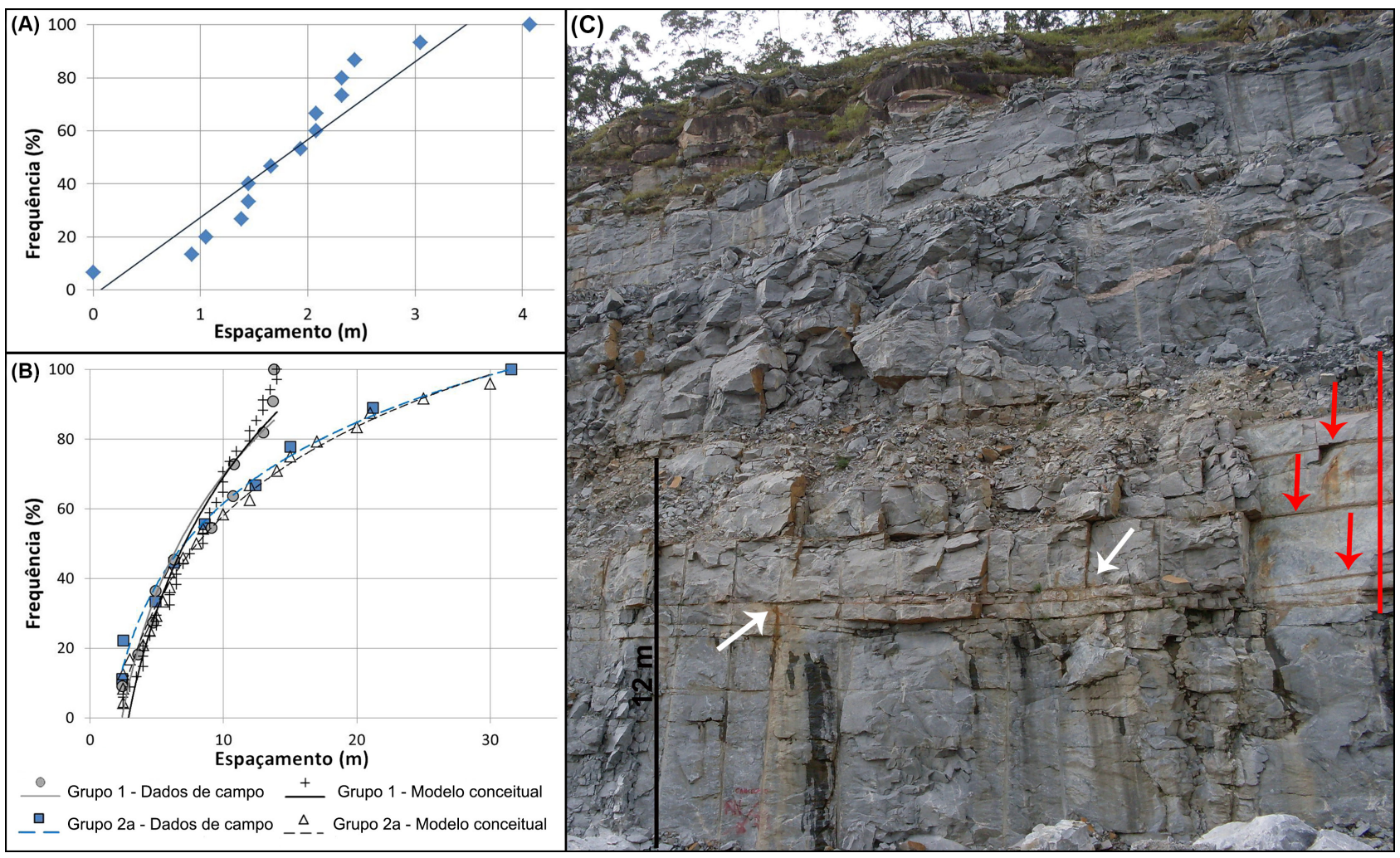

Figura 11. (A) Frequência acumulada dos valores de espaçamento (m), com distribuição linear (média de 2 m) para as fraturas do grupo 5b da GS-1. (B) Comparação entre as frequências acumuladas dos valores de espaçamento obtidos em campo (distribuição logarítmica) e utilizados no modelo geométrico para as fraturas dos grupos 1 e 2 a. (C) No ponto b da GS-1 destacam-se fraturas do grupo 5b, com alteração evidente (cor ocre, flechas verticais) na porção central da foto, e fraturas do grupo 1, terminando nas fraturas do grupo 5b (flechas inclinadas). Maior alteração ao longo de fraturas do grupo $5 \mathrm{~b}$ concentra-se na parte central da foto (barra vertical à direita das flechas verticais).

É seguido pelos grupos 2a, com os espaçamentos um pouco maiores, e $2 \mathrm{~b}+2 \mathrm{~d}$, com apenas uma zona com espaçamento interno semelhante ao 2a (Tabela 1).

\section{Análise tectônica}

A análise tectônica consistiu em identificar os modos de propagação e os campos de esforços geradores dos principais grupos de fraturas, tendo como base os padrões geométricos de fraturas (ex., fraturas conjugadas ou fraturas paralelas) e feições presentes nas superfícies das fraturas, tais como plumas e estrias. Desta forma, foram identificados os eventos de deformação rúptil, com campos de esforços e regimes tectônicos específicos. A idade relativa entre tais eventos foi estabelecida com base na terminação de fraturas (ver item Métodos), sendo apresentada, de forma sucinta, na Tabela 2. A seguir, os eventos e suas relações de superposição são descritos do mais antigo para o mais jovem.

O evento tectônico gerador dos grupos $\mathbf{5 a}$ e $\mathbf{5 b}$ (N10-40E $/ 15^{\circ}-35^{\circ}$ para NW ou SE) é mais importante na GS1, e caracteriza-se por reativar a foliação, sendo, assim, difícil determinar a orientação dos esforços deste evento.
Trata-se do evento mais antigo, sendo que fraturas dos grupos 3 e 1 terminam em fraturas do grupo $5 \mathrm{~b}$ (Figura 10A e 11C).

O grupo 3, de direção NE e com mergulhos predominantemente subverticais (Figura 10), ocorre de forma muito subordinada e não foram observadas feições que permitam indicar qual foi seu modo de propagação, se extensional ou de cisalhamento. Estrias com caimento de $6^{\circ} \mathrm{em}$ fratura N50E podem ter sido tanto sincrônicas à geração da fratura, neste caso em regime transcorrente, como produto de reativação. Fraturas do grupo 4 são mais jovens, pois terminam nas do grupo 3 nas pedreiras GS1 e GS3.

As fraturas dos grupos $4 \mathbf{a}$ e $4 \mathbf{b}\left(\mathrm{N} 0-40 \mathrm{~W} / 10^{\circ}-30^{\circ}\right.$ para $\mathrm{NE}$ ou SW) são prováveis fraturas conjugadas geradas por regime tectônico compressivo com $\sigma 1$ horizontal de direção ao redor de N70E. Fraturas dos grupos $2 \mathrm{a}$ e $2 \mathrm{~b}$ terminam nas fraturas do grupo 4, nas pedreiras GS3 e GS4.

Os grupo 2b e 2c formam um nítido par de fraturas conjugadas (falhas normais, Figura 9B), pois apresentem a mesma direção (EW) e mergulhos de $60^{\circ}$ a $75^{\circ}$ em sentidos opostos; o ângulo $2 \theta$ entre $30^{\circ}$ e $50^{\circ}$ indica que a propagação foi híbrida. Foram geradas em regime extensional com $\sigma_{3}$ de direção N-S e $\sigma_{1}$ vertical. A superfície de tais fraturas pode 
Tabela 2. Síntese da Análise Tectônica com os eventos ordenados do mais antigo (base) para o mais novo (topo).

\begin{tabular}{|c|c|c|c|}
\hline Grupo(s) & Modo de propagação & Tipo de falhas associadas & Orientação dos esforços principais \\
\hline $6 a, 6 b$ & Cisalhamento & Falhas inversas & $\begin{array}{c}\sigma 1 \text { horizontal } \sim \text { NS } \\
\sigma 3 \text { vertical }\end{array}$ \\
\hline 1 & Híbrido & Falhas transcorrentes & $\begin{array}{l}\sigma 1 \text { horizontal } \sim \text { N20-50W } \\
\sigma 3 \text { horizontal } \sim \text { N40-70E }\end{array}$ \\
\hline 2d & Híbrido & - & $\begin{array}{c}\sigma 1 \text { mergulha } 50^{\circ} \text { para sul } \\
\sigma 3 \text { mergulha } 40^{\circ} \text { para Norte }\end{array}$ \\
\hline $2 a, 2 b, 2 c$ & $\begin{array}{c}2 \mathrm{2a}-\text { extensional } \\
2 \mathrm{~b}+2 \mathrm{c}-\text { híbrido a cisalhamento }\end{array}$ & Falhas normais & $\begin{array}{c}\sigma 1 \text { vertical } \\
\sigma 3 \text { horizontal } \sim \text { NS }\end{array}$ \\
\hline 4 & Cisalhamento & Falhas inversas & $\begin{array}{c}\sigma 1 \text { horizontal } \sim \text { ENE } \\
\text { б3 vertical }\end{array}$ \\
\hline 3 & $?$ & $?$ & $\sigma 1$ vertical ou $\sigma 1$ horizontal $\sim$ N30E \\
\hline $5 a, 5 \mathbf{b}$ & Cisalhamento/híbrido & $\begin{array}{l}\text { Reativação da foliação, difícil } \\
\text { determinação do regime tectônico } \\
\text { e da orientação dos esforços }\end{array}$ & \\
\hline
\end{tabular}

apresentar plumas e estrias no rumo do mergulho, ambas consistentes com o caráter híbrido.

As fraturas do grupo 2a (direção E-W e mergulho subvertical) são consideradas como contemporâneas aos grupos $2 b$ e $2 c$, pois apresentam intervalo de direções muito restrito (Figura 5), que é consistente com propagação extensional e com o campo de esforços que gerou os grupos $2 \mathrm{~b}$ e $2 \mathrm{c}$. Passagem transicional de fratura $2 \mathrm{a}$ para fratura 2c (Figura 8), reforça a contemporaneidade destes grupos. A ocorrência de fraturas extensionais (2a) e híbridas (2b e 2c) indica que houve mudança na magnitude dos esforços durante este evento tectônico, possivelmente em conjunto com atuação de pressão de fluidos. A presença de estrias de caimento baixo $\left(10^{\circ}\right.$ e $\left.35^{\circ}\right)$ no grupo 2 a é interpretada como reativação transcorrente, possivelmente pelo campo de esforços do grupo 1, pois fraturas deste grupo terminam em fraturas 2c (Figura 8).

Fratura do grupo $2 \mathrm{~d}$ termina e encurva-se ao se aproximar de fratura $2 b$, sugerindo que esta última seja mais antiga. A variação contínua dos mergulhos, entre $60^{\circ}$ e $40^{\circ}$, e a constância na direção (N75-85W, na GS3, e N60-80E, na GS4) para o grupo 2d, mais marcante na GS3, sugere que estas fraturas tenham sido geradas em um único evento, cujo regime de esforços é distinto daqueles das falhas andersonianas (Price e Cosgrove, 1990), com $\sigma 1$ de mergulho ao redor de $50^{\circ}$, para sul, posicionado na bissetriz do leque formado pelo grupo $2 \mathrm{~d}$, e $\sigma 3 \mathrm{com}$ mergulho de $40^{\circ}$ para norte. $\mathrm{O}$ ângulo $2 \theta$ de $20^{\circ}$ indica caráter híbrido. A proximidade de atitudes dos grupos $2 \mathrm{~b}$ e $2 \mathrm{~d}$, com variação apenas nos valores do mergulho, sugere que houve rotação do esforço $\sigma 1$, que era vertical, quando da geração do grupo $2 \mathrm{~b}$, e passou a mergulhar $50^{\circ}$, quando as fraturas do grupo $2 \mathrm{~d}$ foram geradas.

As fraturas do grupo 1 (N5-65W/subvertical) foram interpretadas como de cisalhamento ou híbridas, geradas em evento transcorrente, pois distribuem-se em um intervalo angular (presumivelmente $2 \theta$ ) que varia de 45 a $50^{\circ}$ (N15-65W, N10-55W e N5-50W, nas pedreiras GS1, GS3 e GS4, respectivamente). A direção do esforço máximo principal $(\sigma 1)$ situa-se no intervalo N20-50W, como indicado pelo diagrama de diedros retos (Figura 8D) e pelas direções do grupo 1 nas pedreiras GS1 e GS3, onde é mais marcante. Fraturas com plumas, de direção N35-40W (GS1) e dique, delimitado por fraturas N35W (GS3, Figura 8A, B), indicam componente extensional importante. Na GS3, a superfície de fratura N12W/79NE (78/79) apresenta alternância de faixas estriadas com faixas não estriadas, indicando movimento sinistral (Figura 8C). As faixas, no seu conjunto, desenham uma pluma com eixo horizontal, sugerindo a coexistência dos modos de propagação por cisalhamento e por extensão na geração desta fratura, típico de fraturas híbridas. Estrias com caimentos oblíquos, de $45^{\circ}$ a $70^{\circ}$, em falhas do grupo 1 (Figura 5C e 6C), sugerem reativação.

As fraturas do grupo 6 a foram interpretadas como falhas inversas, como indicado pelas estrias no rumo do mergulho (GS3 e GS4) (Figura 9D e 9E). Portanto, este evento foi do tipo compressivo, com $\sigma 1$ horizontal de direção NS e $\sigma 3$ vertical, e posterior ao grupo 1, como indicado por terminação observada na GS3. O grupo $6 \mathbf{b}$ foi interpretado como conjugado do $6 \mathrm{a}$, pois apresenta mesma direção, mas mergulho no sentido oposto. Este evento compressivo pode ter sido responsável pela reativação da foliação de gnaisse da pedreira GS1, gerando fraturas de mesma atitude que as do grupo $5 \mathrm{~b}$, que ocasionalmente podem terminar em fraturas grupo 1 .

Finalmente, é importante ressaltar que as fraturas sub-horizontais ou de baixo ângulo observadas na área de estudo poderiam ser interpretadas, segundo o senso comum, como juntas de alívio, que poderiam tratar-se de fraturas extensionais ocasionadas por remoção de carga, devido a erosão. No entanto, fraturas extensionais são perpendiculares a um esforço mínimo principal ( $\sigma 3)$ extensional, e este não pode ser originado pela simples remoção de carga (o diagrama de Mohr-Griffith ilustra este controle; ver por exemplo, Cosgrove, 1998. Martel (2011) reforça estas considerações dizendo que atribuir a formação de juntas sub-horizontais, ou paralelas à superfície do terreno (referidas, em geral, 
como sheeting joints), a alívio de carga é inconsistente com observações relevantes e, em seu artigo, conclui que tais estruturas são originadas por esforços tectônicos de regime compressivo atuando em conjunto com a curvatura da superfície do terreno.

\section{Comparação com a literatura}

A correlação dos eventos de deformação rúptil aqui descritos com aqueles dos depósitos paleogênicos e neogênicos da Bacia de Taubaté e da Bacia de São Paulo não é simples, pois as rochas aqui analisadas são muito mais antigas. No entanto, uma tentativa de correlação é feita tendo como base o fato da área de estudo estar inserida no contexto tectônico que gerou a Bacia de São Paulo, pertencente ao Rifte Continental do Sudeste do Brasil - RCSB (Riccomini, 1989). As bacias do RCSB foram geradas por evento extensional proeminente, do Paleógeno, em que estruturas antigas do embasamento, principalmente de direção ENE, foram reativadas como falhas normais. $\mathrm{Na}$ área de estudo foi identificado um evento tectônico extensional, também proeminente, que corresponde ao que gerou as fraturas EW (a ENE no GS4), verticais e extensionais (grupo 2a), bem como falhas normais de mergulhos ao redor de $60-70^{\circ}$ (grupos $2 \mathrm{~b}$ e 2c). É importante realçar que a Bacia de São Paulo é delimitada a norte por estruturas de direção EW e, portanto, paralelas a esse grupo de fraturas.

Outro evento marcante na área de estudo, com uma quantidade de fraturas ainda maior que a dos grupos $2 \mathrm{a}, 2 \mathrm{~b}$ e 2c, é o de caráter transcorrente que gerou as imponentes fraturas e zonas de fraturas do grupo 1, com $\sigma 1$ horizontal, de direção N35-50W. As relações de terminação entre os grupos de fraturas indicam que este é posterior ao evento que gerou os grupos $2 \mathrm{a}, 2 \mathrm{~b}$ e $2 \mathrm{c}$. Estruturas e regime de esforços semelhantes são descritos com frequência na literatura, não só para os depósitos do RCSB, mas também para outras partes do Estado de São Paulo. Tal evento de deformação é considerado neogênico e quaternário (Hasui et al., 1995) ou pleistocênico (Riccomini, 1989; Salvador e Riccomini, 1995; Hiruma et al., 2001). No entanto, o dique intrudido em fraturas do grupo 1, caso seja de origem alcalina e pertencente à última fase de magmatismo alcalino, de 55-40 Ma (Guedes et al., 2005), conferiria idade mínima do Paleógeno para tais fraturas. Esta hipótese, por enquanto, fica em aberto, pois a idade do dique não foi determinada, já que está muito alterado; no entanto, pode-se sugerir que o campo de esforços que gerou o grupo 1, pela sua forte expressão no Estado, tenha atuado em vários momentos da evolução da tectônica cenozóica e de forma alternada com os demais campos de esforços.

Os demais eventos identificados são subordinados e de difícil correlação com os descritos na literatura. Os grupos $4,3,5 \mathrm{a}$ e $5 \mathrm{~b}$ são mais antigos que o grupo 2 e, portanto, anteriores à geração da Bacia São Paulo. Os grupos 2d, 6a e 6b, por outro lado, são possivelmente resultantes de variação lateral de esforços e específicos da região de estudo. Tais variações são esperadas para porções mais superficiais da crosta (Talbot e Sirat, 2001; Maloney et al., 2006). Com relação ao campo de esforços atual, não é possível extrapolar os dados regionais de esforço máximo horizontal $\left(\mathrm{SH}_{\max }\right)$, apresentados em Assumpção et al. (2011), ao local da área de estudo, pois não existe detalhe de informações suficiente para isso.

\section{Modelo geométrico da rede de fraturas e caminhos preferenciais de fluxo}

O modelo geométrico (Figura 12) foi elaborado seguindo os princípios que são descritos a seguir.

$\mathrm{Na}$ área industrial do Jurubatuba e adjacências afloram mica-xistos e gnaisses. As perfilagens ópticas, realizadas nas porções mais superficiais dos poços por Fiume (2014), confirmam o amplo predomínio de gnaisses contendo bandas ora mais micáceas, ora mais quartzo-feldspáticas, cuja foliação varia muito de atitude, mostrando que está dobrada. Dentre as pedreiras visitadas, a que mais se assemelha a estas condições é a GS1 e, por este motivo, o modelo representa a atitude da foliação nele identificada. As fraturas de mergulhos elevados dos grupos 1, 2a, 2b, 2c e 3 estão bem representadas em três pedreiras, sendo, por este motivo, consideradas de ocorrência regional e, portanto, extrapoláveis para a área do Jurubatuba e representados no modelo. Os espaçamentos representados, medidos nas GS1, GS3 e GS4, oscilam, de forma aleatória, entre os valores mínimo e máximo (Figura 12). Os comprimentos são mais incertos que os espaçamentos; no entanto, espera-se que, pelo menos em parte, os grupos mais jovens terminem nos mais antigos, assim o comprimento dos primeiros é limitado pelo espaçamento dos segundos. Dos grupos de mergulho baixo, apenas o 5b, subparalelo à foliação, foi representado, pois os demais são de ocorrência mais restrita. Os grupos $7 \mathrm{a}$ e $7 \mathrm{~b}$ não são representados por serem exclusivos da GS2.

A classificação relativa dos grupos de fraturas, em termos de fluxo preferencial, foi resultado da observação de feições diagnósticas de fluxo, tais como alteração e revestimento, da superfície da fratura, por hidróxidos de ferro (Tabela 3 ). Presença de vegetação e saídas de água deve ser considerada junto com a alteração da rocha, pois tais feições sozinhas podem ser resultado de fluxo de água causado pelas perturbações originadas da exploração das pedreiras. Para esta análise, apenas as GS1 e GS3 foram consideradas, pois a GS4 é uma pedreira rasa e está mais alterada de um modo geral, e a GS2 não é representativa dos grupos mais conspícuos da região estudada. Nota-se, na Tabela 3, que as porcentagens encontradas para a presença de hidróxido de ferro para a GS1 e GS3 indicam relações opostas, sendo que a maior diferença entre as pedreiras é que na GS1 a interconexão entre as fraturas é elevada e proporcionada pelas 


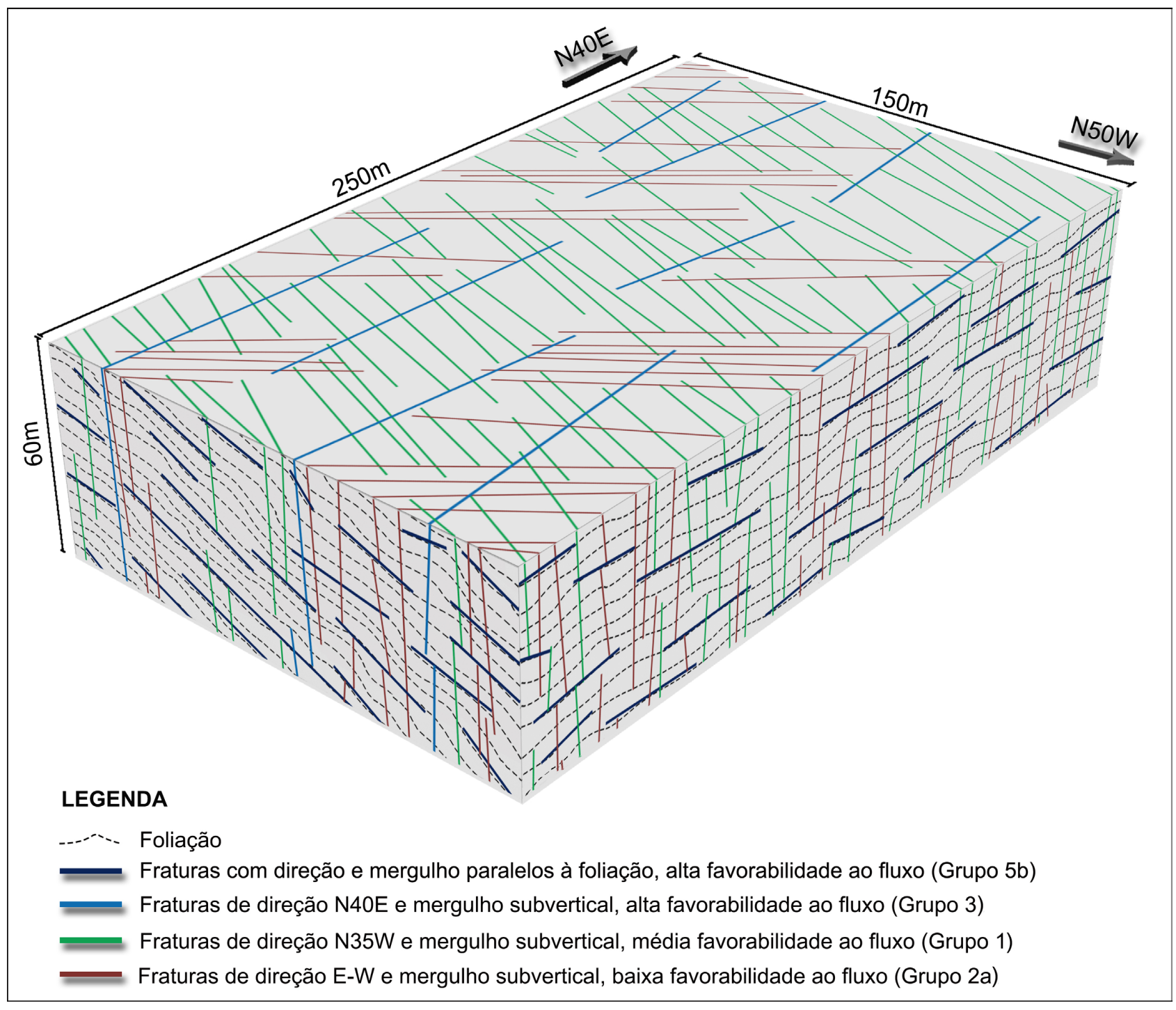

Figura 12. Modelo geométrico de fraturas representando os elementos de relevância ao fluxo de água subterrânea na área de estudo. Notar que os grupos $5 \mathrm{~b}$ e 1 tendem a dominar o fluxo e que, apesar do grupo 1 tender a terminar no 5b, as suas zonas de fraturas propagam-se de forma contínua. Com relação às fraturas de mergulho baixo, apenas o grupo $5 b$ foi representado, pois os grupos $4 a, 4 b, 5 a, 6 a, 6 b$ são de ocorrência esparsa e localizada. 0 fato das fraturas mais antigas serem mais longas e tenderem a interromper a propagação das mais novas foi determinante para o traçado e continuidade dos vários grupos.

Tabela 3. Feições diagnósticas e as porcentagens observadas para os grupos de fratura. Assim, hidróxidos de Fe, para o grupo 1, foram observados em 70\% (GS1, N=110) e 30\% (GS3, N=141) das fraturas medidas; para o grupo 2a, 40\% (GS1, $N=11)$ e $2 \%$ (GS3, $N=36)$, bem como $7 \%$ e 10\%, para 2b $(\mathrm{N}=26)$ e 2d $(\mathrm{N}=40)$, respectivamente; para o grupo 3, $40 \%$ (GS1, N=13) e $60 \%$ (GS3, N=20). N = número de fraturas medidas.

\begin{tabular}{|c|c|c|c|c|c|c|}
\hline \multirow{2}{*}{ Grupo } & \multicolumn{3}{|c|}{ GS1 } & \multicolumn{3}{|c|}{ GS3 } \\
\hline & $\mathrm{N}$ & HidroxFe & Rocha Alt/Veg/Água & $\mathrm{N}$ & HidroxFe & Rocha Alt/Veg/Água \\
\hline 1 & 110 & $70 \%$ & $0 \%$ & 141 & $30 \%$ & $10 \%$ \\
\hline $2 a$ & 11 & $40 \%$ & $20 \%$ & 36 & $16 \%$ & $2 \%$ \\
\hline $2 b$ & - & - & - & 26 & $7 \%$ & $0 \%$ \\
\hline $2 d$ & - & - & - & 40 & $10 \%$ & $10 \%$ \\
\hline 3 & 13 & $40 \%$ & $0 \%$ & 20 & $60 \%$ & $50 \%$ \\
\hline $5 b$ & 7 & & & - & - & - \\
\hline
\end{tabular}


longas fraturas sub-horizontais (5b), paralelas à foliação. A conectividade na GS3 é bem menor, sendo razoável supor que a baixa porcentagem de hidróxidos de ferro nas fraturas dos grupos $2 \mathrm{a}, 2 \mathrm{~b}$ e $2 \mathrm{c}$ é devida à menor conexão de tais fraturas. Assim, tal grupo teria menor importância para o fluxo devido a esta característica. Já o grupo 3, na GS3, apresenta grande continuidade e causou alteração terrosa intensa da rocha, sugerindo ser o de maior fluxo preferencial relativo nesta pedreira; no entanto, seu espaçamento é grande, o que reduz sua importância para o fluxo. Por fim, o grupo 1 é o grupo vertical de maior importância para o fluxo no contexto da GS1, sendo equiparável ao grupo 5b, sub-horizontal. Este último, devido ao espaçamento muito menor, ganha mais importância que o grupo 1, especialmente nas porções em que a foliação apresenta baixo ângulo ( $\sim 30^{\circ}$ ou menor). Assim, em ordem crescente de importância para o fluxo temos: grupos $2 \mathrm{a}, 2 \mathrm{~b}$ e $2 \mathrm{~d}$ (2c não é considerado individualmente pela sua menor ocorrência); grupo 3; grupo 1 e grupo $5 b$.

As relações de terminação entre as fraturas são um aspecto importante no desenho do modelo geométrico, pois é um fator que limita o comprimento das fraturas, quando elas estão suficientemente próximas entre si. Assim, em linhas gerais, o modelo indica que a componente horizontal do fluxo será dominada em conjunto pela foliação e pelo grupo $5 \mathrm{~b}$; na vertical, o fluxo mais importante também deve ocorrer ao longo do grupo 1 , onde este estiver presente, bem como ao longo do mergulho da foliação, ora para SE, ora para NW, com as linhas de charneira das dobras (de direção $\mathrm{NE}$ ) constituindo um divisor para este fluxo. A importância de fraturas paralelas à foliação para o fluxo de água é enfatizada por Manda et al. (2008), pois podem aumentar a transmissividade do meio em 20 a $30 \%$.

Com relação à evolução da deformação rúptil na região estudada e aos efeitos do campo de esforços mais recente sobre o fluxo preferencial dos grupos de fraturas, sugere-se que o evento compressivo com $\sigma_{1}$ NS, possivelmente o evento tectônico mais recente na região estudada e que gerou os grupos $6 \mathrm{a}$ e $6 \mathrm{~b}$, teria o efeito de reativar, por cisalhamento, tanto o grupo 1 como o 3 , proporcionando fluxos de água semelhantes para ambos; da mesma forma, pode ter reativado a foliação por cisalhamento. Por outro lado, teria o efeito de diminuir a abertura (e o fluxo) dos grupos 2a, $2 \mathrm{~b}$ e $2 \mathrm{c}$, o que também pode explicar o fluxo relativamente menor destes últimos na GS3; porém, não explica a indicação de fluxo (hidróxidos de Fe) nas fraturas 2a da GS1. É possível que exista, para um mesmo período de tempo, variação lateral na orientação dos esforços mais recentes dentro da região onde estão situadas as pedreiras. Brusca variação lateral de esforços, em regiões relativamente pequenas, já foi documentada na literatura (Talbot e Sirat, 2001), sendo que este comportamento é considerado comum nas porções mais superficiais da crosta, onde forças de primeira ordem podem ser sobrepujadas por fatores locais (Maloney et al., 2006).

\section{CONCLUSÕES}

O levantamento e análise estrutural realizados em quatro pedreiras próximas à área de interesse complementam, pelo menos parcialmente, os dados coletados na área industrial de Jurubatuba, pois mostram que alguns grupos de fraturas de mergulhos elevados são de ocorrência regional. A coleta de dados nas perfilagens dos poços verticais é representativa apenas para fraturas de baixo a médio ângulo de mergulho, e os dados de fraturas subverticais coletados nas pedreiras podem ser utilizados para se obter uma melhor aproximação da realidade na área do Jurubatuba. Em ordem decrescente de importância, quanto à sua frequência e continuidade, os grupos regionais são: fraturas N0-50W conjugadas ou híbridas, geradas em evento transcorrente com $\sigma 1 \mathrm{~N} 20-50 \mathrm{~W}$ (grupo 1); fraturas EW, extensionais, subverticais (grupo 2a), ou de cisalhamento a híbridas com mergulho de 60 a $70^{\circ}$ (grupos $2 \mathrm{~b}$ e $2 \mathrm{c}$ ), todas geradas durante regime tectônico de falhas normais com $\sigma 3$ de direção NS, correlacionável ao evento extensional que gerou a Bacia São Paulo, dentro do contexto do RCSB; e NE, de grande espaçamento e mergulhos variando entre 60 e $90^{\circ}$ (grupo 3). Dentre os grupos de mergulhos baixos, destacam-se as fraturas N10-40E, com mergulhos de 10 a $30^{\circ}$ predominantemente para SE e subparalelas à foliação de gnaisses, sendo de pequeno espaçamento e grande extensão lateral (grupo 5b). Os demais grupos de mergulho baixo são de ocorrência mais localizada, destacando-se o de direção EW; fraturas de cisalhamento geradas por regime tectônico de falhas reversas com $\sigma 1$ de orientação NS, e correspondente ao campo de esforços mais recente identificado na área de estudo (grupos 6a e 6b).

A GS1, por ser constituída de gnaisses, é considerada o melhor análogo da área do Jurubatuba; assim, o modelo geométrico reproduz suas principais características, que são foliação de baixo a médio mergulho, que exerce controle importante na propagação dos demais grupos de fraturas. A foliação com mergulho baixo para SE é intensamente reativada, gerando fraturas contínuas (grupo 5b), ao longo das quais indícios de fluxo são importantes, indicando ocorrência de fluxo preferencial. Zonas de fraturas NW subverticais (grupo 1), de grande continuidade, constituem caminhos de fluxo preferencial também significativo e devem controlar o fluxo vertical onde estiverem presentes. As fraturas subverticais NE (grupo 3), apesar de serem transmissivas em alguns locais, apresentam grande espaçamento, sugerindo serem de importância apenas local para o fluxo. Finalmente, as fraturas EW (subverticais ou de mergulho médio), apesar de serem frequentes, são as de menor fluxo relativo. As charneiras das dobras com eixo NE podem constituir divisores de fluxo de água subterrânea. Sugere-se que o evento mais recente, de falhas reversas com $\sigma 1$ NS (grupos 6a e 6b), pode contribuir para as maiores transmissividades, tanto da foliação como das fraturas NW e NE (grupos 1 e 3), pois propiciaria reativação destas estruturas por cisalhamento, 
ao passo que reduziria a transmissividade das fraturas EW (subverticais e de mergulhos intermediários, grupos 2a, 2b e 2c). Os resultados de análise estrutural de dados coletados em perfilagens acústicas e ópticas e de velocidade de fluxo em poços verticais, a serem publicados em breve, bem como os ensaios hidráulicos a serem realizados, também na área do projeto Jurubatuba, deverão fornecer dados relevantes para avanço do modelo geométrico aqui proposto no sentido de obtenção de um modelo conceitual de fluxo.

\section{AGRADECIMENTOS}

Agradecemos às empresas Embu SA(GS1), Grupo Votorantim (GS3) e Grupo Basalto (GS2 e GS4), que permitiram que visitássemos as pedreiras inúmeras vezes, conferindo-nos todo o apoio necessário. Sem esta colaboração, o presente trabalho não teria sido possível. Agradecemos à FINEP, que financiou os trabalhos de campo no âmbito do projeto JURUBATUBA, bem como à CAPES E FAPESP, que forneceram bolsa de Mestrado à aluna Bruna Fiume. Agradecemos aos então estudantes do curso LiGEA-IGcUSP, Elthon Nakashima, e do curso de Mestrado do IGc-USP, Marcelo A. Freimann, pelas importantes colaborações nos trabalhos de campo. Finalmente, agradecemos aos três relatores anônimos da Revista Geologia USP que contribuíram, com sugestões relevantes, para a melhoria deste texto.

\section{REFERÊNCIAS}

Almeida, F. F. M. (1976). The system of continental rifts bordering the Santos Basin, Brazil. Anais da Academia Brasileira de Ciências, 48(Supl), 15-26.

Alves, F. M. (2008). Tectônica rúptil aplicada ao estudo de aquifero em rochas cristalinas fraturadas na região de Cotia, SP. Tese (Mestrado). São Paulo: Instituto de Geociências, Universidade de São Paulo - USP.

Angelier, J., Mechler, P. (1977). Sur une methode grafique de recherche des constraintes principales également utilisable en tectonique et en seismologie: la methode des diedres droits. Bulletin de la Société Géologique de France, 7, 1309-1318.

Assumpção, M., Loper, A. E. V., Zevallos, I., Ferreira, J. M., Nascimento, A. (2011). Intraplate stress field in Brazil from earthquake focal mechanisms. Conferencia Internacional en Homenaje a Alberto Giesecke. Lima: CERESIS.

Barton, C. A., Zoback, M. D., Moos, D. (1995). Fluid flow along potentially active faults in crystalline rock. Geology, 23(8), 683-686.
Cosgrove, J. W. (1998). The role of structural geology in reservoir characterization. Geological Society of London, Special Publications, 127(1), 1-13.

Fernandes, A. J., Maldaner, C. H., Rouleau, A. (2011). Análise das fraturas nos basaltos de Ribeirão Preto, SP: aplicação à elaboração de modelo hidrogeológico conceitual. Geologia USP: Série Cientifica, 11(3), 43-64.

Fernandes, A., Rudolph, D. L. (2001). The influence of Cenozoic tectonics on the groundwater-production capacity of fractured zones: a case study in Sao Paulo, Brazil. Hydrogeology Journal, 9(2), 151-167.

Ferrill, D. A., Winterle, J., Wittmeyer, G., Sims, D., Colton, S., Armstrong, A., Morris, A. P. (1999). Stressed rock strains groundwater at Yucca Mountain, Nevada. GSA Today, 9(5), 1-8.

Fiume, B. (2014). Geologia estrutural de detalhe para elaboração de modelo conceitual de circulação de água subterrânea: estudo de caso em Jurubatuba, SP. Tese (Mestrado). São Paulo: Instituto de Geociências, Universidade de São Paulo - USP.

Guedes, E., Heilbron, M., Vasconcelos, P. M., Morisson Valeriano, C., Almeida, J. C. H., Teixeira, W., Thomaz Filho, A. (2005). K-Ar and $40 \mathrm{Ar} / 39 \mathrm{Ar}$ ages of dikes emplaced in the onshore basement of the Santos Basin, Resende area, SE Brazil: implications for the south Atlantic opening and Tertiary reactivation. Journal of South American Earth Sciences, 18(3), 371-382.

Hasui, Y., Facincani, E. M., Santos, M., Jimenez-Rueda, J. R. (1995). Aspectos estruturais e neotectônicos na formação de boçorocas na região de São Pedro, SP. Geociências, 14(2), 59-76.

Heilbron, M., Pedrosa-Soares, A. C., Campos Neto, M. D. C., Silva, L. D., Trouw, R. A. J., Janasi, V. A. (2004). Província Mantiqueira. In:, V. Mantesso-Neto, A. Bartorelli, C. D. R. Carneiro, B. B. Brito-Neves (Eds.), Geologia do continente Sul-Americano: evolução da obra de Fernando Flávio Marques de Almeida, 203-234. São Paulo: Beca.

Hiruma, S. T., Riccomini, C., Modenesi-Gauttieri, M. C. (2001). Neotectônica no planalto de Campos do Jordão, SP. Revista Brasileira de Geociências, 31(3), 375-384.

Maloney, S., Kaiser, P., Vorauer, A. (2006). A reassessment of in situ stresses in the Canadian Shield. Golden Rocks 2006, The 41st US Symposium on Rock Mechanics (USRMS). American Rock Mechanics Association.

Manda, A. K., Mabee, S. B., Wise, D. U. (2008). Influence of rock fabric on fracture attribute distribution and implications for groundwater flow in the Nashoba Terrane, eastern Massachusetts. Journal of Structural Geology, 30(4), 464-477. 
Martel, S. J. (2011). Mechanics of curved surfaces, with application to surface-parallel cracks. Geophysical Research Letters, 38(20)

Morin, R. H., Savage, W. Z. (2003). Effects of crustal stresses on fluid transport in fractured rock: case studies from northeastern and southwestern USA. Hydrogeology Journal, 11(1), 100-112.

Pino, D. S. (2012). Structural hydrogeology in the Kenogamy Uplands, Quebec, Canada. Tese (Doutorado). Chicoutimi: L'Université du Québec à Chicoutimi.

Price, N. J., Cosgrove, J. W. (1990). Analysis of geological structures. Cambridge: Cambridge University Press.

Priest, S. D. (1993). Discontinuity analysis for rock engineering. London: Chapman \& Hall.

Riccomini, C.(1989). O Rift Continental do Sudeste do Brasil. Tese (Doutorado). São Paulo: Instituto de Geociências, Universidade de São Paulo - USP.

Riccomini, C., Coimbra, A. M. (1992). Geologia da Bacia Sedimentar. In: A. Negro Junior, A. A. Ferreira, U. R. Aonso, P. A. Luz (Ed.), Solos da cidade de São Paulo, 37-94. São Paulo: ABMS/ABEF.

Riccomini, C., Sant'Anna, L. G., Ferrari, A. L.(2004). Evolução geológica do rift continental do Sudeste do Brasil.
In: V. Mantesso-Neto, A. Bartorelli, C. D. R. Carneiro, B. B. Brito-Neves (Eds.), Geologia do continente Sul-Americano: evolução da obra de Fernando Flávio Marques de Almeida, 383-405. São Paulo: Beca.

Rouleau, A., Gale, J. E. (1985). Statistical characterization of the fracture system in the Stripa granite, Sweden. International Journal of Rock Mechanics and Mining Sciences, 22(6), 353-367.

SABESP/CEPAS-IGc-USP. (1994). Diagnóstico hidrogeológico da Região Metropolitana de São Paulo: diagnóstico final. São Paulo: SABESP, Centro de Pesquisas de Águas Subterrâneas do IGc-USP.

Salvador, E. D., Riccomini, C. (1995). Neotectônica do alto estrutural de Queluz (SP-RJ, Brasil). Brazilian Journal of Geology, 25(3), 151-164.

Talbot, C. J., Sirat, M. (2001). Stress control of hydraulic conductivity in fracture-saturated Swedish bedrock. Engineering Geology, 61(2), 145-153.

Terzaghi, R. D. (1965). Sources of error in joint surveys. Geotechnique, 15(3), 287-304.

Wahnfried, I. (2010). Modelo conceitual de fluxo do Aquitarde Serra Geral e do Sistema Aquifero Guarani na região de Ribeirão Preto, SP. Tese (Doutorado). São Paulo: Instituto de Geociências - USP. 


\title{
Application of Geophysical Logging and Straddle Packers for the Investigation of a Fractured Aquifer in a Contaminated Area by Chlorinated Solvents in Sao Paulo State, Brazil
}

\author{
Aline Fanti', Reginaldo Bertolo²*, Fabiana Vogado1, Fabiana Cagnon1, Ana Paula Queiroz ${ }^{1}$ \\ ${ }^{1}$ Waterloo Brasil Consulting Ltda, Sao Paulo, Brazil \\ ${ }^{2}$ CEPAS Groundwater Research Center, University of Sao Paulo, Sao Paulo, Brazil \\ Email: *bertolo@usp.br
}

\begin{abstract}
How to cite this paper: Fanti, A., Bertolo, R. Vogado, F., Cagnon, F. and Queiroz, A.P. (2017) Application of Geophysical Logging and Straddle Packers for the Investigation of a Fractured Aquifer in a Contaminated Area by Chlorinated Solvents in Sao Paulo State, Brazil. Journal of Water Resource and Protection, 9, 1145-1168.
\end{abstract} https://doi.org/10.4236/jwarp.2017.910075

Received: July 23, 2017

Accepted: September 17, 2017

Published: September 20, 2017

Copyright ( 92017 by authors and Scientific Research Publishing Inc. This work is licensed under the Creative Commons Attribution International License (CC BY 4.0).

http://creativecommons.org/licenses/by/4.0/ (c) (i) Open Access

\begin{abstract}
The investigation of contaminated areas in fractured aquifers represents a great technical challenge, due to the frequent conditions of heterogeneity and anisotropy of these environments, which often make it difficult to identify and predict pathways of subsurface contamination. This work aims to contribute to the development of this subject, through the presentation of the results of an investigation in which geophysical logging tools and straddle packers were used, which allowed the development of a more suitable hydrogeological conceptual model of the study area. Two boreholes were drilled and geophysical logging (gamma, caliper and high resolution acoustic televiewer) were used for the geological-structural characterization of the aquifer. Heatpulse flowmeter and straddle packers were then used to obtain data on hydraulic potentials and flows and for the collection of discrete water samples for chemical analysis. Two types of gneiss rocks were identified below the weathering zone (thickness $>30 \mathrm{~m}$ ), one with predominance of mafic bands, more weathered and with a higher fracture density, up to $65 \mathrm{~m}$, and another deeper one, with the predominance of felsic bands. Seven groups of fractures were defined, being those of Group 1, with low dip angles, the most frequent and important for flow until $65 \mathrm{~m}$, and Group 2 ( $\mathrm{N}$ to NE-SW with high dips to $\mathrm{W}$ and NW) more frequent in deeper felsic gneisses. Downward hydraulic potentials were identified down to $65 \mathrm{~m}$ and upward potentials from the bottom up to $65 \mathrm{~m}$. A hydraulic test allowed identifying the occurrence of hydraulic connection between the shallow weathering zone and the underlying fractured aquifer.
\end{abstract}




\section{Keywords}

Fractured Aquifer, Contaminated Areas, Conceptual Model

\section{Introduction}

In situations of aquifer contamination, some fundamental questions that need to be addressed for the proper management of the environmental problem are: where is groundwater moving to? what are their velocities and flow rates? how are the contaminants being transported? The answers to these questions are usually obtained through the consolidation of geology, hydrogeology and contamination information and represented in a conceptual model of the contamination of the area of environmental interest.

Although all terrains exhibit particular geological complexities, cases of contamination of fractured aquifers, especially when contaminants are chlorinated organic compounds, represent even greater challenges for the definition of the conceptual model, given its generally high heterogeneity and anisotropy, which provide high complexity and many uncertainties in defining the paths and rates of the groundwater flow.

In general, the techniques and approaches used for investigation in fractured aquifers are more complex than those conventionally used for aquifers of primary porosity. Borehole drilling with the recovery of coreholes, associated with the use of different geophysical logging techniques, discrete hydraulic tests with straddle packers and the installation of multi-level monitoring wells of different designs are techniques frequently used in such investigations. The combined use of all these techniques is being developed in recent years through a methodology called Discrete Fracture Network (DFN) [1] [2]. In general, the costs associated with drilling and in-depth investigations, in addition to the complexity, heterogeneity and variability of fracture networks, are some of the factors that make it difficult to thoroughly characterize contamination in fractured aquifers.

This work aims to contribute to the development of the subject through the presentation of the results of an investigation of a contaminated area in a fractured aquifer located in a context of a tropical humid climate, where geophysical logging tools (caliper, natural gamma, high resolution acoustic televiewer and heatpulse flowmeter) and straddle packers have been used in two boreholes to develop a more suitable hydrogeological conceptual model of the site.

The combined analysis of the geophysical logging methods assists in the interpretation of the constructive conditions of the borehole or well, the identification of the types of rocks, stratigraphy and lithological contacts, the characterization of the main groups of fractures, their geometrical properties (position in space, frequency, interconnectivity) and the evaluation of the preferential paths of groundwater and pollutants [3] [4]. The use of these methods began more than 30 years ago [5] [6] and recent studies indicate that they are quite efficient 
in the study of fractured aquifers [7] [8] [9]. The use of the heatpulse flowmeter helps to define the direction and velocity of vertical component of the water flow in the borehole, which can be used to obtain hydraulic parameters of transmissivity of fractured aquifers [10] [11] [12]. The definition of the hydraulically active zones with the heatpulse flowmeter is of great interest because they determine the discrete depths in which hydraulic tests and the collection of water samples with straddle packers may be performed. The use of straddle packers in fractured aquifer investigations is presented by a series of authors [13]-[18]. The combination of some of the geophysical logging techniques and straddle packers were employed in this work and the results are presented below.

\section{Study Area}

\subsection{Geology and Hydrogeology}

The industrial area is located $90 \mathrm{~km}$ northwest of the city of São Paulo, southeast Brazil. Geologically, it is located east of the Paraná Basin, between the Valinhos (ZCV) and Campinas (ZCC) shear zones, in the Itapira Complex [19], which belongs to the Tocantins Province [20]. The main outcropping rocks in the area are gneisses.

Based on field observations and considering the classification of soils proposed by Vaz [21], three geological units were locally defined: the first corresponds to a relatively homogeneous and isotropic eluvial soil, composed of a clay-silty material of reddish brown color. Locally, a layer of landfill with sandy portions was also verified on the first horizon. The other two underlying units were classified as weathered bedrock soil and slightly weathered bedrock (gneiss) (Figure 1).

The weathered bedrock soil is a soft material resulted from the weathering of the gneiss rocks, being composed of a silt-clayey to a silt-sandy material, with a marked presence of micaceous minerals and quartz crystals. In general, this medium exhibits behavior similar to that of a primary porosity aquifer, but with zones of greater or lesser resistance associated with structures of the parental gneiss rock, which may create preferential flow paths in the water table aquifer.

The water table aquifer is represented by this weathered bedrock soil, where the hydraulic conductivities vary from $1.29 \mathrm{E}-7$ to $4.28 \mathrm{E}-7 \mathrm{~m} \cdot \mathrm{s}^{-1}$ [22]. In this aquifer, no significant differences in hydraulic heads were observed in the vertical direction, especially among the multilevel monitoring wells installed between the depths of 3.8 and 36.9 meters.

The flow direction of the groundwater in the water table aquifer presents a predominant horizontal component to the northeast, towards the stream located at the northern boundary of the industrial unit (Figure 2). In the central portion of the area, the flow presents radial characteristics associated with the topography of the region.

The slightly weathered gneiss rock has a grayish color and a medium to fine grain size. The logs of the boreholes performed in the area and surface geophysical 


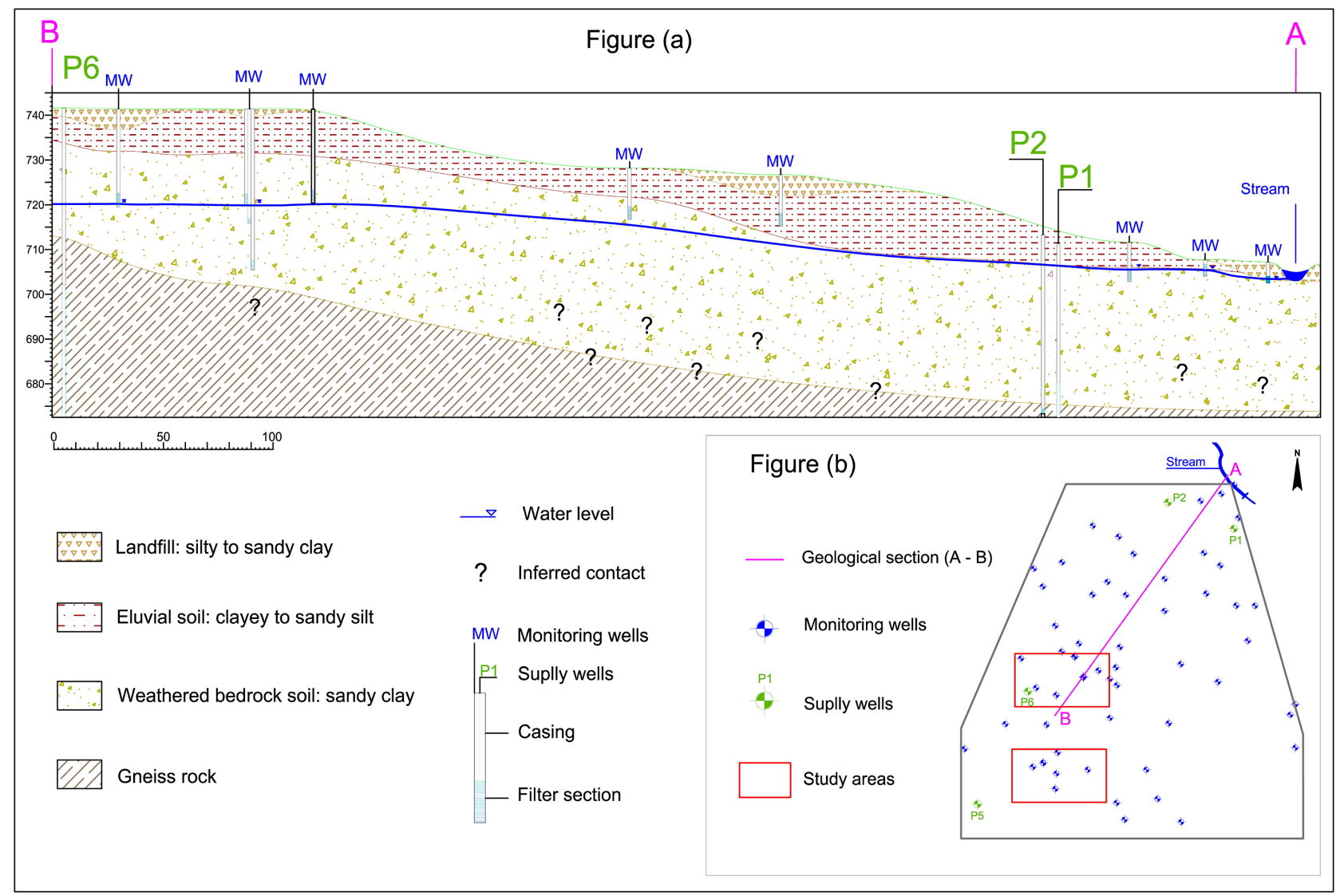

Figure 1. Geological and hydrogeological cross-section of the study area.

survey data indicate that the top of the hard rock is present at shallower depths in the west portion of the area (between 16 and $34 \mathrm{~m}$ ) and deeper in the eastern portion. The fractured structures that are favorable for the water flow are those of NNE and those of NE to ENE directions, which are present in the rocks located west of the Campinas Shear Zone (ZCC) and between the Valinhos (ZCV) and Campinas shear zones [23]. In the gneisses and granites east of the ZCV, the most favorable structures exhibit the opposite direction: NW, WNW and NNW.

\subsection{Environmental Problem}

The improper use of chlorinated solvents in the past has led to contamination of the shallow aquifer within the plant. Trace concentrations of chlorinated hydrocarbon compounds were detected in the supply well P6, located about $100 \mathrm{~m}$ from the defined source of contamination zones (Figure 2). The site neighborhood had no public water supply system at that time and water supply was exclusively performed by pumping private wells that extracted water from the fractured bedrock aquifer.

Chlorinated organic compounds are often used in a variety of industrial processes. Many of these compounds are highly toxic and, even at low concentrations in the soil, water or atmosphere, can contaminate large areas, posing risks to human health and the environment [24] [25]. In the study area, chlorinate 


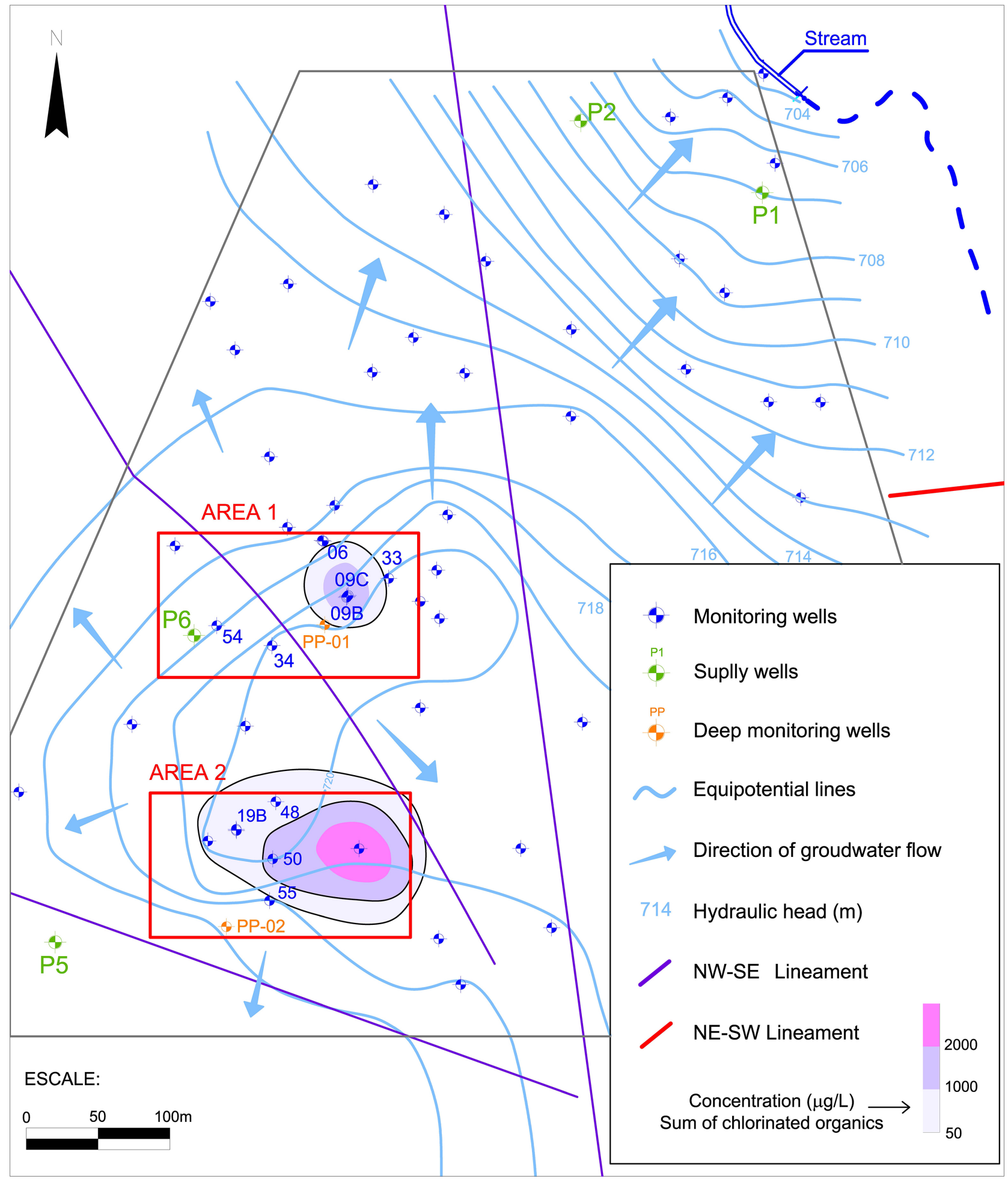

Figure 2. Potentiometric map of the water table aquifer and contour lines of the sum of the chlorinated compounds. Data gathered in April 2014. Area 1 (a), Area 2 (b).

solvents were used as degreasers in the cleaning of parts and equipment, and a single source area of contamination was not possible to be identified, since these activities happened in different places in the industrial unit. 
Environmental investigations began in 2006 and resulted in the installation of 59 monitoring wells at three depths in the water table aquifer, for horizontal and vertical delimitation of the contamination. Two sources of contamination were identified in the shallow aquifer, named in this study as Area 1 and Area 2 (Figure 2), where the compounds tetrachloroethene (PCE), trichloroethene (TCE), cis-1,2-dichloroethene (cis1,2DCE), trans-1,2-dichloroethene (trans1,2DCE), 1,1-dichloroethene (1,1DCE), 1,1-dichloroethane (1,1DCA) and vinyl chloride (VC) were detected in groundwater.

In Area 1, concentrations of more degraded compounds predominate as cis1,2DCE and vinyl chloride. Concentrations of TCE are small and observed at the deepest level of the aquifer. In Area 2, the TCE shows the highest concentration and distribution in the area. Concentrations of degraded compounds, such as cis1,2DCE and vinyl chloride, are not significant in Area 2. Local concentrations of PCE, 1,1DCE and 1,2DCA are also observed.

Taking into account the contamination scenario presented and the detection of chlorinated compounds in the deep supply well P6, installed in the fractured aquifer, it was necessary to adopt different investigation techniques to characterize the fractures and to build an initial conceptual model of flow and transport of contaminants in the aquifer, which would be the basis for the subsequent stages of environmental management and remediation.

\section{Method}

\subsection{Drilling Boreholes and Logging Data}

An organization of information from previous works was carried out initially, such as aerial image interpretations, surface geophysical surveys and local field geological mapping. This stage was important for the identification and characterization of the main rocks and structures that occur in the region, assisting in the planning of the field stages and in the choice of the investigation methods used.

For the investigation of the fractured aquifer, two boreholes were drilled in locations close to the plumes of contamination of the shallow aquifer (Figure 2), followed by the installation of two deep monitoring wells (PP-01 and PP-02). Two drilling methods were used in each borehole: the hydraulic-rotary method to drill the soft weathered bedrock until the top of the hard rock; and the rotary air percussion drilling method, to drill the hard gneiss rock. The borehole walls were cemented and cased with a 6 " carbon steel casing along the soft weathered bedrock to prevent crumbling and infiltration of the contaminated water from the shallow portions of the aquifer. As a result, well PP-01 had a total depth of $78.0 \mathrm{~m}$, being the first $39.5 \mathrm{~m}$ corresponding to the cased soft weathered bedrock. Well PP-02 had a depth of $92.0 \mathrm{~m}$, with a cased portion of $30.0 \mathrm{~m}$.

After the end of the drilling activities, the boreholes were filmed aiming to identify faciological variations of the local gneiss, zones of fractures and more 
weathered intervals. The shooting tool used is composed of two independent front and side view cameras that can be operated in stationary or rotating mode. Additionally, a caliper coupled to a probe and constituted by three articulated rods was used to record the diameter of the boreholes. Wall diameter variations provided information on possible fractures or zones of rock weakness.

Acoustic imaging and natural gamma logging techniques were used in both boreholes through a Robertson Geologging probe with vertical resolution up to 1 $\mathrm{mm}$. The High Resolution Acoustic Televiewer (HRAT) logging was performed in the boreholes in order to determine the precise oriented-location of the main fracture zones and identify the different families of fractures intercepted by the boreholes, their directions and dips. Subsequently, it was sought to correlate the fractures observed in the boreholes with surface-discontinuities mapped in previous studies.

The loggings of the natural groundwater flow inside the boreholes were performed with the use of a flowmeter, aiming to determine the flow velocity and the main inputs and outputs of groundwater in the boreholes through the identified fractures. The flowmeter model used was a Robertson Geologging one, which allowed readings with a resolution of $0.001 \mathrm{~m} \cdot \mathrm{min}^{-1}$ in up to 30 seconds after the emission of the heat pulse. At least three measurements at each point were performed, located before and after zones of fractures selected. The fractures of interest are those that presented evidence of openness, having a greater probability of flow.

\subsection{Interpretation of the Structural Data}

All the data obtained with the logging activities were inserted and interpreted in WellCad v. 5 software. The features identified with HRAT were traced and classified according to their degree of uncertainty in Fractures (traced in blue) and Possible Fractures (traced in pink). Some foliation measurements were also taken (traced in green) at each of the analyzed points. The structural data obtained (fracture attitude) are presented in the Clar compass notation (strike and dip angle) and were first compiled in spreadsheets and later imported by DIPS software v.5, analyzed in stereograms, density diagrams and histograms, to define the different groups of fractures present.

For the analysis of the fractures density and spacing, the method developed by Terzaghi [26] and adapted by Pino [27] was used to adjust the density of fractures intercepted by the borehole. This correction is necessary since the fracture data are affected by the bias of the drilling orientation and the apparent spacing of the fractures, related to the angle $(\alpha)$ that the fracture makes with the borehole axis. In this analysis, the values corrected for fractures with $\alpha$ angle greater than $20^{\circ}$ and absolute values for the other fractures were corrected, thus ensuring that all observed features are considered. The main groups or fracture families of the rock were characterized to help defining the main zones of water flow and contaminants. 


\subsection{Straddle Packers}

After the interpretation of the data obtained with the borehole logging activities, water samples were collected from fractures of the crystalline aquifer with the use of straddle packers. This equipment isolates sections of the borehole, allowing the obtainment of water samples at discrete intervals. The packers used consist of two inflatable cylindrical rubbers, coupled to a steel main support rod (Figure 3). The rubbers work as bladders and are inflated to the desired depth with the use of air compressors or gas cylinders, isolating the desired interval.

A low-flow bladder pump was used to conduct the sampling activities, being inserted inside the main support rod, which is hollow and has opening only in the filtering portion between the packers, allowing the water to enter the sealed portion into the pump. In this way, it was possible to carry out the cleaning activities of the pump and exchange hoses between the sampling events, avoiding cross contamination by the sampling equipment. Three sampling points were selected in each borehole.

Sampling activities comprised the following steps: (1) water level measurement; (2) positioning the pump and packers at the desired depth, starting from the bottom of the borehole; (3) filling the straddle packers and waiting for

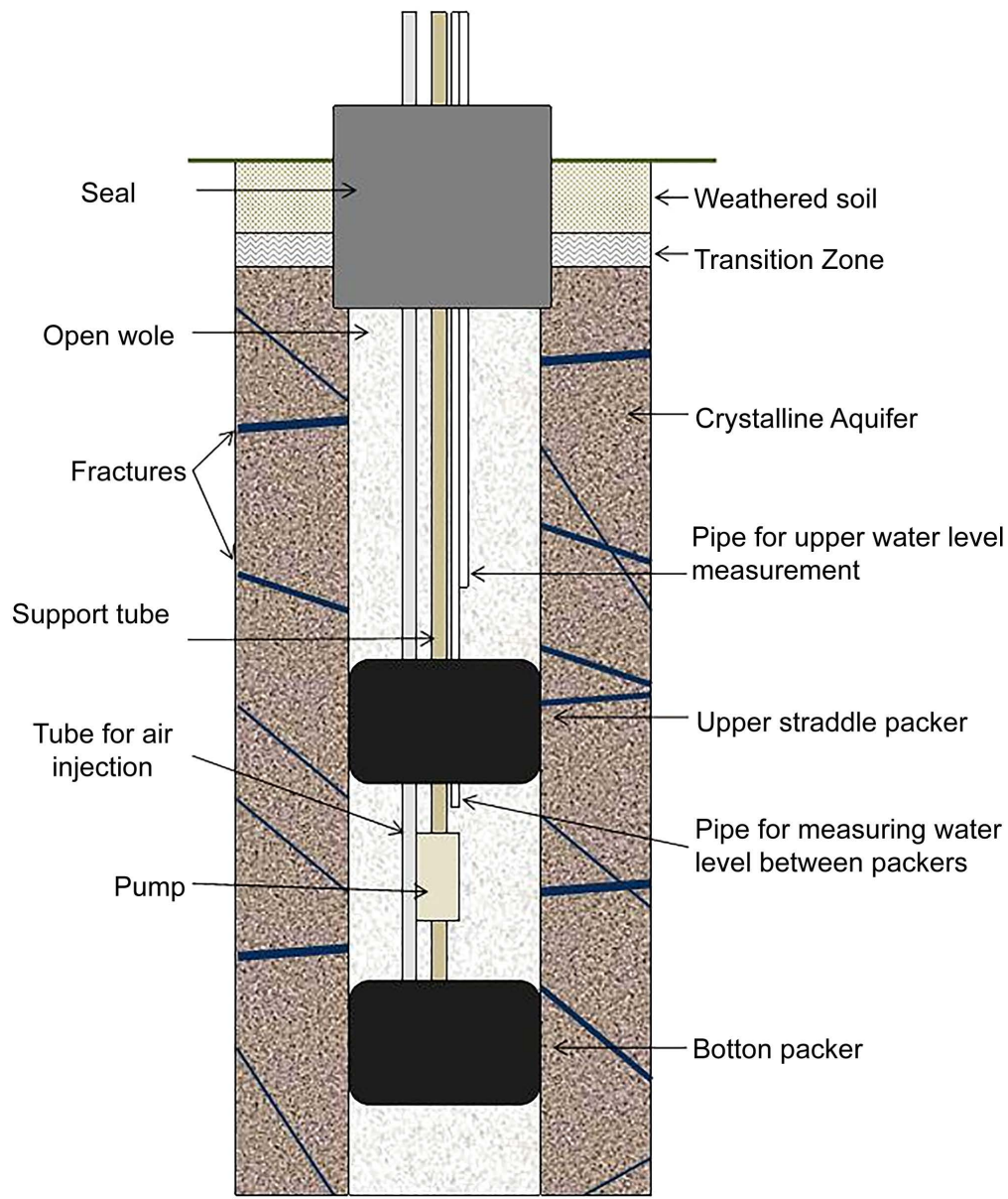

Figure 3. Sampling scheme with the straddle packers. 
approximately $30 \mathrm{~min}$ for hydraulic head stabilization, prior starting the pumping; (4) purging the water within the insulated range for approximately $30 \mathrm{~min}$; (5) measurement of hydraulic heads and physical-chemical parameters for every 5 min until stabilization; and (6) collection of groundwater samples for the analysis of volatile organic compounds (VOC) by GC/MS (USEPA method 8260B). During the sampling activities, the hydraulic heads in the isolated interval by and above the packers were monitored, in order to evaluate the efficiency of the insulation.

After the evaluation of the results of the chemical analysis, the work continued with the installation of a conventional monitoring well at each borehole, in order to allow the continuity of the monitoring in the fractured aquifer. The filters were positioned where the highest concentrations of organic compounds were detected (Figure 4). A pumping test was then conducted in the deep supply well P6, in order to evaluate the hydraulic connectivity of the deep fractured aquifer and the water table aquifer. Hydraulic heads of three monitoring wells installed in the water table aquifer were monitored during the pumping test.

\section{Results and Discussion}

\subsection{Borehole Geological Description}

The geological logs of the boreholes and the design of the monitoring wells

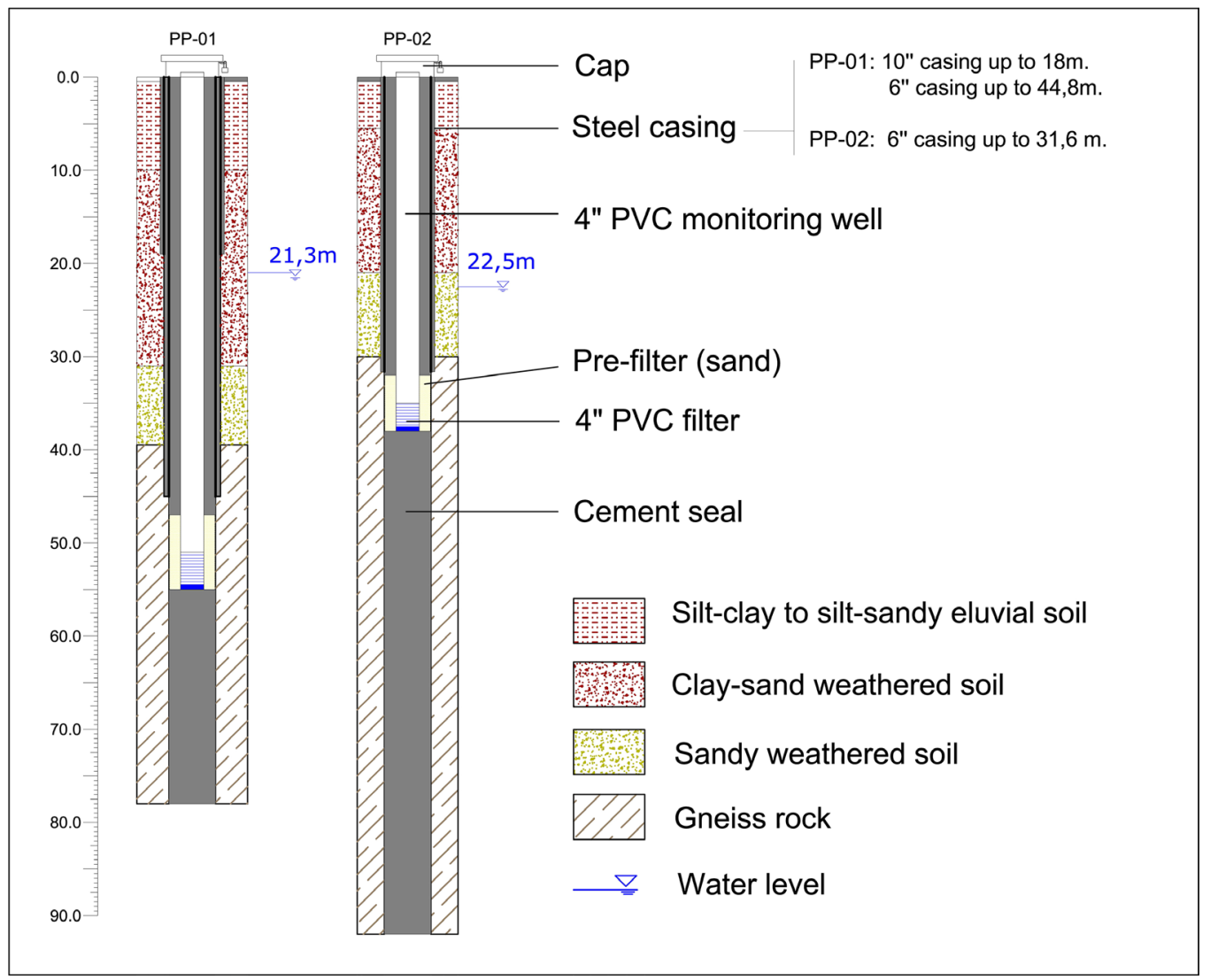

Figure 4. Geological logs and the design of the monitoring wells PP-01 and PP-02. 
PP-01 and PP-02 are presented in Figure 4. The data obtained by the caliper, gamma and HRAT logging were imported by WellCAD v.5 software, handled and analyzed together with the filming and other data collected in the field stage. These are presented in Attachment 1.

The results indicated the occurrence of two faciological zones in the gneiss rock. From the top of the rock (base of the weathered bedrock soil) to the average depth of $65.0 \mathrm{~m}$, in both boreholes, a dark gray gneiss predominates, where minerals such as biotite, hornblende, amphibole and alkali feldspar are present. After the depth of $64 \mathrm{~m}$ in the PP-01 and $65 \mathrm{~m}$ in the PP-02, the gneiss is light, of whitish color, formed essentially by quartz, alkali feldspar and plagioclase.

At both boreholes, the gneiss rock is intensely fractured, especially in the uppermost dark gneiss portion, near the contact of the weathered rock soil with the top of the fresh rock. In this portion, the gamma ray logs presented higher values, related to the greater presence of clay minerals in the rock. In depth, the rock presents a smaller number of fractures and the presence of quartz and plagioclase can also contribute to the reduction of gamma rays values (Attachment 1).

In PP-01, variations associated with the occurrence of large fractures were recorded by caliper logging between 45.0 and $61.0 \mathrm{~m}$ (Attachment 1 ). The natural gamma logging in PP-01 showed average values between 120 and $140 \mathrm{cps}$ to the approximate depth of $64.0 \mathrm{~m}$, and smaller values, in the order of $80 \mathrm{cps}$, after this depth. In PP-02 (Attachment 1), fractures with larger apparent openings are spaced and present throughout the profile, with more weathered zones located closer to the ground surface. The values of the gamma radiation range from 120 to $180 \mathrm{cps}$ to the depth of approximately $65.0 \mathrm{~m}$, when there is a reduction to values between 40 and $100 \mathrm{cps}$.

\subsection{Structural Analysis}

Based on the HRAT data, the fracture and foliations features were defined and the depth and attitude data (strike and dip) were treated in rose diagrams, histograms and stereograms, helping to define the different groups. In the stereograms, the dubious features were characterized as "Possible Fractures" and represented in blue dots, in order to facilitate the evaluation of their importance and coherence with respect to "Fractures", represented in red and used primarily for the separation of the main groups. Foliation measurements are shown in black. Figure 5 and Figure 6 present the data obtained for PP-01.

More than $30 \%$ of the features observed in PP-01, including foliation measurements, present N-S main direction, ranging from N0-25E. The section between 52 and $64 \mathrm{~m}$ presents the largest number of fractures. It is recalled that the boreholes are vertical, which makes it difficult to visualize possible existing high angle fractures, whose quantification may be underestimated. Nevertheless, the number of fractures identified parallel to the foliations, with subvertical dips, is significant. It is possible to identify at least five groups of major fractures in PP-01, described below. 
(a) Without correction

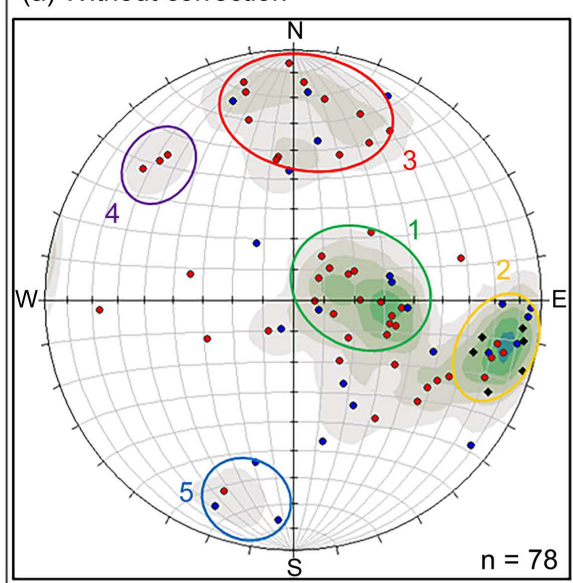

$0.00 \sim 2.00 \%$

$2.00 \sim 4.00 \%$

$4.00 \sim 6.00 \%$

$6.00 \sim 8.00 \%$

$8.00 \sim 10.00 \%$

$10.00 \sim 12.00 \%$

$12.00 \sim 14.00 \%$

$\%$ of total per $2.0 \%$ area Max. Conc. $=12.8140 \%$ (b) With correction

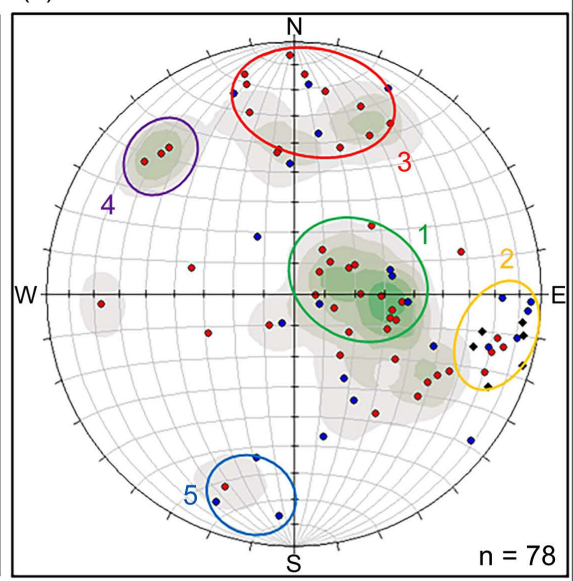

$0.00 \sim 2.50 \%$

$2.50 \sim 5.00 \%$

$5.00 \sim 7.50 \%$

- Foliation

Fracture

O Possible fracture

$7.50 \sim 10.00 \%$

$10.00 \sim 12.50 \%$

$12.50 \sim 15.00 \%$

$15.00 \sim 14.50 \%$

$\%$ of total per $2.0 \%$ area Max. Conc. $=14.8082 \%$

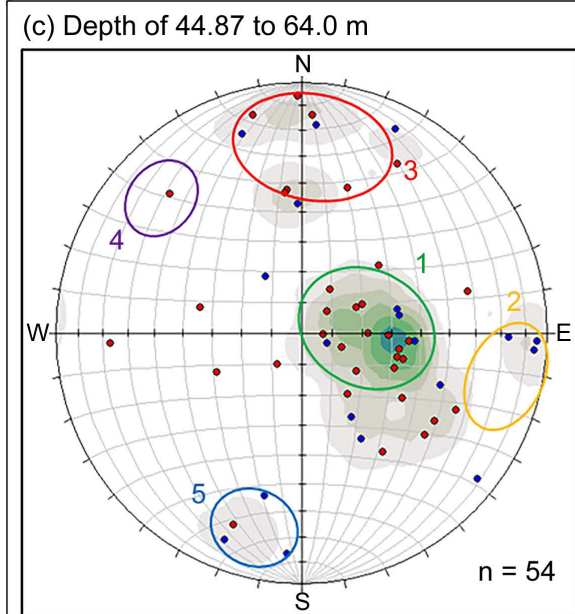

(d) Depth of 64.0 to $77.3 \mathrm{~m}$

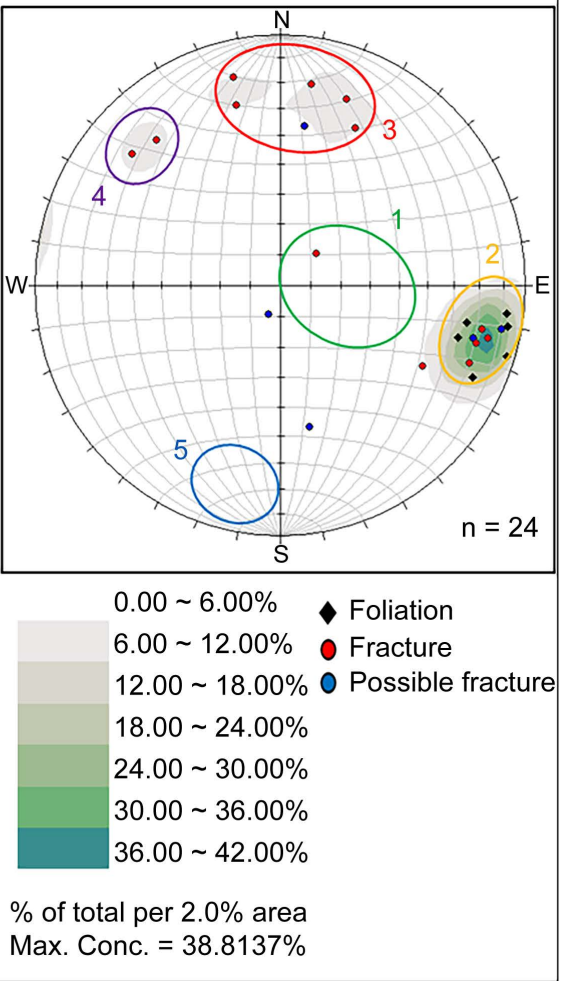

$\%$ of total per $2.0 \%$ area Max. Conc. $=16.4523 \%$
Max. Conc. $=38.8137 \%$

Figure 5. Polar projections of fracture planes present at borehole PP-01 and groups of fractures identified: (a) without Terzaghi correction; (b) with Terzaghi correction; (c) and (d) at different depths. 


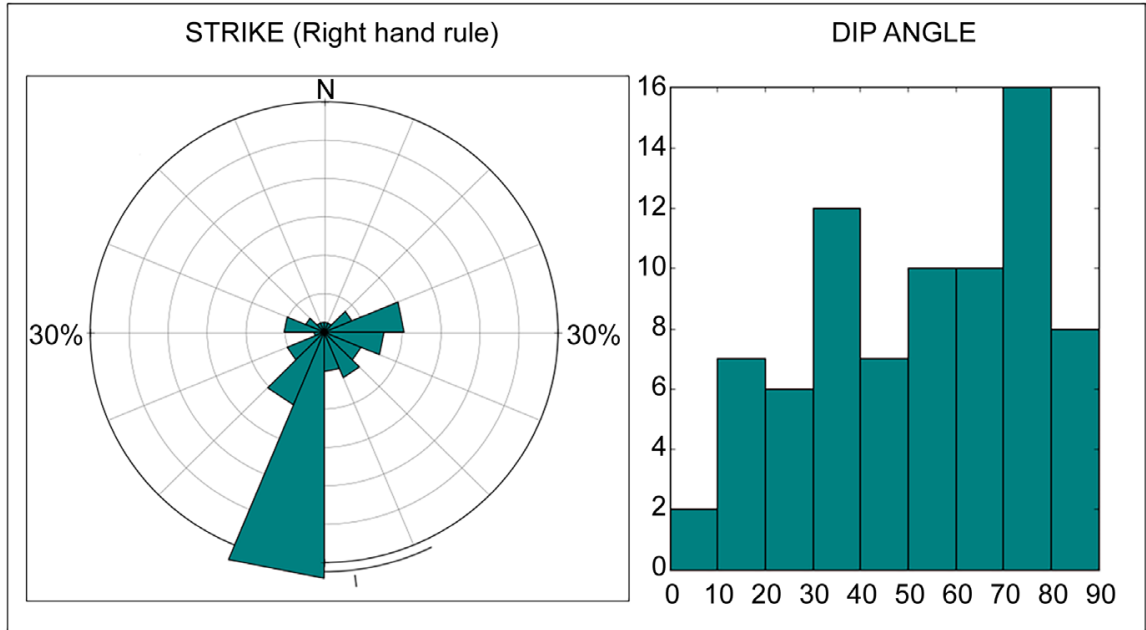

Figure 6. Statistics of strike and dip of fracture planes present at borehole PP-01.

Group 1: Sub-horizontal fractures, striking predominantly N45W to N30E and dipping less than $40^{\circ}$, preferably to $\mathrm{W}$ and with small variations to SW or NW. The fractures present a random distribution, they are apparently open and occur mainly in the most weathered dark portion of the gneiss. It is the group of greater density, smaller average spacing and with preferential occurrence in the upper portion of the rock massif.

Group 2: Structures parallel to the foliation, striking N0-22E (vertical) with high dip $\left(>60^{\circ}\right)$ to $\mathrm{W}$. This is the second group of major importance. The fractures are observed from $58 \mathrm{~m}$ depth and are more expressive in the light gneiss portion, below $64 \mathrm{~m}$. Due to high dip, group 2 fractures were not considered in the Terzaghi correction, which indicates that the number of features observed may be underestimated.

Group 3: E-W fractures predominate, dipping $>45^{\circ}$ preferably to S. Fractures of this group are more spaced throughout PP-01. Only the features observed dipping $45^{\circ}$ to $70^{\circ}$ are corrected by the Terzaghi method, according to Figure 5 .

Group 4: NE-SW fractures, dipping $60^{\circ}-70^{\circ}$ to SE. Only three representative features of this group were registered at depths of 54, 72 and $73 \mathrm{~m}$, but the group becomes more expressive after the application of the Terzaghi correction.

Group 5: E-W to WNW fractures, dipping $>55^{\circ}$ to $\mathrm{N}$. These features are observed only in the upper portion of the rock, up to $55 \mathrm{~m}$ depth and only fractures dipping $55^{\circ}$ to $70^{\circ}$ are influenced by the Terzaghi correction.

Structural data obtained for PP-02 are presented in Figure 7 and Figure 8. $40 \%$ of the observed features are NE-SW, represented mainly by fractures of Groups 1, 2 and 4. The foliation measurements also show this strike. The intervals of 35 to $43 \mathrm{~m}$ and 62 to $73 \mathrm{~m}$ represent zones intensely fractured, favorable to the groundwater flow. The fractures with the largest openings show dips of $<40^{\circ}$ and the deepest portion of the borehole presents the largest number of fractures, apparently with no openings.

In PP-02, fractures of Group 1 are characterized by a dispersed strike and low 

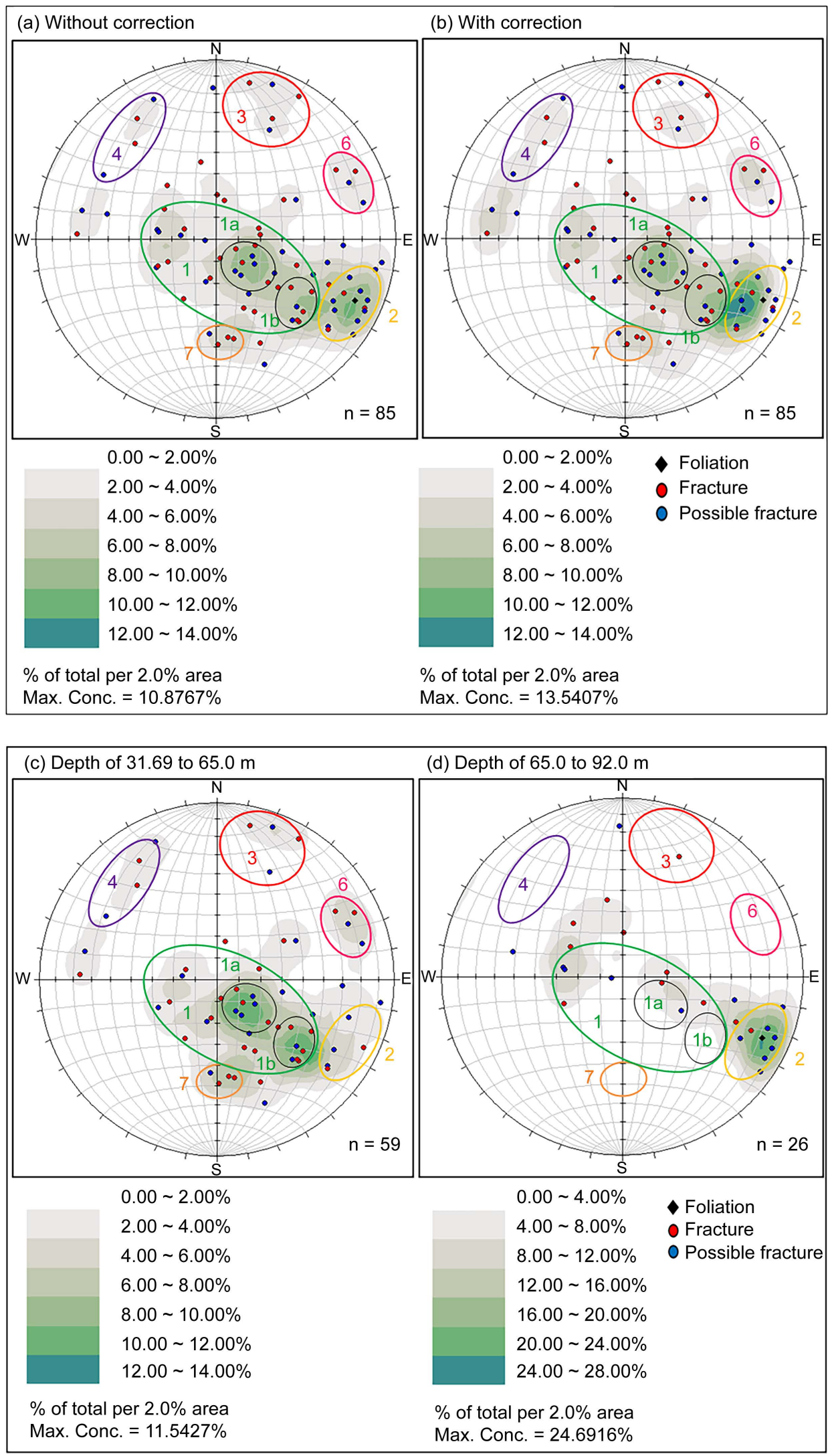

Figure 7. Polar projections of fracture planes present at borehole PP-02: (a) without Terzaghi correction; (b) with Terzaghi correction; (c) and (d) at different depths. 


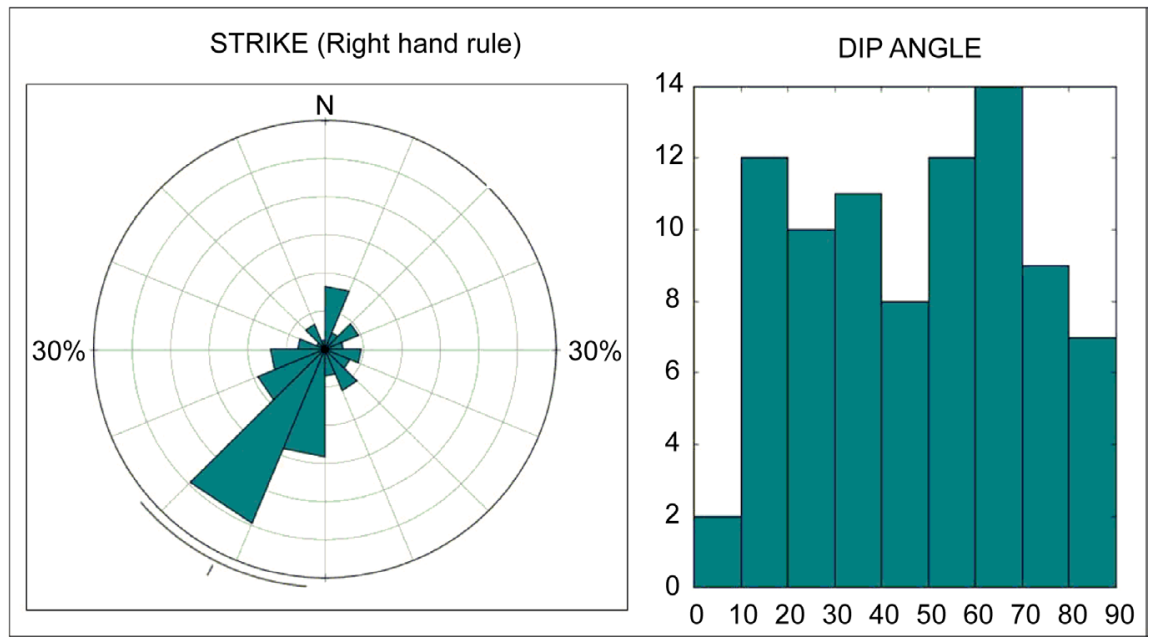

Figure 8. Statistics of strike and dip of fracture planes present at borehole PP-02.

to medium dip. However, NNE-SSW fractures dipping WNW predominate. It is the group with the highest density and lowest spacing, and it was possible to identify two areas where the density distribution is remarkable: the subgroup 1-a, characterized by low dip (up to $35^{\circ}$ ); and subgroup 1-b, with a little higher dips, between $40^{\circ}$ and $60^{\circ}$. As in the PP-01 borehole, Group 1 fractures in PP-02 occur more frequently in the upper dark-grey portion of the gneiss, but scattered fractures were observed until the bottom of the borehole. The application of the Terzaghi correction was more significant in the subgroup 1-b.

Group 2 fractures in the PP-02 are N-NE (N15-45E), dipping W to NW with higher angles, between $60^{\circ}$ and $85^{\circ}$. In stereograms with density contours drawn for the different depths (Figure 7 (c), Figure $7(d)$ ), it is clear the separation of the fractures of groups 1 and 2, since the two groups generally have the same strike, but different dips. The fractures of Group 2 are parallel to the foliation and, although they occur throughout the borehole, they are more frequent in the deepest portion of the borehole PP-02.

In a smaller number, Group 3 fractures are $\mathrm{N} 60-80 \mathrm{~W}$, dipping $>55^{\circ}$ to $\mathrm{SW}$, predominantly occurring in the upper dark-grey gneiss. Group 4 fractures are NE-SW, dipping $55^{\circ}-75^{\circ}$ to SE. Group 5 fractures were not identified in this borehole; however, two new fracture groups were defined: Group 6 are N10-30W/50-70SW and Group 7 EW/40-50N.

\subsection{Groundwater Sampling Using Straddle Packers}

Based on the fractures structural data gathered previously, three discrete intervals in each borehole were selected for collecting groundwater samples, through the use of straddle packers. The selected depths and the results of VOC concentrations are presented in Table 1.

In the PP-01 borehole, the groundwater sampling was conducted in the upper dark grey gneiss, which is more fractured. The VOCs analysis detected concentrations of the compounds 1, 1DCE, 1, 1DCA, 1, 2DCE and TCE above the 
Table 1. Volatile organic compounds (VOCs) concentrations in groundwater samples (in $\mu \mathrm{g} \cdot \mathrm{L}^{-1}$ ) obtained from discrete intervals in boreholes PP-01 and PP-02, using straddle packers.

\begin{tabular}{lccccccc}
\hline & PP-01A & PP-01B & PP-01C & PP-02A & PP-02B & PP-02C & \\
\cline { 1 - 5 } Depth (m) & $47.2-50.9$ & $53.1-56.8$ & $57.4-61.1$ & $36.2-39.9$ & $60.6-64.3$ & $84.5-88.2$ & $\begin{array}{c}\text { Cetesb } \\
2014^{\mathrm{a}}\end{array}$ \\
\cline { 1 - 5 } $\begin{array}{l}\text { Hydraulic head } \\
(\mathrm{m})(\mathrm{asl})\end{array}$ & 720.05 & 719.95 & 719.96 & 718.81 & 718.35 & 719.41 & \\
\hline PCE & 14 & 16 & 15 & $<1$ & $<1$ & $<1$ & 40 \\
TCE & 16 & 20 & 20 & 2.6 & $<1$ & 1.2 & 20 \\
1,2 DCE $($ sum $)$ & 138.5 & 187.9 & 180.8 & $<1$ & $<1$ & $<1$ & 50 \\
1,1 DCE & 29 & 36 & 33 & 9.5 & 5.1 & 3.2 & 30 \\
VC & $<1$ & $<1$ & $<1$ & $<1$ & $<1$ & $<1$ & 2 \\
$1,1,1$ TCA & $<1$ & $<1$ & $<1$ & $<1$ & $<1$ & $<1$ & 2000 \\
1,1 DCA & 102 & 135 & 139 & 1.9 & 1 & $<1$ & 53 \\
1,2 DCA & $<1$ & $<1$ & $<1$ & $<1$ & $<1$ & $<1$ & 10 \\
Toluene & 9.7 & 19 & 11 & 25 & 17 & 12 & 700 \\
\hline
\end{tabular}

a. Cetesb 2014 corresponds to the Sao Paulo State environmental standards. b. Asl = "above sea level". c. $\mathrm{DCM}=$ Dichloromethane. For other abbreviations, see item 2.2.

environmental standards in PP-01. The compounds PCE and toluene were also detected.

Concentrations of 1, 1DCA, 1, 1DCE, toluene and TCE were detected below standards in the PP-02 borehole. Considering the similarity between the concentrations of the compounds detected and the possibility of water samples represent mixtures of different depths during sampling, due to interconnection between the fractures in PP-02, it was not possible to confirm which of the depths sampled shows the highest concentrations of the contaminants.

\subsection{Evaluation of Groundwater Hydraulic Potentials and Flow}

The PP-01 borehole exhibited the main flow variations (water inlets and outlets) associated with the first 20 meters of rock (from 45 to $65 \mathrm{~m} \mathrm{bgs}$ ), where Group 1 fractures predominate. The highest observed velocities were $0.82 \mathrm{~m} \cdot \mathrm{min}^{-1}$ at 55.5 $\mathrm{m}$ and at $59.5 \mathrm{~m}$ depth (Attachment 1 ). There is also an expressive loss of water velocity between 53.0 and $51.0 \mathrm{~m}$, reaching $0 \mathrm{~m} / \mathrm{min}$. This variation can be attributed to the exit of water from the borehole through fractures identified at $52.0 \mathrm{~m}$ depth, which walls are weathered and with an apparent opening of 0.5 $\mathrm{cm}$, the largest in PP-01 associated to Group 1.

During the sampling activities, the hydraulic heads measured between the packers after head stabilization (Table 1) indicated a slightly vertical downward potential for the groundwater flow in the fractured aquifer $(9 \mathrm{~cm}$ of hydraulic head variation from 47.2 to $62.1 \mathrm{~m}$ ). However, variations in hydraulic potentials above the packers were observed during pumping at these three sampling 
depths, indicating that it was not possible to completely isolate the sampled intervals, even with the increase in the filling pressure of the packers. This interference may be due to the wall roughness of the borehole or the connection between the fractures in the rocky massif, especially those of high dip.

In PP-02, the fractures with larger apparent openings are spaced along the borehole, however, the higher flow velocities were also observed in the in the upper dark grey gneiss. The average velocities obtained in PP-02 were higher than those found in PP-01. The highest flow velocities were observed in the intervals between 32.0 and $38.1 \mathrm{~m}$ and from 61.0 to $62.0 \mathrm{~m}$ (Attachment 1). In the first section, Group 1 fractures predominate with dips $<60^{\circ}$ and the maximum measured velocity was $1.20 \mathrm{~m} / \mathrm{min}$. In the second interval, fractures of Group 3 and 4 predominate and the flow velocity was measured as $1.02 \mathrm{~m} / \mathrm{min}$.

The hydraulic heads measured in the borehole PP-02 above the packers did not change during the pumping for groundwater sampling at each depth, whereas, in the section between the packers, it was possible to observe a subtle variation, indicating a greater efficiency in the isolation of the sampled portion.

The hydraulic heads measured between the packers after head stabilization (Table 1) indicated a slightly vertical downward potential for the groundwater flow from level A to B ( $46 \mathrm{~cm}$ of hydraulic head variation from 36.2 to $64.3 \mathrm{~m}$ bgs) and a light upward potential for groundwater flow from level C to B $(6 \mathrm{~cm}$ of hydraulic head variation from 88.2 to $64.3 \mathrm{~m}$ bgs).

\subsection{Monitoring Wells and Hydraulic Tests}

After the groundwater sampling activities with the straddle packers, monitoring wells were installed at the intervals where the greatest velocity variations measured by the flowmeter and the highest VOC concentrations verified by sampling with the packers were verified. In the monitoring wells, the filter was installed in the depths of 50.8 to $54.8 \mathrm{~m}$ in PP-01 and from $35.3 \mathrm{~m}$ to $38.3 \mathrm{~m}$ in PP-02. In both wells, the rest of the boreholes underneath the filter depths was cemented.

After the well completion, they were developed and then recovery hydraulic tests were conducted in both wells. The analyzed intervals correspond to the permeable zone of the formation where the filters and prefilters were installed. Data were interpreted using the Hvorslev method [28]. The hydraulic conductivities obtained are $1.45 \mathrm{E}-6 \mathrm{~m} / \mathrm{s}$ for PP-01 and $5.34 \mathrm{E}-7 \mathrm{~m} \cdot \mathrm{s}^{-1}$ for PP-02.

A pumping test was conducted in the deep supply well P6, located $100 \mathrm{~m}$ far from the plume of contamination of the shallow aquifer in Area 1 (Figure 2), in order to evaluate the hydraulic connectivity of the deep fractured aquifer with the shallow water table aquifer of the industrial unit. During the pumping period, hydraulic heads of three monitoring wells installed in the water table aquifer were monitored: monitoring well MW 09B (109 m far from P6), MW 54 (17 $\mathrm{m}$ far from P6), and MW 34 (55 $\mathrm{m}$ far from P6), besides the new monitoring well PP-01 (91 m far from P6), with filter installed in the fractured aquifer (Figure 2). The pumping was carried out at a constant flow rate of $2.1 \mathrm{~m}^{3} \cdot \mathrm{h}^{-1}$ 
and lasted 11 hours and 20 minutes. Figure 9 shows the variation of water level depths measured in each of the monitoring wells.

Only monitoring well 54 , which is the closest to the pumping well P6, showed a clear influence of the pumping, with a hydraulic head variation of $0.37 \mathrm{~m}$. MW 54 presents a depth of $29.5 \mathrm{~m}$ and is installed in the water table aquifer, in the weathered bedrock and close to the contact with the hard fractured rock. Despite the short pumping time period, the test made it possible to confirm the connection between the aquifers and the rapid influence of the pumping of the deep supply well in the shallow wells, indicating that the fractures in the rock are hydraulically connected with the shallow aquifer at the base of the weathered bedrock.

\section{Hydrogeological Conceptual Model}

Figure 10 presents the hydrogeological conceptual model of the study area. The weathered bedrock of the gneiss rock is represented by a silt-clayey to silt-sandy material, with intercalations of quartz veins and clayey portions with discontinuities, which characterize it as a heterogeneous and anisotropic medium. The boreholes where located in the highest portions of the terrain and reached the top of the hard rock at $39.5 \mathrm{~m}$ in PP-01 and $30 \mathrm{~m}$ in PP-02.

The fractured aquifer is composed of two types gneisses below the weathering

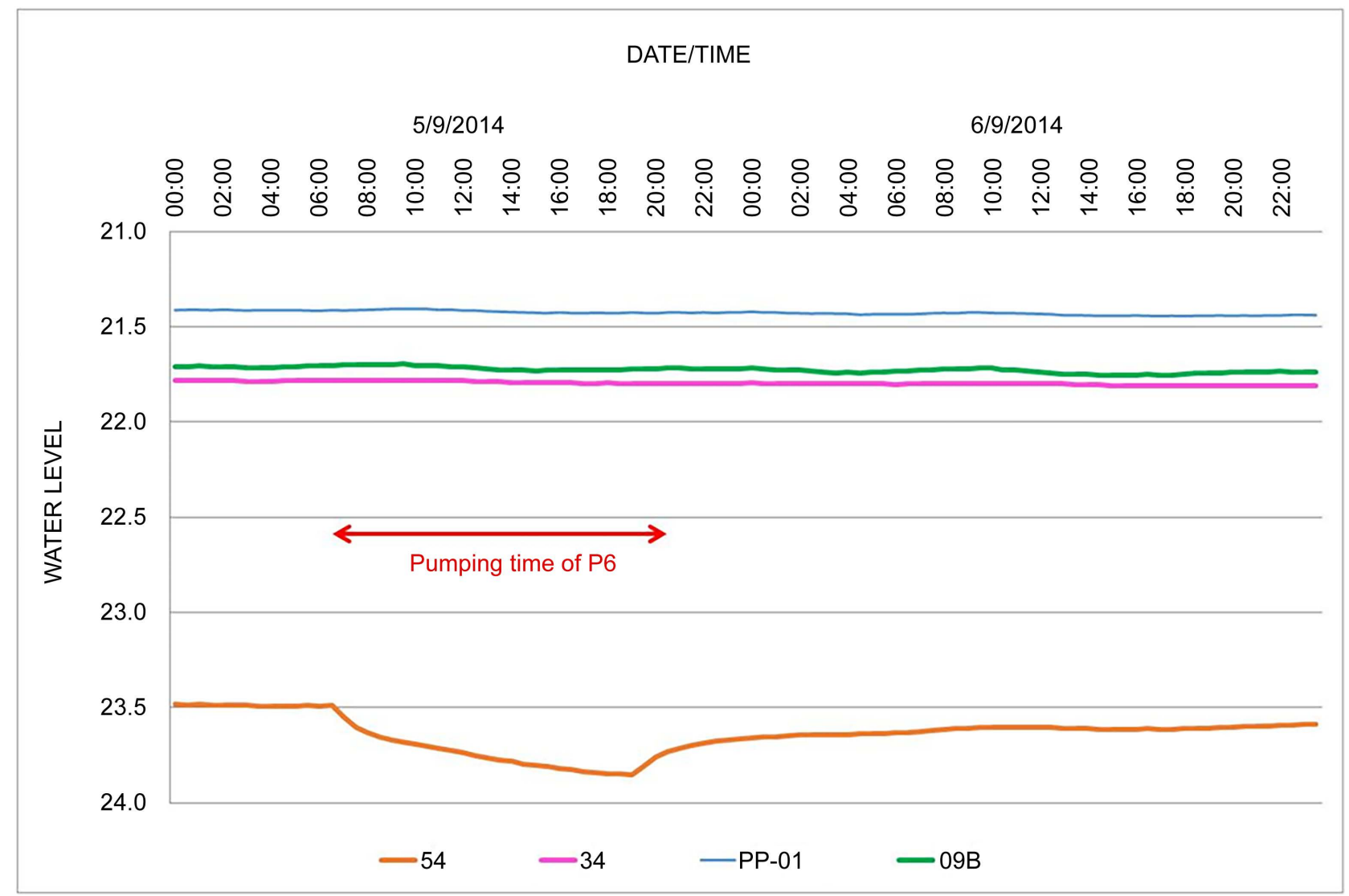

Figure 9. Variation of water level depths measured in the monitoring wells during the pumping test of deep supply well P6. 


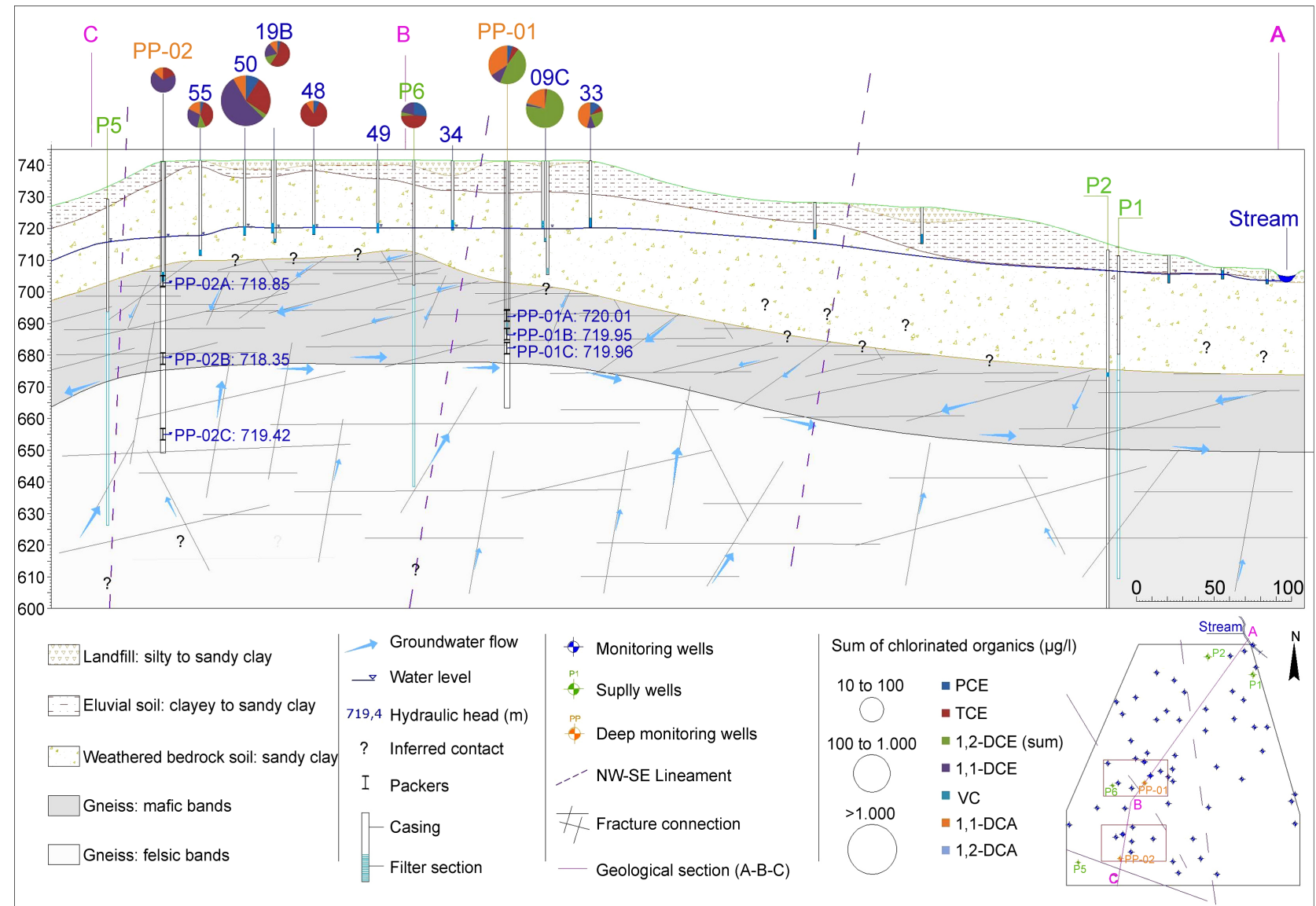

Figure 10. Hydrogeological conceptual model of the study area and identified chlorinated organic compounds in groundwater.

zone, one with predominance of mafic bands and other with felsic bands. From the top of the rock to the mean depth of $65 \mathrm{~m}$, the mafic portion of the gneiss predominates. This interval is quite fractured and weathered. The predominance of felsic bands in the gneiss, mainly composed of quartz, alkali feldspar and plagioclase, occurs from $65 \mathrm{~m}$.

Fractures with larger apparent openings and larger flow variations, verified in both boreholes, are generally those of low to medium dip, located in the first 25 meters of the weathered rock. They have a varied but predominant $\mathrm{N}$ to $\mathrm{NE}$ strike and were classified as Group 1. Group 2 fractures, with high dip angle, parallel to the foliation, are $\mathrm{N}$ to NE-SW dipping to $\mathrm{W}$ to NW and are, in general, more expressive in depth. Group 3 fractures are found throughout the entire PP-01 and also in the mafic portion of the PP-02 and present a medium to high dip, from E-W to NW-SE.

The presence of Group 1 fractures positioned mainly in the more superficial portion of the rock, intercepting fractures of medium to high dips, mainly of Groups 2, 3, 4 and 7, help in the hydraulic connection between the water table and the fractured aquifer, contributing for the migration of contaminants to deeper zones. Previous works on the fractured aquifer dynamics of the region [19] indicate that the fractures of NE to ENE and NNE are parallel to foliation 
and preferentially of distensive nature, being related to the main water conducting structures in the gneisses.

Hydraulic potentials measured during groundwater samplings with the straddle packers indicate the occurrence of a downward flow of water in the upper portion of the rock (up to approximately $65 \mathrm{~m}$ ) and an upward flow in the deepest portion. Despite the natural downward flow from the fractures of the upper portion of the rock, the influence of the supply wells pumping favored a faster migration of the plumes of contamination from the shallow aquifer into the fractured aquifer. The pumping of the supply well P6 and the declining of the water level of the well 54 is an indication of the hydraulic connection between the aquifers and the influence of the pumping of the supply wells in the shallow aquifer. Despite the similarity between the results of the chemical analyzes of the samples collected with the packers, the presence of dissolved chlorinated compounds was confirmed in both boreholes, with higher concentrations in PP-01.

When comparing the lineament traces that cross the study area with the occurrence of the contaminants observed, it is possible to identify a relationship between the compounds in the groundwater with the monitoring wells located in the same structural region, among the identified lineaments. The contamination observed in P6 is more similar to that observed in Area 2, although it is closer to the plume of Area 1. Thus, it is possible to suppose that the water flow is influenced and controlled by the existing regional structures, which may be draining groundwater regionally.

\section{Conclusions}

This work presents the results of the investigations carried out in a fractured aquifer for the improvement of the conceptual model of the contamination by chlorinated solvents in an industrial unit. Unlike investigations of aquifers of primary porosity, the investigations in fractured aquifers involve the application of specific techniques in a sequence of achievements, starting with the geological and surface geophysics, which are the basis for the location of boreholes. In the borehole, geophysical logging procedures are used for the geological and structural characterization of the aquifer rocks. Flowmeter and straddle packers are then used to provide information on the groundwater flow characteristics, measure hydraulic heads, hydraulic properties of fractures and collection of discrete water samples for analysis. These data are then interpreted for the design of monitoring wells. Priority is then given to the long-term monitoring of those fractures that carry a greater mass of the contaminants. In this work, not all the techniques described in the literature were used, like straddle packers for determining transmissivity of fractures, especially due to financial and time restrictions.

However, the greatest possible amount of information of this nature is important for the decision making process for the management of contaminated areas [29], since they allow to identify if contamination exists in the fractured aquifer, 
where it moves to, what are the receptors to be protected, and types of intervention to be applied (e.g. the decision to stop or continue the pumping of neighboring water supply wells to avoid spreading contamination in the aquifer).

It often occurs that the complexity of fracture networks does not allow local data obtained with a single borehole to be extrapolated to the study area as a whole. Thus, the understanding of the path of contamination requires obtaining data from other borehole with the application of the maximum of proposed techniques, including the execution of more complex hydraulic tests, such as those of cross-borehole types. The minimum number of wells required for the execution of a suitable hydrogeological model depends on the importance of the properties and environmental resources to be protected, the existence of human and ecological receptors, the intensity and size of the contamination and the complexity of the geological environment. The evaluation of these variables in each case should be taken into account to define the amount of financial effort necessary to improve the conceptual model of the area of environmental interest.

\section{Acknowledgements}

The authors express special thanks to Daphne Pino, Marcos Bolognini Barbosa and Amélia J. Fernandes for their valuable contributions during the stages of fieldwork activities and data interpretation. And also to Waterloo Brasil ConsultingLtda and the anonymous industrial company that kindly authorized the use of the data for publication.

\section{References}

[1] Parker, B. (2007) Investigating Contaminated Sites on Fractured Rock using the DFN Approach. Proceedings at the USEPA/NGWA Fractured Rock Conference: State of the Science and Measuring Success in Remediation, Maine, 150-168.

[2] Parker, B., Cherry, J. and Chapman, S. (2012) Discrete Fracture Network Approach for Studying Contamination in Fractured Rock. AQUA mundi, Am06052, 101-116.

[3] Keys, S. (1990) Techniques of Water-Resources Investigations of the United States Geological Survey. USGS Report, 165 p. https://pubs.usgs.gov/twri/index090905.html

[4] Lane, J. (2002) An Integrated Geophysical and Hydraulic Investigation to Characterize a Fractured-Rock Aquifer. U.S. Department of the Interior, U.S. Geological Survey, Norwalk, 97 p. https://water.usgs.gov/ogw/bgas/publications/wri014133/

[5] Lau, J., Auger, L. and Bisson, J. (1987) Subsurface Fracture Surveys using a Borehole Television Camera and Acoustic Televiewer: Reply. Canadian Geotechnical Journal, 24, 499-508. https://doi.org/10.1139/t87-066

[6] Cruden, D. (1988) Subsurface Fracture Surveys using a Borehole Television Camera and Acoustic Televierwer: Discussion. Canadian Geotechnical Journal, 25, 843. https://doi.org/10.1139/t88-094

[7] Morin, R., Godin, R., Nastev, M. and Rouleau, A. (2007) Hydrogeologic Controls Imposed by Mechanical Stratigraphy in Layered Rocks of the Chateauguay River Basin, a US-Canada Transborder Aquifer. Journal of Geophysical Research, 112, B04403. 
[8] Robinson, D., Binley, A., Crook, N. and Slater, L. (2008) Advancing Process-Based Watershed Hydrological Research using near Surface Geophysics: A Vision for, and Review of, Electrical and Magnetic Geophysical Methods. Hydrological Process, 22, 3604-3635. https://doi.org/10.1002/hyp.6963

[9] Francese, R., Mazzarini, F., Bistacchi, A., Morelli, G., Pasquare, G., Praticelli, N., Robain, H., Wardel, N. and Zaja, A. (2009) A Structural and Geophysical Approach to the Study of Fractured Aquifers in the Scansano-Magliano in Toscana Ridge, Southern Tuscany, Italy. Hydrogeology Journal, 17, 1233-1246. https://doi.org/10.1007/s10040-009-0435-1

[10] Paillet, F. (1995) Using Borehole Flow Logging to Optimize Hydraulic Test Procedures in Heterogeneous Fractured Aquifers. Hydrogeology Journal, 3, 4-20. https://doi.org/10.1007/s100400050249

[11] Day-Lewis, F., Johnson, C., Paillet, F. and Halford, K. (2011) A Computer Program for Flow-Log Analysis of Single Holes (FLASH). Groundwater, 49, 926-931. https://doi.org/10.1111/j.1745-6584.2011.00798.x

[12] Johnson, C., Mondazzi, R. and Joesten, P. (2009) Borehole Geophysical Investigation of a Formerly Used Defense Site, Machiasport, Maine, 2003-2006. USGS Scientific Investigations Report 5120, 87 p. https://pubs.usgs.gov/sir/2009/5120/pdf/sir2009-5120_text_508.pdf

[13] Lapcevic, P. (1988) Results of Borehole Packer Tests at the Ville Mercier Groundwater Treatment Site. NWRI Contribution 88, RRB-88-92. National Water Research Institute Canada Centre for Inland Waters, Burlington, $30 \mathrm{p}$.

[14] Novakowski, K., Bickerton, G., Lapcevic, P.V.J. and Ross, N. (2006) Measurements of Groundwater Velocity in Discrete Rock Fractures. Journal of Contaminant Hy drology, 82, 44-60.

[15] Wahnfried, I. (2010) Hydrogeologycal Conceptual Model of the Serra GeralAquitard and Guarani Aquifer in RibeirãoPreto, São Paulo, Brazil. Doctoral Thesis, Institute of Geosciences, University of Sao Paulo, Sao Paulo. (In Portuguese) http://www.teses.usp.br/teses/disponiveis/44/44138/tde-07072010-163245/publico/I W.pdf

[16] Quinn, P., Parker, B. and Cherry, J. (2011) Using Constant Head Step Tests to Determine Hydraulic Apertures in Fractured Rock. Journal of Contaminant Hydrology, 126, 85-99.

[17] Quinn, P., Cherry, J. and Parker, B. (2011) Quantification of Non-Darcian Flow Observed during Packer Testing in Fractured Sedimentary Rock. Water Resources Research, 47, 15 p. https://doi.org/10.1029/2010WR009681

[18] Quinn, P., Cherry, J. and Parker, B. (2012) Hydraulic Testing using a Versatile Straddle Packer System for Improved Transmissivity Estimation in Fractured-Rock Boreholes. Hydrogeology Journal, 20, 1529-1547. https://doi.org/10.1007/s10040-012-0893-8

[19] IG-SMA, InstitutoGeológico (1993) Aids of the Geological Physical Environment to the Planning of Campinas Municipality (Brazil). Technical Report, Volume II, Sao Paulo. (In Portuguese)

[20] Almeida, F., Hassui, Y., Brito Neves, B. and Fuck, R. (1977) Structural Brazilian Provinces. Proceedings at the 8 th SBG Northeast Geology Symposium, Campina Grande.

[21] Vaz, L. (1996) Genetic Classification of Soils and Weathered Rock Horizons in Tropical Regions. Solos e Rochas, 19, 117-136. (In Portuguese) 
[22] Waterloo Brasil (2011) Geological Study and Top of Bedrock Mapping. Technical Report, Confidential, São Paulo.

[23] Fernandes, A. (1997) Cenozoic Tectonics of the Piracicaba River Basin and Its Application to Hydrogeology. Doctoral Thesis, Institute of Geosciences, University of Sao Paulo, Sao Paulo. (In Portuguese)

http://www.teses.usp.br/teses/disponiveis/44/44133/tde-30092013-163243/pt-br.php

[24] Pankow, J. and Cherry, J. (1996) Dense Chlorinated Solvents and Other DNAPLs in Groundwater: History, Behaviour and Remediation. Waterloo Press, Oregon, 525 p.

[25] Kueper, B., Weathall, G., Smith, J., Leharne, S. and Lerner, D. (2003) An Illustrated Handbook of DNAPL Transport and Fate in the Subsurface. Vol. 133, R\&D Publication, 67.

http://eprints.whiterose.ac.uk/90412/1/DNAPL\%20handbook\%20final.pdf

[26] Terzaghi, R. (1965) Sources of Error in Joint Surveys. Géotechnique, 15, 287-304. https://doi.org/10.1680/geot.1965.15.3.287

[27] Pino, D. (2012) Structural Hydrogeology in the Kenogamy Uplands, Quebec, Canada. MSc Thesis, L’Université du Québec, Chicoutimi. http://constellation.uqac.ca/2572/1/030329562.pdf

[28] Hvorslev, M. (1951) Time Lag and Soil Permeability in Ground-Water Observations, Waterways Exper. Sta. Corps of Engrs, U.S. Army, Vicksburg. http://www.csus.edu/indiv/h/hornert/geol_210_summer_2012/week\%203\%20readi ngs/hvorslev\%201951.pdf

[29] Barbosa, M., Bertolo, R.A. and Hirata, R. (2017) A Method for Environmental Data Management Applied to Megasites in the State of Sao Paulo, Brazil. Journal of Water Resource and Protection, 9, 322-338. https://doi.org/10.4236/jwarp.2017.93021 


\section{Attachment 1}

PP-01
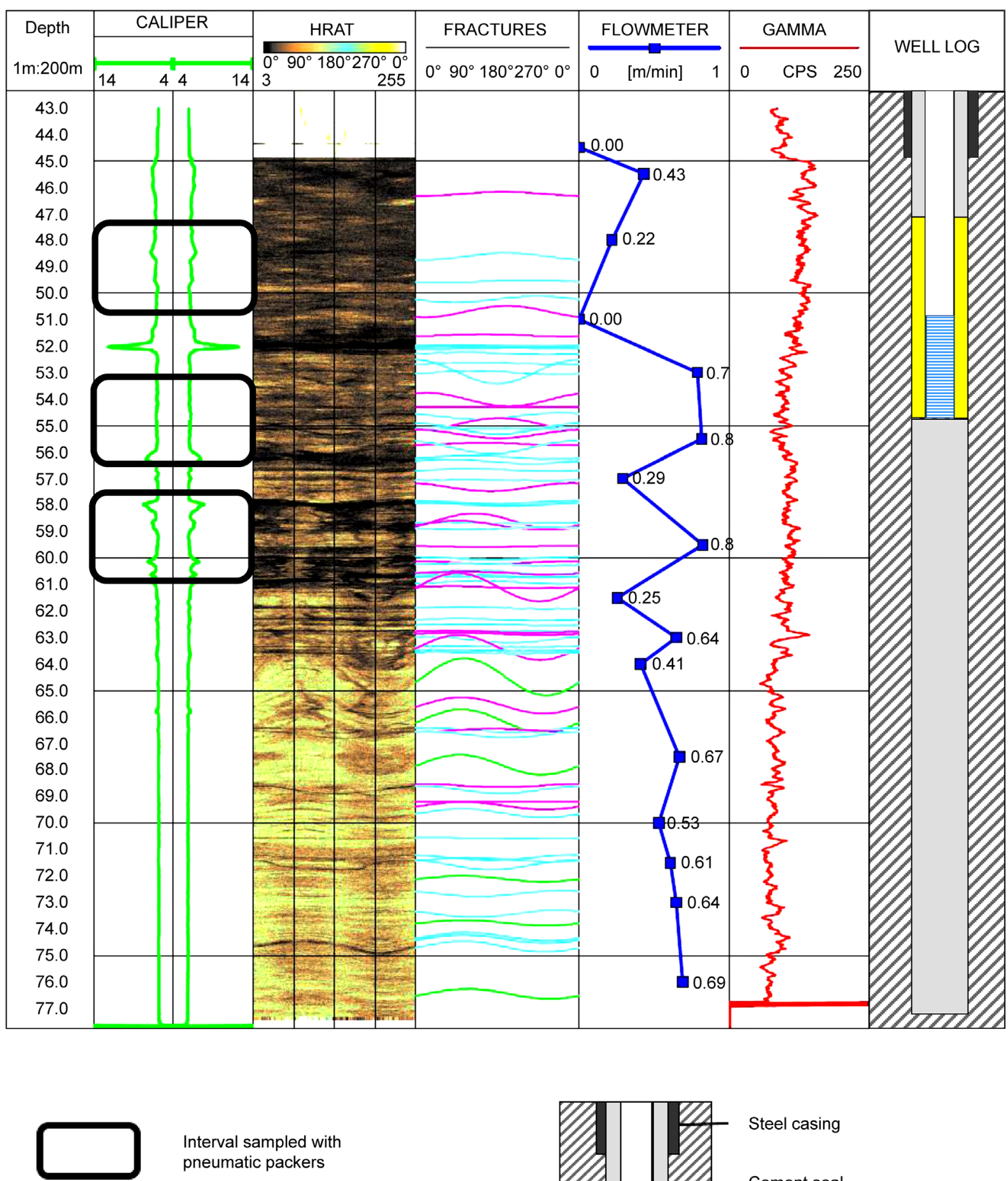

Interval sampled with

pneumatic packers
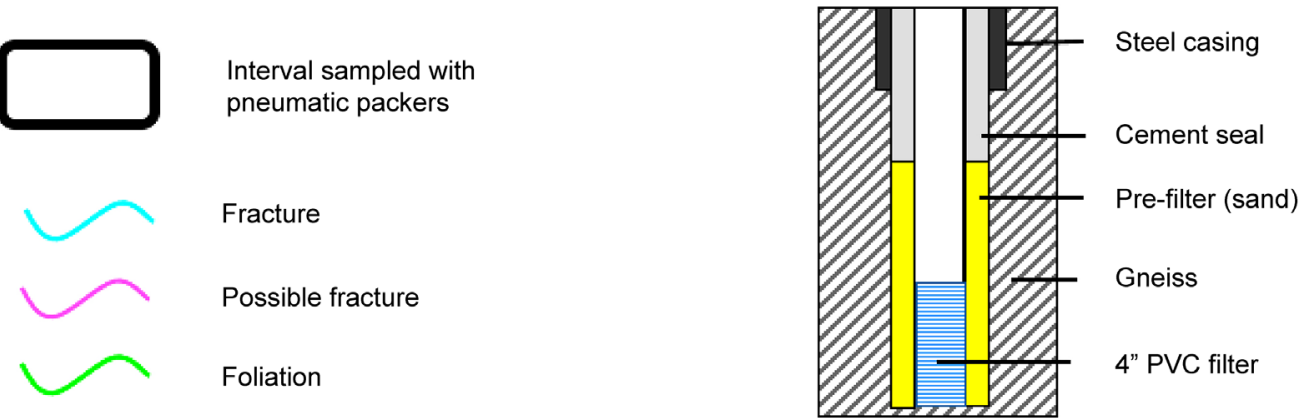
PP-02

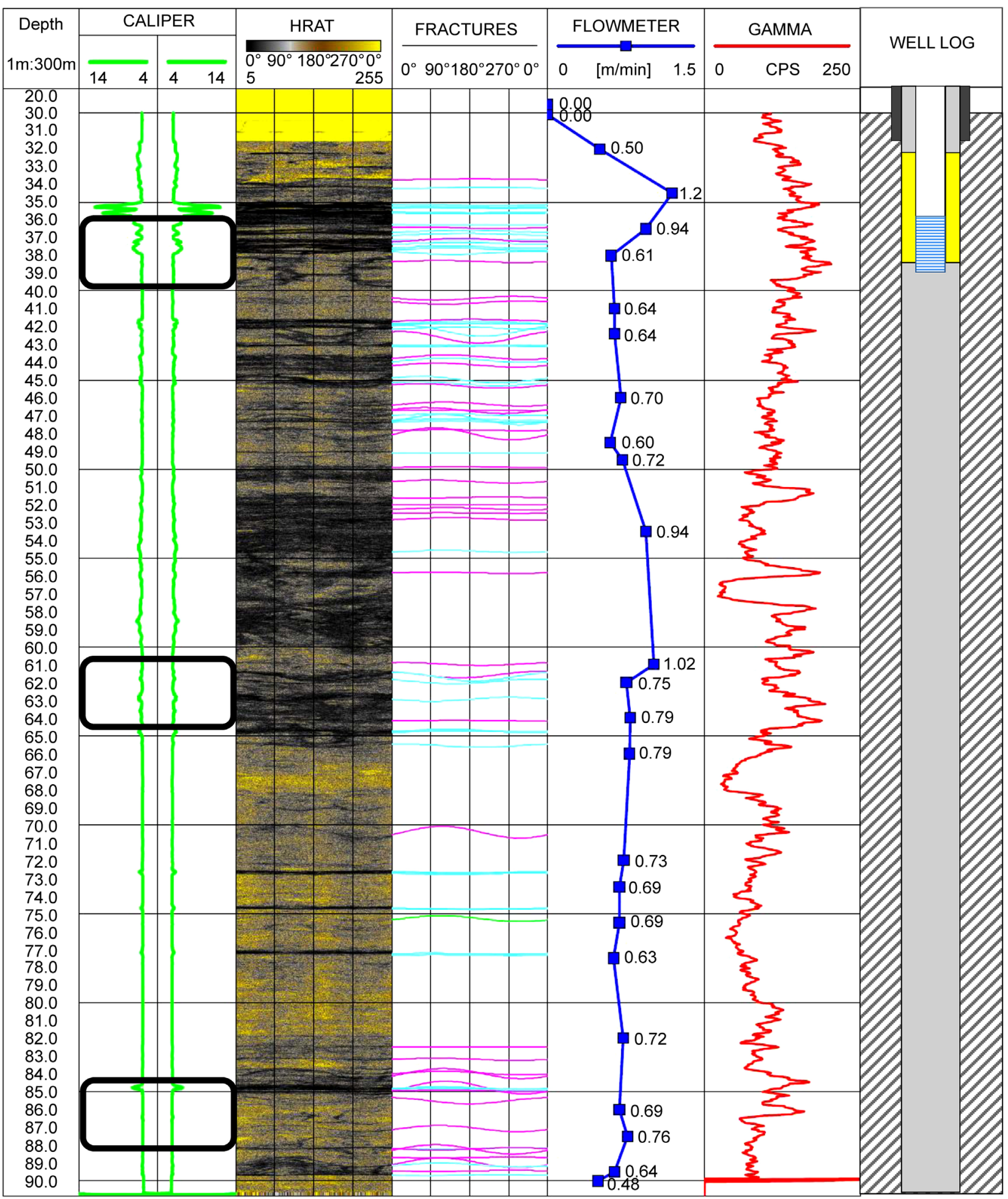

PP-01 and PP-02. Two deep monitoring wells (inserting PP-01 and PP-02). 
Submit or recommend next manuscript to SCIRP and we will provide best service for you:

Accepting pre-submission inquiries through Email, Facebook, LinkedIn, Twitter, etc. A wide selection of journals (inclusive of 9 subjects, more than 200 journals)

Providing 24-hour high-quality service

User-friendly online submission system

Fair and swift peer-review system

Efficient typesetting and proofreading procedure

Display of the result of downloads and visits, as well as the number of cited articles Maximum dissemination of your research work

Submit your manuscript at: http://papersubmission.scirp.org/

Or contact jwarp@scirp.org 


\title{
A Method for Environmental Data Management Applied to Megasites in the State of Sao Paulo, Brazil
}

\author{
Marcos Barbosa, Reginaldo A. Bertolo, Ricardo Hirata \\ University of Sao Paulo-USP, Instituto de Geociências, Sao Paulo, Brazil \\ Email: bertolo@usp.br
}

How to cite this paper: Barbosa, M., Bertolo, R.A. and Hirata, R. (2017) A Method for Environmental Data Management Applied to Megasites in the State of Sao Paulo, Brazil. Journal of Water Resource and Protection, 9, 322-338.

https://doi.org/10.4236/jwarp.2017.93021

Received: December 9, 2016

Accepted: February 25, 2017

Published: February 28, 2017

Copyright $\odot 2017$ by authors and Scientific Research Publishing Inc. This work is licensed under the Creative Commons Attribution International License (CC BY 4.0).

http://creativecommons.org/licenses/by/4.0/

\begin{abstract}
The management of contaminated areas with multiple sources of contamination (megasites) is among the biggest challenges for the Brazilian environmental agencies, especially because aquifers in big urban areas, like the Sao Paulo Metropolitan Region, are important sources of water for human supply purposes. One of the main reasons that hamper the proper management of urban environmental problems is a lack of a unified system where all information can be easily integrated into regional studies. To address this problem, a method for data integration and management using a Geographic Information System (GIS) was developed. This method was applied to the case of a regional contamination of an aquifer by chlorinated solvents at a former industrial district in Sao Paulo city, named Jurubatuba, but the final product might also be used for data management of contaminated areas for the entire State of Sao Paulo. The main result obtained was that the site-by-site approach for aquifer contamination management is ineffective. Furthermore, there are many other suspected and potential sources of contamination without any information available after more than 10 years since the contamination problem was discovered at the FIZ 131.
\end{abstract}

\section{Keywords}

Megasite, Chlorinated Organics, Geographic Information System

\section{Introduction}

The regional contaminations of aquifers, also known as megasites, are zones that comprehend multiple contamination sources and multiple legal responsible parties [1]. The environmental management of these areas represents a great challenge for all stakeholders involved. They are the regulatory agencies, the legal responsible 
for the contaminated land (usually the owner of the property), technicians and members of the society among others. The management process is usually marked by the lack in communication due to the existence of distinct and antagonistic interests between the parties [2].

Several cases of megasites contamination have resulted in the development of environmental management methodologies [1] [3] [4] [5] [6] [7]. These methodologies usually make use of a risk based assessment for resources allocation to mitigate the impacts to specific assets or communities to be protected. All these projects have one thing in common, the development and application of Geographic Information Systems (GIS). These are tools to support the implementation of an integrated information management strategy, such as SMARTe [8], DECERNS [9] and those developed by Ascough et al. [10] and Malczewski [11].

These methodologies of data integration using GIS applied to the management of environmental problems are still under development in Brazil, which is not a big issue when dealing with contamination liabilities at individual site scale. However, when dealing with megasites and regional contamination, it is very difficult to establish a link between concentrations of pollutants in groundwater and a given legal responsible for the source of contamination. This scenario is aggravated by the existence of commingled plumes, many times involving dense non-aqueous phase liquids (DNAPL), and complex hydrogeological scenarios, like fractured bedrock aquifers. This is the case of the Jurubatuba district, a former industrial area located in Sao Paulo city, Brazil (Figure 1). The area has presented a legacy of environmental liabilities due to intense industrial occupation in the last decades and inappropriate handling of chlorinated solvents has led to contamination of the fractured bedrock aquifer.

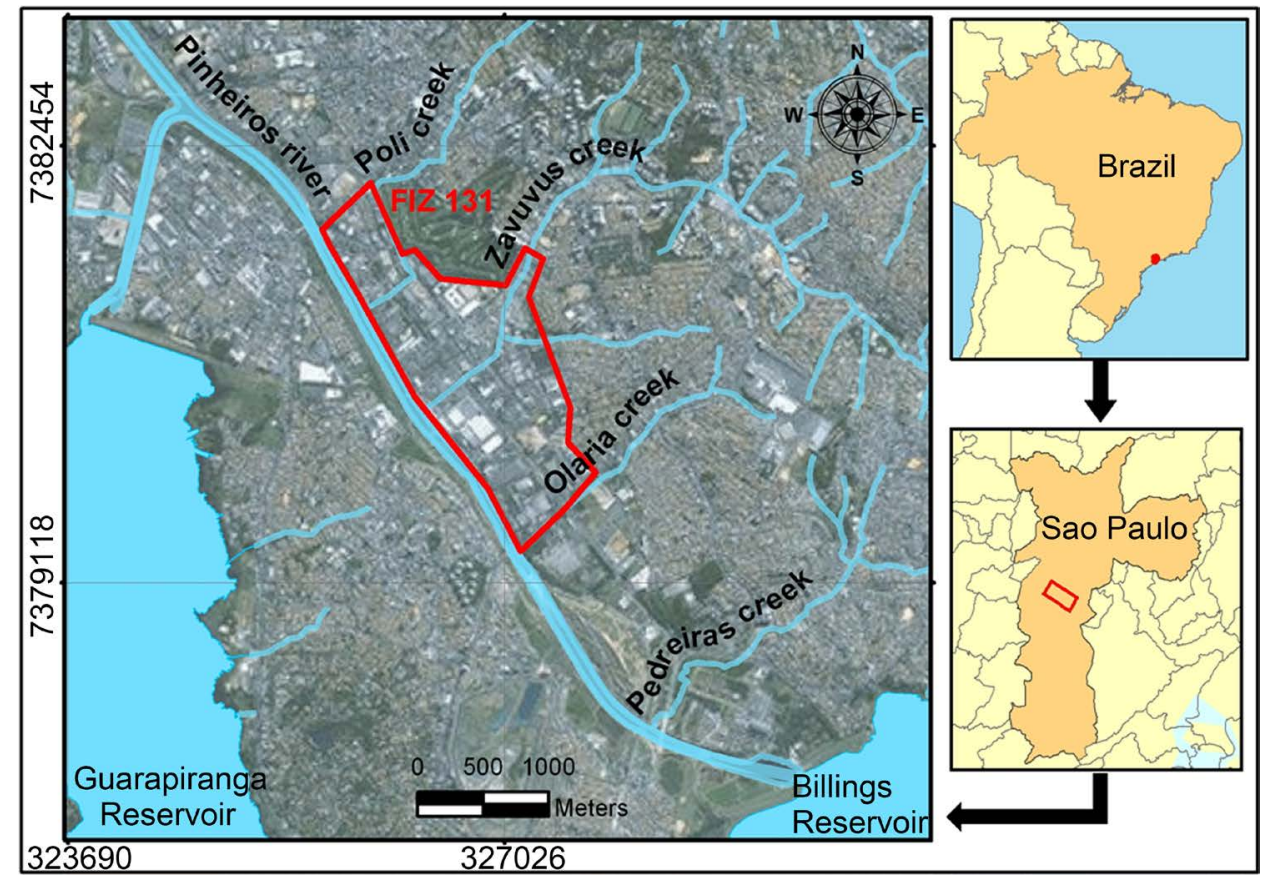

Figure 1. The study area in Sao Paulo city (FIZ 131 area), a subarea of the Jurubatuba district. 
The environmental agency of Sao Paulo state (CETESB) has an information system for potential sources of pollution which is used to register contaminated sites, but it contains only cadastral and licensing information. All the data related to environmental studies and historic evolution of the sites are stored in physical files, electronic PDF files or spreadsheets. Each of these materials is separated in individual records, making the information fragmented and inaccessible.

In order to develop the management of megasites in Sao Paulo, it is necessary to exchange the current approach being used, of managing each contaminated site (or land property) separately. Instead, in these areas of high density of potential sources of contamination, the extension of the plumes should be the focus. In this way, the whole process of denial of the impact and exemption from liability by the polluters is inhibited.

The international experience demonstrate that the creation of a GIS applied to the management of contaminated sites is fundamental to advance this process. The transition to this approach is laborious and complex, but it can be facilitated by software and tools that are already consolidated. Therefore, data can be integrated with external databases and incorporate numerical modeling of flow and transport of contaminants [2] [12].

The objective of this work was to develop a method for integration of environmental data for soil and groundwater contamination using a GIS-based system. This method was applied on a pilot scale to a subarea of the Jurubatuba case [13], the Former Industrial Zone 131 (FIZ 131). This methodology can later be applied by the environmental authorities to improve the management of all contaminated sites.

\section{Study Area}

The industrial district at the former FIZ 131 area started in the early 1950's but the development process was more intense on the 1970's. The area was occupied by medium to large industries from diverse sectors, such as chemical, metallurgic and car industries, among others [14]. In 2004, a specific municipal directive extinguished the Industrial Zones in the city of Sao Paulo that became classified as mixed use zones (residential, commercial and industrial). Since then, the FIZ 131 has undergone on an accelerated process of redevelopment. The legacy of environmental liabilities left by the industries has put human receptors at risks, as the old buildings have given rise to residential complexes, commercial offices and services. The main groups of contaminants impacting groundwater are chlorinated ethenes, ethanes and methanes, which were found in several supply wells with depths of up to $300 \mathrm{~m}$.

Historically, groundwater has been used mostly by industries in production and for sanitary purposes [13]. It is estimated that more than $70 \%$ of the supply wells operate illegally in the region and there is little or no control over their exploitation conditions [15]. Most of the wells exploit the fractured Crystalline Aquifer System, constituted by Precambrian metamorphic rocks (gneiss, schist) [16]. However, there are wells that also exploit the Sedimentary Aquifer System (Ceno- 
zoic sediments, associated to the Sao Paulo Sedimentary Basin).

The environmental agency initiated more effective actions in order to identify and control the environmental liabilities of soils and groundwater in the region in 2001. The leading edge was one of the local industries that reported the presence of high concentrations of chlorinated solvents in soil and groundwater inside their property [14]. With the identification of other sources of contamination and plumes crossing the boundaries of properties, the environmental agency began to monitor the quality of groundwater withdrawn from supply wells. The confirmation of the widespread presence of chlorinated solvents in dozens of deep supply wells came in the first regional campaign. This lead to the creation of a groundwater "Zone of Restriction of Use" instituted by a state water resources agency in 2005.

To better understand the extension of the impacts in the supply wells and the Crystalline Aquifer System, a regional study was later conducted to assess the quality of groundwater and the production capacity of the existing wells. This study comprised a review of several aspects of the Jurubatuba district with respect to potential sources of pollution, land use, geology and hydrogeology [13]. However, the data used for assessing groundwater quality was limited to few samples collected in the supply wells available. Thus, a new restriction and control zone was created which is maintained until now [17].

The current restriction zone is divided into three levels of restriction (high, medium and low), where drilling of new wells are not allowed in any of them. If the detection of chlorinated organics is confirmed in any of the operating supply wells, it should be immediately decommissioned. Wells that do not indicate the detection of these compounds should be monitored quarterly in high and medium restriction zones and semi-annually in the low restriction zones. Illegal wells must be identified to receive the concession, while decommissioning is mandatory in cases of abandoned supply wells. The restriction zone is a useful institutional measure, avoiding receptors to get in contact with contaminated groundwater. However, this measure does not have any effect on the reduction of contaminant mass in the aquifer or the sustainable use of groundwater.

Despite all the performed studies at FIZ 131 over the past 15 years, little has advanced for the solution of the regional environmental problem. This is due to environmental assessments limited to individual known source areas which rarely comprised the crystalline aquifer. So far, studies have not attempted to integrate data from different sites into a single database.

\section{Methodology}

The first step to integrate data was the selection of a Geographic Database (GDB) model, a relational database that supports geometric features and its customization. The File Geodatabase was adopted to store spatial data [18], this is a standard relational database management system for tables and attributes information. The model adopted was the Arc Hydro Groundwater data model [19], which facilitates the process of database customization. The model includes the representation of 
geological, hydrogeological, hydroestratigraphic, soil boring, wells and time series. The GDB implementation contemplated several activities which were described in Strassberg et al. [18] to develop the database structure and relationships which were modified to the FIZ 131 needs and presented in Figure 2, where feature classes and relationships that were adopted to the framework data model are presented.

Data acquisition was made through the state environmental agency (Cetesb) files, referring to the processes of contaminated sites located in the former FIZ 131 area. Data from supply wells were obtained at the state water resources agency DAEE. The data acquisition was also complemented by research on literature, such as academic papers and theses [15] [20] [21]. Raw data was preferably imported into the GDB. The reliability assessment of the data collected by fieldworkers was not part of the scope of this work.

The identification of current property owners and activities were made by door to door survey, on line research, environmental pollution registry database and reports of contaminated sites. Areas not related to the use of solvents in the past are considered of low potential of contamination. Those properties associated with the use of solvents were considered potentially contaminated. In the case of known use of solvents, the properties were considered suspected of contamination. When there were no records of previous activities, the area was classified as unknown. All known contaminated sites listed by the environmental agency were registered as contaminated.

The registration of the contaminated areas was done based on the "List of contaminated and rehabilitated areas", available at the environmental agency and referred to the year 2014 [22]. From the files, the processes to be evaluated were selected. Among the information collected, the following stand out: location of soil borings and wells, well and lithological logs, hydraulic tests, hydrogeological cross-sections, soil and water chemical analysis, soil and water physical properties.

Supply wells information was obtained from the licensing processes available in the water resources agency (DAEE), accessed in 2013. These were complemented with some of the illegal wells data available [21] and contaminated sites reports. Lithological and well construction information, location and chemical analysis

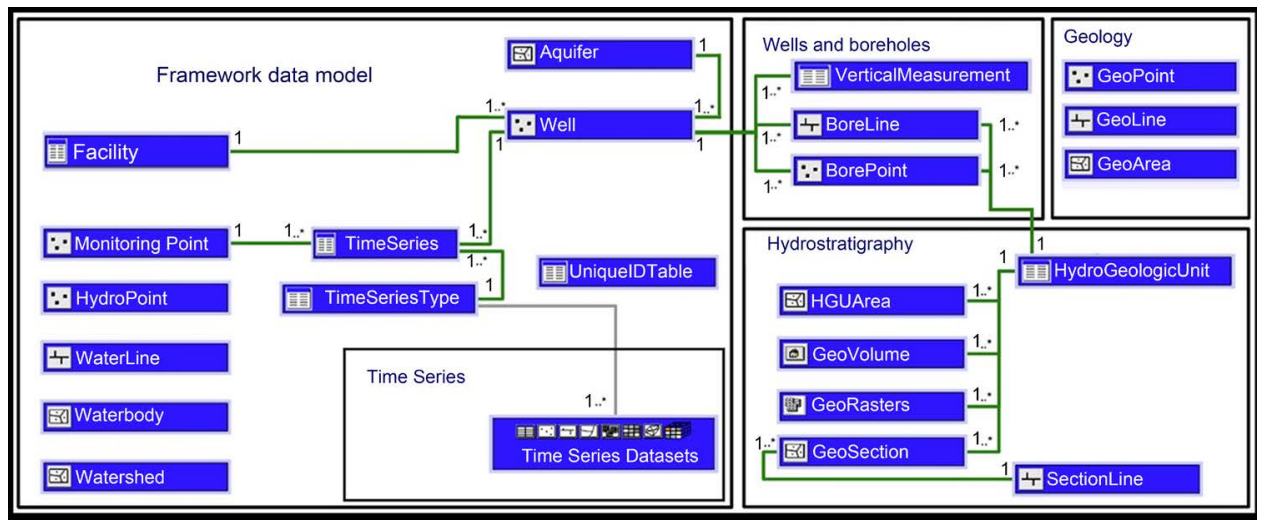

Figure 2. Geodatabase structure implemented at the FIZ 131 [19]. 
were the most important data selected.

Lithological data were found to be very heterogeneous on the way they were presented in the reports accessed. Prior to import data into the GDB, they had to be reclassified in generic groups using texture classes [23]. Four lithological groups were adopted for classification purposes, technogenic deposits, sediments (Quaternary and Tertiary origin), saprolite and hard rock. The original $\log$ description was maintained in a database field to facilitate a possible reclassification or new interpretation in cases of disagreement or doubt.

The verification and adjustment of geographic location (coordinates and elevation) was performed by a topographic survey campaign that was carried out in a series of monitoring wells located on public areas. They were used as a reference for the wells inside the contaminated sites which were not accessible. The planimetric coordinates adopted were the SIRGAS 2000 system and the orthometric elevation was obtained through the IBGE MapGeo 2010 geoidal model.

After the systematization of all the information in the database, cartographic products were prepared. The first part of this activity consisted in the spatial representation of the data, resulting in characterization maps of the physical environment. The second part consisted in the interpretation of products based on the relation of data for the management of contaminated areas (e.g. map of priority areas to be investigated).

\section{Results}

The material assessed for data integration included 220 reports of contaminated sites, 35 supply wells licensing reports, 4 academic reports as well as geographic information developed by public agencies available online (city infrastructure data, geology, hydrography, land use, groundwater restriction area, among others). The visualization of these data allowed a better analysis of the regional contamination management. Due to the high amount of data constantly generated, a working method was developed (Figure 3). This working method is presented in a flow chart format that describes the steps to acquire the relevant data, process and import them into the GDB. To date, 189 properties have been registered, 1219 wells (1011 monitoring, 109 sampling, 64 remediation and 35 supply), 10684 water level data, 93313 groundwater chemical analysis data and 175 hydraulic tests. Despite all this data, essential aspects needed for understanding the regional problem remain poorly understood.

\subsection{Properties Characterization}

From the 189 properties registered, 21 are contaminated sites, where 13 are by chlorinated solvents, 12 already used solvents and 41 had activities related to the use of solvents. Although practically all the properties have been registered in the database, almost half do not present any information about past activities. This may be an underestimate number of suspected and potentially contaminated sites. Based on the historical records of use of solvents, it was possible to indicate priority areas for investigating groundwater (Figure 4). The criterionwas based on the proximity to contaminated sites, suspected or with potential of contamination. 


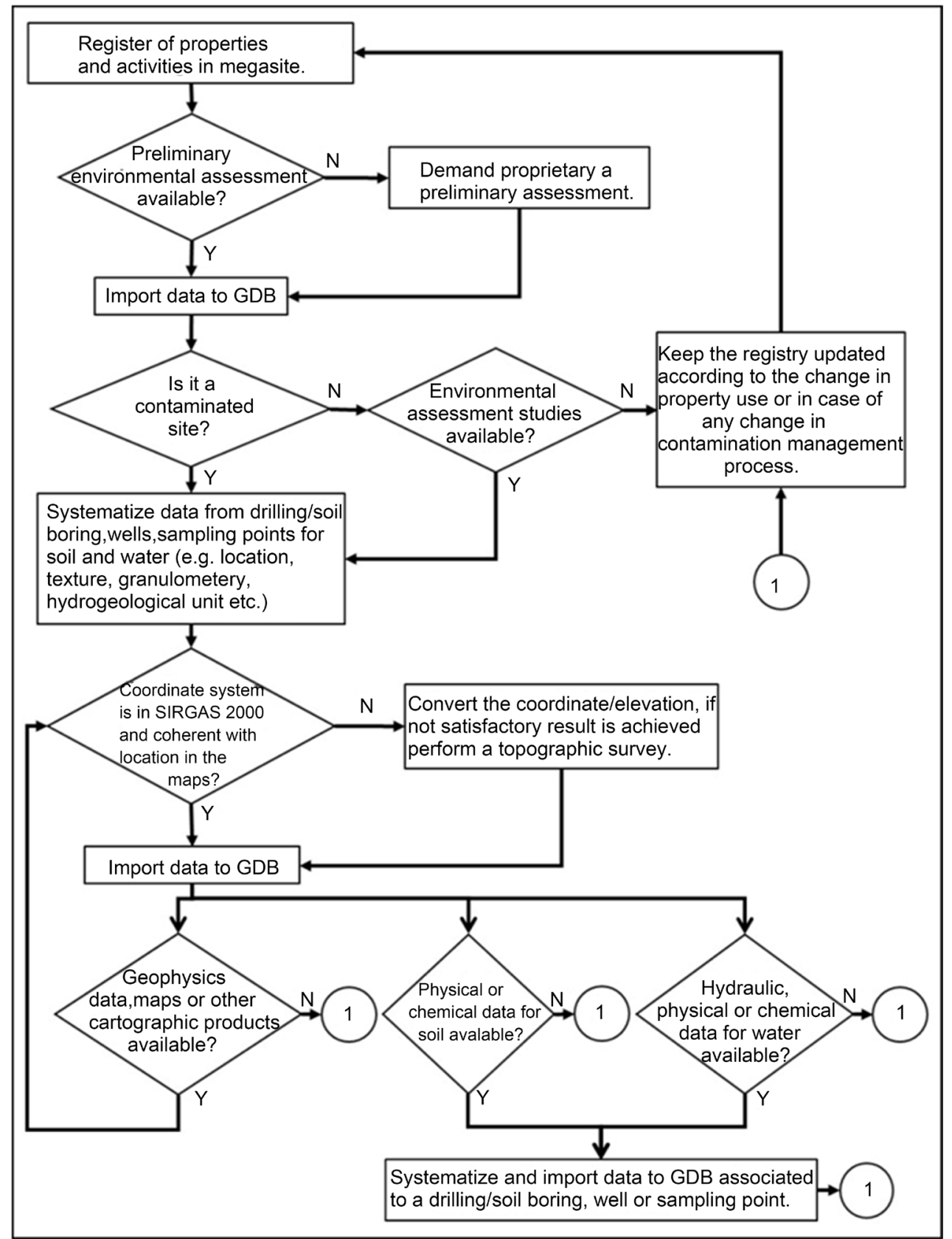

Figure 3. Data management process for importation into the GDB.

The FIZ 131 presents a total area of $2.6 \mathrm{~km}^{2}$. The priority areas for investigation comprise approximately $0.8 \mathrm{~km}^{2}$, while the properties which present some degree of environmental investigation sum an area of approximately $0.7 \mathrm{~km}^{2}$. Poor data distribution and existence of large areas without any information draws attention. Therefore, despite all the effort from the environmental agency since 2001, one third of its coverage remains unknown with regard to the existence of other sources of contamination.

\subsection{Geological and Hydrogeological Characterization}

Although there are more than a thousand lithologic logs of soil borings which 


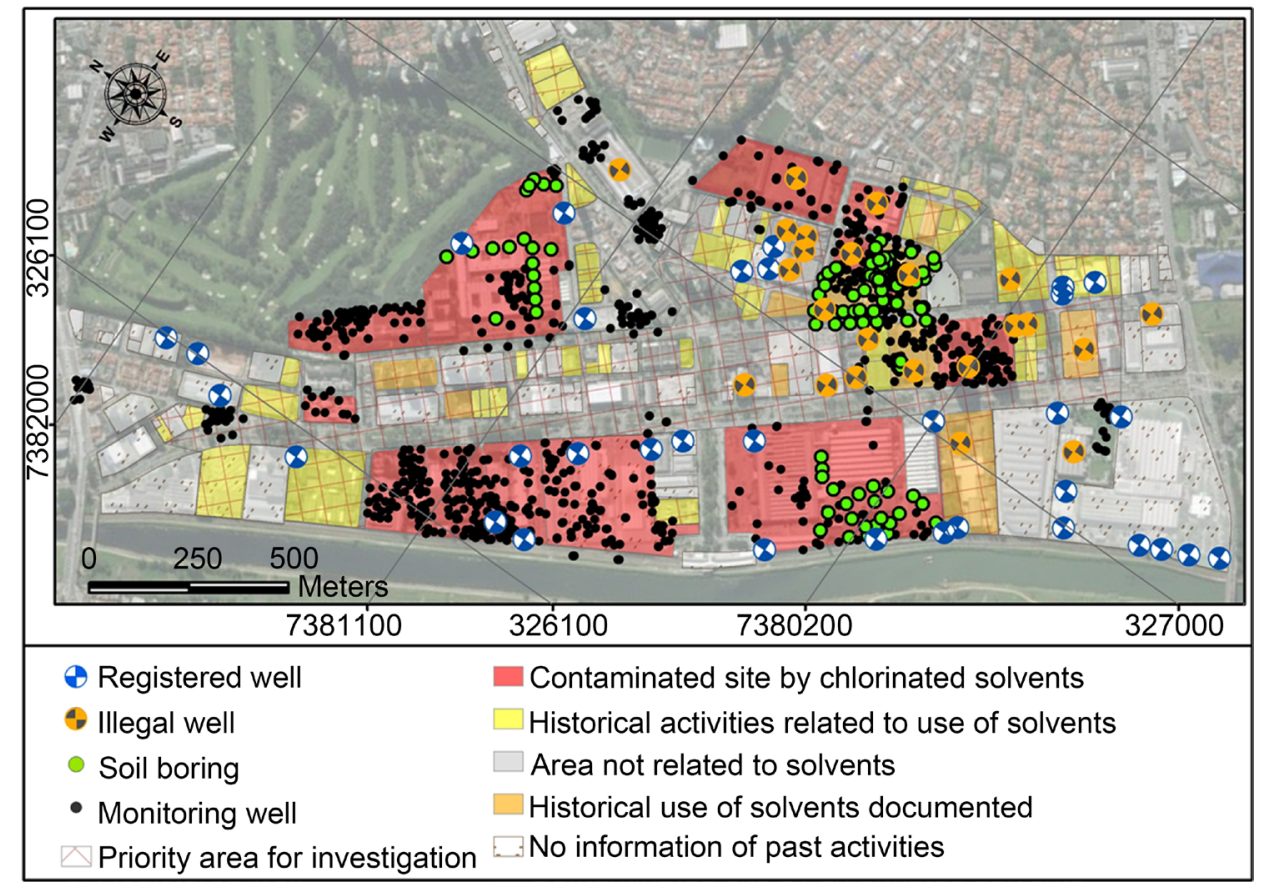

Figure 4. Priority areas for groundwater quality investigation. This figure also shows the sites, soil borings and wells that were registered into the GDB.

intercept different geological units (technogenic deposits, Quaternary alluvial deposits, paleogenic sediments of the Tertiary, saprolite and bedrock), there is no regional understanding of the lateral and vertical dimension of these units where they occur. Data interpolation from soil borings and wells, using IDW, resulted in the map of thickness of the sediments (Figure 5). The data suggest the occurrence of a structural control of the sediment thicknesses, which also explains the accentuated change in the Zavuvus creek path (Figure 1 and Figure 5) and the abrupt thickening of the sediments in the central portion of the study area.

Five geological cross-sections were prepared along the FIZ 131 to better understand the lateral and vertical extent of the lithological units (Figure 6), which is an automatic process once all data is organized in the GDB. In the example presented, the cross-sections were build crossing areas with higher amount of data, resulting in more reliable interpolation and the consolidation of aquifer geometry for hydrogeological conceptual models. Alluvial deposits and Paleogenic sediments were grouped into a single class, because in general there was no differentiation of the descriptions in the reports.

Two aquifer units occur in the area, the Sedimentary and the Crystalline [16]. The sedimentary aquifer system is an unconfined to semiconfined unit of primary porosity, which is very heterogeneous and anisotropic due to the occurrence of interbeded layers of sand and clay sediments of the Sao Paulo Basin [24]. The hydraulic conductivity data ranges from $10^{-9}$ to $10^{-3} \mathrm{~m} / \mathrm{s}$. In the FIZ 131, the distribution of hydraulic heads of the shallow aquifer indicates that the water table surface is similar to the one of the ground surface, indicating that the probable discharge zones of the shallow aquifer units are the Pinheiros river and the Poli and Zavuvus creeks (Figure 1). 


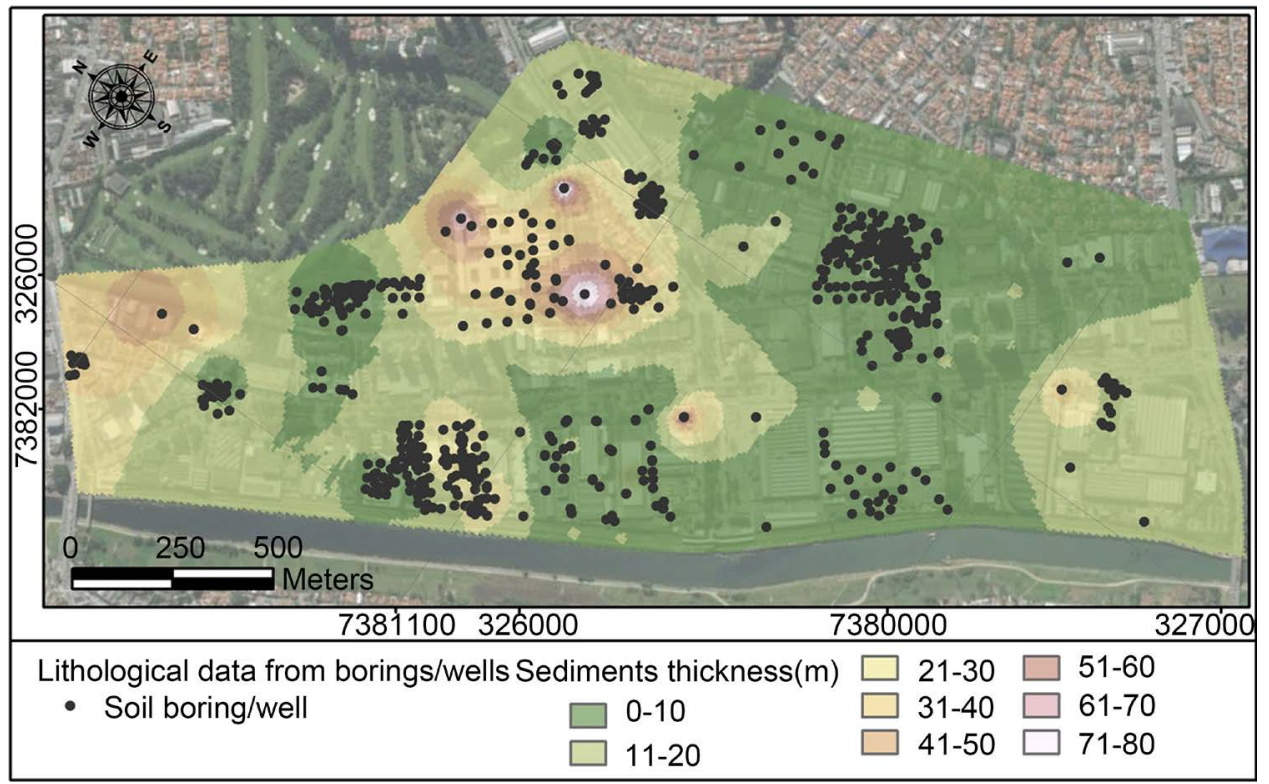

Figure 5. Sediments thicknesses at the FIZ 131 based on the soil borings and wells lithological data using the IDW interpolation method.

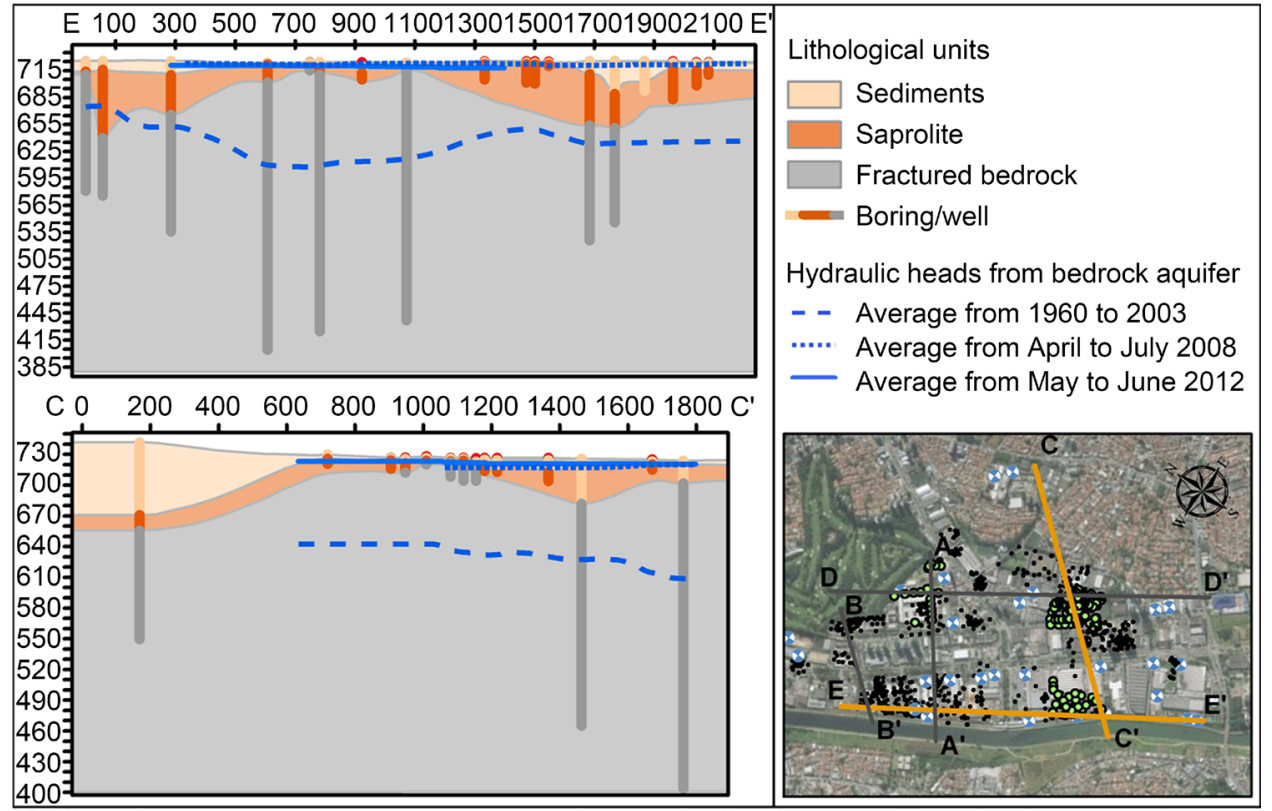

Figure 6. Cross sections $\mathrm{C}$ and $\mathrm{E}$ at the FIZ 131 based on soil borings and wells. Elevation on the $\mathrm{y}$ axis and distance in the $\mathrm{x}$ axis are expressed in meters.

The Crystalline Aquifer System is divided into two compartments with distinct behaviors, saprolite and fractured bedrock. The saprolite unit is dual porosity and very heterogeneous and anisotropic medium, where hydraulic conductivity values vary from $10^{-8}$ to $10^{-4} \mathrm{~m} / \mathrm{s}$, depending on the weathering degree of the parent rock [25]. This unit presents a lower hydraulic head relative to the upper sedimentary aquifer, indicating the existence of a vertical downward potential. Distribution of hydraulic heads indicates that discharge zones of this unit also comprise the Pinheiros River and the Poli and Zavuvus creeks. 
The bedrock aquifer is composed of migmatites, schists and gneisses. It is a fractured medium and water flows through the discontinuities of the rock. The hydraulic conductivity values in this system vary from $10^{-9}$ to $10^{-6} \mathrm{~m} / \mathrm{s}$. The activities of data acquisition resulted in the obtainment of a limited amount of information for this aquifer, which would allow the understanding of the current and past conditions of hydraulic heads of the deep fractured bedrock aquifer. However, it is known that after the interruption of the wells pumping in 2005, the hydraulic heads raised tens of meters, which resulted in an average hydraulic head of this unit close to the ones observed for the shallow sedimentary aquifer. A recent study has shown that there are two main groups of fractures with a higher probability of controlling water flow in the region: SE fractures of low dip and parallel to the rock foliation, and NW subvertical fractures [26].

\subsection{Spatial Distribution of Chlorinated Solvents in Groundwater}

In 2005, the environmental agency performed a regional groundwater sampling from dozens of supply wells (of up to 300 meters deep) and concentrations of chlorinated compounds above the potability standards were detected in most of them along the FIZ 131 area. Even after nearly ten years of this study, many areas with suspected or potential sources of contamination remain unknown, as many do not yet conducted environmental liability studies. On the other hand, in the 13 sites where the existence of source of contamination were identified, many rounds of environmental assessments were performed, although little progress was made in investigations of greater depths inside the saprolite and the deeper fractured bedrock aquifer units.

Chlorinated organics are present in the three aquifer levels at the FIZ 131, being the shallowest portion the most investigated unit and with the greatest extention of contamination. The contaminants occurring with higher frequency and intensity are the chlorinated ethene compounds, although the chlorinated methanes and ethanes are also present. The maps of chlorinated organics distribution in groundwater presented (Figure 7 to Figure 9) were drawn considering the data obtained from 2010 to 2012, which presents a good spatial coverage.

Chlorinated organics distribution on the sedimentary and saprolite aquifers indicate three major contamination focus, formed by at least two contaminated sites (Figure 7 and Figure 8). However, it is possible to notice distinct characteristics of solvents (presence of different parent and degradation products compounds) in neighboring contaminated sites. Concentration averages in the monitoring wells ranging from undetected to more than 90,000 $\mu \mathrm{g} / \mathrm{l}$ (sum of all chlorinated organics detected). Comparing the concentration maps for the sedimentary aquifer (Figure 7) and the areas with no information (Figure 4), there are too many gaps of information to delineate the impacted zone.

Almost half (56\%) of the monitoring wells presents filter and pre-filter sections longer than 2 meters, which can cause dilution of the samples. Even though chlorinated organics concentrations in the sedimentary aquifer were found to be higher than $1 \%$ of the solubility limit, in some cases concentrations of up to $10 \%$ of the 


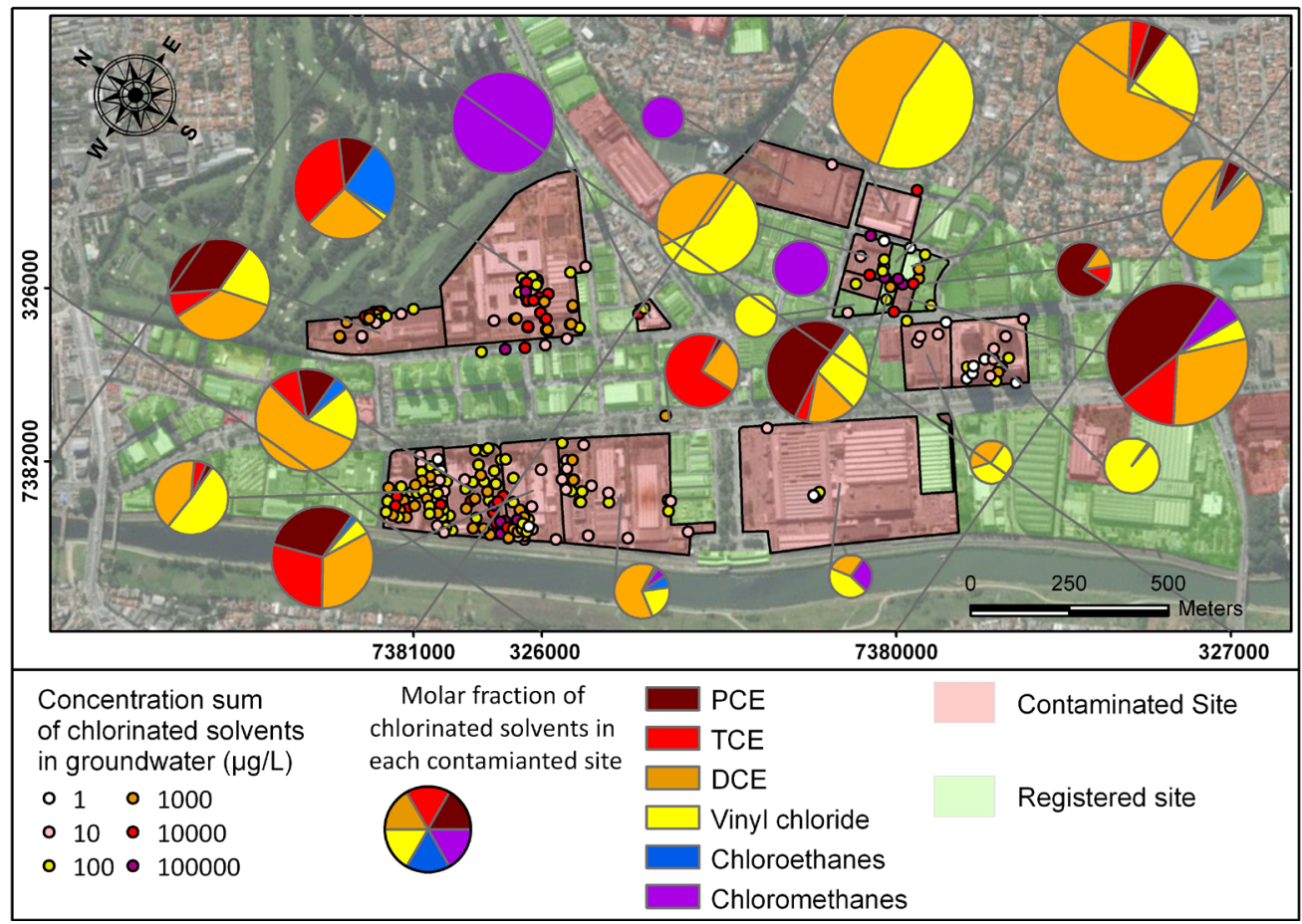

Figure 7. Chlorinated organics occurrence in the shallow sedimentary aquifer. Pie charts representing the average molar fraction of compounds per site and size associated to the log scale for the sum of total mass of solvents. Dots representing the average mass concentration of chlorinated solvents in the monitoring wells. Data available from 2010 and 2012.

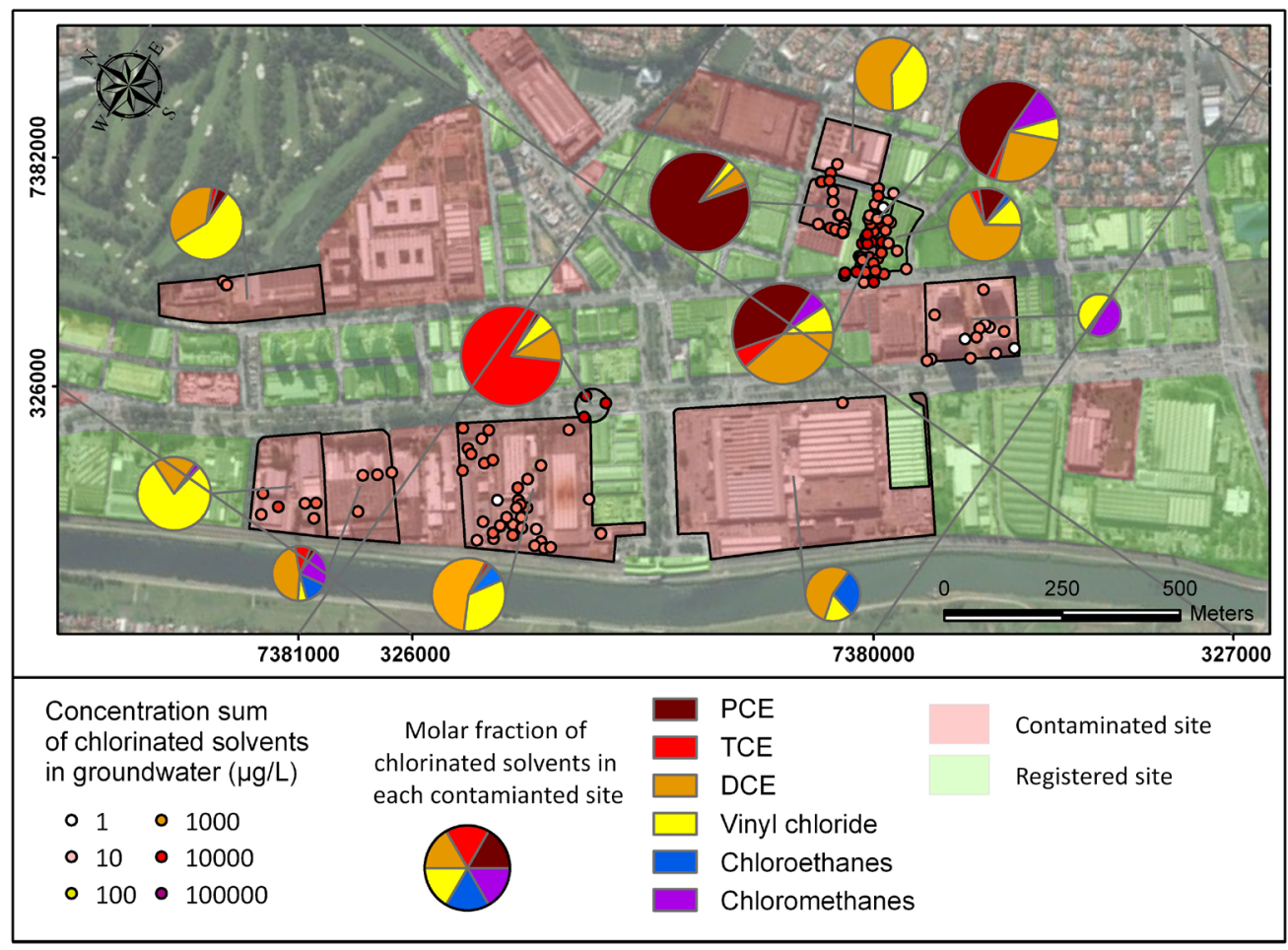

Figure 8. Chlorinated organics occurrence in the saprolite aquifer. Pie charts representing the average molar fraction of compounds per site and size associated to the log scale for the sum of total mass of solvents. Dots representing the average mass concentration of chlorinated solvents in the monitoring wells. Data available from 2010 and 2012. 
solubility limit were found. Concentrations of organic compounds greater than $1 \%$ of their effective solubility are indicative of the existence of NAPL [27]. Therefore, there is a strong evidence of active secondary sources of contamination in sites under management.

Regarding the bedrock aquifer contamination, only two groundwater sampling campaigns covering the entire network of supply wells are available. Both are campaigns carried out by the environmental agency in 2005. The time gap does not allow drawing a parallel between the current chemical data of monitoring wells and the bedrock aquifer campaign. Furthermore, sampling performed in 2005 was conducted directly at the tap of the well, which may have caused a mixture of water pumped from all the fractures and screens. Therefore, it is not possible to understand if the concentrations are related to shallower or deeper aquifer units.

The main compounds impacting the fractured bedrock aquifer also correspond to the chlorinated ethenes (Figure 9). The presence of parent compounds (PCE and TCE) varies from site to site, suggesting origins from different sources of contamination. Supply wells with higher concentrations of chlorinated organics, above $1000 \mu \mathrm{g} / \mathrm{l}$, were found close to the most impacted regions of the sedimentary aquifer. In some cases, the presence of father compounds did not match. This difference can be observed in some wells located in the southern portion of the area, where five neighboring wells present the detection of PCE concentra tions but no known source in the surrounding areas. Hence, it is not possible to stablish direct correlation between source area and concentration measured at a specific deep supply well.

One aspect to be considered in the interpretation of supply wells data is their

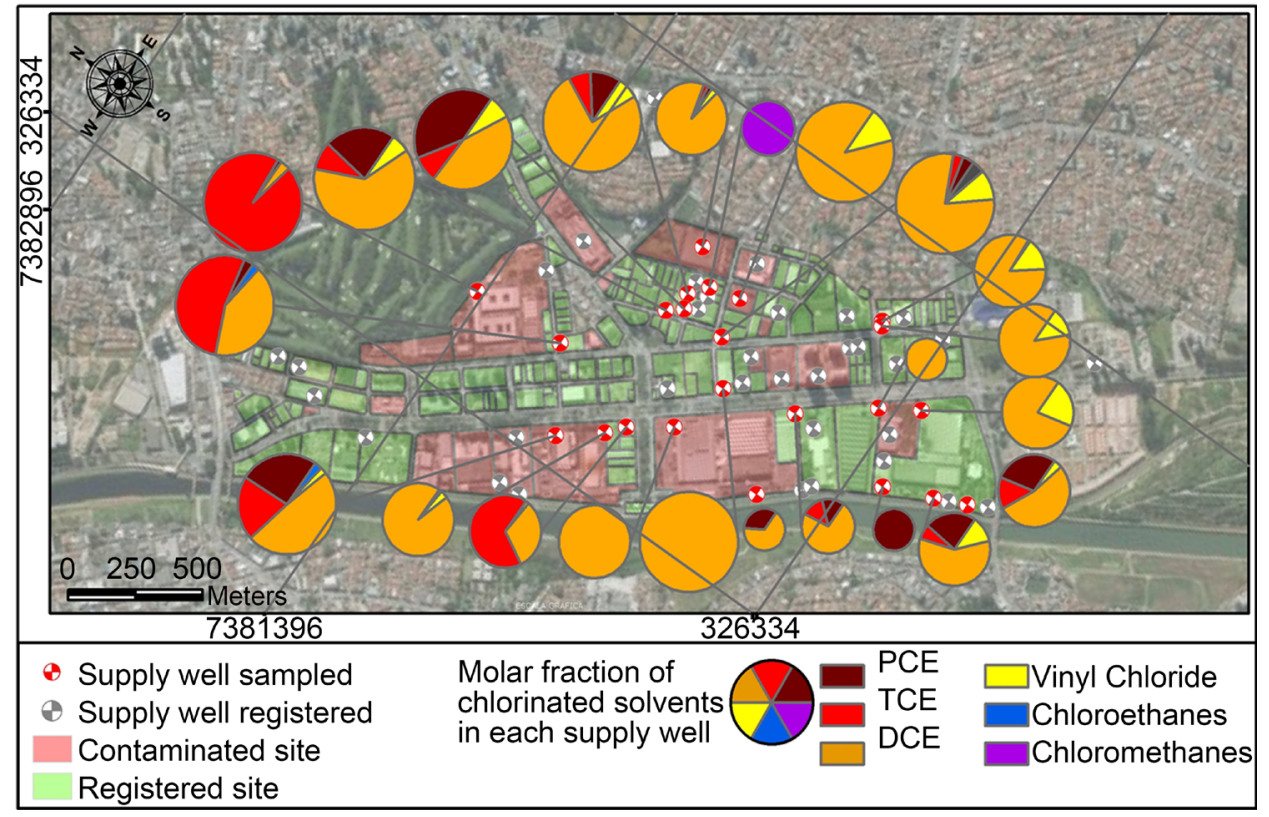

Figure 9. Chlorinated solvents presence in the supply wells in the monitoring campaign conducted by environmental agency in March 2005. Pie charts representing the molar fraction of the compounds per well and size associated to the log scale for the sum of total mass of solvents. 
influence on the transport of contaminants. One hypothesis is that the wells themselves were responsible for carrying contaminants into the bedrock aquifer [15]. On the other hand, the deepening of the contamination due to the higher density of the solvents and the existence of hydraulically active vertical fractures cannot be disregarded. Currently, the few chemical analysis data from supply wells indicate that concentrations are very low; however, this may be bias due to dilution effect. Due to the detection of these compounds in groundwater, the supply wells were abandoned, which caused the recovery of the hydraulic heads to levels similar to the ones observed in the shallow sedimentary aquifer (Figure 6).

Given the spatial distribution of the data and the existence of numerous potential areas with suspected contamination that have not been investigated, the current environmental panorama is out of date. The main problem is due to the inefficient way of managing information which impacts the progress of the site management. Site scale approach leads to the lack of organization, maldistribution and inability to correlate information, which hinders the process of megasite management.

Despite the evolution in site specific management, the extent of contamination and the best way to deal with the problem in the long term basis remains unknown. Meanwhile, the abandoned supply wells were not decommissioned and continue to be opened boreholes, which may represent a conduit that serves to transport contaminants from the shallow to the deeper aquifer units. Therefore, it is probable that contaminants are still migrating in the different aquifer units, which may increase the responsibility of the state to ensure the security of the population health. Human health risks may increase due to the consumption of groundwater from supply wells, since it is known the operation of illegal supply wells in the area of pumping restriction.

\subsection{Method for Participative Data Management}

The proposed method for data management allows the spatial visualization of essential information (Figure 10) for environmental management of megasites by regulatory agency. The biggest difficulty is the format of data available, hardcopies, PDF and spreadsheets, in some cases. The organization of the processes itself does not facilitate the integration of data. Studies are ordered by date of execution and old reports information gets lost in the pile of files. The systematization and importation of data proved to be a laborious activity, since these were found in numerous and voluminous folders (Table 1).

To deal with this challenge, a method for information management, that can be developed and applied to megasites in Sao Paulo state, was developed to faci litate processing and interpretation of the data (Figure 10). It is assumed that the environmental agency would be the administrator of the GDB system. So, it is part of their responsibilities the designing and maintenance of the GDB that will receive the data. It is also their responsibility the establishment of the format and the characteristics of the data that can enter the GDB, which allows the standardization and organization of the data. On the other hand, those responsible for the conta minated sites, as well as companies responsible for generating information (tech- 
nical managers, drilling companies, laboratories, among others) would be responsible for the data generated and inserted in the BDG.

Regulatory agencies can use the integrated database to support decisions and create policies more efficiently (Figure 11). They have direct and indirect impact in the GDB evolution. Direct by inserting data they produce into the GDB; indirect

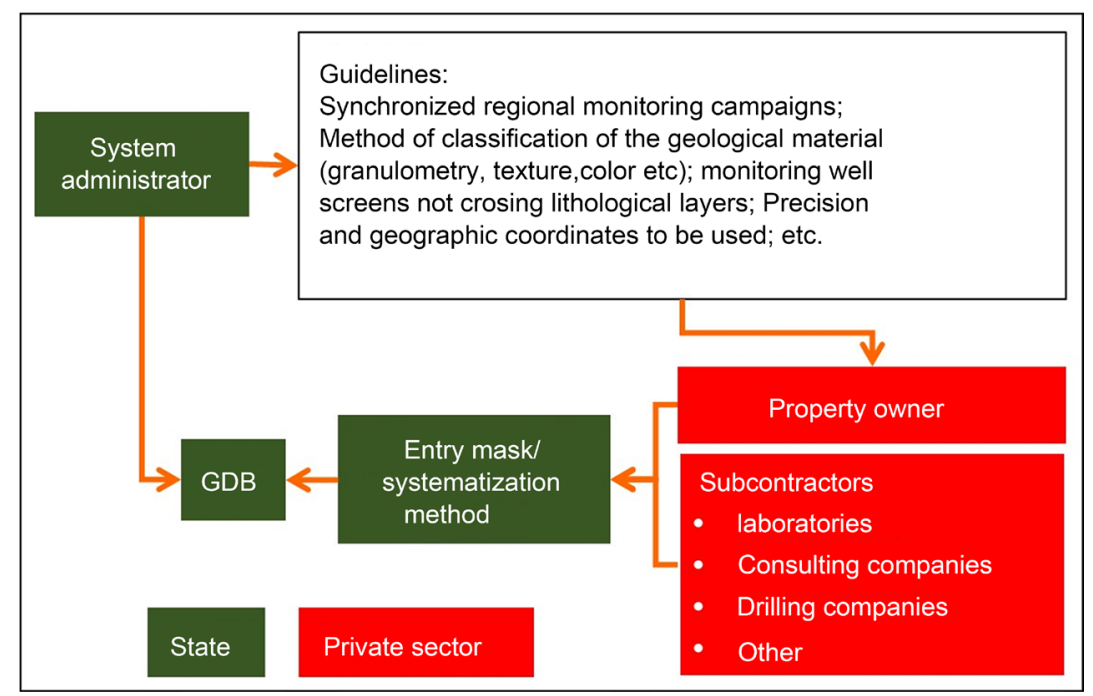

Figure 10. Proposed method for the integration of the environmental data for soil and groundwater contamination.

Table 1. Essential data to be inserted into the geodatabase organized by feature class. HGU refers to Hydrogeology Unit and COC to Compounds of Concern.

\begin{tabular}{|c|c|c|c|c|c|c|c|}
\hline $\begin{array}{l}\text { 1. Property } \\
\text { register }\end{array}$ & 2. Soil boring & $\begin{array}{c}\text { 3. Soil } \\
\text { characteristics }\end{array}$ & 5. Aquifer & 6. Well & $\begin{array}{l}\text { 7. Hydraulic } \\
\text { head }\end{array}$ & $\begin{array}{l}\text { 8. Hydraulic } \\
\text { parameters }\end{array}$ & $\begin{array}{l}\text { 9. Water } \\
\text { quality }\end{array}$ \\
\hline ID & ID & ID & ID & ID & ID & ID & ID \\
\hline address & $\begin{array}{l}\text { geographic } \\
\text { location and } \\
\text { elevation }\end{array}$ & Date & description & Date & Date & Date & Date \\
\hline $\begin{array}{l}\text { geographic } \\
\text { location }\end{array}$ & item 1 ID & collection method & $\mathrm{HGU}$ & $\begin{array}{l}\text { drill and } \\
\text { installation } \\
\text { diameter }\end{array}$ & $\begin{array}{l}\text { water level and } \\
\text { hydraulic head }\end{array}$ & type of test & $\begin{array}{l}\text { collection } \\
\text { method }\end{array}$ \\
\hline site history & depth interval & depth interval & $\begin{array}{c}\text { data } \\
\text { source }\end{array}$ & depth & $\begin{array}{l}\text { free phase } \\
\text { presence }\end{array}$ & result & parameter \\
\hline $\begin{array}{c}\text { pollutant } \\
\text { classification }\end{array}$ & lithological unit & Item $5 \mathrm{HGU}$ & coments & $\begin{array}{l}\text { screen, casing } \\
\text { and seal depth } \\
\text { interval }\end{array}$ & data source & $\begin{array}{l}\text { method of test and } \\
\text { interpretation }\end{array}$ & result \\
\hline $\begin{array}{c}\text { historical use or } \\
\text { activities related to } \\
\text { COC }\end{array}$ & $\begin{array}{c}\text { texture } \\
\text { description }\end{array}$ & $\begin{array}{l}\text { density, organic } \\
\text { matter content, } \\
\text { moisture }\end{array}$ & - & $\begin{array}{l}\text { top of casing } \\
\text { elevation }\end{array}$ & coments & data source & data source \\
\hline data source & granulometry & $\begin{array}{l}\text { grain size propor- } \\
\text { tion and others }\end{array}$ & - & well use & - & coments & coments \\
\hline coments & item $5 \mathrm{HGU}$ & $\begin{array}{l}\text { total and effective } \\
\text { porosity }\end{array}$ & - & current status & - & - & - \\
\hline - & $\begin{array}{l}\text { type (soil boring, } \\
\text { well etc.) }\end{array}$ & chemical data & - & item 5 ID & - & - & - \\
\hline- & data source & data source & - & data source & - & - & - \\
\hline- & coments & coments & - & coments & - & - & - \\
\hline
\end{tabular}


by stablishing guidelines for specific study areas and public policies regarding the environment and land use. This cyclic process can harmonize the communication between the agencies involved in the water resources management and effectiveness of their actions.

\section{Conclusions}

The proposed method based on GIS has demonstrated its usefulness for the management of megasites. Several limitations on the management of the FIZ 131 were identified in this study due to site-by-site approach used by the environmental agency: (1) contaminated sites are in different stages of investigation; (2) information is concentrated on the minority of the contaminated sites (21 sites), while most of the properties that used chlorinated solvents in the past are still not investigated (53 properties); (3) most of the available data from contaminated sites are from shallow investigations of the sedimentary aquifer, while investigations of the underneath saprolite and the fractured bedrock aquifer are exceptions; (4) groundwater campaign in restricted areas and shallow monitoring wells makes little contribu tion to the understanding of the megasite problem and is a waste of re-sources.

Overall, the adoption of this method would increase the productivity of environmental agency technicians, reduce the physical volumes of processes and increase the possibilities of managing contaminated areas in a more integrated way. Thus, many other areas like Jurubatuba may be better managed with re sources already available, benefiting not only civil society but also local economy through the increase in water supply and service. Therefore, the results will be the safeguard of the public health, the optimization of resources and the gradual improvement of groundwater quality.

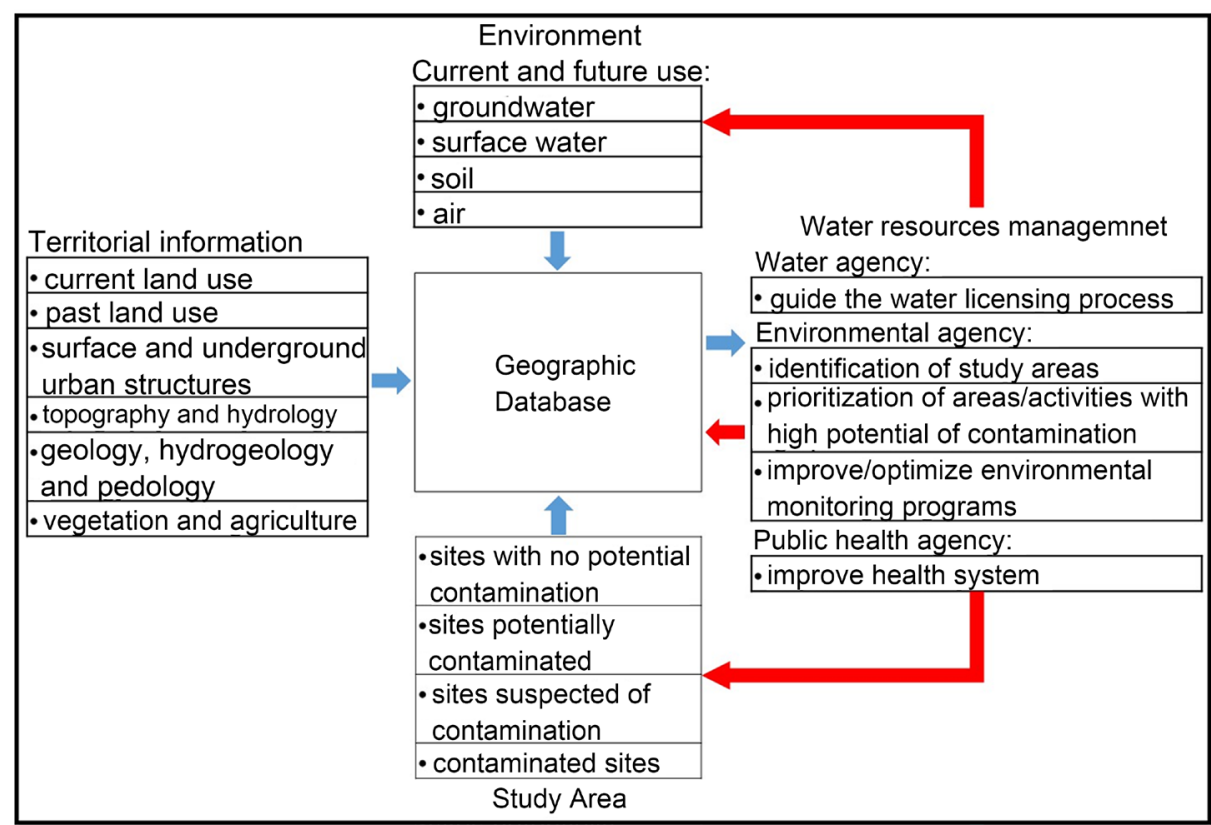

Figure 11. Application of the GDB for the management of water resources by the public agencies. 


\section{Acknowledgements}

We thank the environmental agency of Sao Paulo state, CETESB that facilitated the access to the data presented in reports of contaminated sites. We also thank FINEP (process 0110080800) for the project funding and FAPESP for providing scholarship (process 2012/11691-1). We also thank Professor Jun Shinohara for his support in database design and geoprocessing matters.

\section{References}

[1] Malina, G., Krupanek, J., Sievers, J., Grossmann, J., ter Meer, J. and Rijnaarts, H.H. (2006) Integrated Management Strategy for Complex Groundwater Contamination at a Megasite Scale. In: Twardowska, I., Allen, H.E., Häggblom, M.M. and Stefaniak, S., Eds., Soil and Water Pollution Monitoring, Protection and Remediation, Springer, Dordrecht, 567-577. https://doi.org/10.1007/978-1-4020-4728-2_37

[2] Schädler, S., Morio, M., Bartke, S. and Finkel, M. (2012) Integrated Planning and Spatial Evaluation of Megasite Remediation and Reuse Options. Journal of Contaminant Hydrology, 127, 88-100. https://doi.org/10.1016/j.jconhyd.2011.03.003

[3] CLARINET (2002) Review of Decision Support Tools for Contaminated Land Management: An Overview. http://www.commonforum.eu/publications_clarinet.asp

[4] Bardos, P. (2003) Sharing Experience in the Management of Megasites: Towards a Sustainable Approach in Land Management of Industrially Contaminated Sites. Report of the NICOLE Workshop, 29-31. http://www.nicole.org/uploadedfiles/NICOLE-Lille-October2003.pdf

[5] Carlon, C., Pizzol, L., Critto, A. and Marcomini, A. (2008) A Spatial Risk Assessment Methodology to Support Remediation of Contaminated Land. Environment International, 34, 397-411. https://doi.org/10.1016/j.envint.2007.09.009

[6] Schädler, S., Morio, M., Finkel, M. and Trefry, M.G. (2008) Land-Use Related Cost Estimates for Contaminated Site Development: Consequences of Uncertainty for Planning and Investment Decisions. Proceedings Groundwater Quality 2007 Conference, Fremantle, 2-7 December 2007, 539-546.

[7] Jamin, P., Dollé, F., Chisala, B., Orban, P., Popescu, I.C., Herivaux, C., Dassargues, A. and Brouyère, S. (2012) A Regional Flux-Based Risk Assessment Approach for Multiple Contaminated Sites on Groundwater Bodies. Journal of Contaminant Hydrology, 127, 65-75. https://doi.org/10.1016/j.jconhyd.2011.07.001

[8] Vega, A., Argus, R., Stockton, T., Black, P., Black, K. and Stiber, N. (2009) SMARTe: An MCDA Approach to Revitalize Communities and Restore the Environment. In: Marcomini, A., Suter, G.W. II and Critto, A., Eds., Decision Support Systems for Risk-Based Management of Contaminated Sites, Springer, New York, 1-26. https://doi.org/10.1007/978-0-387-09722-0_9

[9] Sullivan, T., Yatsalo, B., Grebenkov, A. and Linkov, I. (2009) Decision Evaluation for Complex Risk Network Systems (DECERNS) Software Tool. In: Marcomini, A., Suter, G.W. II and Critto, A., Eds., Decision Support Systems for Risk-Based Management of Contaminated Sites, Springer, New York, 1-18.

https://doi.org/10.1007/978-0-387-09722-0_12

[10] Ascough, J.C., Maier, H.R., Ravalico, J.K. and Strudley, M.W. (2008) Future Research Challenges for Incorporation of Uncertainty in Environmental and Ecological Decision-Making. Ecological Modelling, 219, 383-399. https://doi.org/10.1016/j.ecolmodel.2008.07.015

[11] Malczewski, J. (2006) GIS-Based Multicriteria Decision Analysis: A Survey of the Literature. International Journal of Geographical Information Science, 20, 703-726. 
https://doi.org/10.1080/13658810600661508

[12] Morio, M., Finkel, M., Schädler, S., Hartmuth, G., Rügner, H. and Trefry, M.G. (2008) Improving Mega-Site Revitalisation Strategies by Trading off Benefits from Future Land Use and Clean-Up Costs. Proceedings Groundwater Quality 2007 Conference, Fremantle, 2-7 December 2007, 555-562.

[13] SAO PAULO (2009) Projeto Jurubatuba: Restrição e controle de uso de água subterrânea. Secretaria de Estado de Saneamento e Recursos Hídricos, Departamento de Águas e Energia Elétrica; Secretaria de Estado do Meio Ambiente, Instituto Geológico. DAEE/IG, Sao Paulo, 109.

[14] CETESB (2015) Áreas Contaminadas Críticas. http://www.cetesb.sp.gov.br/

[15] L'Apiccirella, E.S. (2009) Contaminação e Áreas de Restrição de Uso de Água Subterrânea no Entorno do Canal Jurubatuba em Sao Paulo-SP. MSc. Thesis, University of Sao Paulo, Sao Paulo.

[16] Hirata, R.C. and Ferreira, L.M. (2008) Os aqüíferos da Bacia Hidrográfica do Alto Tietê: Disponibilidade hídrica e vulnerabilidade à poluição. Brazilian Journal of Geology, 31, 43-50.

[17] CBH-AT-COMITÊ DA BACIA HIDROGRÁFICA DO ALTO TIETÊ (2011) Áreas de restrição e controle para a captação e uso das águas subterrâneas no município de Sao Paulo, na região de Jurubatuba. Sao Paulo.

[18] Strassberg, G., Jones, N.L. and Maidment, D.R. (2011) Arc Hydro Groundwater. Esri Press, Redlands, California.

[19] ESRI (2013) Knowledge Base-Technical Articles: Data Models. http://downloads2.esri.com/support/TechArticles/Groundwater_Data_Model.pdf

[20] Jacob, A.M., Castro, G. and Miyashiro, N.J. (2012) Aplicação de método geoelétrico para caracterização geológica estratigráfica e estrutural. Thesis, SENAC, Sao Paulo.

[21] Pereira, E.V. and Sartini, R.P. (2007) Gerenciamento de Áreas Contaminadas na Região do Jurubatuba. Thesis, SENAC, Sao Paulo.

[22] CETESB (2014) Relação de Áreas Contaminadas e Reabilitadas. http://www.cetesb.sp.gov.br/areas-contaminadas/rela\%E7\%F5es-de-\%E1\%A1reas-c ontaminadas/4-rac

[23] US Soil Survey Staff (1993) Soil Survey Manual. United States Department of Agriculture, Washington DC.

[24] Bertolo, R.A. (1996) Relações entre rios e o aqüífero sedimentar da Bacia de Sao Paulo em área de exploração intensiva de água subterrânea. PhD Dissertation, University of Sao Paulo, Sao Paulo.

[25] Rebouças, A. (1992) Condições de uso e proteção das águas subterrâneas. Proceedings Problemas Geológicos e Geotécnicos na RMSP, ABAS/ABGE/SBG-SP, Sao Paulo, 77-87.

[26] Fernandes, A.J., Fiume, B., Bertolo, R. and Hirata, R.C.A. (2016) Modelo geométrico de fraturas e análise da tectônica rúptil aplicados ao estudo do fluxo do aquífero cristalino, Sao Paulo (SP). Geologia USP, 16, 71-88. https://doi.org/10.11606/issn.2316-9095.v16i3p71-88

[27] Pankow, J.F. and Cherry, J.A. (1996) Dense Chlorinated Solvents and Other DNAPLs in Groundwater: History, Behavior, and Remediation. Waterloo Press, Ontario. 
Submit or recommend next manuscript to SCIRP and we will provide best service for you:

Accepting pre-submission inquiries through Email, Facebook, LinkedIn, Twitter, etc. A wide selection of journals (inclusive of 9 subjects, more than 200 journals)

Providing 24-hour high-quality service

User-friendly online submission system

Fair and swift peer-review system

Efficient typesetting and proofreading procedure

Display of the result of downloads and visits, as well as the number of cited articles Maximum dissemination of your research work

Submit your manuscript at: http://papersubmission.scirp.org/

Or contact jwarp@scirp.org 